


\title{
Beiträge zur Messung und empirischen Analyse des Einflusses von Steuerasymmetrien auf Investitionsentscheidungen
}

Essays on the measurement and empirical analysis of the impact of tax asymmetries on investment decisions

\author{
Dissertation \\ zur Erlangung des Doktorgrades \\ der Wirtschaftswissenschaftlichen Fakultät \\ der Georg-August-Universität Göttingen
}

vorgelegt von

Sebastian Bause

geboren in Göttingen

Göttingen, 2017 


\section{Betreuungsausschuss}

Erstbetreuer: $\quad$ Prof. Dr. Andreas Oestreicher

Weitere Betreuer: Prof. Dr. Jörg-Markus Hitz

Prof. Dr. Robert Schwager

Tag der mündlichen Prüfung: 19. Februar 2018 


\section{Inhaltsübersicht}

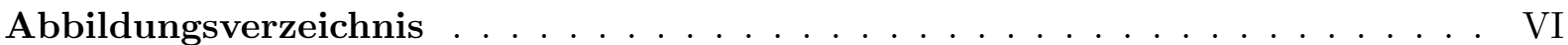

Tabellenverzeichnis $\ldots \ldots \ldots \ldots \ldots \ldots \ldots \ldots \ldots \ldots \ldots$ VIII

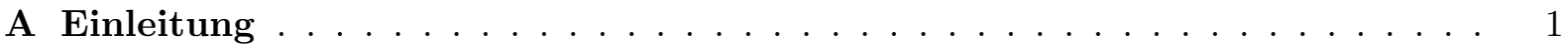

B Zur Diskussion der Besteuerung von Wertpapier-Publikumsfonds in

Deutschland . . . . . . . . . . . . . . . . . . . . . 6

1 Motivation und Zielsetzung der Untersuchung . . . . . . . . . . . . . 7

2 Besteuerung der Direktanlage . . . . . . . . . . . . . . . . 8

3 Besteuerung der Fondsanlage nach geltendem Recht und dem Reformentwurf . . 11

4 Auswirkungen einer Umsetzung des Reformvorschlags auf die effektive Steuerbelastung von natürlichen Personen . . . . . . . . . . . . . . . 18

$5 \quad$ Zusammenfassung und Ausblick . . . . . . . . . . . . . . . . 35

C Location of intra-EU greenfield FDI: Do tax loss offset restrictions matter? 37

$1 \quad$ Introduction . . . . . . . . . . . . . . . . . . . . . . . 38

2 MNE location choice and asymmetric taxation f . . . . . . . . . . 40

3 Empirical methodology . . . . . . . . . . . . . . . . . . . . . 47

$4 \quad$ Data and variables . . . . . . . . . . . . . . . . . . 48

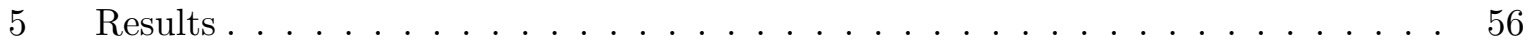

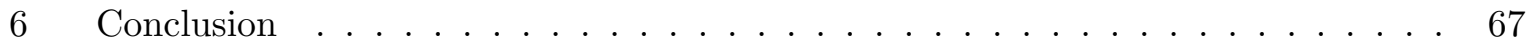

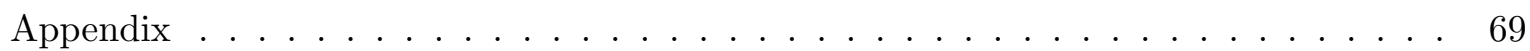

D The sensitivity of simulated marginal tax rates to specific tax rules $\ldots \ldots 76$

$1 \quad$ Introduction . . . . . . . . . . . . . . . . . . . . . 77

2 Review on existing approaches to simulating marginal tax rates and related

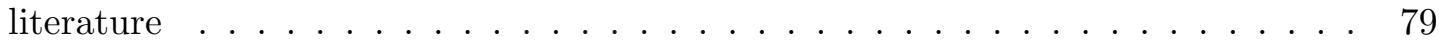

3 Discussion of selected aspects regarding the determination of simulated marginal

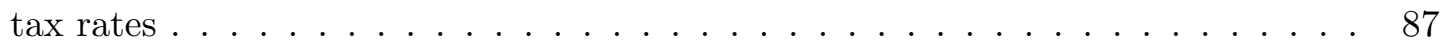

4 Simulating marginal tax rates of European companies . . . . . . . . . . . . . 92

$5 \quad$ Evaluation . . . . . . . . . . . . . . . . . . . 116 


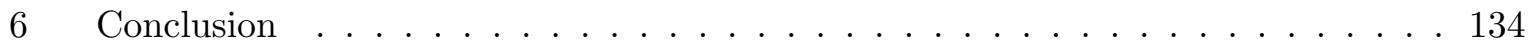

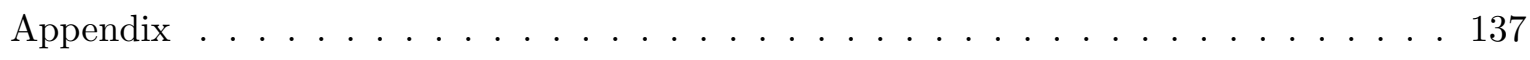

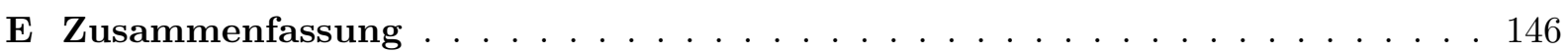

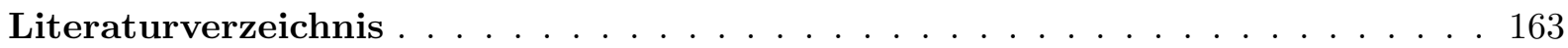




\section{Inhaltsverzeichnis}

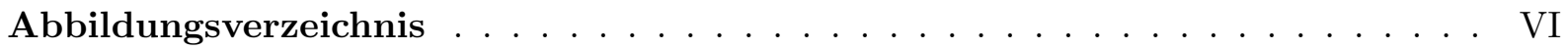

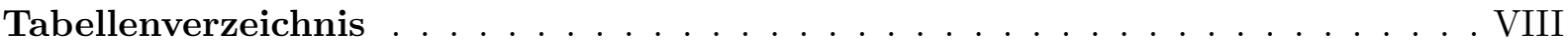

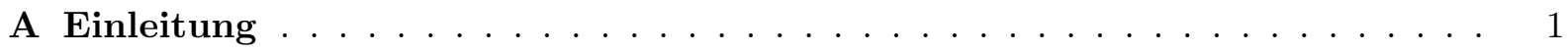

B Zur Diskussion der Besteuerung von Wertpapier-Publikumsfonds in

Deutschland . . . . . . . . . . . . . . . . . . . . . 6

1 Motivation und Zielsetzung der Untersuchung . . . . . . . . . . . . . . . 7

2 Besteuerung der Direktanlage . . . . . . . . . . . . . . . . . 8

2.1 Abgrenzung des Untersuchungsgegenstands . . . . . . . . . . . . . . . 8

2.2 Wertpapiere im Privatvermögen . . . . . . . . . . . . . . . . . 9

2.3 Wertpapiere im Betriebsvermögen . . . . . . . . . . . . . . . . . . 10

3 Besteuerung der Fondsanlage nach geltendem Recht und dem Reformentwurf . . . . 11

3.1 Abgrenzung des Untersuchungsgegenstands . . . . . . . . . . . . . . . . 11

3.2 Besteuerung des Investmentfonds $\ldots \ldots \ldots \ldots$

3.2.1 Steuerrechtssubjektivität und eigenständige Steuerpflicht von

Investmentfonds . . . . . . . . . . . . . . . . . . . . 13

3.2.2 Investmentsteuerliche Sondervorschriften zur Ertragsermittlung auf

Fondsebene ............................. 14

3.3 Besteuerung des Fondsanlegers . . . . . . . . . . . . . . . 15

3.3.1 Steuerbarkeit und Zuordnung der Einkünfte aus Fondsanteilen . . . . . . . 15

3.3 .2 Fondsanteile im Privatvermögen . . . . . . . . . . . . . . . 16

3.3 .3 Fondsanteile im Betriebsvermögen . . . . . . . . . . . . . . . . . 18

4 Auswirkungen einer Umsetzung des Reformvorschlags auf die effektive

Steuerbelastung von natürlichen Personen . . . . . . . . . . . . . . . . 18

4.1 Berechnungsmethodik und Modellannahmen . . . . . . . . . . . . . 18

4.2 Relative steuerliche Vorteilhaftigkeit zwischen Direktanlage und Fondsanlage nach geltendem Recht . . . . . . . . . . . . . . . . . . 22

4.2 .1 Kapitalanlage im Privatvermögen . . . . . . . . . . . . . . . . . . 22 
4.2 .2 Kapitalanlage im Betriebsvermögen . . . . . . . . . . . . . . . . . . 23

4.2 .3 Zwischenergebnis . . . . . . . . . . . . . . . . 26

4.3 Reformbedingte Auswirkungen auf die relative steuerliche Vorteilhaftigkeit zwischen Direktanlage und Fondsanlage . . . . . . . . . . . . . . . . . 26

4.3.1 Kapitalanlage im Privatvermögen . . . . . . . . . . . . . . . . . 26

4.3.2 Kapitalanlage im Betriebsvermögen . . . . . . . . . . . . . . . . . . . . . . 29

4.3 .3 Zwischenergebnis . . . . . . . . . . . . . . . . . 30

4.4 Reformbedingte Auswirkungen auf die Steuerbelastung von Fondsanlagen . . . . 31

4.5 Mögliche Auswirkungen auf das Steueraufkommen . . . . . . . . . . . . . . 33

5 Zusammenfassung und Ausblick . . . . . . . . . . . . . . . . . 35

C Location of intra-EU greenfield FDI: Do tax loss offset restrictions matter? 37

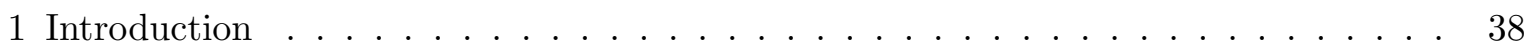

2 MNE location choice and asymmetric taxation . . . . . . . . . . . . 40

2.1 The OLI framework of MNE activity . . . . . . . . . . . . . 40

2.2 Tax loss offset limitations as location disadvantages . . . . . . . . . . . . 41

3 Empirical methodology $\ldots \ldots \ldots \ldots \ldots$. . . . . . . . . . . . . 47

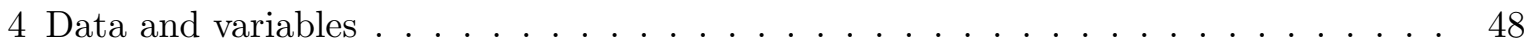

4.1 Sample selection . . . . . . . . . . . . . . . . . . . . . . 48

4.2 Proxy variables for tax burden and loss exposure $\ldots \ldots \ldots \ldots$. . . . . . 52

4.3 Control variables . . . . . . . . . . . . . . . . . . 54

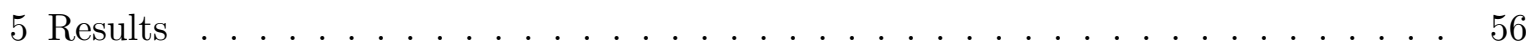

5.1 Baseline analysis . . . . . . . . . . . . . . . 56

5.2 Sensitivity analyses . . . . . . . . . . . . . . . . . 62

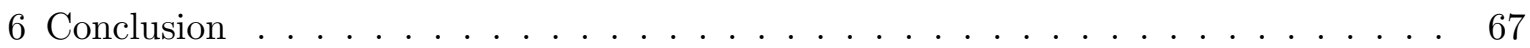

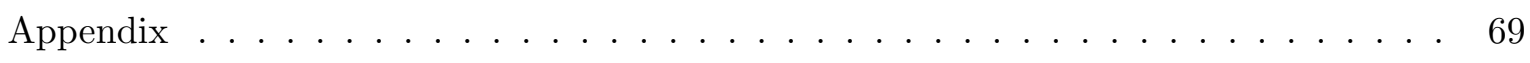

D The sensitivity of simulated marginal tax rates to specific tax rules $\ldots \ldots$

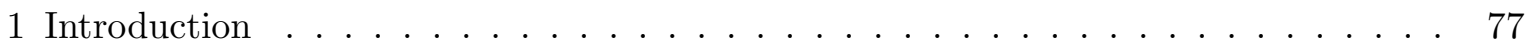

2 Review on existing approaches to simulating marginal tax rates and related literature 79

2.1 Random walk approach . . . . . . . . . . . . . . . . . . 79

2.2 Non-parametric bin approach $\ldots \ldots \ldots \ldots \ldots \ldots$

2.3 First-order autoregressive approach $\ldots \ldots \ldots \ldots$ 
3 Discussion of selected aspects regarding the determination of simulated marginal

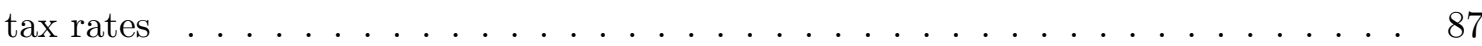

3.1 Approach to simulating future income . . . . . . . . . . . . . 87

3.2 Use of consolidated financial statement data . . . . . . . . . . . . . . . . 89

3.3 Determination of taxable income . . . . . . . . . . . . . . . . 90

4 Simulating marginal tax rates of European companies . . . . . . . . . . . . . . . 92

4.1 General considerations . . . . . . . . . . . . . . . . . . . 92

4.2 Data collection and simulation procedure . . . . . . . . . . . . . 94

4.2 .1 Sample selection . . . . . . . . . . . . . . . . . . . . 94

4.2 .2 Parameter estimation . . . . . . . . . . . . . . . . . 95

4.2 .3 Simulation of pre-tax book income . . . . . . . . . . . . . . . 97

4.3 Coding of tax rules $\ldots \ldots \ldots \ldots \ldots \ldots \ldots$

4.3.1 Tax treatment of dividend income . . . . . . . . . . . . . . . . 100

4.3 .2 Group taxation . . . . . . . . . . . . . . . . . . . 103

4.3.3 Thin capitalisation and interest capping rules . . . . . . . . . . 106

4.3.3.1 Overview . . . . . . . . . . . . . . 106

4.3.3.2 Thin capitalisation rules . . . . . . . . . . . . . . . 107

4.3.3.3 Interest capping rules . . . . . . . . . . . . . . . . . . 109

4.3.4 Notional interest deduction . . . . . . . . . . . . . . . . . 112

4.3 .5 Inter-period tax loss offset $\ldots \ldots \ldots \ldots$. . . . . . . . . . 114

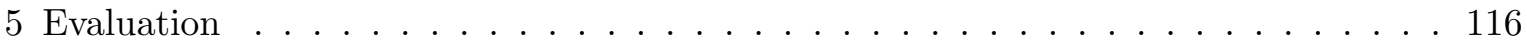

5.1 Descriptive statistics . . . . . . . . . . . . . . . 116

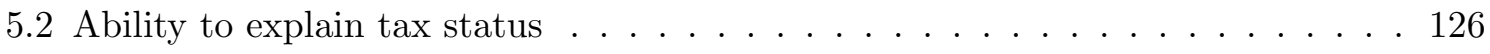

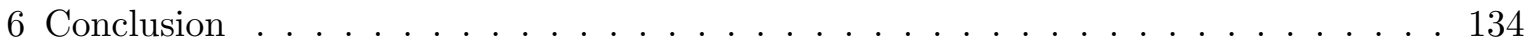

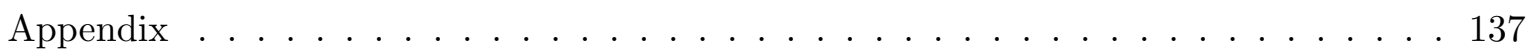

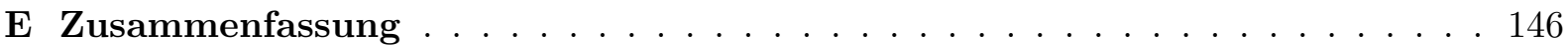

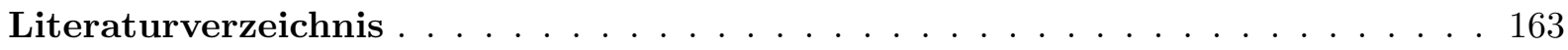




\section{Abbildungsverzeichnis}

B.1 Effektive Steuerbelastungen von Direkt- und Fondsanlage im Privatvermögen nach geltendem Recht . . . . . . . . . . . . . . . . . 23

B.2 Effektive Steuerbelastungen von Direkt- und Fondsanlage im Betriebsvermögen nach geltendem Recht $($ Szenario 1$) \ldots \ldots \ldots \ldots$. . . . . . . . . . 25

B.3 Effektive Steuerbelastungen von Direkt- und Fondsanlage im Betriebsvermögen nach geltendem Recht $($ Szenario 2$) \ldots \ldots \ldots \ldots$

B.4 Effektive Steuerbelastungen von Direkt- und Fondsanlage im Privatvermögen unter dem Reformszenario . . . . . . . . . . . . . . . . . . . . . 28

B.5 Effektive Steuerbelastung von Direkt- und Fondsanlage im Betriebsvermögen unter dem Reformszenario (Szenario 1) . . . . . . . . . . . . . . . 30

B.6 Effektive Steuerbelastung von Direkt- und Fondsanlage im Betriebsvermögen unter dem Reformszenario (Szenario 2) f . . . . . . . . . . . . . . . 31

B.7 Reformbedingte Belastungsdifferenzen der Fondsanlage im Privatvermögen . . 32

B.8 Reformbedingte Belastungsdifferenzen der Fondsanlage im Betriebsvermögen . . 33

C.1 Ratio of U.S. corporate tax losses by firm age . . . . . . . . . . . . . . . . 42

C.2 Distribution of subsidiary establishments in baseline sample over time . . . . . . 51

C.3 Marginal effect of $\mathrm{LCB}=1$ year and $\mathrm{LCB}>1$ year on location probability as LRI changes . . . . . . . . . . . . . . . . . . . . . . 59

C.4 Marginal effect of LCF $\leq 5$ years and LCF $>5$ years on location probability as LRI changes . . . . . . . . . . . . . . . . . . . 61

C.5 Marginal effect of MINTAX on location probability as LRI changes . . . . . . 61

C.6 Marginal effect of $\mathrm{LCB}=1$ year and $\mathrm{LCB}>1$ year on location probability as DSL changes . . . . . . . . . . . . . . . . . . . . . 64

C.7 Marginal effect of LCF $\leq 5$ years and $\mathrm{LCF}>5$ years on location probability as DSL changes . . . . . . . . . . . . . . . . . . . . . . 65

C.8 Marginal effect of MINTAX on location probability as DSL changes . . . . . . 65 
C.9 Marginal effect of $\mathrm{LCB}=1$ year and $\mathrm{LCB}>1$ year on location probability as LRI changes-EATR in place of STR . . . . . . . . . . . . . . . 69

C.10 Marginal effect of LCF $\leq 5$ years and LCF $>5$ years on location probability as LRI changes-EATR in place of STR . . . . . . . . . . . . . . . . . 69

C.11 Marginal effect of MINTAX on location probability as LRI changes-EATR in

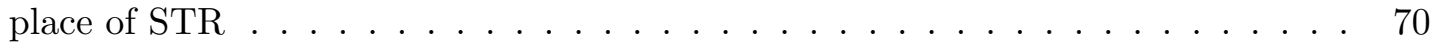

C.12 Marginal effect of $\mathrm{LCB}=1$ year and $\mathrm{LCB}>1$ year on location probability as LRI changes-Excluding intermediate companies . . . . . . . . . . . . . . 70

C.13 Marginal effect of $\mathrm{LCF} \leq 5$ years and $\mathrm{LCF}>5$ years on location probability as LRI changes -Excluding intermediate companies . . . . . . . . . . . . . . . 71

C.14 Marginal effect of MINTAX on location probability as LRI changes - Excluding intermediate companies . . . . . . . . . . . . . . . . . 71

C.15 Marginal effect of $\mathrm{LCB}=1$ year and $\mathrm{LCB}>1$ year on location probability as LRI changes - Excluding FDI between 2007 and 2009 . . . . . . . . . . 72

C.16 Marginal effect of $\mathrm{LCF} \leq 5$ years and $\mathrm{LCF}>5$ years on location probability as LRI changes-Excluding FDI between 2007 and 2009 . . . . . . . . . . 72

C.17 Marginal effect of MINTAX on location probability as LRI changes-Excluding

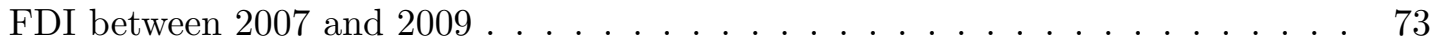

C.18 Marginal effect of $\mathrm{LCB}=1$ year and $\mathrm{LCB}>1$ year on location probability as LRI changes-Excluding FDI from DE/GB/LU . . . . . . . . . . . . . . 73

C.19 Marginal effect of $\mathrm{LCF} \leq 5$ years and $\mathrm{LCF}>5$ years on location probability as LRI changes-Excluding FDI from DE/GB/LU . . . . . . . . . . . . . . 74

C.20 Marginal effect of MINTAX on location probability as LRI changes-Excluding FDI from $\mathrm{DE} / \mathrm{GB} / \mathrm{LU} \ldots \ldots \ldots \ldots \ldots$. . . . . . . . . . . . . . . 74

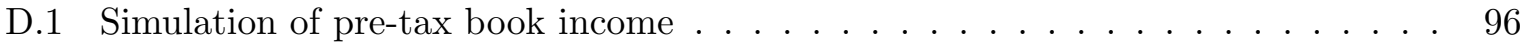

D.2 Distribution of simulated marginal tax rates f . . . . . . . . . . . . . . 123 


\section{Tabellenverzeichnis}

B.1 Untersuchte Fallkonstellationen . . . . . . . . . . . . . . . . . . . . . 20

B.2 Zusammensetzung der Gesamtrenditen . . . . . . . . . . . . . . . . . . 21

B.3 Mittelanlage inländischer Publikumsfonds . . . . . . . . . . . . . . . . 34

B.4 Reformbedingte Belastungsdifferenzen, aufgegliedert nach Ausschüttungsverhalten 34

C.1 Inter-period tax loss offset rules in the EU 28 (excluding Estonia) between 2002

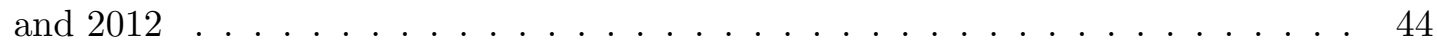

C.2 Sample selection . . . . . . . . . . . . . . . . . . . . . . 49

C.3 Breakdown of subsidiary establishments in baseline sample by home and host

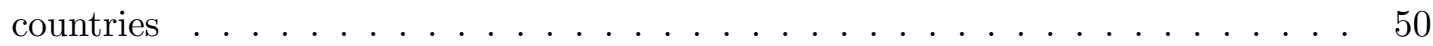

C.4 Breakdown of subsidiary establishments in baseline sample by NACE Rev. 2

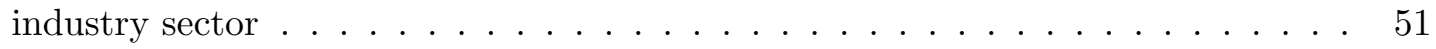

C.5 Descriptive statistics and variables measurement f . . . . . . . . . . 55

C.6 Location probability and tax loss offset provisions-baseline regression . . . . . 57

C.7 Location probability and tax loss offset provisions - sensitivity analyses _ . . . 63

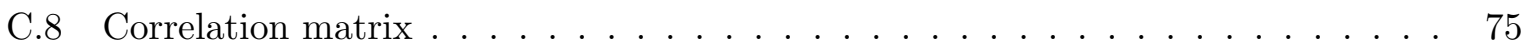

D.1 Data collection process summarised by country . . . . . . . . . . . 95

D.2 Composition of simulation panels summarised by country and year . . . . . . . 98

D.3 Definition of simulated marginal tax rates . . . . . . . . . . . . 117

D.4 Summary statistics by simulation year . . . . . . . . . . . . . . 118

D.5 Pearson correlation matrix _ . . . . . . . . . . . . . . . . 125

D.6 Composition of regression panels . . . . . . . . . . . . . . . 127

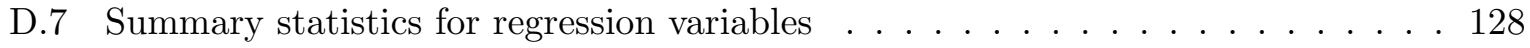

D.8 Pearson correlation matrix of regression variables . . . . . . . . . . . . . 130

D.9 Predictive ability of simulated marginal tax rates: Regression results . . . . . . 131

D.10 Predictive ability of simulated marginal tax rates based on estimated taxable income: Composition of regression panel . . . . . . . . . . . . . . . 133 
D.11 Predictive ability of simulated marginal tax rates based on estimated taxable income: Regression results . . . . . . . . . . . . . . . . . . . . . 134

D.12 Implementation of the EU Parent Subsidiary Directive in the EU-27 (excluding Estonia) during $2003-2013$. . . . . . . . . . . . . . . . . . . 137

D.13 Inter-company loss relief under domestic group taxation systems in the EU-27 (excluding Estonia) during $2003-2013$. . . . . . . . . . . . . . . . . 138

D.15 Thin capitalisation and interest capping rules in the EU-27 (excluding Estonia) during $2003-2013 \ldots \ldots \ldots \ldots \ldots$

D.14 Notional interest deduction regimes in the EU-27 (excluding Estonia) during

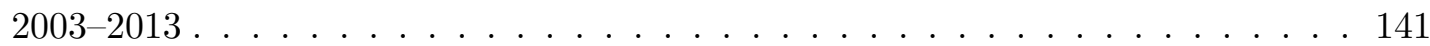

D.16 Inter-period tax loss offset in the EU-27 (excluding Estonia) during 2003-2013 142

D.17 Statutory corporate income tax rates in the EU-27 (excluding Estonia) during

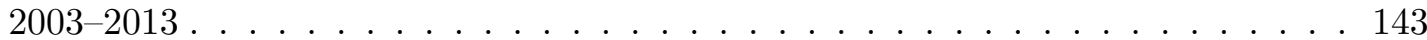




\section{Kapitel A}

\section{Einleitung}

Ein rational handelnder, nutzenmaximierender Entscheider wird Steuerzahlungen in sein Entscheidungskalkül über die Wahl zwischen - steuerlich relevanten-Handlungsalternativen einbeziehen, da Steuern zum einen regelmäßig das finanzielle Ergebnis der Handlungsalternativen mindern, sie zum anderen aber auch die Vorteilhaftigkeitsrangfolge konkurrierender Handlungsalternativen beeinflussen und mithin Entscheidungswirkungen auslösen können (Scheffler, 2013, S. 3). Diesbezüglich ist aus volkswirtschaftlicher Sicht von Bedeutung, dass mangelnde Steuerneutralität Verhaltensänderungen der Steuerpflichtigen erwarten lässt, die zu einem ineffizienten Einsatz knapper Ressourcen führen können. Aus einzelwirtschaftlicher Sicht sind aneutrale Steuersysteme abzulehnen, da sie zusätzlichen Planungsaufwand für die Steuerpflichtigen bedingen und wettbewerbsverzerrende Wirkung entfalten (Schreiber, 2012, S. 603 f.).

Zur Bestimmung der effektiven, wirtschaftlichen Steuerbelastung einer Handlungsalternative genügt es grundsätzlich nicht, lediglich den tariflichen Steuersatz als Maßgröße heranzuziehen. Vielmehr ist zusätzlich von Bedeutung, auf welche Bemessungsgrundlage der tarifliche Steuersatz Anwendung findet. Eine am rechtlichen Tarif gemessen relativ hoch besteuerte Alternative kann effektiv relativ niedrig besteuert sein, wenn die zugrunde gelegte Bemessungsgrundlage eng gefasst ist. Umgekehrt gilt, dass eine breite steuerliche Bemessungsgrundlage eine, gemessen am rechtlichen Steuersatz, relativ hohe effektive Steuerbelastung impliziert. Gerade im internationalen Vergleich lässt sich eine Vielzahl teils sehr spezieller Vorschriften identifizieren, die auf den Umfang der Bemessungsgrundlage einwirken. Aufgrund ihrer Relevanz besonders hervorzuheben sind in diesem Zusammenhang die Vorschriften zur Vorratsbewertung, zur Abschreibung von Anlagevermögen, zur intertemporalen Verlustverrechnung und zur Behandlung von Beteiligungserträgen und Zinsen. Kennt das Steuerrecht eines Landes besondere Vorschriften zur Besteuerung von konzernverbundenen Unternehmen, setzt eine akkurate Beurteilung der steuerlichen Konsequenzen einer Entscheidung im Konzern ferner den Einbezug von Vorschriften 
zur Gruppenbesteuerung voraus.

Das Ziel der Wahrung steuerlicher Belastungsgleichheit zwischen zwei Handlungsalternativen besitzt traditionell einen hohen Stellenwert im Bereich der Besteuerung von Anlagen in Publikumsinvestmentfonds. Investiert ein Anleger in Investmentanteile, soll ihm keine andere Steuerbelastung erwachsen, als hätte er ohne Zwischenschaltung eines Fonds direkt in die Anlagegegenstände investiert. Aus diesem Grund wurden Publikumsinvestmentfonds bislang (eingeschränkt) transparent besteuert: Wenngleich sie Steuersubjekte darstellen, waren sie bisher von der Körperschaftsteuer befreit; zudem unterlagen die durch den Fonds erzielten Erträge nicht der Gewerbesteuer. Getrieben von europarechtlichen Bedenken gegenüber der bisherigen Rechtslage, beschloss der Deutsche Bundestag in seiner Sitzung am 9. Juni 2016 ein Gesetz zur Reform der Investmentbesteuerung, das einen strukturellen Systemwechsel in der Besteuerung von Publikumsinvestmentfonds vorsieht. Mit der Aufgabe des Transparenzprinzips und der Einführung des Trennungsprinzips wird künftig auf Fondsebene Körperschaftsteuer auf bestimmte inländische Einkünfte des Fonds fällig. Zum Ausgleich werden dem Fondsanleger in Abhängigkeit von der Zusammenstellung des Fondsportfolios spezielle Steuerfreistellungen gewährt. Im ersten Beitrag der Dissertation („Zur Diskussion der Besteuerung von Wertpapier-Publikumsfonds in Deutschland“) wird vor diesem Hintergrund untersucht, welche Auswirkungen diese Bemessungsgrundlageneffekte auf die effektive Steuerbelastung von Fondsinvestments und damit auf die relative steuerliche Vorteilhaftigkeit von Direkt- und Fondsanlage haben.

Die steuerliche Differenzierung zwischen verschiedenen durch Investmentfonds erzielten Einkunftsarten stellt eine beispielhafte Ausprägung von Steuerasymmetrien im Allgemeinen dar, die international weit verbreitet sind und verschiedene Komponenten der steuerlichen Bemessungsgrundlage betreffen. Besondere Prominenz in der Literatur genießt die asymmetrische Besteuerung von Gewinnen und Verlusten. Für die Besteuerung des Einkommens natürlicher wie juristischer Personen besitzt das Nettoprinzip als grundlegendes Prinzip übergeordnete Bedeutung. Hiernach ergeben sich die steuerpflichtigen Einkünfte eines Unternehmens als Unterschiedsbetrag zwischen dessen steuerpflichtigen Einnahmen und steuerlich abzugsfähigen Ausgaben. Übersteigen die Einnahmen die Ausgaben, unterliegt der Gewinn in der Periode seines Entstehens der Besteuerung. Ergibt sich dagegen ein Nettoverlust, erfolgt regelmäßig keine spiegelbildliche periodengleiche Steuererstattung. Anstelle eines sofortigen und umfassenden Verlustausgleichs wird dem Steuerpflichtigen im Wege des intertemporalen Verlustausgleichs (sog. Verlustabzug) gestattet, den steuerlichen Verlust des laufenden Jahres mit steuerlichen 
Gewinnen zukünftiger Jahre (Verlustvortrag) oder vergangener Jahre (Verlustrücktrag) zu verrechnen. Die Vorschriften zum Verlustabzug unterscheiden sich im Ländervergleich teils deutlich. Abgesehen davon, dass ein Verlustrücktrag ohnehin nur in wenigen Ländern zulässig ist, wird er üblicherweise nur in zeitlich und betragsmäßig eingeschränktem Umfang gewährt. In Bezug auf den Verlustvortrag ist zwar festzustellen, dass zahlreiche Länder auf zeitliche Beschränkungen verzichten. Wo Verlustvorträge allerdings einer zeitlich begrenzten Nutzbarkeit unterworfen sind, hat dies zur Folge, dass ein aus früheren Jahren vorgetragener Verlust nach Ablauf der Vortragsdauer verfällt, insoweit er nicht gegen Gewinne verrechnet werden konnte. Einige Länder beschränken auch den Betrag, bis zu dem ein vorhandener Verlustvortrag mit laufenden Gewinnen verrechnet werden darf. Derartige Restriktionen werden als „Mindestbesteuerung“ bezeichnet, da sie bei betroffenen Unternehmen einen Mindestanteil des Gewinns der Besteuerung zuführen, und zwar auch dann, wenn grundsätzlich in ausreichendem Umfang Ausgleichspotential zur Kompensation verfügbar wäre.

Während sich die nachteiligen Wirkungen des Aufschubs der Verlustverrechnung in Ländern mit zeitlich unbeschränkter Verlustvortragsdauer auf negative Zinseffekte beschränken, besteht in Ländern mit zeitlicher Beschränkung des Verlustvortrags die Gefahr, dass Unternehmen zusätzlich negative Bemessungsgrundlageneffekte erleiden, wenn Verluste anteilig ungenutzt untergehen. Der mögliche rentabilitätsmindernde Einfluss restriktiver Vorschriften zur intertemporalen Verlustnutzung sollte insbesondere in solchen Fällen Eingang in das Entscheidungskalkül finden, in denen die Wahrscheinlichkeit des Eintritts steuerlicher Verluste hoch ist. Das unternehmerische Entscheidungsproblem der Standortwahl weist dieses Merkmal auf-hohe Kosten im Zusammenhang mit der Neugründung eines Unternehmens lassen, möglicherweise zusätzlich in Verbindung mit schlechten Ertragsaussichten in der Anlaufphase, auf eine erhöhte Wahrscheinlichkeit des Eintritts von Verlusten in den ersten Jahren der Geschäftstätigkeit schließen. Bisherige Studien zur unternehmerischen Standortwahl haben diesen Aspekt nicht beleuchtet. Der Beitrag des zweiten Papiers der vorliegenden Dissertation („Location of intra-EU greenfield FDI: Do tax loss offset restrictions matter?") besteht mithin in der Untersuchung der Frage, ob und, wenn ja, in welchem Ausmaß europäische multinationale Unternehmen den zu erwartenden negativen Rentabilitätswirkungen einer steuerlich nachteiligen Verlustbehandlung bei der Entscheidung über die internationale Standortwahl von Tochterkapitalgesellschaften Relevanz beimessen.

Neben den direkten Anreizwirkungen einer steuerlichen Benachteiligung von Verlusten, fin- 
den in der Literatur die aus der Abschirmwirkung steuerlicher Verlustvorträge resultierenden Entscheidungswirkungen Beachtung. Unternehmen mit steuerlichen Verlustvorträgen befinden sich in einem quasi-steuerfreien Zustand, solange in Grenzbetrachtung eine zusätzliche Einheit Gewinn durch den marginalen Abbau eines verfügbaren Verlustvortrags kompensiert wird. Der unternehmensindividuelle Steuerstatus hängt somit im Einzelfall davon ab, ob das Unternehmen über einen Verlustvortrag verfügt, wie groß dieser Verlustvortrag ist und wann der Verlustvortrag aufgebraucht ist, mit der Folge, dass das Unternehmen wieder in einen faktisch steuerpflichtigen Zustand versetzt wird. Einschlägige ökonometrische Studien zum Einfluss der Besteuerung auf Investitions-, Finanzierungs- und Gewinnverlagerungsentscheidungen weisen auf teilweise widersprüchliche und in Bezug auf die identifizierten Effektstärken nur mäßig bedeutsame Entscheidungswirkungen der Besteuerung hin. Ursächlich dafür sind Ungenauigkeiten bei der Messung der unternehmensspezifischen Steuerbelastung. Die Verwendung tariflicher Steuersätze birgt die größte Messungenauigkeit, da Vorschriften zur Ermittlung der Bemessungsgrundlage vollständig ausgeblendet werden. Grundsätzlich vollständig reflektiert sind diese Vorschriften in unternehmensspezifischen jahresabschlussbezogenen Steuerquoten, die beispielsweise den Steueraufwand ins Verhältnis zu einer Ergebnisgröße setzen. Problematisch an diesem Vorgehen ist die Vergangenheitsbezogenheit, die einer Erfassung der Wirkungen künftiger Steuerreformen entgegensteht und die mangelnde Eignung dieser Variablen zur Erklärung zukunftsorientierter Unternehmensentscheidungen erklärt. In der Verwendung investitionstheoretischer Effektivsteuersätze nach King \& Fullerton (1984) und Devereux \& Griffith (1999) ist ebenfalls keine Ideallösung zu sehen, da sie regelmäßig für ein deterministisch vorgegebenes hypothetisches Investitionsprojekt ermittelt werden und keine Berücksichtigung von Verlusten zulassen.

Das auf den Arbeiten von Shevlin (1987), Shevlin (1990) und Graham (1996a) basierende Konzept simulierter Grenzsteuersätze erlaubt hingegen eine vollständige Modellierung steuerlicher Parameter und deren Anwendung auf einen unternehmensindividuell und unter Unsicherheit simulierten Ergebnisstrom. Die Grenzsteuerbelastung entspricht in diesem Konzept dem Barwert der laufenden und zukünftigen Steuerzahlungen, die aus einer marginalen Erhöhung des steuerpflichtigen Einkommens um eine Einheit in der laufenden Periode resultieren. Hinsichtlich der grundsätzlichen Definition der Grenzsteuerbelastung besteht zwar weitgehend Klarheit, und obwohl die methodische Überlegenheit dieses Konzepts zur Ermittlung unternehmensspezifischer Steuerbelastungen anerkannt ist, indizieren die Ergebnisse empirischer Studien, dass die detailliertere Modellierung des Steuerstatus von Unternehmen durch Verwendung simulier- 
ter Grenzsteuersätze den Erklärungsgehalt ökonometrischer Modelle allenfalls geringfügig zu steigern vermag. Koch (2014a) identifiziert diesbezüglich zwei mögliche Quellen von Messungenauigkeiten. Die Qualität der den tatsächlichen Steuerstatus reflektierenden Variable hängt demnach zum einen vom angewendeten Simulationsalgorithmus ab. Zum anderen weist er nach, dass die Verwendung konsolidierter Jahresabschlüsse, wie in der US-amerikanischen Literatur üblich, zu einer weniger präzisen Messung des Steuerstatus im Zusammenhang mit Finanzierungsentscheidungen führt als die Simulation auf Grundlage unkonsolidierter Jahresabschlüsse. In der US-amerikanischen Literatur werden die im konsolidierten Abschluss ausgewiesenen Informationen zu latenten Steuern genutzt, um das fortzuschreibende, aber in der Realität nicht beobachtbare, steuerpflichtige Einkommen zu approximieren. Ein alternativer Ansatz sieht die Trennung der Prognose der unternehmensspezifischen Ergebnisentwicklung von der Modellering der steuerlichen Konsequenzen vor, indem zunächst eine Simulation des handelsrechtlichen Ergebnisses unter Unsicherheit erfolgt und die projizierten Ergebnisse sodann zu steuerpflichtigen Einkommen übergeleitet werden. Der dritte Beitrag der Dissertation („The sensitivity of simulated marginal tax rates to specific tax rules") diskutiert und analysiert die Eignung dieses Ansatzes im europäischen Kontext, wobei im Zentrum der Untersuchung die Frage steht, welche steuerrechtlichen Vorschriften bei der Ermittlung der Steuerbelastungen berücksichtigt werden sollten. Für ein Panel europäischer Unternehmen werden simulierte Grenzsteuersätze ermittelt, die auf ihre Sensitivität gegenüber unterschiedlichen steuerlichen Bemessungsgrundlagenvorschriften hin untersucht und bezüglich ihrer Eignung zur Messung des tatsächlichen unternehmerischen Steuerstatus evaluiert werden.

Zusammenfassend hat die vorliegende Dissertation das übergeordnete Ziel, das Verständnis der Bedeutung von Bemessungsgrundlageneffekten für das Entscheidungsverhalten von Wirtschaftsakteuren zu vertiefen. Angesichts des länderübergreifenden Trends zu sogenannten Taxcut-cum-base-broadening-Reformen, bei denen eine Senkung des tariflichen Steuersatzes mit einer Verbreiterung der Bemessungsgrundlage einhergeht, sind Erkenntnisgewinne hinsichtlich der Entscheidungserheblichkeit von Bemessungsgrundlagenkomponenten insbesondere für politische Entscheidungsträger relevant. Die wissenschaftliche Relevanz ergibt sich nicht allein aus der Untersuchung bislang nicht untersuchter Zusammenhänge; vielmehr setzt sich die Dissertation mit alternativen Möglichkeiten der Messbarmachung des das Entscheidungsverhalten beeinflussenden Steuerstatus von Entscheidern auseinander, diskutiert Stärken und Schwächen der verschiedenen Ansätze und zeigt Erweiterungsmöglichkeiten auf. 


\section{Kapitel B}

Zur Diskussion der Besteuerung von

Wertpapier-Publikumsfonds in Deutschland

\section{Zusammen mit Andreas Oestreicher}

Erschienen in: Steuer und Wirtschaft $91(2)$, 2014, S. 159-174

ISSN: 0341-2954 


\section{Motivation und Zielsetzung der Untersuchung}

Investitionen in Wertpapier-Publikumsfonds stellen eine spezielle und zunehmend stärker nachgefragte Form der Kapitalanlage in Wertpapiere dar. ${ }^{1}$ Während der Direktanleger unmittelbar in Aktien oder Anleihen eines Unternehmens investiert und ihm die hieraus entstehenden Erträge direkt zufließen, ${ }^{2}$ legt der Fondsanleger seine Geldmittel zunächst in einen von einer Kapitalverwaltungsgesellschaft verwalteten Fonds ein, aus dem heraus sodann die Anlage erfolgt. Der wesentliche Unterschied zur Direktanlage besteht folglich in der Zwischenschaltung einer Vermögensmasse, die - je nach zivilrechtlicher Ausgestaltung des Fonds als Investmentaktiengesellschaft oder Sondervermögen - eine eigenständige Rechtsfähigkeit aufweisen kann oder nicht. Folge dieser Zwischenschaltung ist auch, dass die Rechte des Anlegers nicht (direkt) in Aktien oder Anleihen des Unternehmens, in das investiert wird, sondern vielmehr in Anteilen am investierenden Fonds verbrieft sind. ${ }^{3}$

Die tradierte und bislang vom deutschen Gesetzgeber verfolgte Leitidee einer materiell steuerlichen Gleichstellung von Direkt- und Fondsanlage findet ihren Niederschlag in der eingeschränkten steuerlichen Transparenz von Investmentfonds. ${ }^{4}$ Vergleichbare Ausgestaltungen des Investmentsteuerrechts finden sich, von Ausnahmen im Einzelfall abgesehen, auch in Dänemark, Luxemburg, den Niederlanden, der Schweiz und dem Vereinigten Königreich. ${ }^{5}$ Spätestens seit dem 3.3. 2011 jedoch steht das geltende Regelwerk zur Besteuerung von Erträgen aus Investmentfonds ernsthaft in der politischen Diskussion. Die Finanzministerkonferenz von diesem Tag stellte nicht nur eine außerordentliche Komplexität der Investmentbesteuerung de lege lata fest; mit der Einrichtung einer der Federführung des Bundes sowie der Länder Hessen und NordrheinWestfalen unterstehenden länderoffenen Arbeitsgruppe wurde vielmehr auch die Erarbeitung eines konkreten Reformvorschlags initiiert, der die im geltenden Investmentsteuerrecht ausgemachten Probleme ${ }^{6}$ beheben und dabei gleichzeitig das inländische Steuersubstrat schonen soll. ${ }^{7}$

1 In den Jahren 2000 bis 2012 stieg die Anzahl der in Deutschland vertriebenen Publikums-Rentenfonds um 304 Prozent, die Anzahl der Publikums-Aktienfonds wuchs im gleichen Zeitraum um 336 Prozent. Die mit Abstand größte Zuwachsrate verzeichnen mit 755 Prozent die Mischfonds; vgl. BVI, 2013.

2 Im Rahmen dieses Beitrags wird die - in der Realität regelmäßig bestehende - Einbindung einer Depotbank ausgeklammert. Diese Maßnahme dient der Reduktion der Darstellung auf das für die Analyse der steuerlichen Folgen Wesentliche und hat auf das Ergebnis keine Auswirkungen.

3 Direkt- und Fondsanlage weisen darüber hinaus noch zahlreiche weitere Unterschiede auf, deren Berücksichtigung für die Untersuchung der relativen steuerlichen Vorteilhaftigkeit untereinander allerdings keine Notwendigkeit darstellt.

4 Vgl. Deutscher Bundestag, 2003, S. 120.

5 Vgl. Oestreicher \& Hammer, 2014, S. 52-56.

6 Für einen Überblick der als problematisch angesehenen Regelungen des aktuellen Investmentsteuerrechts vgl. o. V., 2012, S. 6-17.

7 Vgl. Steinmüller, 2012, S. 808 f. 
Motiviert durch die seitens der Wirtschaftsverbände vorgebrachte Ablehnung gegenüber dem am 24. 2. 2012 veröffentlichten zweiten Entwurf einer Neukonzeption der Investmentbesteuerung ${ }^{8}$ sollen im vorliegenden Beitrag die aus einer Umsetzung des Reformvorschlags in geltendes Recht resultierenden Effekte auf die effektive Steuerbelastung von Fondsinvestments und damit auf die relative steuerliche Vorteilhaftigkeit von Direkt- und Fondsanlage aufgezeigt werden. Hierzu beschränkt sich die Untersuchung auf ausschließlich in Aktien und Anleihen von Kapitalgesellschaften investierende Publikumsfonds mit unbeschränkt steuerpflichtigen, natürlichen Personen als Anleger. Ferner wird ein reiner Inlandsbezug zugrundegelegt, das heißt sowohl der Anleger als auch der Fonds und die Anlageobjekte werden als in Deutschland ansässig oder belegen angenommen.

Die Untersuchung ist wie folgt aufgebaut. In Abschnitt 2 wird zunächst auf die steuerliche Behandlung der Direktanlage in Aktien und Anleihen eingegangen. In Abschnitt 3 wird die Besteuerung der Investition in Wertpapier-Publikumsfonds dargestellt. Hierbei wird, soweit erforderlich, analog zu Abschnitt 2 danach unterschieden, ob der Fonds in Aktien oder Anleihen investiert ist. Wo im Einzelfall von Bedeutung, werden der geltenden Rechtslage ferner die geplanten Änderungen gegenübergestellt. Abschnitt 4 umfasst den quantitativen Teil, in dem die Anlagealternativen unter dem Gesichtspunkt der effektiven Steuerbelastung miteinander verglichen werden. Hierbei stehen zwei Fragen im Mittelpunkt: Erstens soll analysiert werden, welche Belastungswirkungen vom Reformvorschlag in Bezug auf die relative Vorteilhaftigkeit der Fondsanlage gegenüber der Direktanlage ausgehen. Zweitens ist bei isolierter Betrachtung der Fondsanlage von Interesse, ob, und wenn ja, für welche Szenarien, aus dem Reformvorschlag steuerliche Vor- oder Nachteile zu erwarten sind und welche Steueraufkommenseffekte mit einer Umsetzung der Reform potentiell verbunden wären. Die wesentlichen Untersuchungsergebnisse werden in Abschnitt 5 zusammengefasst.

\section{Besteuerung der Direktanlage}

\subsection{Abgrenzung des Untersuchungsgegenstands}

Bei der Direktanlage in ein Unternehmen lässt sich in Bezug auf den Kapitalgeber danach differenzieren, ob er als Eigenkapitalgeber auftritt und Aktien an dem Unternehmen erwirbt oder als Fremdkapitalgeber Anleihen von dem Unternehmen zeichnet. Die steuerliche Behandlung

8 Vgl. Wirtschaftsverbände, 2012. 
von Eigen- und Fremdkapital ist nach geltendem Recht sowohl auf Unternehmens- als auch auf Anlegerebene diametral verschieden. Ziel des vorliegenden Beitrags ist es, die steuerlichen Belastungsfolgen unterschiedlicher Anlagealternativen aus Sicht des Anlegers aufzuzeigen und zu analysieren; daher wird nachfolgend auf die Darstellung der Besteuerung auf Unternehmensebene verzichtet.

Die auf der Anlegerebene einsetzende steuerliche Behandlung der Erträge ist abhängig von der Zuordnung der Wertpapiere zum Privatvermögen oder Betriebsvermögen des Anlegers.

\subsection{Wertpapiere im Privatvermögen}

Die dem Anleger bei einer Investition in Aktien zufließenden Dividenden unterliegen im Ausschüttungszeitpunkt gemäß $\S 20$ Abs. 5 EStG als Kapitalerträge im Sinne des $\S 20$ Abs. 1 Nr. 1 EStG dem Kapitalertragsteuerabzug nach $\S 43$ Abs. 1 Satz 1 Nr. 1 EStG. Die ausschüttende Kapitalgesellschaft ist verpflichtet, für Rechnung des Anlegers Kapitalertragsteuer zuzüglich Solidaritätszuschlag in Höhe von insgesamt 26,375 Prozent einzubehalten und an das Finanzamt abzuführen, § 44 Abs. 1 EStG. Insoweit die Kapitalgesellschaft Gewinne nicht an den Anleger ausschüttet, wird auf dessen Ebene keine Einkommensteuerpflicht begründet.

Erzielt der Anleger aus der Veräußerung der Aktien einen Gewinn und betrug die Beteiligungsquote am Kapital der Gesellschaft innerhalb der letzten fünf Jahre nicht unmittelbar oder mittelbar mindestens 1 Prozent, fällt der Veräußerungsgewinn unter $\S 20$ Abs. 2 Satz 1 Nr. 1 EStG mit der Folge eines Abzugs von Kapitalertragsteuer inklusive Solidaritätszuschlag in Höhe von 26,375 Prozent. Wurde die 1-Prozent-Grenze hingegen im maßgeblichen Zeitraum überschritten, ist $\S 17$ EStG einschlägig. Die Erträge aus der Veräußerung der Aktien sind in diesem Fall als Einkünfte aus Gewerbebetrieb zu versteuern, wobei anstelle einer Abgeltungsbesteuerung die Veranlagung der Einkünfte und deren Besteuerung nach Maßgabe des Einkommensteuertarifs nach $\S 32 \mathrm{a}$ EStG erfolgt. Eine Gewerbesteuerpflicht wird durch unter $\S 17$ EStG fallende Veräußerungsgewinne derweil nicht begründet, R 7.1 Abs. 3 GewStR 2009.

Zeichnet der Anleger Anleihen an einer Kapitalgesellschaft, fließen ihm während der Laufzeit der Anleihe Zinsen zu, wiederum gemindert um die fälligen und seitens der auszahlenden Gesellschaft abzuführenden Abzugsteuern, § 43 Abs. 1 Satz 1 Nr. 7 i.V.m. § 44 Abs. 1 Satz 4 Nr. 1 lit. b EStG. Ist der Anleihezeichner gleichzeitig Anteilseigner der Kapitalgesellschaft, liegt eine Gesellschafterfremdfinanzierung vor. In diesem Fall greift die Abgeltungsteuer nur, wenn die 
Beteiligungsquote des Anlegers unter zehn Prozent liegt. Ab einer Beteiligung von zehn Prozent werden die Zinserträge dem progressiven Einkommensteuertarif des $\S 32 \mathrm{a}$ EStG unterworfen, $\S 32$ d Abs. 2 Nr. 1 lit. b EStG.

Gewinne aus der Veräußerung von Anleihen stellen grundsätzlich Einkünfte aus Kapitalvermögen dar, § 20 Abs. 2 Satz 1 Nr. 7 EStG, die damit in Bezug auf den Einbehalt von Kapitalertragsteuer wie Gewinne aus der Veräußerung von Aktien zu behandeln sind. Folglich sind 26,375 Prozent Steuern einzubehalten und für Rechnung des Anlegers abzuführen. Auch in Bezug auf die Veräußerung von Rentenpapieren steht die Anwendbarkeit der Abgeltungsteuer unter dem Vorbehalt, dass der Anleger entweder nicht gleichzeitig Anteilseigner der Gesellschaft ist oder, falls doch, die Beteiligungsquote nicht mindestens zehn Prozent beträgt. Andernfalls unterliegt der Veräußerungsgewinn entsprechend der steuerlichen Behandlung ordentlicher Zinserträge dem Einkommensteuertarif nach $\S 32 \mathrm{a}$ EStG, $\S 32$ d Abs. 2 Nr. 1 lit. b EStG.

Der Steuerabzug entfaltet in jedem der vier aufgezeigten Fälle grundsätzlich Abgeltungswirkung, das heißt, die Steuerschuld des Anlegers ist mit dem Einbehalt der fälligen Steuern an der Quelle der Erträge und deren Abführung an das Finanzamt beglichen und es kommt zu keinen weiteren Steuerfolgen auf Anlegerebene, $§ 43$ Abs. 5 Satz 1 EStG. Wenngleich die Kapitalertragsteuer in ihrer funktionalen Ausgestaltung als Abgeltungsteuer den Regelfall der Besteuerung von Anlegern mit Wertpapierbesitz im Privatvermögen darstellt, steht sie unter dem Vorbehalt der Günstigerprüfung nach $\S 32$ d Abs. 6 EStG. Danach werden die Kapitaleinkünfte auf Antrag des Anlegers dem Einkommensteuertarif gemäß § 32a EStG unterworfen, sofern sich hieraus eine geringere Belastung aus Einkommensteuer einschließlich Solidaritätszuschlag ergibt als unter dem Regime der Abgeltungsteuer.

\subsection{Wertpapiere im Betriebsvermögen}

Bedingt durch die Subsidiaritätsklausel des $\S 20$ Abs. 8 EStG, sind die ordentlichen und außerordentlichen Erträge aus der Anlage in Aktien und Anleihen nicht unter $\S 20$ EStG zu fassen, wenn die Wertpapiere einem Betriebsvermögen des Steuerpflichtigen zuzuordnen sind. In diesem Fall stellen die Erträge gewerbliche Einkünfte im Sinne von § 15 EStG dar und werden nicht im Wege des Steuerabzugs erfasst; der Anleger ist stattdessen zur Einkommensteuer zu veranlagen und hat seine Erträge dem Normaltarif des § 32a EStG zu unterwerfen.

Erfolgt die Anlage in Aktien, findet das Teileinkünfteverfahren Anwendung. Hiernach sind 40 
Prozent sowohl der ordentlichen als auch der außerordentlichen Erträge aus der Aktienanlage steuerfrei, $\S 3$ Nr. 40 lit. a, d EStG. Auf Erträge aus der Investition in Anleihen findet das Teileinkünfteverfahren dagegen keine Anwendung.

Neben der Einkommensteuerpflicht folgt aus der Qualifikation der Kapitalerträge als Einkünfte aus Gewerbebetrieb auch eine Steuerpflicht im Rahmen der Gewerbesteuer, $§ 7$ Satz 1 GewStG. In Bezug auf die Aktienanlage ist zu berücksichtigen, dass die einkommensteuerliche Teilfreistellung der Dividenden für Zwecke der Gewerbesteuer nur unter der Voraussetzung gewährt wird, dass die Beteiligungsquote an der Kapitalgesellschaft mindestens 15 Prozent beträgt, $\S 8$ Nr. 5 GewStG. Bei geringeren Beteiligungsquoten unterliegen die Dividenden in voller Höhe der Gewerbesteuerpflicht. Für Gewinne aus der Veräußerung von Aktien sieht das Gewerbesteuergesetz derweil kein Mindestbeteiligungserfordernis vor, die 40-prozentige Freistellung bleibt mithin bestehen.

Über $\S 35$ EStG findet die Gewerbesteuerbelastung einkommensteuerlich Berücksichtigung. Der Anleger mit Fondsanteilsbesitz im Betriebsvermögen kann demnach in pauschalierter Form das bis zu 3,8fache des Gewerbesteuermessbetrags auf seine tarifliche Einkommensteuer anrechnen, wobei die Anrechnung auf die tatsächlich gezahlte Gewerbe- und Einkommensteuer begrenzt ist.

\section{Besteuerung der Fondsanlage nach geltendem Recht und dem Reformentwurf}

\subsection{Abgrenzung des Untersuchungsgegenstands}

Zentrales Charakteristikum von Investmentfonds ist die Gemeinschaftlichkeit der Kapitalanlage. Dies kommt auch in der aufsichtsrechtlichen Begriffsbestimmung zum Ausdruck, die ein Investmentvermögen als „Organismus für gemeinsame Anlagen, der von einer Anzahl von Anlegern Kapital einsammelt, um es gemäß einer festgelegten Anlagestrategie zum Nutzen dieser Anleger zu investieren (... ) “ definiert. ${ }^{9}$ Das deutsche Aufsichtsrecht setzt in Bezug auf die Möglichkeiten zur rechtlichen Auskleidung öffentlich vertriebener Investmentfonds Schranken, sie dürfen nur als Sondervermögen (Publikums-Investmentfonds des Vertragstyps) oder als Investmentaktiengesellschaften mit veränderlichem Kapital (Publikums-Investmentfonds des Gesellschaftstyps) aufgelegt werden, $\S 91$ Abs. 1 KAGB.

$9 \quad \S 1$ KAGB. Zur weiteren Abgrenzung wird ferner konkretisiert, dass operativ tätige Unternehmen außerhalb des Finanzsektors nicht als Investmentfonds qualifizieren, vgl. ebenda. 
Bei Investmentfonds des Vertragstyps umfasst das Sondervermögen die Menge der seitens der Anleger eingelegten Geldmittel sowie die damit angeschafften Anlageobjekte. Das Sondervermögen selbst ist nicht rechtsfähig. ${ }^{10}$ Es ist eine Kapitalverwaltungsgesellschaft einzusetzen, die als Verwalterin des Sondervermögens tätig wird und unter Wahrung vorher festgelegter Anlagebedingungen die im Sondervermögen gebundenen finanziellen Mittel risikostreuend zum Nutzen der Anleger in Wertpapiere investiert, $\S \S 17,26$ KAGB. Die zum Sondervermögen gehörenden Vermögensgegenstände können in Abhängigkeit von den Anlagebedingungen der Kapitalverwaltungsgesellschaft entweder in deren Eigentum oder im Miteigentum der Anleger stehen, § 92 Abs. 1 Satz 1 KAGB. In beiden Fällen ist die Kapitalverwaltungsgesellschaft diesbezüglich Treunehmerin. ${ }^{11}$ Das Sondervermögen ist getrennt vom eigenen Vermögen der Kapitalverwaltungsgesellschaft zu halten, § 92 Abs. 1 Satz 2 KAGB. Die Verbriefung der Anteile der Anleger am Sondervermögen erfolgt in Form von Anteilscheinen, § 95 KAGB.

In der Variante des Gesellschaftstyps ist der Investmentfonds rechtlich als Investmentaktiengesellschaft ${ }^{12}$ konzipiert. Während die Verwaltung von als Sondervermögen ausgestalteten Fonds stets durch eine (externe) Kapitalverwaltungsgesellschaft erfolgen muss, ist bei Fonds des Gesellschaftstyps neben einer solchen Fremd- auch eine Selbstverwaltung des Fondsvermögens möglich, $\S 17$ Abs. 2 Nr. 2 KAGB. Erfolgt eine Fremdverwaltung, gilt auch hier das Gebot der Trennung zwischen dem Vermögen des Fonds (der Investmentaktiengesellschaft) und dem Vermögen der Kapitalverwaltungsgesellschaft. Keine Vermögenstrennung erfolgt hingegen auf der Fondsebene selbst. Das originäre, für Zwecke der Kapitalanlage durch die Anleger in die Investmentaktiengesellschaft eingelegte Kollektivvermögen und das restliche Vermögen der Investmentaktiengesellschaft bilden gemeinsam das (eine) Vermögen der Investmentaktiengesellschaft, ${ }^{13}$ an dem sich die Anleger als Anlageaktionäre beteiligen. Verbrieft werden die Ansprüche der Anleger in Anlageaktien ohne Stimmrecht, die diesbezüglich als Äquivalente zu den Anteilscheinen bei als Sondervermögen aufgelegten Fonds anzusehen sind. ${ }^{14}$

\footnotetext{
10 Vgl. Schmitz, 2010b, Rn. 10.

11 Vgl. Schmitz, 2010a, Rn. 5.

12 Im Folgenden wird auf den Zusatz „mit veränderlichem Gesellschaftskapital“ verzichtet.

13 Vgl. Englisch, 2010, Rn. 6.

14 Vgl. Fischer \& Steck, 2010, Rn. 10; Patzner \& Döser, 2012, Rn. 1.
} 


\subsection{Besteuerung des Investmentfonds}

\subsubsection{Steuerrechtssubjektivität und eigenständige Steuerpflicht von Investmentfonds}

Das Vorhandensein der Ebene eines Investmentfonds als dritter Ebene neben denen der Anlageobjekte und des Anlegers eröffnet die Gelegenheit, auch dort Anknüpfungspunkte für die Besteuerung zu setzen. Voraussetzung dafür ist, dem Fonds eine eigenständige steuerliche Leistungsfähigkeit zuzuschreiben und ihn als Steuersubjekt zu qualifizieren. Orientiert man sich für Zwecke der Zuschreibung einer eigenständigen Steuersubjektivität ausschließlich an der originären zivilrechtlichen Wertung, kann die außersteuerlich bestehende Rechtsfähigkeit von Investmentaktiengesellschaften für deren steuerliche Behandlung übernommen werden, während es im Fall zivilrechtlich nicht rechtsfähiger Sondervermögen an einem Bezugspunkt fehlt. Die steuerliche Zurechnung der durch den Fonds erzielten Einkünfte betreffend, wären diese mangels tatsächlicher Möglichkeiten der Anleger zur Einflussnahme auf die Verwaltung des Fondsvermögens nicht den Anlegern, sondern der Kapitalverwaltungsgesellschaft zuzurechnen und von dieser zu versteuern. ${ }^{15} \mathrm{Um}$ zu vermeiden, dass die Umsetzung der intendierten steuerlichen Gleichstellung von Fonds- und Direktanlage an verfahrenstechnischen Hindernissen scheitert, wird die Steuerrechtssubjektivität von als Sondervermögen aufgelegten Fonds fingiert, § 11 Abs. 1 Satz 1 InvStG. Im Ergebnis wird für die Besteuerung mithin nicht zwischen Fonds mit unterschiedlicher zivilrechtlicher Ausgestaltung differenziert.

Wenngleich Fonds deshalb dem Grunde nach Steuersubjekteigenschaft besitzen, werden sie nach geltendem Recht von der Körperschaftsteuer und der Gewerbesteuer befreit, § 11 Abs. 1 Satz 2, 3 InvStG. Die sachliche Ertragsteuerbefreiung ist notwendig, um Fondserträge in Übereinstimmung mit Erträgen aus der Direktanlage ertragsteuerlich nur einmal zu belasten. ${ }^{16}$ Überdies ist zur Vermeidung einer definitiven Kapitalertragsteuerbelastung auf der FondsEingangsseite die Abstandnahme vom Steuerabzug vorgesehen. Ersatzweise wird dem Fonds einbehaltene Kapitalertragsteuer erstattet, $\S 11$ Abs. 2 Satz 1 i.V.m. $\S 44 a$ Abs. 4 EStG. ${ }^{17}$

Der Entwurf zur Neukonzeption der Investmentbesteuerung sieht im Gegensatz zum bisherigen Recht vor, die Ertragsteuerbefreiung von Fonds insoweit fallen zu lassen, als zukünftig die durch den Fonds erzielten inländischen (Brutto-)Dividenden auf dessen Ebene einer Besteuerung mit 15 Prozent Körperschaftsteuer unterliegen sollen. ${ }^{18}$ Mit der beschränkten Einführung

\footnotetext{
15 Vgl. Englisch, 2010, Rn. 16.

16 Vgl. Englisch, 2010, Rn. 20.

17 Vgl. Englisch, 2010, Rn. 33.

18 Vgl. o.V., 2012, S. 21. Unter Berücksichtigung des Solidaritätszuschlags beliefe sich die tarifliche Gesamtbe-
} 
einer sachlichen Steuerpflicht auf im Inland erzielte Dividenden sollte die deutsche Fondsbesteuerung vor aus dem Europarecht resultierenden Ansprüchen geschützt und das Haushaltsrisiko für die Bundesrepublik Deutschland, das mit einem Fortbestehen der im geltenden Recht verankerten Freistellung inländischer Investmentfonds verbunden wäre, vermieden werden. ${ }^{19}$ Ausländische Dividenden sowie Zinsen und Gewinne, die der Fonds aus der Veräußerung von in seinem Portfolio befindlichen Aktien und Anleihen erzielt, unterlägen nachwievor nicht der Körperschaftsteuerpflicht. Im Übrigen soll zudem an der umfassenden Befreiung des Fonds von einer Besteuerung mit Gewerbesteuer festgehalten werden. ${ }^{20}$

\subsubsection{Investmentsteuerliche Sondervorschriften zur Ertragsermittlung auf Fondsebene}

Investmentfonds kommen nach geltendem Recht zwar in den Genuss einer sachlichen Steuerbefreiung, dennoch sind sie aufgrund ihrer Steuerrechtssubjektivität zur selbständigen Ertragsermittlung verpflichtet. ${ }^{21}$ Anders als für Körperschaftsteuersubjekte normalerweise üblich, haben Investmentfonds ihren Gewinn nicht durch Betriebsvermögensvergleich nach $\S 4$ Abs. 1 EStG zu ermitteln, sondern hierzu eine modifizierte Einnahmen-Überschussrechnung anzustellen. Die zeitliche Erfassung der Erträge auf Fondsebene richtet sich grundsätzlich nach dem einkommensteuerlichen Zu- und Abflussprinzip, § 3 Abs. 1 InvStG. Es erfährt jedoch vereinzelt gezielte Durchbrechungen. Dividendeneinkünfte werden, ungeachtet ihres tatsächlichen Zuflusses, bei Dividendenabschlag steuerlich erfasst, $\S 3$ Abs. 2 Satz 1 Nr. 1 InvStG. Dem Fonds zuzurechnende Zinserträge sind vom Zuflusszeitpunkt unabhängig periodengerecht abzugrenzen, § 3 Abs. 2 Satz 1 Nr. 2 InvStG. ${ }^{22}$

Zu möglichen Änderungen in der Ertragsermittlung bei Publikums-Wertpapierfonds enthält der Arbeitsgruppenberichtsentwurf zur Neukonzeption der Investmentbesteuerung keine Ausfüh-

lastung auf 15,825 Prozent.

19 Bedeutung kommt in diesem Zusammenhang dem EuGH-Urteil vom 20.10.2011 in der Rechtssache C-284/09 zu. In seiner Entscheidung stellte der EuGH fest, dass die Bundesrepublik Deutschland insoweit gegen die Kapitalverkehrsfreiheit verstoßen hat, als sie Dividenden, die an eine Gesellschaft mit Sitz in einem anderen Mitgliedsstaat oder im Europäischen Wirtschaftsraum ausgeschüttet wurden, wirtschaftlich einer höheren Besteuerung unterwarf als Dividenden, die an eine Gesellschaft mit Sitz in der Bundesrepublik Deutschland ausgeschüttet wurden. Durch die Einführung einer allgemeinen Steuerpflicht für Streubesitzdividenden, wurde der Verstoß gegen die Kapitalverkehrsfreiheit inzwischen beseitigt. Vgl. Fraedrich, 2012, S. 565; Kammeter, 2012, S. 1972 f.; Steinmüller, 2012, S. 813.

20 Vgl. o. V., 2012, S. 21. Der Berichtsentwurf enthält keine Aussagen zu der Frage, ob in Analogie zu der Vorschrift des $\S 8 \mathrm{~b}$ Abs. 3, $5 \mathrm{KStG}$ auch bei Fonds eine pauschale Nichtabziehbarkeit von fünf Prozent der Dividenden und Veräußerungsgewinne gelten soll; hieraus gegebenenfalls resultierende steuerliche Konsequenzen sind von daher auch in den nachfolgenden Berechnungen nicht berücksichtigt.

${ }^{21}$ Vgl. Thiems, 2013, S. 74.

22 Vgl. Patzner \& Döser, 2012, Rn. 6. 
rungen.

\subsection{Besteuerung des Fondsanlegers}

\subsubsection{Steuerbarkeit und Zuordnung der Einkünfte aus Fondsanteilen}

Die für die Regelbesteuerung des Fondsanlegers maßgeblichen Vorschriften finden sich in $\S 2$ InvStG. ${ }^{23}$ Nur die dort aufgeführten Ertragskomponenten können infolge der Spezialgesetzlichkeit des InvStG auf Anlegerebene überhaupt steuerbar sein. ${ }^{24}$ Das geltende Investmentsteuerrecht nimmt weder auf die originäre Einkünftenatur noch auf die Ertragsverwendung des Fonds Rücksicht. ${ }^{25}$ „Ausgeschüttete Erträge“ des Fonds aus der Investition in Aktien und Anleihen unterliegen insgesamt als Einkünfte aus Kapitalvermögen im Sinne des $§ 20$ Abs. 1 Nr. 1 EStG der sachlichen Steuerpflicht - und zwar auch dann, wenn auf Ebene des Fonds zum Beispiel Immobilien verwaltet und entsprechende Erträge ausgekehrt werden. Das gilt nicht, sofern diese Erträge - aufgrund Fondsanteilsbesitzes in einem Betriebsvermögen - Betriebseinnahmen des Anlegers darstellen, $\S 2$ Abs. 1 Satz 1 InvStG. „Ausgeschüttete Erträge“ stellen dabei den auf Anlegerebene steuerbaren Anteil an der Ausschüttung dar, ${ }^{26}$ wobei „Ausschüttung“ den dem Anleger einschließlich einbehaltener Kapitalertragsteuer tatsächlich gezahlten oder gutgeschriebenen Betrag meint, $\S 1$ Abs. 3 Satz 1 InvStG. Die nicht ausgeschütteten, sondern zur Thesaurierung im Fonds verwendeten ordentlichen Erträge aus Aktien und Anleihen erfahren mit Ablauf des Geschäftsjahres, in dem die Erträge vereinnahmt worden sind, auf Anlegerebene über eine Zuflussfiktion als „ausschüttungsgleiche Erträge" ebenfalls die steuerliche Erfassung als Einkünfte aus Kapitalvermögen im Sinne des $\S 20$ Abs. 1 Nr. 1 EStG, es sei denn, sie sind als Betriebseinnahmen des Anlegers zu qualifizieren, § 2 Abs. 1 Satz 1 InvStG. Ausdrücklich nicht steuerbar, da definitorisch nicht unter die „ausschüttungsgleichen Erträge“ fallend, sind die nicht zur Ausschüttung verwendeten außerordentlichen Erträge des Fonds, $\S 1$ Abs. 3 Satz 3 Nr. 1 InvStG. Somit kommt eine Steuerpflicht des Anlegers in Bezug auf außerordentliche Erträge regelmäßig erst im Zeitpunkt ihrer Ausschüttung oder bei Veräußerung oder Rückgabe des Fondsanteils in Betracht.

\footnotetext{
${ }^{23}$ Die Strafbesteuerung bei fehlender Bekanntmachung der Besteuerungsgrundlagen nach $\S 6$ InvStG wird hier nicht betrachtet.

${ }^{24}$ Vgl. Lübbehüsen, 2010, Rn. 25; Berger, 2010, Rn. 257-259.

25 Während die in Deutschland gewinnverwendungsunabhängig erfolgende Erfassung der Erträge auf Anlegerebene im Ländervergleich einen Ausnahmefall darstellt, ist die Missachtung der originären Einkünftenatur international üblich; vgl. Oestreicher \& Hammer, 2014, S. 42, 46.

${ }^{26}$ Im Gesamtbetrag der Ausschüttung können auch nicht steuerbare Bestandteile enthalten sein; vgl. Berger, 2010, Rn. 272.
} 
Der Reformvorschlag zielt auf eine ausgeprägte konzeptionelle Neuausrichtung der Anlegerbesteuerung ab. Grundsätzlich soll dem Prinzip der Cashflow-Besteuerung folgend eine Besteuerung auf Anlegerebene erst in dem Zeitpunkt erfolgen, in dem es zum tatsächlichen Zufluss der Fondserträge beim Anleger kommt. Nach dieser Konzeption bleibt für die bisherige Unterscheidung zwischen ausgeschütteten und ausschüttungsgleichen Erträgen folgerichtig kein Raum mehr. Es ist zudem beabsichtigt, im Rahmen des $§ 20$ EStG einen neuen Tatbestand „Einkünfte aus Investmentvermögen " zu schaffen, statt, wie im geltenden Recht, alle Fondserträge unter $\S 20$ Abs. 1 Nr. 1 EStG und damit als dividendengleich zu subsumieren. ${ }^{27}$

\subsubsection{Fondsanteile im Privatvermögen}

Die dem Anleger steuerlich zuzurechnenden ausgeschütteten und ausschüttungsgleichen Erträge aus dem Investmentfonds unterliegen dem Steuerabzug vom Kapitalertrag zuzüglich Solidaritätszuschlag in Höhe von insgesamt 26,375 Prozent, $\S 7$ Abs. 1, 3, 4 InvStG. ${ }^{28}$ Die Einkommensteuerpflicht des Anlegers ist bei Fondsanteilsbesitz im Privatvermögen mit dem Steuerabzug grundsätzlich abgegolten, es sei denn, infolge der Günstigerprüfung gemäß § 32d Abs. 6 EStG ergibt sich bei Veranlagung des Anlegers zur Einkommensteuer eine geringere Steuerzahlung als bei Anwendung des gesonderten Steuersatzes.

Ein aus der Veräußerung oder Rückgabe des Fondsanteils erzielter Gewinn unterliegt als Kapitalertrag im Sinne von $\S 20$ Abs. 2 Satz 1 Nr. 1 EStG einem abgeltenden Kapitalertragsteuerabzug von 26,375 Prozent, wobei während der Haltedauer versteuerte ausschüttungsgleiche Erträge bei der Ermittlung des steuerpflichtigen Veräußerungsgewinns bemessungsgrundlagenmindernd zu berücksichtigen und hierauf aus dem Investmentfonds gezahlte Abzugsteuern hinzuzurechnen sind, $\S 8$ Abs. 5, 6 InvStG.

Während der Anleger auch unter dem Reformvorschlag mit den Ausschüttungen aus dem Fonds der Abgeltungsteuer unterliegen soll, ist grundsätzlich beabsichtigt, dass bei Thesaurierung auf den Steuerzugriff verzichtet wird. Diese Abstandnahme von der Besteuerung soll allerdings unter den Vorbehalt einer als angemessen angesehenen Ausschüttung gestellt werden. Bleiben die Ausschüttungen eines Jahres demnach hinter der Verzinsung des um zwanzig Prozent gekürzten ${ }^{29}$ Rücknahmepreises des Fondsanteils zu Jahresbeginn mit dem Basiszins im

\footnotetext{
27 Vgl. o. V., 2012, S. 22.

28 Vgl. Ramackers, 2010, Rn. 14-18. Eine detaillierte Aufstellung über die Entrichtungspflichtigen findet sich bei Hammer, 2013, Rn. $11 \mathrm{ff}$.

29 Der Ansatz von nur 80 Prozent des Rücknahmepreises soll pauschal den Anteil von Verwaltungskosten auf
} 
Sinne des $\S 203$ Abs. 2 BewG („risikolose Marktverzinsung“) zurück, obwohl der Fondsanteil im betreffenden Jahr eine Wertsteigerung verzeichnen konnte, soll auf Anlegerebene eine sogenannte „Vorabpauschale“ in Höhe dieser risikolosen Marktverzinsung als Mindestbemessungsgrundlage der Besteuerung unterliegen. Anlegern mit Fondsanteilsbesitz im Privatvermögen soll hierbei ein Freibetrag von 300 Euro gewährt werden. ${ }^{30}$ Etwaige tatsächliche Ausschüttungen sollen auf die anzusetzende Vorabpauschale, die überdies auf die tatsächliche Wertsteigerung des Fondsanteils im betrachteten Jahr begrenzt werden soll, angerechnet werden. Der Ansatz einer Vorabpauschale soll generell unterbleiben, wenn im betrachteten Jahr der Fondsanteil nicht im Wert gestiegen ist oder die Ausschüttungen die risikolose Marktverzinsung übersteigen. ${ }^{31}$

Veräußerungsgewinne des Anlegers sollen dem Entwurf zufolge entsprechend den ordentlichen Erträgen als „Einkünfte aus Investmentvermögen“ erfasst und - wie im geltenden Recht mit 26,375 Prozent Abgeltungsteuer inklusive Solidaritätszuschlag besteuert werden. Zur Vermeidung einer doppelten Besteuerung würden die während der Haltedauer angesetzten Vorabpauschalen wie nachträgliche Anschaffungskosten vom Veräußerungspreis abgezogen. Der Konzeptionsentwurf weist nicht darauf hin, dass - vergleichbar der geltenden Rechtslage - über die Laufzeit auf Vorabpauschalen entrichtete Steuern bei der Ermittlung des steuerpflichtigen Veräußerungsgewinns gewinnerhöhend anzusetzen sind, um dem Abzugsverbot für Personensteuern nach $\S 12$ Nr. 3 EStG Rechnung zu tragen. Vielmehr werden sie in dem im Bericht gegebenen Schema zur Ermittlung des Veräußerungsgewinns sogar außen vor gelassen. ${ }^{32}$ Für Zwecke des vorliegenden Beitrags wird diese Sichtweise daher als maßgeblich angenommen.

Stehen die vom Anleger zu versteuernden Erträge (während der Haltedauer vom Fonds gezahlte außerordentliche und ordentliche Erträge, Vorabpauschalen sowie Veräußerungs- oder Rückgabegewinne des Anlegers) im Zusammenhang mit der Beteiligung an einem zu mindestens 51 Prozent in Aktien investierten Fonds („Aktienfonds“), sollen diese in toto sowohl bei abgeltender Besteuerung als auch bei Veranlagung zur Einkommensteuer pauschal in den Genuss einer 20-prozentigen Freistellung kommen („Aktienteilfreistellung“), um der Vorbelastung der inländischen Dividendenerträge mit Körperschaftsteuer auf Fondsebene Rechnung zu tragen. ${ }^{33}$

Fondsebene abbilden, vgl. o. V., 2012, S. 23.

30 Vgl. Steinmüller, 2012, S. 814.

31 Vgl. o. V., 2012, S. 23 f.

32 Vgl. o. V., 2012, S. 25.

33 Vgl. o. V., 2012, S. 30 ff. 


\subsubsection{Fondsanteile im Betriebsvermögen}

Der Anwendungsbereich der Abgeltungsteuer erstreckt sich im geltenden Recht nur auf die Besteuerung von Anlegern mit im Privatvermögen gehaltenen Fondsanteilen. Bei Fondsanteilsbesitz im Betriebsvermögen stellen die ausgeschütteten und ausschüttungsgleichen Erträge sowie der Gewinn aus der Veräußerung oder Rückgabe des Fondsanteils hingegen Betriebseinnahmen dar, die der Besteuerung nach dem Normaltarif des $\S 32 \mathrm{a}$ EStG unterliegen. Soweit die dem Anleger zuzurechnenden Erträge aus der Investition des Fonds in Aktien stammen, kommt die 40-prozentige Freistellung im Rahmen des Teileinkünfteverfahrens zur Anwendung, $\S 3$ Nr. 40 EStG. ${ }^{34}$ Vorab auf Fondsausgangsseite für Rechnung des Anlegers einbehaltene Kapitalertragsteuer und Solidaritätszuschlag werden auf die tarifliche Steuerschuld des Anlegers angerechnet. Aufgrund der Gewerblichkeit der Einkünfte fällt auf Anlegerebene zusätzlich grundsätzlich Gewerbesteuer auf alle aus der Fondsanlage erzielten Erträge an. Die einkommensteuerlich gewährte 40-prozentige Freistellung gilt für Zwecke der Gewerbesteuer nur für Gewinne aus der Fondsanteilsveräußerung uneingeschränkt fort, während in Bezug auf die laufenden steuerpflichtigen Erträge aus dem Fonds nach $\S 8$ Nr. 5 GewStG eine Hinzurechnung vorzunehmen ist, sofern die Voraussetzungen des gewerbesteuerlichen Schachtelprivilegs nach $\S 9$ Nr. 2a, 7 GewStG seitens des Fondsanlegers nicht erfüllt werden. ${ }^{35}$

Die Arbeitsgruppe zur Neukonzeption der Investmentbesteuerung regt an, betrieblichen Anlegern zukünftig die Anwendung des Teileinkünfteverfahrens zu versagen. An der Befreiung von der Gewerbesteuer soll dagegen festgehalten werden. Im Übrigen wird vorgeschlagen, die Besteuerung des betrieblichen Anlegers weitgehend analog derjenigen des Privatanlegers vorzunehmen. ${ }^{36}$

\section{Auswirkungen einer Umsetzung des Reformvorschlags auf die effektive Steuerbelastung von natürlichen Personen}

\subsection{Berechnungsmethodik und Modellannahmen}

Zur Quantifizierung der auf der Direkt- oder Fondsanlage ruhenden Steuerbelastung wird auf das investitionstheoretische Maß der effektiven Steuerbelastung zurückgegriffen. Anders als die rechtliche Steuerbelastung, die das Verhältnis von Steuerzahlungen zu einer rechtlich definierten

\footnotetext{
34 Vgl. Wenzel, 2013, Rn. 17.

35 Die Nichterfüllung der Voraussetzungen des gewerbesteuerlichen Schachtelprivilegs dürfte der Regelfall sein; vgl. hierzu auch Patzner \& Kempf, 2012, Rn. 11-13.

36 Vgl. o. V., 2012, S. 28 f.
} 
Bemessungsgrundlage anzeigt, gibt die effektive Steuerbelastung die durch die Besteuerung verursachte Minderung der wirtschaftlichen Zielgröße eines Investors wieder. Beide Belastungsmaße unterscheiden sich in der Regel voneinander. Geht man davon aus, dass der rational handelnde Investor die Maximierung des finanzwirtschaftlichen Überschusses einer Investition und damit die Minimierung der Steuerzahlungen anstrebt, ist nicht in der rechtlichen, sondern vielmehr in der effektiven Steuerbelastung das relevante Entscheidungskriterium zu sehen. ${ }^{37}$ Da im vorliegenden Beitrag die Steuerwirkungen auf rentable Investitionsentscheidungen analysiert werden sollen, werden effektive Durchschnitts- statt Grenzsteuerbelastungen berechnet. Zu diesem Zweck werden für jede Fallkonstellation zunächst die dem Investor zufließenden Erträge einer Periode aus der Direkt- oder Fondsanlage vor und nach Steuern ermittelt, um hieraus die interne Verzinsung der sich über die Perioden ergebenden Zahlungsreihen zu berechnen. Die effektive Durchschnittssteuerbelastung errechnet sich dann als $s=\frac{r-r_{s}}{r}$, mit $r$ als internem Zinsfuß der Investition vor Steuern und $r_{s}$ als internem Zinsfuß der Investition nach Steuern. Die Ermittlung der Steuerzahlungen erfolgt über eine modellmäßige Nachbildung des Veranlagungsverfahrens der Finanzbehörden mittels einer kasuistischen Veranlagungssimulation ${ }^{38}$.

Betrachtet wird als Anleger eine in Deutschland unbeschränkt steuerpflichtige natürliche Person, die für die Dauer von fünf Jahren ein Kapital in Höhe von 1.000.000 Euro (Szenario 1: Vermögender Investor) oder 100.000 Euro (Szenario 2: Weniger vermögender Investor) alternativ direkt in Aktien oder Anleihen eines inländischen Unternehmens investiert oder sich zu diesem Zweck an einem inländischen Fonds beteiligt, der für Rechnung des Anlegers in die entsprechenden Aktien oder Anleihen investiert. Im Fall der Anlage über einen Fonds beläuft sich das Fondsvermögen annahmegemäß auf 200 Millionen Euro. Folglich hält der Anleger in den beiden Varianten einen 0,5-Prozent- oder 0,05-Prozent-Anteil am Investmentfonds. Es soll davon ausgegangen werden, dass diese Beteiligungsquoten auch für die gesellschaftsrechtliche Beziehung zwischen Zielunternehmen und Anleger im Fall der Direktanlage gelten. Damit werden die $\S \S 17$, 32d Abs. 2 Nr. 1 lit. b EStG nicht einschlägig und der Anwendungsbereich der Abgeltungsteuer bei Kapitalanlagen im Privatvermögen nicht verlassen. Unterschieden wird jeweils danach, ob die Wertpapiere (Aktien, Anleihen oder Fondsanteile) dem Privat- oder einem Betriebsvermögen des Anlegers zuzurechnen sind. Annahmegemäß verfolgt der Anleger entweder das Ziel, über die Investitionsdauer regelmäßige Zahlungen zu erhalten (im Folgenden als „Ausschüttungsfall“ be-

37 Vgl. Schreiber, 2012, S. 579-583. Für eine ausführliche Diskussion dieser Zusammenhänge siehe zudem Spengel \& Lammersen, 2001, S. 222-238.

38 Einen Überblick über die kasuistische Veranlagungssimulation einschließlich eines Anwendungsbeispiels gibt Jacobs, 1988, S. 331-413. 
Tabelle B.1: Untersuchte Fallkonstellationen

\begin{tabular}{|c|c|c|c|c|c|c|c|c|}
\hline \multirow{3}{*}{$\begin{array}{l}\begin{array}{l}\text { Anlage- } \\
\text { strategie }\end{array} \\
\text { Ertragsart } \\
\text { Anlagetyp }\end{array}$} & \multicolumn{4}{|c|}{$\begin{array}{l}\text { Zufluss regelmäßiger Zahlungen } \\
\text { (,Ausschüttungsfall“) }\end{array}$} & \multicolumn{4}{|c|}{$\begin{array}{l}\text { Langfristiger Wertzuwachs durch Verzicht auf regelmäßige Zahlungen } \\
\text { („Thesaurierungsfall“) }\end{array}$} \\
\hline & \multicolumn{2}{|l|}{ Dividenden } & \multicolumn{2}{|l|}{ Zinsen } & \multicolumn{2}{|l|}{ Dividenden } & \multicolumn{2}{|l|}{ Zinsen } \\
\hline & Direkt & Fonds & Direkt & Fonds & Direkt & Fonds & Direkt & Fonds \\
\hline Wertpapiere & $\begin{array}{l}\text { Aktien } \\
\text { (Zielunternehmen } \\
\text { schüttet aus) }\end{array}$ & $\begin{array}{l}\text { Anteilschein an } \\
\text { ausschüttendem } \\
\text { Aktienfonds }\end{array}$ & Anleihen & $\begin{array}{l}\text { Anteilschein an } \\
\text { ausschüttendem } \\
\text { Rentenfonds }\end{array}$ & $\begin{array}{l}\text { Aktien } \\
\text { (Zielunternehmen } \\
\text { thesauriert) }\end{array}$ & $\begin{array}{l}\text { Anteilschein an } \\
\text { thesaurierendem } \\
\text { Aktienfonds }\end{array}$ & $\begin{array}{l}\text { Null- } \\
\text { kupon- } \\
\text { anleihen }\end{array}$ & $\begin{array}{l}\text { Anteilschein an } \\
\text { thesaurierendem } \\
\text { Rentenfonds }\end{array}$ \\
\hline $\begin{array}{l}\text { Zahlungen } \\
\text { während der } \\
\text { Investitions- } \\
\text { dauer }\end{array}$ & $\begin{array}{l}\text { - Dividenden } \\
\text { - Kursgewinne } \\
\text { (realisiert durch } \\
\text { teilweise } \\
\text { Aktien- } \\
\text { veräußerung } \\
\text { durch den } \\
\text { Anleger) }\end{array}$ & $\begin{array}{l}\text { Fonds- } \\
\text { ausschüttung: } \\
\text { - Dividenden } \\
\text { - Kursgewinne } \\
\text { (realisiert } \\
\text { durch teilweise } \\
\text { Aktien- } \\
\text { veräußerung } \\
\text { durch den } \\
\text { Fonds) }\end{array}$ & $\begin{array}{l}\text { - Zinsen } \\
\text { - Kursgewinne } \\
\text { (realisiert } \\
\text { durch teil- } \\
\text { weise } \\
\text { Anleihe- } \\
\text { veräußerung } \\
\text { durch den } \\
\text { Anleger) }\end{array}$ & $\begin{array}{l}\text { Fonds- } \\
\text { ausschüttung: } \\
\text { - Zinsen } \\
\text { - Kursgewinne } \\
\text { (realisiert } \\
\text { durch teilweise } \\
\text { Anleihe- } \\
\text { veräußerung } \\
\text { durch den } \\
\text { Fonds) }\end{array}$ & Keine & & & \\
\hline $\begin{array}{l}\text { Zahlungen } \\
\text { am Ende der } \\
\text { Investitions- } \\
\text { dauer }\end{array}$ & \multicolumn{4}{|c|}{$\begin{array}{l}\text { - Durch Wertpapierveräußerung/-rückgabe realisierte Wertsteigerung des } \\
\text { Wertpapiers (resultierend aus bisher unrealisierten Kursgewinnen) } \\
\text { - Rückzahlung des Anlagebetrags }\end{array}$} & \multicolumn{4}{|c|}{$\begin{array}{l}\text { - Durch Wertpapierveräußerung/-rückgabe realisierte Wertsteigerung } \\
\text { des Wertpapiers } \\
\text { - Rückzahlung des Anlagebetrags }\end{array}$} \\
\hline
\end{tabular}

zeichnet) oder aber zugunsten eines langfristigen Wertzuwachses im gehaltenen Wertpapier auf regelmäßige Zuflüsse zu verzichten und stattdessen am Ende des Investitionszeitraums einen (entsprechend hohen) Einmalbetrag zu vereinnahmen (nachfolgend „Thesaurierungsfall“ genannt). Die untersuchten Fallkonstellationen werden in Tabelle B.1 zusammenfassend dargestellt.

Unrealisierte Kursgewinne folgen aus Kurssteigerungen der im Portfolio des Fonds oder Direktanlegers gehaltenen Wertpapiere, die nicht (durch teilweise Veräußerung) in Zahlungen überführt werden. Veräußerungsgewinne durch Umschichtungen im Fondsportfolio führen zu realisierten Kursgewinnen auf Ebene des Fonds, die im Fall eines ausschüttenden Fonds auch an den Fondsanleger ausgeschüttet werden. Zur Wahrung der Vergleichbarkeit zwischen den Anlagealternativen muss unterstellt werden, dass auch der betrachtete Direktanleger Teile seiner Aktien oder Anleihen veräußert, um Kurssteigerungen in einer der Fondsanlage vergleichbaren Höhe zu realisieren.

Der auf regelmäßige Zahlungen verzichtende Fondsanleger beteiligt sich an einem thesaurierenden Fonds. Ein vergleichbarer Direktanleger erwirbt je nach präferierter Ertragsart annahmegemäß entweder Aktien an einem thesaurierenden Zielunternehmen oder zeichnet eine Nullkuponanleihe.

Für die Modellberechnungen wird von den in Tabelle B.2 ausgewiesenen, aus historischen 
Daten $^{39}$ abgeleiteten, Bruttorenditen ${ }^{40}$ deutscher Aktien- und Rentenfonds ausgegangen.

Tabelle B.2: Zusammensetzung der Gesamtrenditen

\begin{tabular}{|c|c|c|c|c|}
\hline & & Aktienfonds & Rentenfonds & Durchschnitt \\
\hline & Dividenden- bzw. Zinsrendite & $2,78 \%$ & $1,55 \%$ & $2,17 \%$ \\
\hline \multirow[t]{3}{*}{+} & Kursrendite & $3,25 \%$ & $2,82 \%$ & $3,04 \%$ \\
\hline & davon auf realisierte Kursgewinne entfallend & $1,62 \%$ & $1,41 \%$ & $1,52 \%$ \\
\hline & davon auf unrealisierte Kursgewinne entfallend & $1,62 \%$ & $1,41 \%$ & $1,52 \%$ \\
\hline & Gesamtrendite des Fonds & $6,03 \%$ & $4,37 \%$ & $5,20 \%$ \\
\hline
\end{tabular}

Die Kursgewinnrendite wird mangels verfügbarer Durchschnittswerte hälftig als auf realisierte und unrealisierte Kursgewinne entfallend angenommen. Die ausgewiesenen Renditen werden über die gesamte Haltedauer konstant gehalten. Da ein Unterschied in der Rendite nach Steuern allein dann als ausschließlich steuerlich verursacht angesehen werden kann, wenn die Anlage in Aktien und Anleihen vor Steuern gleichermaßen rentabel ist, finden in das Modell die jeweiligen (für Aktien und Anleihen identischen) Durchschnittsrenditen Eingang. Um daneben die Vergleichbarkeit zwischen Fonds- und Direktanlage zu wahren, gelten die ausgewiesenen Durchschnittsrenditen für die Direktanlage in Aktien und Anleihen entsprechend.

Es wird unterstellt, dass der Anleger neben den Erträgen aus der Kapitalanlage in jeder Periode zusätzlich über ein zu versteuerndes Einkommen in Höhe von 100.000 Euro (Variante 1) oder 50.000 Euro (Variante 2) verfügt, das im Privatvermögensfall vollständig auf Einkünfte aus nichtselbständiger Arbeit im Sinne des $§ 19$ EStG und im Betriebsvermögensfall auf Einkünfte aus Gewerbebetrieb im Sinne des § 15 EStG zurückgeführt wird. Dieses Sockeleinkommen geht direkt in die Bemessungsgrundlage für die Einkommen- und Gewerbesteuer ein, um zu vermeiden, dass der persönliche Steuersatz des Anlegers im Fall der Anwendung des progressiven Einkommensteuertarifs nicht unrealistisch niedrig ausfällt. Würden nur die Kapitalerträge berücksichtigt, führte die im Rahmen der Günstigerprüfung durchgeführte Veranlagung unter den getroffenen Annahmen über die Rendite der Kapitalanlage regelmäßig zu einer niedrigeren Steuerbelastung als die Abgeltungsteuer. ${ }^{41}$ Zur Ermittlung der effektiven Steuerbelastung des Anlegers wird das

\footnotetext{
39 Für Aktienfonds vgl. MSCI Barra World Index („Gross“-Variante für Gesamtrendite und „Price“-Variante für Kursgewinnrendite). Beim Rentenfonds dient mangels Daten ersatzweise der geometrische Mittelwert der Gesamtrendite deutscher Bundesanleihen (Quelle: Deutsche Bundesbank) als Ausgangspunkt. Die Aufteilung auf Zins- und Kursgewinnrendite richtet sich nach dem Coupon/Yield-Verhältnis, das per 8. 8. 2013 im FTSE Germany Government Bond Index ausgewiesen wurde. Relevanter Zeitraum jeweils Januar 1998 bis Juli 2013.

40 Die Bezeichnung „Bruttorendite“ meint die Rendite vor Steuern der Fonds- und Anlegerebene. Es handelt sich allerdings insoweit um eine Nettorendite, als sie bereits um Steuern des Zielunternehmens, in das der Direktanleger bzw. der Fonds investiert, gemindert ist. Es wird bei Direkt- und Fondsanlage von identischen Nachsteuerergebnissen auf Unternehmensebene ausgegangen.

41 Möglicherweise käme es wegen des Grundfreibetrags bei der Einkommensteuer zu überhaupt keiner Besteuerung.
} 
Sockeleinkommen wieder ausgeblendet, indem in die Berechnung nur der anteilig auf die steuerpflichtigen Kapitalerträge entfallende Teil der gesamten Steuerzahlung einfließt. Für den Anleger mit Wertpapierbesitz im Betriebsvermögen wird ein Gewerbesteuerhebesatz von 368 Prozent zugrundegelegt. ${ }^{42}$ Betreffend die Werbungskosten-Pauschbeträge im Sinne von $\S$ 9a Satz 1 Nr. 1 lit. a EStG (Arbeitnehmer-Pauschbetrag) und § 20 Abs. 9 EStG (Sparer-Pauschbetrag) wird unterstellt, dass sie vom steuerpflichtigen Anleger bereits aufgrund anderer Sachverhalte ausgeschöpft sind und damit im Rahmen der Berechnungen der effektiven Steuerbelastungen des Fonds- und Direktanlegers vernachlässigt werden können.

Alle zahlungswirksamen Erträge gelten als in der Periode zugeflossen, in der ihre wirtschaftliche Verursachung liegt. Folglich erhöhen Steuererstattungen und mindern Steuernachzahlungen die Einnahmen des Anlegers bereits in der Periode, auf die sie sich beziehen. Zinseffekte, die aus den exakten Zahlungszeitpunkten in der jeweiligen Periode resultieren, werden daher nicht berücksichtigt. Für den Fall der Ausschüttung an den Anleger wird angenommen, dass diese jeweils zum Jahresende erfolgt. In der letzten Periode fließt sie dem Investor unmittelbar vor Veräußerung der Wertpapiere zu.

\subsection{Relative steuerliche Vorteilhaftigkeit zwischen Direktanlage und Fondsanlage nach geltendem Recht}

\subsubsection{Kapitalanlage im Privatvermögen}

Vergleicht man für Zwecke einer Bestandsaufnahme des Status quo die aus dem geltenden Recht folgenden effektiven Steuerbelastungen im Privatvermögen eines Anlegers in Szenario 1 und 2, wird zunächst erkennbar, dass sich die Steuerbelastungen von Direktanlage und Fondsanlage im Ausschüttungsfall entsprechend der Idee einer transparenten Besteuerung gleichen und mit einem Wert von jeweils 25,81 Prozent betragsmäßig geringfügig unter der tariflichen Steuerbelastung liegen (Abbildung B.1), was auf positive Zinseffekte infolge der erst am Ende des Anlagezeitraums eintretenden steuerlichen Erfassung aller sich bis zum Veräußerungszeitpunkt zeitanteilig angesammelten unrealisierten Kursgewinne im Wertpapierportfolio des Direktanlegers oder Fonds zurückzuführen ist. Durch die Thesaurierung der Erträge lässt sich ferner in beiden Anlagealternativen eine Reduktion der effektiven Steuerbelastung erreichen. Betrachtet man nur die Direktanlage, beträgt die Differenz zwischen den Steuerbelastungen im Ausschüttungsfall

42 Dieser entspricht dem durchschnittlichen Hebesatz aller Gemeinden in Deutschland für das Jahr 2012. Quelle: Eigene Berechnungen auf Basis der amtlichen Statistik; vgl. Destatis, 2012. 
Abbildung B.1: Effektive Steuerbelastungen von Direkt- und Fondsanlage im Privatvermögen nach geltendem Recht

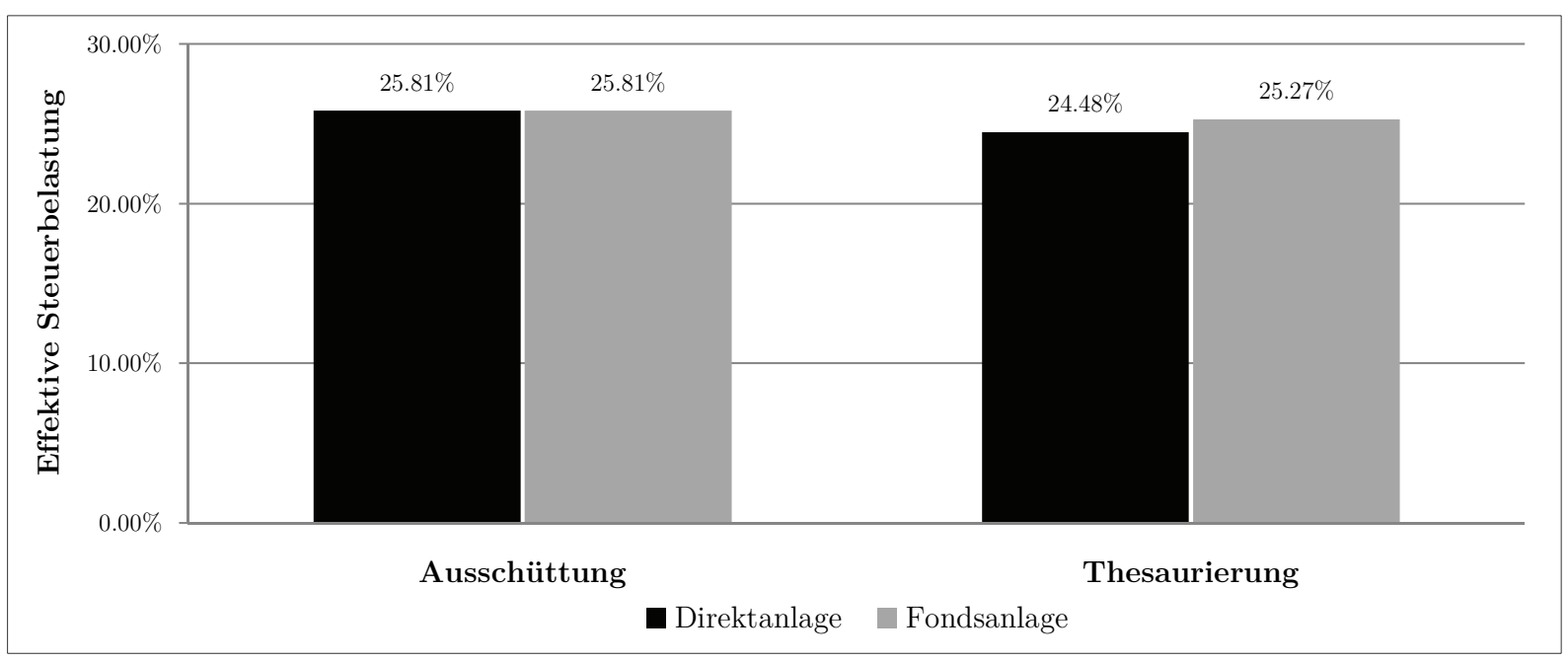

(25,81 Prozent) und im Thesaurierungsfall (24,48 Prozent) 1,33 Prozentpunkte; sie gibt den reinen Steuerstundungseffekt wieder. Die Anlage in einen Thesaurierungsfonds ist unter den getroffenen Annahmen effektiv mit 25,27 Prozent belastet. Die Mehrbelastung von 79 Basispunkten gegenüber der Direktanlage wird durch die investmentsteuerrechtliche Zuflussfiktion des $\S 2$ InvStG verursacht, wonach ausschüttungsgleiche Erträge auch im Thesaurierungsfall jährlich einem Kapitalertragsteuerabzug auf Fondsausgangsseite für Rechnung des Fondsanlegers unterliegen. Die zeitliche Vorverlagerung eines Teils der Steuerzahlungen, der sich ein vergleichbarer Direktanleger nicht ausgesetzt sieht, geht für den Fondsanleger mit einem negativen Zinseffekt und einer entsprechend geringfügig höheren wirtschaftlichen Steuerbelastung einher.

\subsubsection{Kapitalanlage im Betriebsvermögen}

Werden die Wertpapiere des Anlegers unter sonst gleichen Bedingungen in einem Betriebsvermögen gehalten, wirkt sich die relative Gewichtung von Aktien und Anleihen im Anlageportfolio auf die effektive Steuerbelastung aus. Ursächlich hierfür ist die lediglich auf Erträge aus Dividendenpapieren gewährte und damit nur eingeschränkt mögliche Inanspruchnahme des Teileinkünfteverfahrens. Die für den vermögenden Investor (Szenario 1) ermittelten aktienanteilsabhängigen effektiven Steuerbelastungen stellt Abbildung B.2 dar. Der fallende Verlauf der Geraden bringt die steuerliche Privilegierung von Dividenden- gegenüber Zinserträgen grafisch zum Ausdruck. Es zeigt sich, dass nach geltendem Recht auch bei im Betriebsvermögen gehaltenen Kapitalanlagen im Ausschüttungsfall eine steuerliche Gleichstellung von Direkt- und 
Fondsanlage gegeben ist. Ein betrieblicher Kapitalanleger mit ausgeprägter Anleiheorientierung wird steuerlich deutlich stärker belastet als ein vergleichbarer Anleger mit Wertpapierbesitz im Privatvermögen. Für ein rein anleihebasiertes Anlageportfolio ergibt sich eine Steuerbelastung von 37,70 Prozent, das sind 11,89 Prozentpunkte mehr als im Privatvermögen. Die große Belastungsdifferenz geht zentral auf die Progressionswirkung des Einkommensteuertarifs zurück, da im Betriebsvermögen nicht die günstige Abgeltungsteuer zur Anwendung kommt. Eine steuerliche Gleich- oder Besserstellung von Kapitalanlagen im Betriebsvermögen gegenüber solchen im Privatvermögen stellt sich unter den gesetzten Modellannahmen erst ab Aktienquoten jenseits der 70 Prozent ein. Ein reines Aktienportfolio, das im Betriebsvermögen gehalten wird, führt im Vergleich zur Anlage im Privatvermögen zu einer auf das Teileinkünfteverfahren zurückzuführenden Ersparnis von 3,99 Prozentpunkten. Ein Blick auf die Berechnungsergebnisse für den Thesaurierungsfall zeigt betreffend dessen steuerlicher Vorteilhaftigkeit im Vergleich zur Ausschüttungsalternative ein vom Privatvermögensfall abweichendes Bild: Eine langfristige Wertzuwachsstrategie im Betriebsvermögen führt zu einer steuerlichen Schlechter- statt Besserstellung des Anlegers. Hierbei stellen sich für den Fondsanleger verhältnismäßig geringfügige Belastungsnachteile von 0,56 Prozentpunkten für reine Anleiheinvestments und 0,15 Prozentpunkten für reine Aktieninvestments ein, während sich der Direktanleger entsprechenden Mehrbelastungen zwischen 2,4 und 0,84 Prozentpunkten gegenübersieht. Die höheren Steuerbelastungen im Thesaurierungsfall resultieren aus der Progression des Einkommensteuertarifs, die sich beim Fondsanleger wegen des infolge der unterjährig aus dem Fondsvermögen gezahlten Abzugsteuern geringeren Veräußerungsgewinns relativ schwächer auswirkt als beim Direktanleger.

Die benannten Zusammenhänge gelten im Wesentlichen auch für Szenario 2, in dem ein relativ weniger vermögender Anleger betrachtet wird. Eine grafische Aufbereitung der Ergebnisse stellt Abbildung B.3 bereit. Aufgrund der annahmegemäß geringeren steuerpflichtigen Einkünfte, ist auch der zur Anwendung kommende Grenzsteuersatz nach $\S 32 \mathrm{a}$ EStG niedriger als in Szenario 1, was seinen Niederschlag in geringeren effektiven Steuerbelastungen findet. Der Kurvenverlauf fällt bedingt durch die schwächere Progression im Einkommensteuertarif im Vergleich zu Szenario 1 flacher aus, zahlenmäßig ausgedrückt betragen die Belastungsunterschiede für einen Aktienanteil von null Prozent jeweils knapp zehn Prozentpunkte, während sich für das reine Aktienportfolio nur Differenzen von jeweils gut fünf Prozentpunkten ergeben. 
Abbildung B.2: Effektive Steuerbelastungen von Direkt- und Fondsanlage im Betriebsvermögen nach geltendem Recht (Szenario 1)

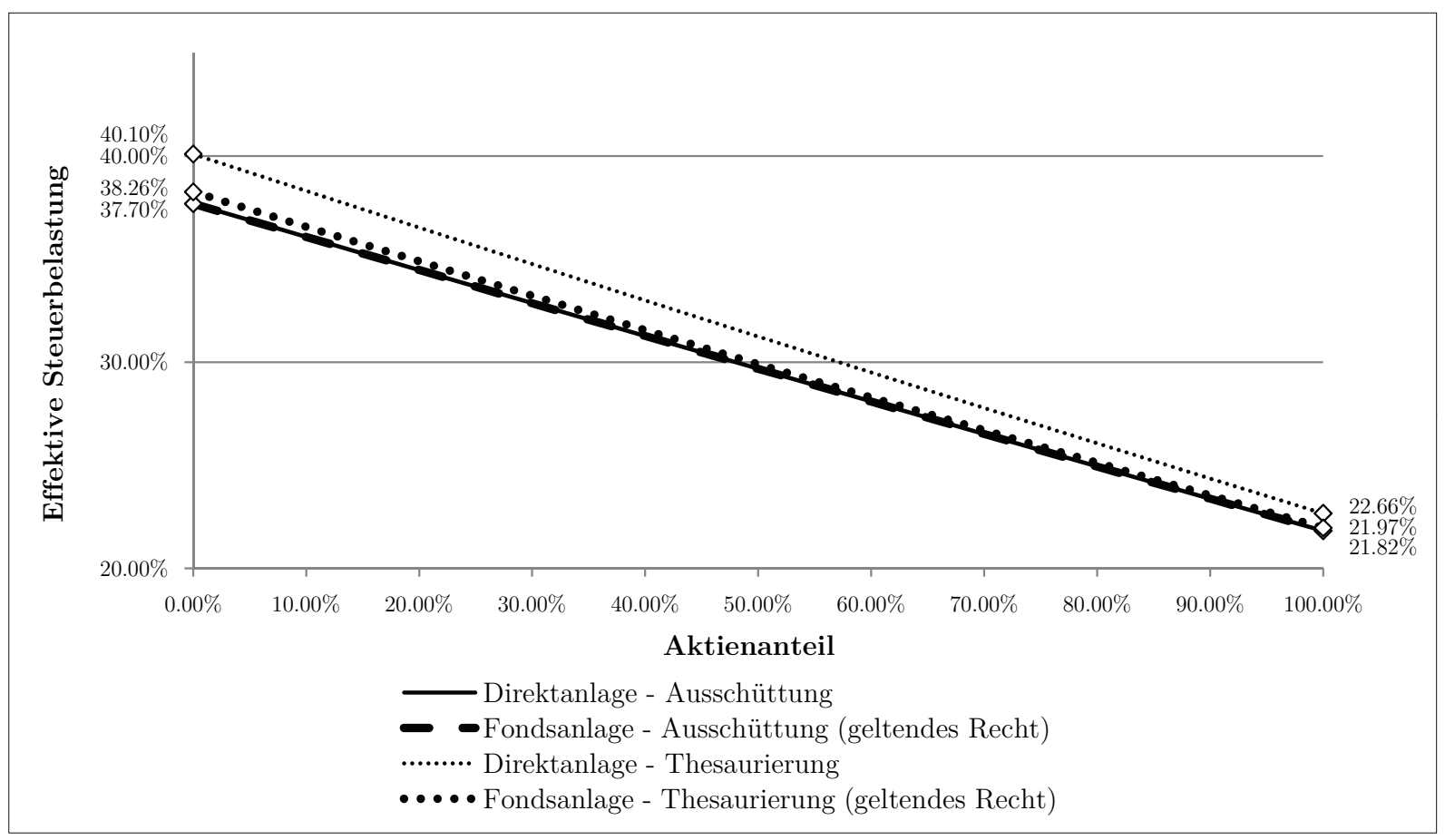

Abbildung B.3: Effektive Steuerbelastungen von Direkt- und Fondsanlage im Betriebsvermögen nach geltendem Recht (Szenario 2)

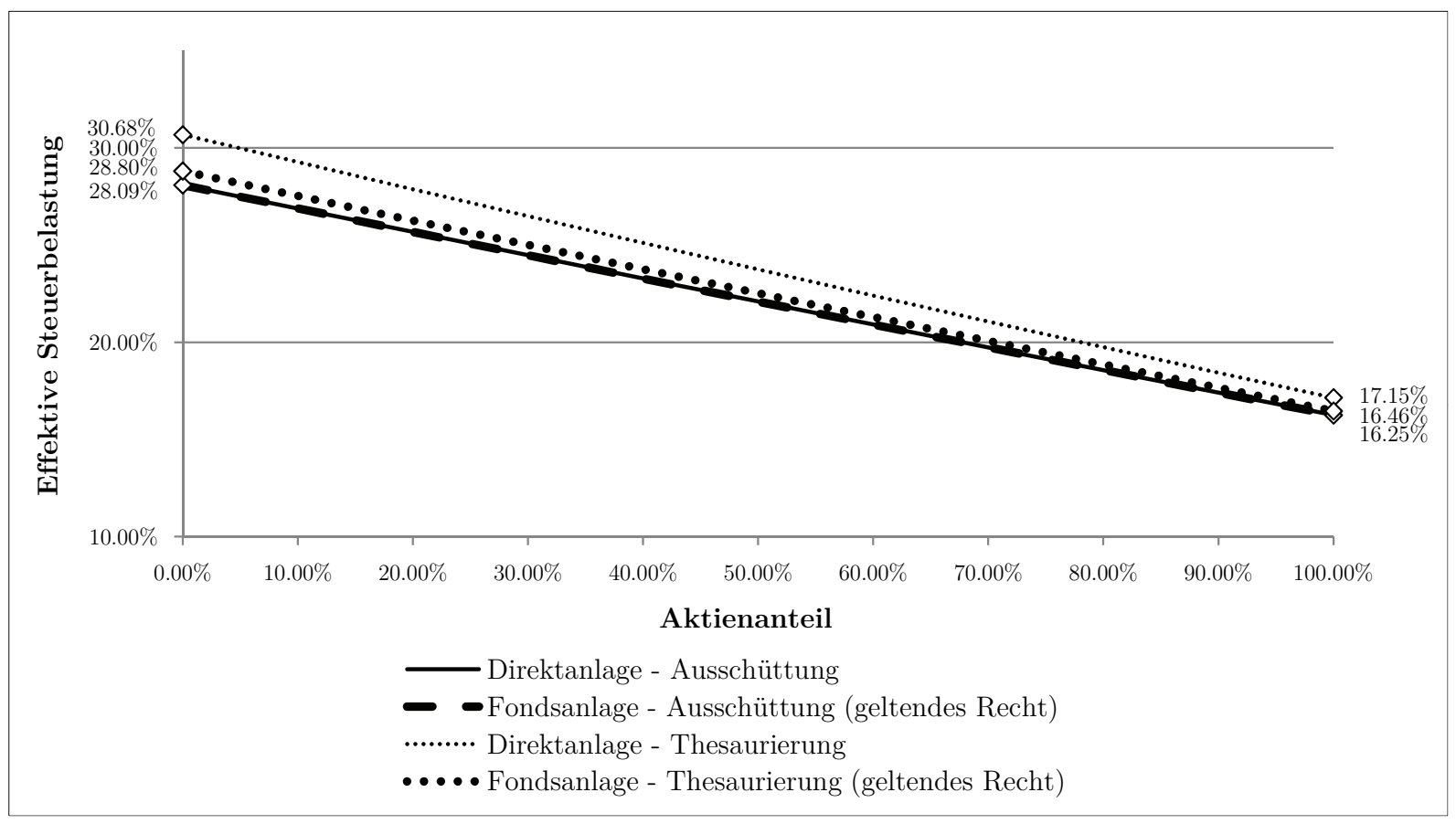




\subsubsection{Zwischenergebnis}

Die Rangfolge der vier untersuchten Sachverhaltskonstellationen in Bezug auf deren effektive Steuerbelastung stellt sich in Abhängigkeit von der Zuordnung der Kapitalanlage zum Privatoder Betriebsvermögen als unterschiedlich dar. Während bei Kapitalanlagen im Privatvermögen die Thesaurierung steuerlich jeweils vorteilhafter ist als die Ausschüttung, trifft im Betriebsvermögen das Gegenteil zu. Sowohl im Privatvermögens- als auch im Betriebsvermögensfall ist die Rangfolge der Anlagealternativen (Direktanlage versus Fondsanlage bei Ausschüttung oder Thesaurierung) von der Vermögenssituation des Anlegers und von der Zusammensetzung des Anlageportfolios unabhängig. Eine steuerliche Gleichbelastung von Direkt- und Fondsanlage ist auf der Grundlage der bestehenden Vorschriften nur im Ausschüttungsfall gegeben. Betreffend den Thesaurierungsfall muss wiederum zwischen Privat- und Betriebsvermögen unterschieden werden. Erfolgt die Anlage im Privatvermögen, ist die Direktanlage steuerlich vorteilhafter als die Fondsinvestition, im Betriebsvermögen dagegen ist das Fondsinvestment relativ geringer belastet als die direkte Kapitalanlage.

\subsection{Reformbedingte Auswirkungen auf die relative steuerliche Vorteilhaftigkeit zwischen Direktanlage und Fondsanlage}

\subsubsection{Kapitalanlage im Privatvermögen}

Die Berechnungsergebnisse für den Ausschüttungsfall zeigen, dass nach einer Umsetzung des Reformvorschlags in seiner vorliegenden Entwurfsfassung einzig die Anlage in einen reinen Rentenfonds unverändert mit derselben effektiven Steuerbelastung wie eine vergleichbare rein anleihebasierte Direktanlage verbunden wäre. Investments in reine Aktienfonds hingegen würden, wenn auch nur geringfügig (+0,04 Prozentpunkte), stärker belastet als die korrespondierende Direktanlagealternative. Unabhängig von der Vermögenssituation des Anlegers zeigt sich, dass entweder überwiegend in Anleihen (Aktienanteil unter 51 Prozent) oder annähernd ausschließlich in Aktien (Aktienanteil über etwa 97 Prozent) investierte Ausschüttungsfonds im Vergleich zu einer Direktanlage mit übereinstimmender Wertpapierzusammenstellung steuerlich effektiv stärker belastet würden. Demgegenüber würde die Fondsanlage unter den gewählten Annahmen bei Aktienanteilen zwischen 51 und circa 97 Prozent gegenüber der Direktanlage aus steuerlicher Sicht an Attraktivität gewinnen. Greift die Aktienteilfreistellung mangels ausreichend hohen Aktienanteils gerade noch nicht (Aktienanteil gleich 50,99 Prozent), stellt sich die bei vollständiger 
Ausschüttung maximal mögliche relative Mehrbelastung des Fondsanlegers im Vergleich zum Direktanleger ein; sie beträgt unter den hiesigen Modellannahmen 250 Basispunkte. Die größte Minderbelastung im Vergleich zur Direktanlage ergibt sich für einen Aktienanteil von genau 51 Prozent und macht hier 68 Basispunkte aus.

Der in einen Thesaurierungsfonds investierte Anleger würde durch eine Reform der Fondsbesteuerung im Vergleich zu einem in Nullkuponanleihen oder Aktien thesaurierender Unternehmen investierten Direktanleger steuerlich bevorteilt. Im Thesaurierungsfall ist die Direktanlage unabhängig vom Aktienanteil effektiv mit 24,48 Prozent Steuern belastet, während sich auf der Grundlage der Modellannahmen für die Fondsanlage je nach Aktienanteil eine Bandbreite effektiver Steuerbelastungen von 17,20 bis 20,64 Prozent (Szenario 1) beziehungsweise 17,98 bis 21,63 Prozent (Szenario 2) ergibt. Verglichen mit dem Status quo, in dem die Direktanlage einer geringeren effektiven Steuerbelastung als die Fondsanlage unterliegt (siehe Abschnitt 4.2.1), bewirkt die Anwendung der geplanten Rechtsvorschriften auf die Modellinvestments insoweit folglich eine Vorteilhaftigkeitsumkehr. Ursächlich hierfür ist zum einen, dass die Bemessungsgrundlagen der Einkommensteuer des Anlegers, die im Modell sowohl nach geltendem Recht als auch unter dem Reformentwurf über Quellensteuerzahlungen aus dem Fondsvermögen grundsätzlich abgeltend beglichen wird, weniger hoch ausfallen. Konkret ist die Summe der über die Haltedauer anzusetzenden Vorabpauschalen nach dem Reformentwurf kleiner als die Summe der im Wege der Zuflussfiktion nach geltendem Recht zuzurechnenden ausschüttungsgleichen Erträge. Zum anderen wird für Zwecke der Berechnungen im Reformszenario aus den in Abschnitt 3.3.2 dargelegten Gründen davon abgesehen, im Zuge der Festsetzung des steuerpflichtigen Gewinns, den der Anleger aus der Veräußerung der Fondsanteile erzielt, eine gewinnerhöhende Hinzurechnung der während der Haltedauer des Fonds aus dem Fondsvermögen gezahlten Quellensteuern vorzunehmen. Da gleichzeitg aber alle während des Anlagezeitraums angesetzten Vorabpauschalen die Bemessungsgrundlage mindern, kommt dies im Ergebnis einem begünstigend wirkenden Abzug der Quellensteuern gleich, der nach geltendem Recht nicht möglich ist. ${ }^{43}$ Bedingt durch die Körperschaftsteuerpflicht des Fonds auf inländische Dividenden steigt die effektive Steuerbelastung mit zunehmendem Aktienanteil an, wobei sich ab Aktienanlagequoten des Fonds von 51 Prozent auf Ebene des Anlegers die 20-prozentige Freistellung aller auf dessen Ebene steuerpflichtigen Erträge entlastend auswirkt. Im Übrigen zeigen die Berechnungsergebnisse für den Thesaurierungsfonds eine durchweg circa einprozentige effektive Mehrbelastung des weni-

$\overline{43}$ Vgl. auch die Ausführungen in Büttner \& Mücke, 2010, Rn. 134. 
ger vermögenden Anlegers gegenüber dem vermögenden Anleger an. Verursacht wird dies durch den Vorabpauschale-Freibetrag, welcher der grundsätzlichen proportionalen Besteuerung eine nicht-lineare Komponente beifügt. Während die der Abzugsbesteuerung auf Fondsausgangsseite unterliegenden Vorabpauschalen in Szenario 1 als Ausfluss der Modellannahmen um den Faktor zehn größer sind als in Szenario 2, werden sie in beiden Fällen um den Vorabpauschale-Freibetrag in Höhe von konstant 300 Euro gemindert. Wegen des relativ schwächeren Entlastungseffekts des Freibetrags in Szenario 1 sind insoweit relativ größere Kapitalertragsteuerzahlungen aus dem Fonds zu leisten. Entsprechend ist auch der der Veräußerungsgewinnbesteuerung unterliegende Gewinn am Ende der Haltedauer relativ kleiner als in Szenario 2. Die Summe der während der Haltedauer bereits versteuerten Vorabpauschalen ist wie nachträgliche Anschaffungskosten vom Veräußerungsgewinn vor Steuern abzusetzen, wobei, gemessen am Veräußerungsgewinn vor Steuern, in Szenario 1 ein geringfügig größerer Anteil in Abzug gebracht werden kann als in Szenario 2. Die Bemessungsgrundlage als Differenzgröße fällt daher in Szenario 1 verhältnismäßig geringer als in Szenario 2 aus. Folglich ist auch die Steuerabschlusszahlung, die sich aus der Anwendung des proportionalen Tarifs der Abgeltungsteuer auf die Bemessungsgrundlage ergibt, relativ kleiner.

Eine graphische Zusammenfassung der diskutierten Berechnungsergebnisse bietet Abbildung B.4 an.

Abbildung B.4: Effektive Steuerbelastungen von Direkt- und Fondsanlage im Privatvermögen unter dem Reformszenario

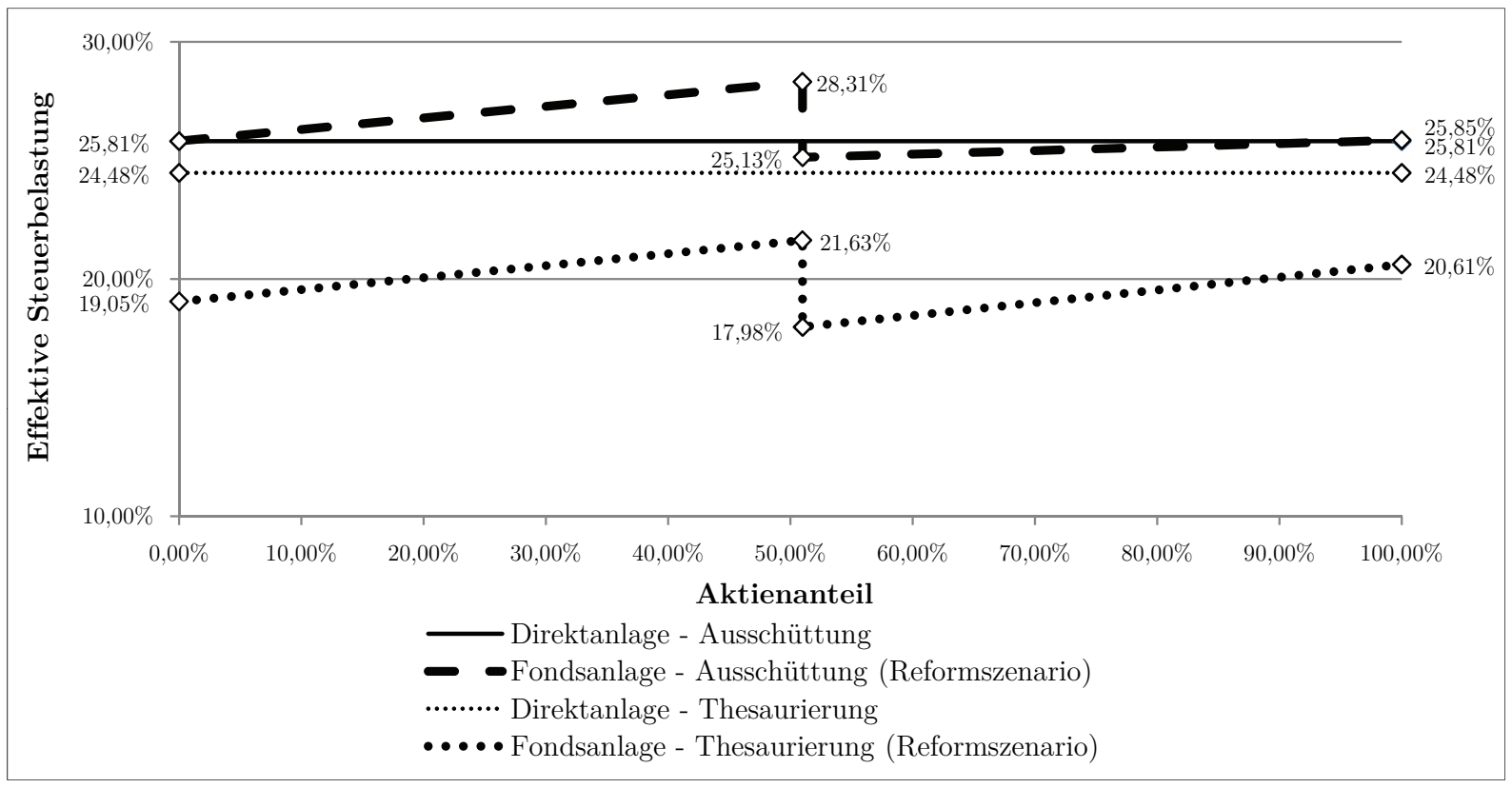




\subsubsection{Kapitalanlage im Betriebsvermögen}

Betrachtet man den Fall der Kapitalanlage im Betriebsvermögen und lässt dabei die rein anleihebasierten Investitionen, deren effektive Steuerbelastungen durch den Reformentwurf unberührt blieben, unberücksichtigt, machen die den Ausschüttungsfall betreffenden Berechnungen sowohl für Szenario 1 als auch für Szenario 2 deutlich, dass Fondsinvestments unter dem vorgeschlagenen Besteuerungsregime grundsätzlich mit höheren effektiven Steuerbelastungen belastet wären als vergleichbare Direktanlagen. Die Berechnungen für das geltende Recht in Abschnitt 4.2.2 weisen dagegen eine steuerliche Gleichbelastung beider Anlagealternativen aus. Ist das Fondsvermögen zu weniger als 51 Prozent in Aktien investiert, würde sich unter dem Reformszenario ein positiver Zusammenhang zwischen der effektiven Steuerbelastung der Fondsanlage und der Höhe des Aktienanteils einstellen; erst für Aktienanteile ab 51 Prozent würde dieser Zusammenhang schwach negativ. Demgegenüber wird die Direktanlage unter steuerlichen Gesichtspunkten generell umso günstiger, je mehr Aktien der Fonds in seinem Portfolio hat (Abbildung B.2 und Abbildung B.3). Anders als der Direktanleger, soll der Fondsanleger nach der Reform nicht länger von der entlastenden Wirkung des Teileinkünfteverfahrens profitieren. Noch dazu würde auf den inländischen Dividendenerträgen des Fonds zusätzlich Körperschaftsteuer lasten. Zwar ist mit der Aktienteilfreistellung auf Anlegerebene ein Kompensationsinstrumentarium vorgesehen, diese käme allerdings nur unter der Voraussetzung zum Tragen, dass mindestens 51 Prozent des Fondsvermögens in Aktien investiert sind. Entsprechend entwickeln sich die effektiven Steuerbelastungen der Direkt- und Fondsanlage, wie in Abbildung B.5 und Abbildung B.6 veranschaulicht, bis zu einem Aktienanteil von 51 Prozent zunächst in entgegengesetzte Richtung, bevor im weiteren Verlauf die Aktienteilfreistellung Wirkung entfaltet und auch die effektive Steuerbelastung der Fondsanlage mit zunehmendem Aktienanteil zurückgeht.

Wie bereits für den Ausschüttungsfall hätte eine Reform der Fondsbesteuerung nach dem Muster des vorgelegten Entwurfs auch für den Thesaurierungsfall zur Konsequenz, dass die sich im Einzelfall einstellende Ausprägung der relativen steuerlichen Vorteilhaftigkeit zwischen Direktund Fondsanlage Ausfluss des Zusammenwirkens von Teileinkünfteverfahren beim Direktanleger einerseits sowie Körperschaftsteuer und Aktienteilfreistellung beim Fondsanleger andererseits wäre. Weitergehende Komplexität gewinnt diese Frage unter dem Reformentwurf dadurch, dass bei Thesaurierung eine (zumindest partielle) steuerliche Erfassung auch der tatsächlich nicht ausgeschütteten Erträge des Fonds im Wege der Besteuerung von Vorabpauschalen erfolgen soll. Für den untersuchten Modellinvestor hat dies zur Folge, dass sich in Abhängigkeit von dem 
Abbildung B.5: Effektive Steuerbelastung von Direkt- und Fondsanlage im Betriebsvermögen unter dem Reformszenario (Szenario 1)

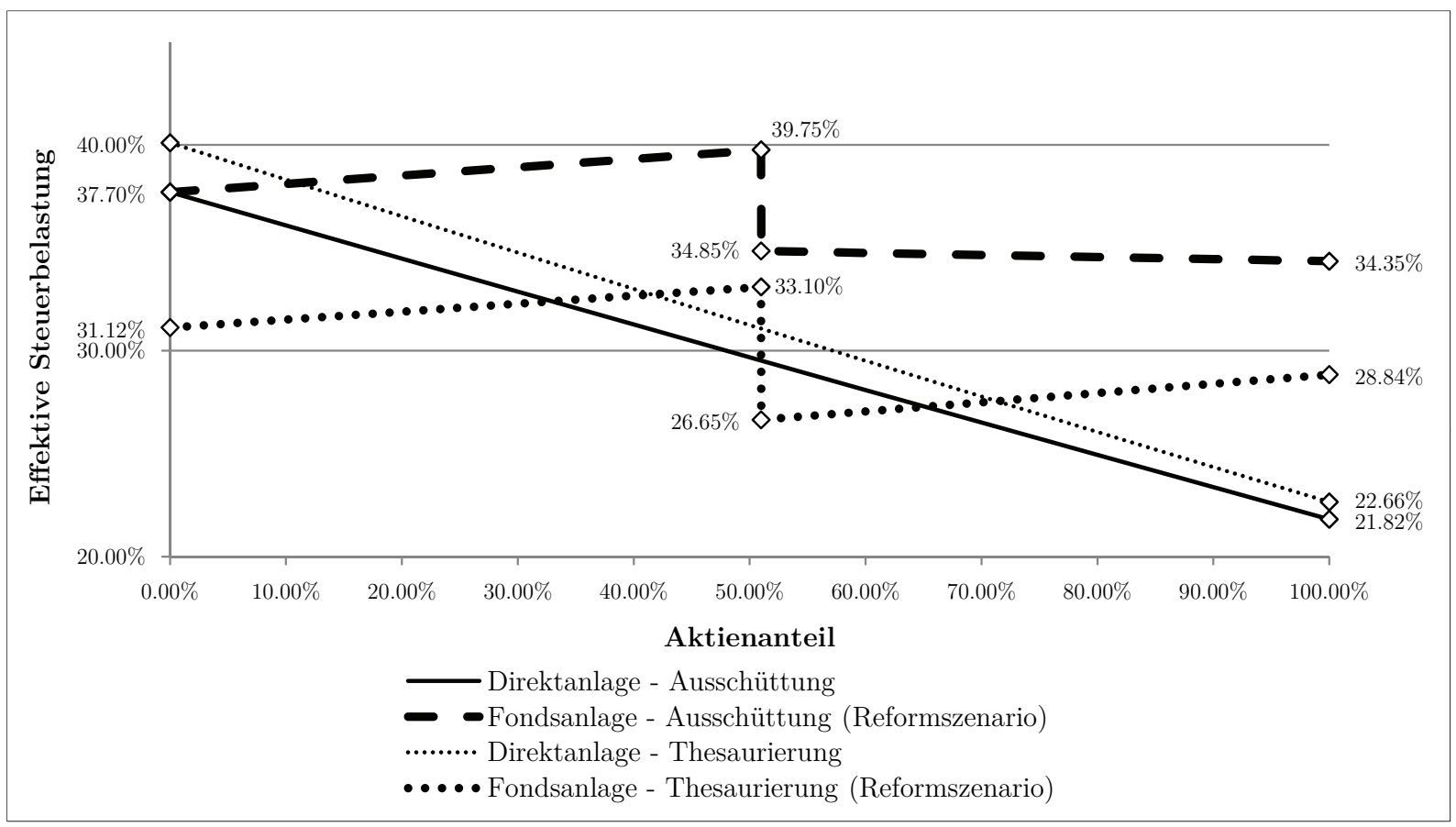

Aktienanteil und dem durch die Vermögenssituation des Investors determinierten persönlichen Steuersatz die Direktanlage im Vergleich zur Fondsanlage einzelfallabhängig entweder als steuerlich günstiger oder ungünstiger darstellen würde. Im vorliegenden Modellsachverhalt wäre dem vermögenden Investor aus steuerlicher Sicht die Fondsanlage für Aktienanteile in den Bereichen null bis 41,5 Prozent und 51 bis 71 Prozent anzuraten (vergleiche Abbildung B.5), während sich für den weniger vermögenden Investor größere Bandbreiten von null bis knapp 48 Prozent und 51 bis circa 72,5 Prozent identifizieren lassen (vergleiche Abbildung B.6). ${ }^{44}$ Tendenziell gilt für den Thesaurierungsfall damit, dass Anleger nach einer Reform der Fondsbesteuerung stark anleiheorientierte Kapitalanlagen über Investmentfonds vornehmen sollten, stark aktienorientierte Kapitalanlagen hingegen bei direkter Anlage steuerlich günstiger wären.

\subsubsection{Zwischenergebnis}

Die Veranlagungssimulation des Modellsachverhalts unter Zugrundelegung des Reformvorschlags zur Investmentfondsbesteuerung macht deutlich, dass eine tatsächliche Umsetzung dieses

\footnotetext{
44 Die angegebenen Intervallgrenzen sind jeweils Näherungswerte und haben nur unter den gesetzten Modellannahmen Gültigkeit.
} 
Abbildung B.6: Effektive Steuerbelastung von Direkt- und Fondsanlage im Betriebsvermögen unter dem Reformszenario (Szenario 2)

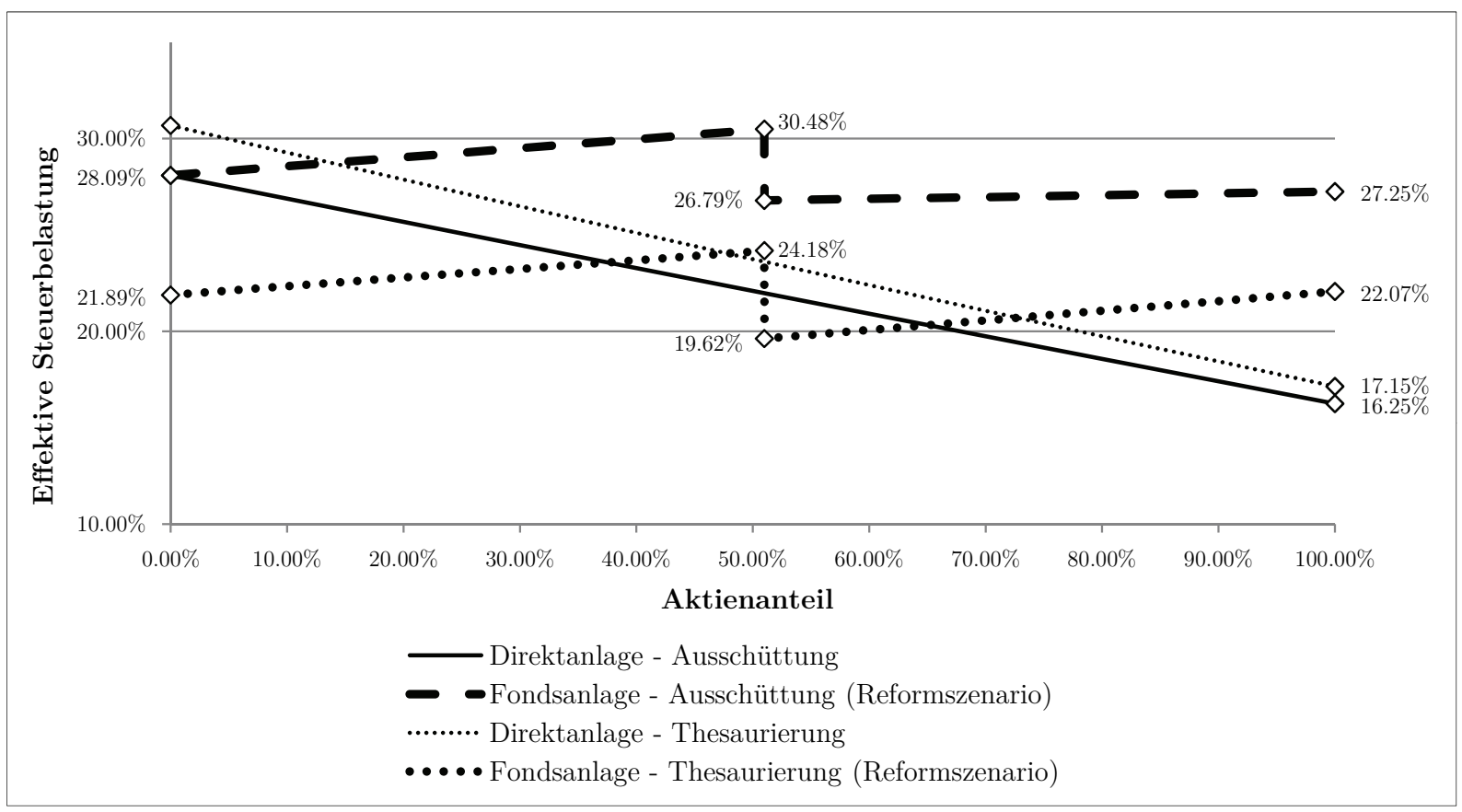

Konzepts ${ }^{45}$ dem bereits nach geltendem Recht verbreitet bestehenden Auseinanderdriften der steuerlichen Behandlung von Direkt- und Fondsanlagen weiteren Vorschub leisten würde. Insbesondere wären beide Anlagealternativen (auch) im Ausschüttungsfall regelmäßig nicht länger, wie bisher, mit der gleichen Steuerbelastung verbunden. Für eine Prüfung der steuerlichen Vorteilhaftigkeit zwischen direkter und indirekter Kapitalanlage müsste zudem in weitaus größerem Maße als nach geltendem Recht den in der konkret vorliegenden Entscheidungssituation gegebenen Einflussgrößen der Vermögenssituation des Anlegers und der Zusammensetzung des Anlageportfolios Beachtung geschenkt werden. Dies gilt insbesondere für im Betriebsvermögen gehaltene Kapitalanlagen.

\subsection{Reformbedingte Auswirkungen auf die Steuerbelastung von Fondsanlagen}

Im bisherigen Verlauf der Untersuchung lag der Fokus des Interesses auf der Frage, welche Folgen aus einer Umsetzung des Konzeptionsentwurfs in geltendes Recht für das Verhältnis von Direkt- und Fondsanlagen aus Steuerbelastungssicht zu erwarten sind. Abschließend soll be-

45 Der vorgeschlagene Konzeptionsentwurf weist unter systematischen Gesichtspunkten weitgehende Ähnlichkeiten mit den Besteuerungsregimen insbesondere Frankreichs und Italiens auf. Allein in Bezug auf die angestrebte Doppelbesteuerung der inländischen Dividenden gilt dies nicht; insoweit erinnert der Vorschlag der Arbeitsgruppe an Teile der Steuersysteme in Japan, Spanien, den USA und dem Vereinigten Königreich. Vgl. hierzu im Einzelnen Oestreicher \& Hammer, 2014, S. 52-56. 
Abbildung B.7: Reformbedingte Belastungsdifferenzen der Fondsanlage im Privatvermögen

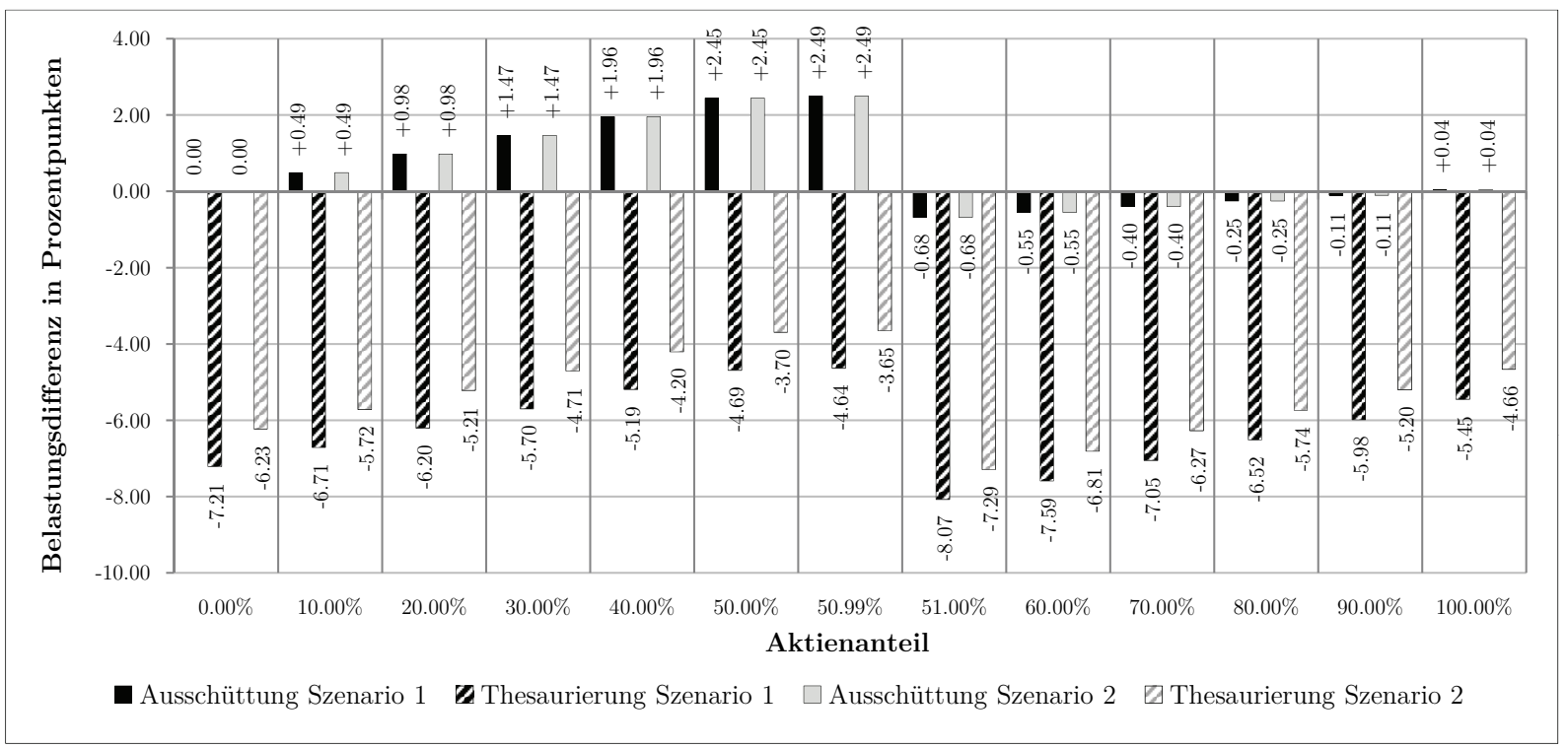

leuchtet werden, unter welchen Voraussetzungen und in welchem Ausmaß sich durch die mögliche Reform die Steuerbelastung von Fondsanlagen ändern würde. Aus diesen Resultaten lassen sich Erkenntnisse über potentielle Gewinner und Verlierer dieser Reform innerhalb der Fondsbranche gewinnen.

Die in Prozentpunkten gemessenen, reformbedingten Veränderungen der effektiven Durchschnittssteuerbelastung des Modellanlegers bei Fondsanteilsbesitz im Privatvermögen weist Abbildung B.7 aus. Auffällig ist die durchweg einsetzende Entlastung von in Thesaurierungsfonds investierten Anlegern, wobei die Entlastung für den vermögenden Investor relativ stärker ausfällt als für den weniger vermögenden. Für die Ausschüttungsfonds zeigt sich erstens, dass Anlagen in die Reinformen Rentenfonds und Aktienfonds nicht beziehungsweise nur marginal höher belastet würden als im Status quo. Im Übrigen gilt, dass die effektiven Steuerbelastungen von Investitionen in Ausschüttungsfonds mit Aktienanteilsquoten unter 51 Prozent zunehmen würden, während in zukünftig steuerlich als „Aktienfonds“ qualifizierende Ausschüttungsfonds investierte Anleger regelmäßig entlastet würden.

Wie Abbildung B.8 zeigt, würde die modellierte Fondsanlage im Betriebsvermögen nach einer Reform in den überwiegenden Fällen höher als derzeit besteuert. Ausnahmslos von Mehrbelastungen verschont blieben diesbezüglich nur reine Rentenfonds. Eine eher anleiheorientierte Investmentstrategie des Fonds, bei der sich der Aktienanteil im Fondsportfolio auf höchstens etwa ein Drittel beläuft, lässt im Thesaurierungsfall verglichen mit dem geltenden Recht Minderbelastungen erwarten. Gleiches gilt für nur geringfügig mehrheitlich aktienbasierte Fonds 
Abbildung B.8: Reformbedingte Belastungsdifferenzen der Fondsanlage im Betriebsvermögen

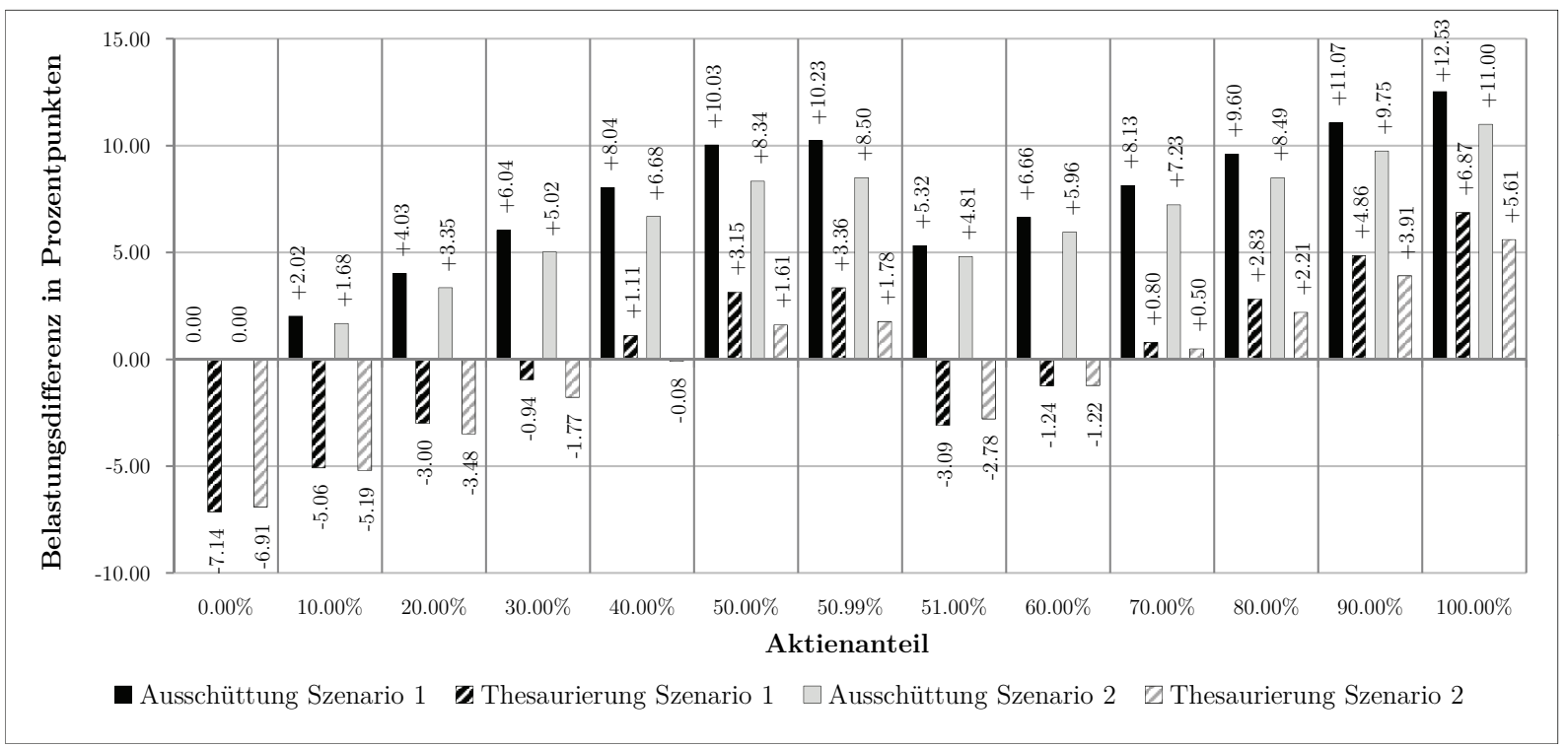

mit Aktienanteilen zwischen 51 und circa 65 Prozent. Demgegenüber würden Anleger in Fonds mit Aktienanteilsquoten zwischen 50 und 50,99 Prozent sowie ab ungefähr 65 Prozent sowohl bei Ausschüttung als auch Thesaurierung durch die Reformkonzeption aus steuerlicher Sicht schlechter gestellt.

\subsection{Mögliche Auswirkungen auf das Steueraufkommen}

Auf der Grundlage der in Abschnitt 4.4 gewonnenen Ergebnisse, lassen sich Tendenzaussagen zu den Aufkommenswirkungen formulieren, die sich bei einer Umsetzung des vorgeschlagenen Reformkonzepts in geltendes Recht einstellen würden. Wegen der unterschiedlichen steuerlichen Konsequenzen der Anlage in Aktien-, Renten- und Mischfonds bedarf es Informationen darüber, wie diese Fondstypen anteilig unter allen in Deutschland domizilierenden Fonds vertreten sind. Hierzu muss zunächst geklärt werden, ab welchen Aktienanteilen in der Realität ein Aktien-, Misch- oder Rentenfonds vorliegt. Bisher wurde unter dem Begriff des (reinen) Aktienfonds ein Fonds verstanden, dessen Aktienanteil sich auf 100 Prozent beläuft; entsprechend galt als (reiner) Rentenfonds ein Fonds mit Aktienanteil von null Prozent. Der in der Realität maßgebliche aufsichtsrechtliche Rahmen jedoch legt die Grenzen großzügig aus; es genügt eine Investitionsquote von mindestens 51 Prozent des Fondsvermögens in die die Fondskategorie bezeichnenden Anlagegegenstände. ${ }^{46}$ Die Statistik der Deutschen Bundesbank weist für die drei Fondskategori-

46 Vgl. BaFin, 2013, Art. 2 Abs. 1. 
en unter anderem das jeweils in Aktien und Anleihen angelegte Vermögen der Fonds aus (Tabelle B.3). ${ }^{47}$

Tabelle B.3: Mittelanlage inländischer Publikumsfonds

\begin{tabular}{lrrrrrr}
\hline & \multicolumn{2}{c}{ Aktienfonds } & \multicolumn{2}{c}{ Mischfonds } & \multicolumn{2}{c}{ Rentenfonds } \\
\hline & \multicolumn{2}{c}{ Absolut } & \multicolumn{2}{c}{ Absolut } & \multicolumn{3}{c}{ Absolut } \\
Angelegtes Vermögen in & in Mio. $€$ & Relativ & in Mio. $€$ & Relativ & in Mio. $€$ & Relativ \\
\hline Aktien & 151.950 & $87,21 \%$ & 51.840 & $20,87 \%$ & 11.070 & $3,15 \%$ \\
\hline Anleihen & 22.291 & $12,79 \%$ & 196.509 & $79,13 \%$ & 340.527 & $96,85 \%$ \\
\hline Summe & 174.241 & $100,00 \%$ & 248.349 & $100,00 \%$ & 351.597 & $100,00 \%$ \\
\hline
\end{tabular}

Näherungsweise wird im Folgenden für Aktienfonds eine Aktieninvestitionsquote von mindestens 90 Prozent angelegt, für Rentenfonds wird insoweit von einer Quote von null Prozent ausgegangen. Mischfonds decken annahmegemäß das verbleibende Intervall zwischen null und 90 Prozent ab. Durch Übertragung dieser Grenzen auf die ermittelten reformbedingten Belastungsdifferenzen (Abbildung B.7 und Abbildung B.8), ergeben sich im Durchschnitt folgende Belastungsdifferenzen in Abhängigkeit von der Kategorie des Fonds und einer Zuordnung der Anteile zum Privat- oder Betriebsvermögen (Tabelle B.4).

Tabelle B.4: Reformbedingte Belastungsdifferenzen, aufgegliedert nach Ausschüttungsverhalten

\begin{tabular}{lcccccc}
\hline & \multicolumn{2}{c}{ Aktienfonds } & \multicolumn{2}{c}{ Mischfonds } & \multicolumn{2}{c}{ Rentenfonds } \\
\hline Ausschüttend (A)/Thesaurierend (T) & A & T & A & T & A & T \\
\hline $\begin{array}{l}\text { Durchschnittliche reformbedingte Belastungs- } \\
\text { differenz im Privatvermögen }\end{array}$ & $-0,03$ & $-5,32$ & $+0,65$ & $-5,84$ & $\pm 0,00$ & $-6,72$ \\
\hline $\begin{array}{l}\text { Durchschnittliche reformbedingte Belastungs- } \\
\text { differenz im Betriebsvermögen }\end{array}$ & $+11,09$ & $+5,31$ & $+6,29$ & $-0,66$ & $\pm 0,00$ & $-7,03$ \\
\hline
\end{tabular}

Nach Tabelle B.3 beläuft sich das Anleihevolumen von Rentenfonds auf über 340,5 Mrd. Euro und damit annähernd 44 Prozent des insgesamt in Aktien und Anleihen angelegten Fondsvermögens. Für diesen unter Aufkommensgesichtspunkten bedeutendsten Fondstyp lässt sich verhältnismäßig klar festhalten, dass dessen Beitrag zum Steueraufkommen durch die Reform sinken würde. Auch bei Mischfonds sticht eine äußerst stark ausgeprägte Anleiheorientierung ins Auge. Zwar wird im Einzelfall der konkrete Aktienanteil relevant sein; dennoch kann davon ausgegangen werden, dass auch in Bezug auf Mischfonds - und somit für insgesamt bereits circa 69,4 Prozent des Gesamtvolumens aller Fondsanlagen in Aktien und Anleihen - häufig die steuerlich relativ günstigen Konsequenzen für Renten maßgeblich sein werden. Im Übrigen hängen

$\overline{47}$ Vgl. Deutsche Bundesbank, 2013, S. 56 f. Ausgeklammert bleiben alle übrigen Vermögenspositionen der Fonds. 
die Aufkommenswirkungen vor allem auch in Hinblick auf die Aktienfonds wesentlich davon ab, ob die Fondsanteile primär im Privat- oder Betriebsvermögen gehalten werden. Werden Fonds überwiegend privat gehalten, besteht für den Fiskus wegen der vor allem bei thesaurierenden Fonds eintretenden Belastungsminderungen das Risiko eines Aufkommensrückgangs. Werden Fonds hingegen überwiegend im Betriebsvermögen gehalten oder überwiegen alternativ die Steuereffekte der aktiendominierten Mischfonds diejenigen der rentendominierten Mischfonds, mag die reformbedingte Mehrbelastung dieser Ertragsart die erwartete Aufkommensminderung bei rentendominierten Fonds überkompensieren. Alles in allem müssen Tabelle B.3 und Tabelle B.4 wohl so gelesen werden, dass das Steueraufkommen nach einer Umsetzung des Reformvorschlags insgesamt zurückgehen kann. Hierbei sind weder Verhaltensreaktionen seitens der Anleger mit Anteilsbesitz im Betriebsvermögen noch erwartbare Umschichtungen in den Fondsvermögen eingerechnet.

\section{Zusammenfassung und Ausblick}

Der vorliegende Beitrag analysiert die Auswirkungen auf die effektive Durchschnittssteuerbelastung von natürlichen Personen, die aus einer möglichen Reform der deutschen Fondsbesteuerung nach Maßgabe des am 24.2. 2012 vorgelegten zweiten Berichtsentwurfs der zuständigen Bund-Länder-Arbeitsgruppe folgen würden. Die geltende Fondsbesteuerung steht unter dem Leitgedanken, direkte Kapitalanlagen und indirekte Kapitalanlagen über Fonds steuerlich gleich zu behandeln. Den Berechnungsergebnissen zufolge wird dieses Ziel im Ausschüttungsfall erreicht. Werden die Kapitalerträge hingegen thesauriert, laufen die Steuerbelastungen von Direktund Fondsanlage unter den gesetzten Modellannahmen auseinander. Im Privatvermögen ist die Direktanlage demnach steuerlich günstiger als die Fondsanlage, im Betriebsvermögen gilt das Gegenteil.

Sollte es zu einer Umsetzung des Reformvorschlags in geltendes Recht kommen, ginge dies mit einer grundlegenden systematischen Neuordnung der Fondsbesteuerung einher. Das Auseinanderdriften der effektiven Steuerbelastungen von Direkt- und Fondsanlagen würde sich verstärken. Mit Blick auf die relative steuerliche Vorteilhaftigkeit zwischen Direkt- und Fondsanlage würden sich darüber hinaus im Vergleich zum Status quo verbreitet Rangfolgeänderungen einstellen. Im Privatvermögen wäre die Direktanlage nur noch im Fall der Ausschüttung bei gleichzeitig überwiegender Anleiheorientierung des Anlageportfolios die unter steuerlichen Ge- 
sichtspunkten vorzugswürdige Alternative. Im Betriebsvermögen würde sich die Direktanlage nur im Ausschüttungsfall als regelmäßig günstiger darstellen, während im Thesaurierungsfall tendenziell nur bei ausgeprägter Aktienorientierung des Anlageportfolios eine Direktanlage vorgenommen werden sollte.

Die isolierte Betrachtung der Belastungswirkungen auf Fondsanlagen lässt zwei Tendenzaussagen zu: Zum einen erführen Thesaurierungsfonds durch die Reform eine verhältnismäßig weit stärkere steuerliche Begünstigung als Ausschüttungsfonds, zum anderen würden Fondsanlagen im Privatvermögen in der Gesamtschau steuerlich besser gestellt als Fondsanlagen im Betriebsvermögen. Insgesamt wird auch deutlich, dass nach einer dem Konzeptionsentwurf folgenden Reform steuerliche Vorteilhaftigkeitsanalysen - insbesondere im Betriebsvermögen - von einer größeren Komplexität geprägt wären und stärker auf den konkreten Einzelfall bezogen erfolgen müssten als bisher. Das von der Arbeitsgruppe ausgerufene Ziel, ein einfacheres Besteuerungskonzept zu entwerfen, vermag der vorgelegte Konzeptionsentwurf damit zumindest aus Sicht eines steuerplanerisch agierenden Anlegers nicht zu erreichen. Zudem kann auf der Basis einer überschlägigen Abschätzung der Aufkommenswirkungen nicht ausgeschlossen werden, dass sich das Aufkommen aus der Besteuerung von Erträgen aus Wertpapier-Publikumsfonds, deren Anlegerkreis auf natürliche Personen beschränkt ist, reduziert. Dabei hat es den Anschein, als solle die angestrebte Vereinfachung der Fondsbesteuerung vornehmlich auf dem Rücken unternehmensbezogener Fondsanleger ausgetragen werden. 


\title{
Kapitel C
}

\section{Location of intra-EU greenfield FDI: Do tax loss offset restrictions matter?}

\begin{abstract}
*
In this study, I empirically examine the impact of inter-period tax loss offset restrictions on location probabilities of multinational enterprises. Using micro-level data on subsidiary establishments in the European Union between 2002 and 2012, my findings from a conditional logit model suggest that neither the imposition of time restrictions on loss carryforwards nor the application of minimum taxation rules exert any statistically significant negative effects on the probability of attracting new foreign-owned subsidiaries. However, multinationals appear to positively respond to the potential availability of loss carryback allowances. The results are robust in showing that the location probability increases by some 6 percentage points if a country provides loss carryback opportunities.
\end{abstract}

Keywords MNE, firm location, corporate taxation, tax loss offset

JEL classification F23, G32, H25, R38

\footnotetext{
I appreciate helpful comments on this paper by Andreas Oestreicher, Jörg-Markus Hitz, Robert Schwager, Reinald Koch, Nico Lehmann and participants of the 2014-15 Research Colloquium in Finance, Accounting, and Taxes at the University of Göttingen. In addition, I received valuable suggestions for improvement during the 2015 Research Seminar on International Business Taxation at the WU Vienna, the 2014 Workshop Empirische Steuerforschung at the ZEW Mannheim and the 2014 EIASM Workshop on Current Research in Taxation at the University of Münster. In this regard, my special thanks to Dhammika Dharmapala, Frank Hechtner (discussant), Jochen Hundsdoerfer, Martin Jacob, Michael Overesch, Matthias Petutschnig (discussant), Jeri K. Seidman and Johannes Voget. Any remaining errors are the author's exclusive responsibility.
} 


\section{Introduction}

In the wake of the expansion of the European Union during the past one and a half decades, the number of companies with access to the Single Market grew considerably. The economic integration simplifies cross-border business activities and increases competition between European countries in attracting foreign direct investment. The determinants of FDI have been analysed extensively (see, e.g., Blonigen (2005) for a survey of related research), and a common finding is that taxes are negatively associated with the locational attractiveness of a country for FDI (in this connection, notable literature reviews are provided by, e.g., Feld \& Heckemeyer (2011) and Tavares-Lehmann, Coelho \& Lehmann (2012)).

The objective of this paper is to study how different levels of strictness regarding tax-loss offset rules influence the decision of MNE for or against locating in a specific country. Empirical insights into that question may be of particular relevance to policy makers, given that in recent years various EU Member States carried out 'tax-cut-cum-base-broadening' reforms by which the statutory corporate income tax rate was reduced while the scope of income to be taxed was extended in order to avoid net revenue losses. One way to achieve a broadening of the tax base is to limit the extent up to which losses may be used over time to reduce taxable profits. Constraining the scope for loss offsetting may consequently imply higher effective tax rates. In light of the fact that the accumulated stock of corporate tax losses across countries grows considerably over time $(\operatorname{OECD}(2011$, p. 16)), it might be expected that the issue of tax loss treatment should matter for firms per se. Yet, it should particularly be taken into consideration in the context of firm location choice since companies are prone to losses especially during their first years of operation.

An empirical examination of this issue may also contribute to improve our understanding how firms anticipate the consequences of tax base provisions when making firm location decisions. Prior research on firm location has brought up ambiguous findings in this respect. Devereux \& Griffith (1998) find that the appropriate measure in explaning intra-European location choices of U.S. multinationals is the effective average tax rate which does not only reflect the statutory tax rate effect but does also account for the effects of tax base provisions. By contrast, for the case of German outbound FDI, Buettner \& Ruf (2007) identify the statutory corporate income tax rate to possess stronger predicitive power in explaning location decisions than the effective average tax rate. Among the wide range of tax base components, depreciation allowances received particular attention so far. Overesch \& Wamser (2009) provide evidence that the present value 
of depreciation allowances in a host country is positively related to the location of German outbound capital-intensive FDI. By contrast, Egger \& Merlo (2011) fail to find any positive correlation between a host country's depreciation allowances and the number of German-owned affiliates in the respective country. An experimental study by Blaufus et al. (2013) suggests that investors overstate the influence of the statutory tax rate on the effective tax burden while they underestimate the impact of the tax base. In light of these heterogenuous findings, further research is needed to elucidate the effectiveness of 'tax-cut-cum-base-broadening' reforms to attract new FDI. By focusing on loss-offset provisions which constitute another key determinant of the tax base, this paper should provide additional insights into this issue.

From the AmADEus database, I compile firm-level data on 31,023 cross-border subsidiary establishments in the European Union between 2002 and 2012 to examine the statistical relation between the probability of a country being chosen as investment location and its local provisions governing tax loss carryover. My baseline results from a conditional logit model point to an elasticity of the probability of location choice with respect to the statutory tax rate of approximately -0.6 which coincides with previous findings (e.g., Barrios et al. (2012) and Hebous, Ruf \& Weichenrieder (2011)). By contrast, the results suggest that MNE do not respond to time restrictions on loss carryforwards in their choice between alternative locations. In addition, I find no robust evidence for an inhibitory effect of minimum taxation provisions that limit the amount of losses carried forward from the past available for deduction against current profits. These findings supplement extant evidence of a subordinate significance of tax base components relative to the statutoy tax rate. On the other hand, my baseline analysis yields indications of an incentivising effect of loss carryback allowances. A country's probability to be chosen as host country increases by some 6 percentage points if it offers the opportunity for a carryback. In this respect, MNE apparentely attach greater weight to an increased degree of flexibility in offsetting losses in the mid-term rather than to relative disadvantages vis-à-vis more mature companies resulting from the likely inability to claim carryback refunds during the start-up phase. These findings are robust against various sensitivity checks.

The paper proceeds as follows. In section 2, I set out a theoretical model of MNE location decisions, discuss expected effects of different tax loss offset provisions on the location choice and derive testable hypotheses. In section 3, I present the empirical methodology. Section 4 outlines the sample selection procedure, contains an overview over the data and provides related descriptive statistics. The findings from the econometric analysis are presented and discussed 
in section 5. Section 6 concludes the study with a summary.

\section{MNE location choice and asymmetric taxation}

\subsection{The OLI framework of MNE activity}

A firm that wants to expand its operations across borders can either engage in foreign direct investment (by creating a new or acquiring an existing foreign enterprise) or carry out direct business activities (e.g., by exporting its domestically produced goods to foreign customers or licensing to or contracting with foreign firms at arm's length). In order to analyse the emergence and geographical structure of MNE activity, Dunning (1977) has developed the 'OLI paradigm' which combines organisational theory, location theory and internalisation theory. The OLI approach states that ownership, location and internalisation advantages must be cumulatively present for a firm to become a multinational enterprise.

Ownership ('O') advantages relate to the fact that new market entrants will generally be placed in a disadvantaged position vis-à-vis their domestic competitors in the host country because the latter have better knowledge of the respective market and business environment. This information asymmetry causes costs for new market entrants and does therefore in principle militate against undertaking FDI. However, if a firm can overcome this cost burden because it is able to derive market power from some kind of proprietary asset it owns or competencies it has (Neary (2008, p. 473) mentions 'headquarter services' like managerial structures, patents or marketing skills in this regard which can be summarised under the term 'knowledge capital' as proposed by Markusen (1995)), foreign market entry by means of FDI may nevertheless be considered a worthy alternative to direct business activity.

Location ('L') advantages answer the question of where firms choose to locate their FDI. In this respect, the motivation for why a firm opts to locate its investment in a specific foreign country rather than at home is of particular relevance. Horizontally integrated firms produce identical goods or offer identical services in different countries. Their motivation for FDI is to achieve proximity to consumers in multiple markets in order to avoid barriers to trade. Horizontallyintegrated firms will tend to prefer FDI over exports if trade costs are high (for instance, due to tariffs or transportation costs between the home and host country) relative to the costs arising from running a direct investment. Furthermore, the larger the host market the more attractive is the country for horizontal FDI. By contrast, vertical FDI is undertaken to decrease production 
costs. MNE of this kind aim at lowering production costs by separating production into stages and conducting specific production activities in countries that allow for the most cost-efficient implementation of these activities. ' $\mathrm{L}$ ' advantages to which vertically-integrated MNE attach specific weight are therefore factor input costs. However, transportation costs are relevant to vertical FDI as well because the foreign-produced intermediate goods need to be transferred upstream or downstream the production chain.

Finally, internalisation ('I') advantages cause MNE to not to outsource their cross-border operations but rather to internalise existing ownership and location externalities. Dunning (2000, p. 179) states that "as long as the transaction and coordination costs of using external arm's length markets in the exchange of intermediate products, information, technology, marketing techniques, etc. exceed those incurred by internal hierarchies, then it will pay a firm to engage in fdi, rather than conclude a licensing or another market related agreement with a foreign producer."

\subsection{Tax loss offset limitations as location disadvantages}

Consider a profit-oriented firm $i$ that wants to exploit its $\mathrm{O}$ and I advantages by means of establishing a new enterprise abroad. The firm faces a set of $J=j^{1}, \ldots, j^{J}$ alternative, yet mutually exclusive, potential locations for its investment. Each location features specific legal, economic and social framework conditions for doing business that influence the financial return from the investment, denoted by $\pi$. Lacking perfect foresight, the firm forms expectations about the future based on information available at the time of the decision-making, denoted by $t$. Formally, the expected profits from investing in host country $j^{\prime}$ can be expressed as a function of a vector of choice-specific variables $\left(\mathbf{x}_{t, j^{\prime}}\right): \pi\left(\mathbf{x}_{t, j^{\prime}}\right)$. Ceteris paribus, the investing firm will locate its subsidiary company in country $j^{*}$ rather than in any other country $j^{\prime} \neq j^{*} \in J$ if the expected profits are likely to be maximised in $j^{*}$. With $I(\cdot)$ as indicator function, this can be formally expressed by:

$$
I\left(y=j^{*}\right)= \begin{cases}1 & \text { if } \pi\left(\mathbf{x}_{t, j^{*}}\right)>\pi\left(\mathbf{x}_{t, j^{\prime}}\right), \quad \forall j^{\prime} \neq j^{*} \\ 0 & \text { otherwise. }\end{cases}
$$

By setting up a legally independent entity in the host country $j^{\prime}$, the investing firm creates a taxable nexus in that country, requiring the subsidiary company to pay an annual corporate income tax on the taxable income earned during the year. The tax burden at location $j^{\prime}$ is thus 
Figure C.1: Ratio of U.S. corporate tax losses by firm age

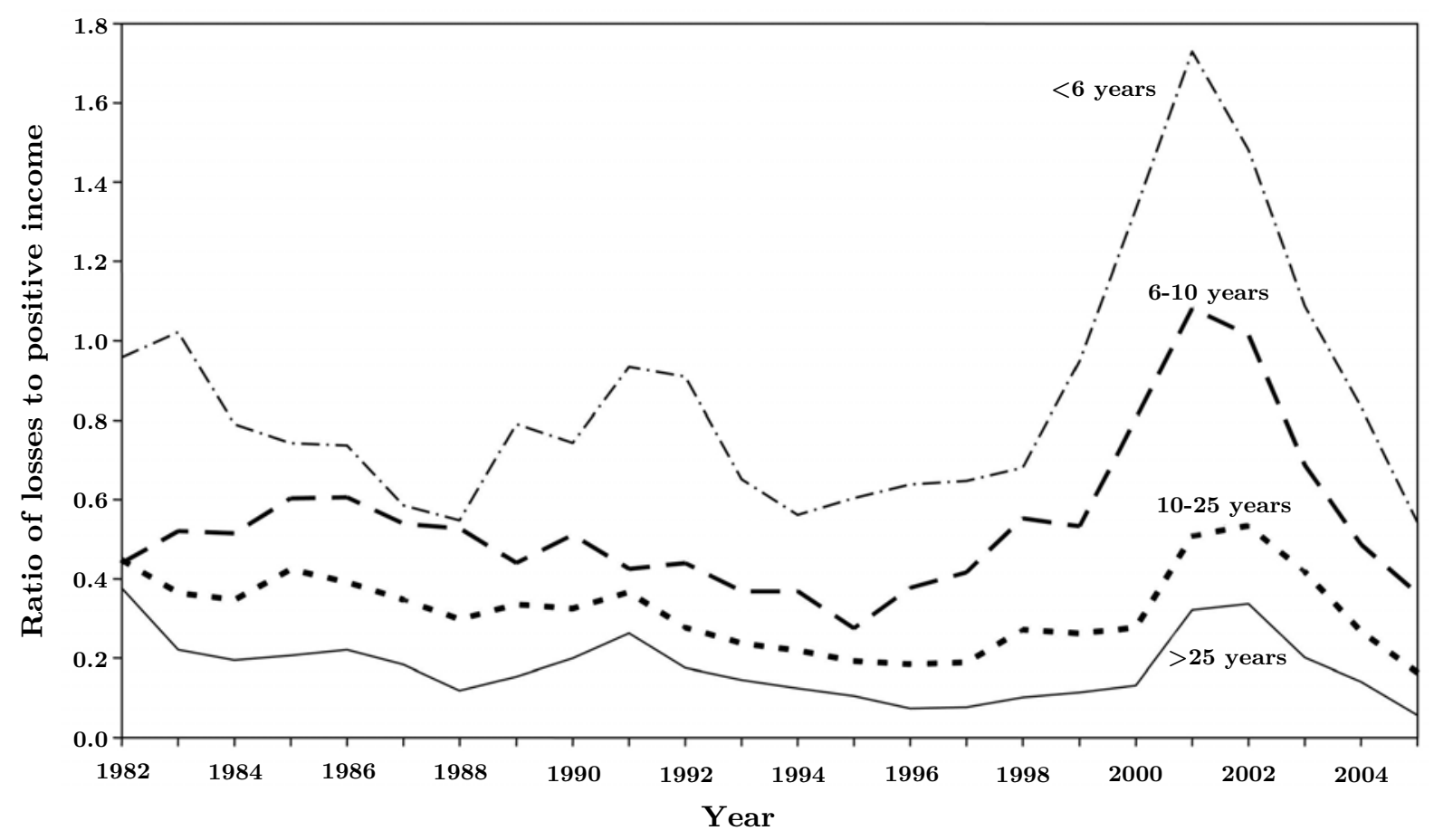

Source: Altshuler et al. (2009, p. 88). Note: The figure shows the annual ratio of the sum of losses to the sum of positive income for C corporations with U.S. local nexus between 1982 and 2005, broken down by firm age in a given year.

an important cost component among the variables in $\mathbf{x}_{j^{\prime}}$ and, all else equal, a rational investor will choose the country with the lowest tax burden. The annual tax liability of the subsidiary company is the product of the statutory corporate income tax rate and the tax base of the year. A high effective tax burden can thus be a consequence of either a high statutory tax rate or a broad tax base, the latter of which depends, inter alia, on the provisions governing inter-period loss offset. In contrast to profits which are taxable in the year they arise, net losses do not correspondingly result in an immediate tax refund by the tax authorities. Instead, a current loss can only be set off against taxable profits earned in preceding or subsequent years by way of loss carryover.

Empirical evidence shows that firms are particularly vulnerable to losses during their first years of operation. Altshuler et al. (2009) analyse the structure of U.S. corporate tax losses and find an inverse relation between firm age and the firm-specific ratio of negative to positive corporate income (see Figure C.1). This disproportionately high frequency of losses in the initial phase of business activity can be explained by the fact that the formation of a business is commonly associated with high start-up costs (e.g., for the acquisition of PPE, the engagement of external consultants or the settlement of legal fees). Since, in addition, firms are often characterised by 
a weak earnings performance during the start-up and market entry phase, restrictive provisions regarding the utilisation of losses for tax purposes should generally be associated with higher expected effective tax burdens and may, therefore, reduce the locational attractiveness of a country.

Table C.1 summarises the loss carryover rules that were in force in the EU 28 (excluding Estonia ${ }^{1}$ ) between 2002 and 2012. This overview reveals considerable heterogeneity across countries regarding the tax regulations for inter-period loss offset.

Within the period under scrutiny, only five countries provided a loss carryback relief. Under these rules, a firm may deduct a current loss from taxable profits declared in prior years, thereby receiving an immediate cash inflow from the tax authorities equal to the product of the offsettable amount and the tax rate. In this connection, the offsettable amount is the lower of the current loss in absolute terms, past taxable profits available for offset and a possibly existing statutory limit. Claiming a carryback refund requires the firm to have had a positive taxable income in past tax years. Apart from France (2002-2010) and the Netherlands (2002-2006) where firms could claim a three-year carryback, the time frame was elsewhere restricted to the tax year immediately preceding the period in which the loss arises. Furthermore, in Germany and France (since 2011) carryback was capped at $€ 511,500$ and $€ 1$ million, respectively. Before 2011, France did not provide an immediate and full refund of previously overpaid taxes. Rather, firms were initially granted a tax credit to be deducted from corporate income tax liabilities in the subsequent five years with only a remaining tax credit after the fifth year was paid directly to the firm. Finally, in Hungary a two-year loss carryback could only be applied for by companies from the agricultural sector (Spengel \& Zöllkau (2012, p. 82)).

If a carryback scheme is available, loss offset can be achieved by netting current losses against realised profits in the past. Hence, there is generally certainty about the amount and the timing of the tax refund (Barlev \& Levy $(1975$, p. 178)). The longer a loss can be carried backwards the more certain it is that it can actually be used. Carrying losses backwards has positive liquidity effects and serves as an 'insurance' against interim losses (Dreßler \& Overesch (2013, p. 514)). However, in contrast to theoretical expectations, Dreßler \& Overesch (2013) fail to empirically observe a positive influence of carryback eligibility on fixed assets investment by MNE. They discuss this finding as possibly being due to the fact that MNE are - unlike stand-alone firmscapable of avoiding materialisation of losses through transfer pricing measures or using internal

1 In Estonia, corporate profits are not taxable in the year earned but only upon distribution to the shareholders. Therefore, there are no explicit regulations governing tax loss carryover in Estonian tax law. 
Table C.1: Inter-period tax loss offset rules in the EU 28 (excluding Estonia) between 2002 and 2012

\begin{tabular}{|c|c|c|c|c|c|c|}
\hline \multirow{3}{*}{$\begin{array}{l}\text { Country } \\
\text { Austria }\end{array}$} & \multirow{2}{*}{\multicolumn{2}{|c|}{$\begin{array}{l}\text { Loss carryback } \\
\text { Maximum period (years) }\end{array}$}} & \multicolumn{4}{|c|}{ Loss carryforward } \\
\hline & & & \multicolumn{2}{|c|}{ Maximum period (years) } & \multicolumn{2}{|c|}{ Minimum taxation } \\
\hline & 2002-2012 & & 2002-2012 & $\infty$ & 2002-2012 & $\checkmark$ \\
\hline Belgium & $2002-2012$ & & $2002-2012$ & $\infty$ & $2002-2012$ & \\
\hline Bulgaria & $2002-2012$ & & $2002-2012$ & 5 & $2002-2012$ & \\
\hline Croatia & 2002-2012 & & 2002-2012 & 5 & 2002-2012 & \\
\hline Cyprus & $2002-2012$ & & $\begin{array}{l}2002 \\
2003-2011 \\
2012\end{array}$ & $\begin{array}{r}5 \\
\infty \\
5\end{array}$ & $2002-2012$ & \\
\hline Czech Republic & $2002-2012$ & & $\begin{array}{l}2002-2003 \\
2004-2012\end{array}$ & $\begin{array}{l}7 \\
5\end{array}$ & $2002-2012$ & \\
\hline Denmark & 2002-2012 & & $\begin{array}{l}2002 \\
2003-2012 \\
\end{array}$ & $\begin{array}{r}5 \\
\infty \\
\end{array}$ & $2002-2012$ & \\
\hline Finland & 2002-2012 & & 2002-2012 & 10 & 2002-2012 & \\
\hline France & $\begin{array}{l}2002-2010 \\
2011-2012 \\
\end{array}$ & $\begin{array}{l}3 \\
1 \\
\end{array}$ & $\begin{array}{l}2002-2003 \\
2004-2012 \\
\end{array}$ & $\begin{array}{r}5 \\
\infty \\
\end{array}$ & $2002-2012$ & \\
\hline Germany & $2002-2012$ & 1 & $2002-2012$ & $\infty$ & $\begin{array}{l}2002-2003 \\
2004-2012\end{array}$ & $\checkmark$ \\
\hline Greece & 2002-2012 & & 2002-2012 & 5 & 2002-2012 & \\
\hline Hungary & $2002-2012$ & $2^{a}$ & $\begin{array}{l}2002-2003 \\
2004-2012\end{array}$ & $\begin{array}{r}5 \\
\infty\end{array}$ & $2002-2012$ & \\
\hline Ireland & 2002-2012 & 1 & 2002-2012 & $\infty$ & $2002-2012$ & \\
\hline Italy & $2002-2012$ & & $\begin{array}{l}2002-2010 \\
2011-2012 \\
\end{array}$ & $\begin{array}{r}5 \\
\infty \\
\end{array}$ & $\begin{array}{r}2002-2010 \\
2011-2012 \\
\end{array}$ & $\checkmark$ \\
\hline Latvia & $2002-2012$ & & $\begin{array}{l}2002-2007 \\
2008 \\
2009 \\
2010-2011 \\
2012\end{array}$ & $\begin{array}{r}5 \\
6 \\
7 \\
8 \\
\infty\end{array}$ & $2002-2012$ & \\
\hline Lithuania & 2002-2012 & & $\begin{array}{l}2002-2008 \\
2009-2012 \\
\end{array}$ & $\begin{array}{r}5 \\
\infty \\
\end{array}$ & $2002-2012$ & \\
\hline Luxembourg & 2002-2012 & & 2002-2012 & $\infty$ & 2002-2012 & \\
\hline Malta & 2002-2012 & & 2002-2012 & $\infty$ & $2002-2012$ & \\
\hline Netherlands & $\begin{array}{l}2002-2006 \\
2007-2012 \\
\end{array}$ & $\begin{array}{l}3 \\
1 \\
\end{array}$ & $\begin{array}{l}2002-2006 \\
2007-2012 \\
\end{array}$ & $\begin{array}{r}\infty \\
9 \\
\end{array}$ & $2002-2012$ & \\
\hline Poland & 2002-2012 & & 2002-2012 & 5 & 2002-2012 & $\checkmark$ \\
\hline Portugal & 2002-2012 & & $\begin{array}{l}2002-2010 \\
2011 \\
2012\end{array}$ & $\begin{array}{l}6 \\
4 \\
5 \\
\end{array}$ & $\begin{array}{l}2002-2011 \\
2012\end{array}$ & $\checkmark$ \\
\hline Romania & $2002-2012$ & & $\begin{array}{l}2002-2008 \\
2009-2012\end{array}$ & $\begin{array}{l}5 \\
7\end{array}$ & $2002-2012$ & \\
\hline Sweden & 2002-2012 & & 2002-2012 & $\infty$ & 2002-2012 & \\
\hline Slovak Republic & $2002-2012$ & & $\begin{array}{l}2002-2009 \\
2010-2012\end{array}$ & $\begin{array}{l}5 \\
7\end{array}$ & $\begin{array}{l}2002-2004 \\
2005-2012\end{array}$ & $\checkmark$ \\
\hline Slovenia & $2002-2012$ & & $\begin{array}{l}2002-2005 \\
2006 \\
2007-2012\end{array}$ & $\begin{array}{r}5 \\
7 \\
\infty\end{array}$ & $2002-2012$ & \\
\hline Spain & $2002-2012$ & & $\begin{array}{l}2002-2011 \\
2012\end{array}$ & $\begin{array}{l}15 \\
18\end{array}$ & $\begin{array}{l}2002-2010 \\
2011-2012\end{array}$ & $\checkmark$ \\
\hline United Kingdom & 2002-2012 & 1 & 2002-2012 & $\infty$ & 2002-2012 & \\
\hline
\end{tabular}

Notes: ${ }^{a}$ Restricted to companies from the agriculture sector. Source: IBFD European Tax Handbooks 2002-2012. 
capital markets so that fiscal support measures are of subordinate importance in this respect (Dreßler \& Overesch (2013, p. 528)). But even if the availability of a loss carryback regime may not exert influence on the eventual level of corporate investment, in the location decision its very existence may still signal a country's particular readiness to participate in potential losses that investors may encounter. Therefore, I state:

Hypothesis 1 (H1) On average, the existence of a loss carryback scheme increases the location choice probability of MNEs.

Hypothesis 2 (H2) On average, the positive association between the location choice probability of MNEs and the existence of a loss carryback scheme increases with the length of the carryback period.

In addition to the foregoing, the relevance of a carryback provision should be moderated by the expected degree of loss exposure. The more vulnerable a firm is to losses from its business operations, the more weight should be given to the scope of loss utilisation for tax purposes. As a carryback regime widens this scope (Barlev \& Levy (1975, p. 177)), I hypothesise:

Hypothesis 3 (H3) The positive effect of a carryback scheme on the location choice probability of MNEs becomes stronger the more significant the exposure to loss is.

Between 2002 and 2012, a loss carryforward was available in all countries. However, none of them allowed interest on loss carryforwards. This implies that the economic value of a loss declines the more the longer loss offset is postponed to the future. Moreover, $19 \mathrm{EU}$ Member States imposed a time limitation on loss carryforwards in at least one year during the observation period. The lengths of the carryforward periods varied significantly across countries. Relatively generous time spans of ten years or more in Finland and Spain were contrasted with notably stricter time limits of five years or less especially in Eastern Europe.

In general, time limitations expose tax losses to the risk of an irrevocable forfeiture because any unused portion of a tax loss may not be used beyond the carryforward period. Therefore, I pose as hypothesis:

Hypothesis 4 (H4) On average, time limitations on loss carryforwards decrease the location choice probability of MNEs. 
Given that the time-span for using a tax loss incurred in a given year is finally determined by the legal provisions valid in that year, the investor knows with certainty by when at the latest a possibly expected (start-up) loss must be offset in order to prevent its forfeiture. The narrower the time window dictated by tax law the sooner firms need to become profitable to achieve a full loss relief. Following Dreßler \& Overesch (2013), I do therefore expect time limitations of five years or less to affect the locational attractiveness of a country more severely than longerterm time limitations of more than five years. From this consideration it follows the following hypothesis:

Hypothesis 5 (H5) On average, short-term time limitations on loss carryforwards of five years or less decrease the location choice probability of MNEs more strongly than longer-term time limitations of more than five years.

In analogy to the reasoning above, any negative investment impact of time limitations on loss carryforwards should be the more pronounced the more exposed to losses the planned investment is considered to be:

Hypothesis 6 (H6) The negative effect of carryforward time limitations on the location choice probability of MNEs becomes stronger the more significant the exposure to loss is.

Seven countries employed minimum taxation rules. Such restrictions put a ceiling on the amount of carryforward losses that may be charged against positive taxable income of the current year. Consequently, a tax liability may arise even though a firm's stock of losses accumulated over previous tax years exceeds the firm's current profits. In practice, two basic forms of minimum taxation rules can be identified. The most common approach is to specify the maximum amount of loss compensation in a given year as a share of current profits. This method was used in Austria, Italy (2011-2012), Portugal (2012) and, in essence, also in Spain (2011-2012) with the difference that the Spanish provisions were only targeted towards companies with an annual turnover above a statutory threshold. Another modification was implemented in Germany (2004-2012) and France (2012) where a limitation on the deductibility of losses did only apply to company-years with a taxable income before loss-offset over $€ 1$ million. In contrast to the aforementioned countries, Poland and Slovak Republic made direct reference to the stock of carryforward losses in order to determine the maximum permissible offset amount. In Poland, the annual deduction limit was set at $50 \%$ of the amount of loss carryforwards existing at the 
end of the prior fiscal year. In the Slovak Republic (2002-2004), carryforward losses had to be split up into five equal portions and could thus only be used up on a pro-rata basis.

The negative financial effects already arising from lacking interest on carryforward may become further compounded when minimum taxation rules apply. Any portion of loss carryforwards exceeding the offsettable amount as determined by the minimum taxation rule cannot be deducted from current profits and must be carried forward even longer. This likely results in earlier tax payments and increases the risk to encounter liquidity problems. From this, I derive the hypothesis:

Hypothesis $\mathbf{7}(\mathbf{H 7})$ On average, the existence of a minimum taxation provision decreases the location choice probability of MNEs.

Again, the relevance of this type of loss offset limitation to the investor should depend on the anticipated degree of loss exposure. Correspondingly, I hypothesise:

Hypothesis 8 (H8) The negative effect of a minimum taxation provision on the location choice probability of MNEs becomes stronger the more significant the exposure to loss is.

\section{Empirical methodology}

With regard to any individual location, the investing firm has to make a binary choice between establishing a subsidiary company there or not. The standard econometric approach to modeling discrete choice problems of this sort is the conditional logit model proposed by McFadden (1974). As formalised by Equation C.1, the investing firm will choose to locate its subsidiary in the country that offers the highest expected profit. Among the vector of location-specific parameters $\left(\mathbf{x}_{j}\right)^{2}$ from Equation C.1 which are supposed to determine profit expectations at location $j$, only a subset of parameters is observable (hereafter summarised as vector $\mathbf{X}_{j}$ ) while there is another subset of non-observable parameters (in the following denoted by $\boldsymbol{\epsilon}_{j}$ ). With this extension, the expected profit at location $j$ can be expressed as

$$
\pi_{j}=\boldsymbol{\beta} \cdot \mathbf{X}_{j}+\boldsymbol{\epsilon}_{j}
$$

where $\boldsymbol{\beta}$ is a vector of parameter coefficients to be estimated. According to McFadden (1974, p. 108), the probability that location $j^{*}$ rather than $j^{\prime} \neq j^{*}$ is chosen by a randomly drawn

2 The time subscript $t$ is omitted for simplicity. 
investor is then given by

$$
\begin{aligned}
\operatorname{Pr}\left[y=j^{*} \mid \mathbf{X}_{j^{*}}\right] \equiv P_{j^{*}} & =\operatorname{Pr}\left[\pi\left(\mathbf{x}_{j^{*}}\right)>\pi\left(\mathbf{x}_{j^{\prime}}\right)\right], \quad \forall j^{\prime} \neq j^{*} \\
& =\operatorname{Pr}\left[\boldsymbol{\beta} \cdot \mathbf{X}_{j^{*}}+\boldsymbol{\epsilon}_{j^{*}}>\boldsymbol{\beta} \cdot \mathbf{X}_{j^{\prime}}+\boldsymbol{\epsilon}_{j^{\prime}}\right], \quad \forall j^{\prime} \neq j^{*} \\
& =\operatorname{Pr}\left[\boldsymbol{\beta} \cdot \mathbf{X}_{j^{*}}-\boldsymbol{\beta} \cdot \mathbf{X}_{j^{\prime}}>\boldsymbol{\epsilon}_{j^{\prime}}-\boldsymbol{\epsilon}_{j^{*}}\right], \quad \forall j^{\prime} \neq j^{*} .
\end{aligned}
$$

Under the assumption that the random error terms $\epsilon$ are independently extreme value type 1 distributed $^{3}$, McFadden (1974, pp. 111-114) shows that the location choice probability $P_{j^{*}}$ takes the standard logit form

$$
P_{j^{*}}=\frac{\exp \left(\boldsymbol{\beta} \cdot \mathbf{X}_{j^{*}}\right)}{\sum_{j=1}^{J} \exp \left(\boldsymbol{\beta} \cdot \mathbf{X}_{j}\right)},
$$

from which it follows that the beta coefficients of $\mathbf{X}_{j^{*}}$ can be derived through maximum likelihood estimation.

\section{Data and variables}

\subsection{Sample selection}

From the Amadeus database release 263 (update number 2630 as of 5 August 2016), I compile micro data on firm establishments between 2002 and 2012 in the European Union $28 .^{4}$ The gathered information comprises firms' unique identification numbers, their dates of incorporation $^{5}$, their industry sector affiliations according to the NACE Rev. 2 classification system as well as their global ultimate owners' identification numbers. The firms' countries of residence are indicated by the two-digit letter ISO code heading each identification number. Table C.2 summarises the sample selection procedure:

In the first two steps I extract all data from the database that refer to firm establishments within the European Union 28 between 2002 and 2012. In the third step, I restrict my sample to investments made by industrial companies, thereby ruling out investments made by companies

3 From this follows the independence of irrelevant alternatives (IIA) assumption according to which an investor's preferences for location A or location B do not depend on the attributes of a third location C. If the IIA assumption does not hold, the conditional logit model is not appropriate. Long \& Freese (2006, p. 243) argue that the IIA assumption would not cause problems in applications "where the alternatives "can plausibly be assumed to be distinct and weighted independently in the eyes of each decision maker' ". This should be the case here because the individual EU Member States can be assumed to be sufficiently dissimilar in important aspects (e.g., in terms of their market sizes, legal systems, language communities).

4 Amadeus is a commercial comprehensive pan-European database provided by Bureau van Dijk with financial information on approximately 22 million public and private companies in 44 European countries.

5 In line with Barrios et al. (2012, p. 951), I presume that a company's year of incorporation as stated in Amadeus corresponds to the company's year of establishment. 
Table C.2: Sample selection

\begin{tabular}{lrr}
\hline Selection criterion & Observations \\
\hline 1. Firms incorporated between 2002 and 2012 & $11,705,699$ \\
2. Firms resident in the EU-28 & $8,743,316$ \\
3. Firms indirectly or directly majority-owned by an EU-28 resident global ultimate owner & $-8,420,672$ & 322,644 \\
classified as industrial company & $-8,861$ & 313,783 \\
4. Firms being public or private limited companies & $-1,155$ & 312,628 \\
5. Firms with valid identification number & $-251,232$ & 61,396 \\
6. Foreign residency of global ultimate owner & $-1,460$ & 59,936 \\
7. Firms with non-missing NACE Rev. 2 industry sector classification & $-15,128$ & 44,808 \\
8. Global ultimate owners without multiple FDI in the same industry of a country in a year & -871 & 43,937 \\
9. Firms and global ultimate owners resident outside Estonia & $-12,914$ & 31,023 \\
10. Firms not operating in NACE Rev. 2 industry sectors K, L, N, O, P, Q, R, S, T or U & $\mathbf{3 1 , 0 2 3}$ \\
\hline Final sample & -123 \\
\hline
\end{tabular}

Note: The table shows the selection procedure applied to the AmADEus data.

from the financial sector, private equity or venture capital firms, investment funds, foundations, non-corporate shareholders and public, state or government institutions. Lacking ownership information on an annual basis, I must make the assumption that the global ultimate owner at the time of establishment of the subsidiary is equivalent to the owner reported in the data as of August 2016. The fourth step is to ensure that I retain in the sample only firms that are corporate entities which are independently liable to corporation tax in their countries of residence. Firms that are not assigned an individual identifier are deleted in the fifth step. As I am interested in the tax effects on foreign direct investments, I keep in the sixth step only those observations where the subsidiary company is located in another country than its global ultimate owner. For reasons outlined below, I need information about the subsidiaries' industry affiliations. Records with missing information about the NACE Rev. 2 industry sector are, therefore, deleted in the seventh step. Owing to the inability of the conditional logit model to take into account multiple positive outcomes per combination of investor, year, industry and country, I eliminate any such duplicates in the eigth step. As already mentioned in Section 2.2, the Estonian tax system differs structurally from the tax systems of the other countries under scrutiny. Therefore, I discard in the ninth step all Estonia-related observations. Finally, I drop from the sample all firm establishments in industry sectors where special tax provisions are likely to apply. In detail, I remove all observations related to NACE industry sectors K, L and N to U. ${ }^{6}$ This sample selection leaves me with a total of 31,023 observations on new subsidiary

6 K: Financial and insurance activities; L: Real estate activities; N: Administrative and support service activities; O: Public administration and defence, compulsory social security; P: Education; Q: Human health and social work activities; R: Arts, entertainment and recreation; S: Other service activities; T: Activities of households as employers; undifferentiated goods- and services-producing activities of households for own use; U: Activities 
Table C.3: Breakdown of subsidiary establishments in baseline sample by home and host countries

\begin{tabular}{|c|c|c|c|}
\hline \multirow[t]{2}{*}{ Country } & \multirow[t]{2}{*}{ Number of parent companies by home country } & \multicolumn{2}{|c|}{ Number of subsidiary establishments } \\
\hline & & By home country & By host country \\
\hline Austria & 799 & 1,202 & 854 \\
\hline Belgium & 1,022 & 1,411 & 699 \\
\hline Bulgaria & 114 & 127 & 354 \\
\hline Croatia & 52 & 59 & 625 \\
\hline Cyprus & 1,910 & 2,445 & 66 \\
\hline Czech Republic & 657 & 769 & 1,817 \\
\hline Denmark & 820 & 1,238 & 778 \\
\hline Finland & 283 & 462 & 333 \\
\hline France & 1,461 & 2,143 & 1,681 \\
\hline Germany & 2,922 & 4,247 & 4,725 \\
\hline Greece & 181 & 217 & 156 \\
\hline Hungary & 592 & 652 & 178 \\
\hline Ireland & 339 & 577 & 123 \\
\hline Italy & 1,690 & 2,096 & 2,107 \\
\hline Latvia & 36 & 44 & 625 \\
\hline Lithuania & 175 & 199 & 226 \\
\hline Luxembourg & 1,879 & 2,918 & 190 \\
\hline Malta & 249 & 329 & 23 \\
\hline Netherlands & 1,793 & 2,540 & 1,262 \\
\hline Poland & 376 & 455 & 3,020 \\
\hline Portugal & 272 & 347 & 845 \\
\hline Romania & 39 & 40 & 3,665 \\
\hline Spain & 1,117 & 1,514 & 1,459 \\
\hline Sweden & 959 & 1,446 & 991 \\
\hline Slovak Republic & 309 & 381 & 1,598 \\
\hline Slovenia & 218 & 243 & 148 \\
\hline United Kingdom & 2,006 & 2,922 & 2,475 \\
\hline Total & 22,270 & 31,023 & 31,023 \\
\hline
\end{tabular}

Note: The table provides an overview over the geographical distribution of subsidiary establishments included in the baseline sample.

establishments.

As displayed in Table C.3, the final sample includes a total of 22,270 parent companies. Hence, the average parent firm has set up 1.4 foreign subsidiaries in the period under review. The second column reveals that parent companies from Germany, the United Kingdom and Luxembourg account for 32.5 percent of all investments in the sample. By comparison, only few FDI stem from Romania, Latvia and Croatia. The third column of the table shows that Germany, Romania and Poland are most frequently chosen as investment locations. These countries host almost 36.8 percent of all newly established companies. In this regard, Malta, Cyprus and Ireland are of only marginal significance as theses countries attracted no more than 0.7 percent of all investments in the sample.

Table C.4 provides a breakdown by the subsidiaries' industry sector affiliations. Between 
Table C.4: Breakdown of subsidiary establishments in baseline sample by NACE Rev. 2 industry sector

\begin{tabular}{lr}
\hline NACE Rev. 2 industry sector & Number of subsidiary establishments \\
\hline A: Agriculture, forestry and fishing & 645 \\
B: Mining and quarrying & 225 \\
C: Manufacturing & 4,916 \\
D: Electricity, gas, steam and air conditioning supply & 1,081 \\
E: Water supply; sewerage, waste management and remediation activities & 247 \\
F: Construction & 2,747 \\
G: Wholesale and retail trade; repair of motor vehicles and motorcycles & 9,433 \\
H: Transportation and storage & 1,598 \\
I: Accommodation and food service activities & 831 \\
J: Information and communication & 3,007 \\
M: Professional, scientific and technical activities & 6,293 \\
\hline Total & $\mathbf{3 1 , 0 2 3}$ \\
\hline
\end{tabular}

Note: The table provides an overview over the industry sector distribution of subsidiary establishments included in the baseline sample.

Figure C.2: Distribution of subsidiary establishments in baseline sample over time

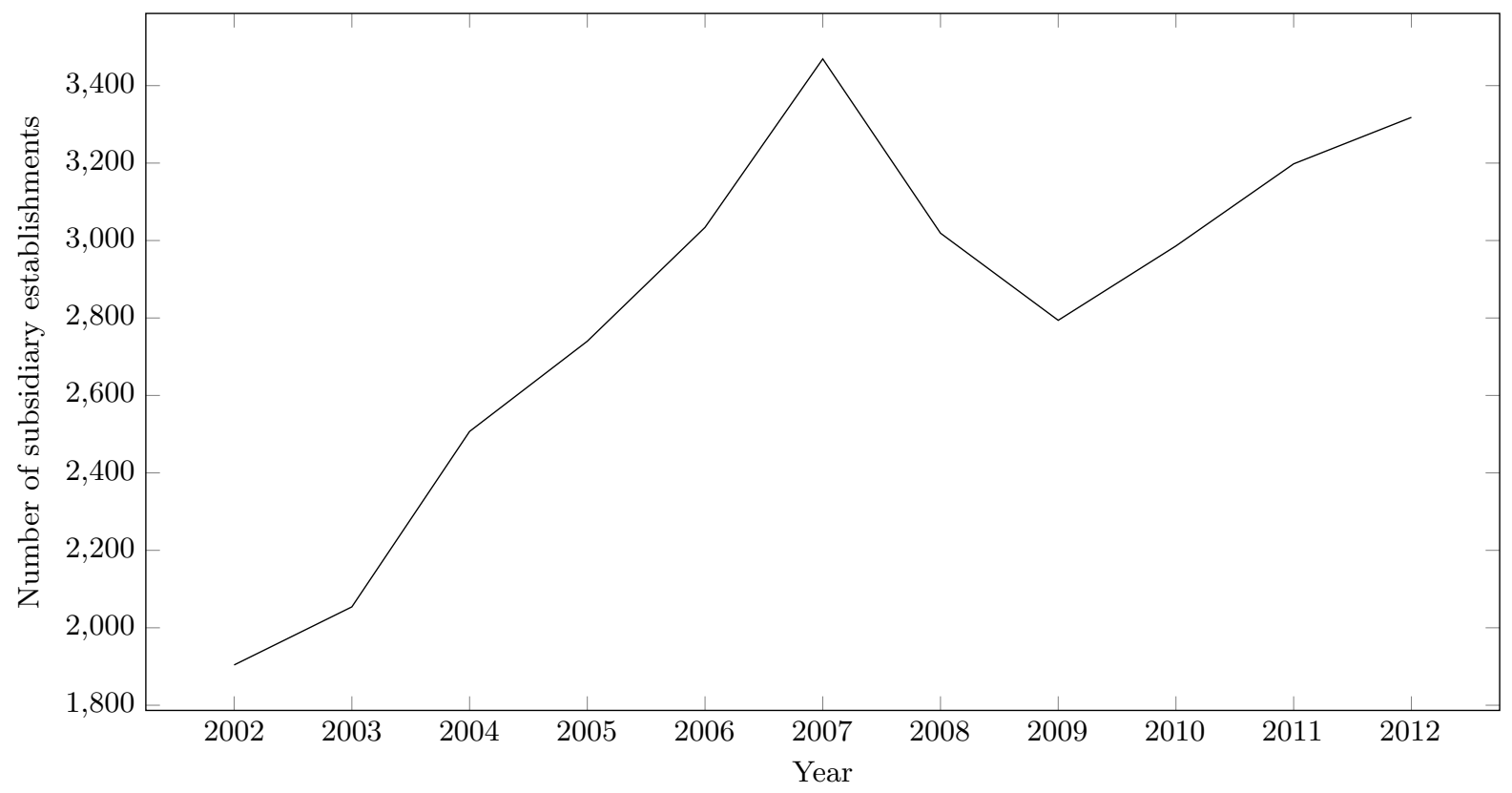

Source: Own figure.

2002 and 2012, the largest share of FDI in the sample was directed towards the wholesale and retail trade sector (30.4 percent). Ranks two and three are held by the professional, scientific and technical activities industry (20.3 percent) and the manufacturing industry (15.8 percent), respectively. In temporal terms, MNE activity has grown consistently between 2002 and 2007. Apparently as a consequence of the financial crisis, the number of FDI projects decreased in the two following years before it started to rise again from 2010 onwards and roughly reached the pre-crisis level in 2012. 


\subsection{Proxy variables for tax burden and loss exposure}

The determinants of a firm's expected tax burden in a country are the statutory corporation tax rate (STR) and the width of the tax base. Devereux \& Griffith (1999) propose a measure for an effective average tax rate (EATR) which condenses the statutory tax rate and a broad range of applicable tax base components into a single measure of tax burden on profitable investments. ${ }^{7}$ Based on neo-classical investment theory, the EATR captures both the direct effect of taxation on after-tax profitability and its indirect impact on the cost of capital (Buettner \& Wamser $(2009$, p. 303)). Yet, a core limitation of the EATR for the purpose of this study is that it is, by construction, unable to cover the effects of tax loss offset provisions.

My approach to analyse the location incentives of loss offset regimes is inspired by the identification strategy of Dreßler \& Overesch (2013) who model loss carryover rules in the regression through dummy variables. To test the association between location choice probability and the availability of carryback, I consider the dummy variable LCB in the conditional logit regression that takes on the value 1 for countries with carryback regimes and 0 otherwise. In order to verify my conjecture that differences with respect to the length of the carryback period are reflected in location choice probabilities, I further dichotomise carryback availability into shortterm $(\mathrm{LCB}=1$ year $)$ and long-term $(\mathrm{LCB}>1$ year) carryback periods of one and more than one year, respectively. The existence of carryforward time restrictions is captured by the dummy variable LCF LTD. Dichotomising the group of countries with time-limited carryforward into subgroups of locations with short-term time limitations (LCF $\leq 5$ years) and long-term time limitations ( $\mathrm{LCF}>5$ years) allows me to test for the sensitivity of location choice probabilities to different degrees of strictness in this regard. The existence of a minimum taxation provision in a country is indicated by the dummy variable MINTAX.

As previously stated, the anticipated degree of loss exposure should moderate the influence of loss offset constraints on the location choice. Directly observing how seriously an individual investor expects to be affected by losses and their discriminatory tax treatment is not possible though. As pointed out by Barlev \& Levy (1975) and Dreßler \& Overesch (2013), the impact of loss offset restrictions on an investor's anticipated effective tax burden basically depends on three factors: the general risk of loss occurrence, the time pattern of future earnings and the relative size of expected losses and profits. Depending on how these determinants interact with

7 The most important tax base elements considered are capital allowances for fixed assets, tax credits and non-profit taxes. A detailed description of the methodology is provided by Devereux, Elschner, et al. (2008). 
each other, the tax burden influence of losses may be rather strong or weak. Given that future tax payments under asymmetric taxation of profits and losses are strongly path-dependent (i.e. the size of the tax base in a certain year is a function of prior years' tax bases), there is reason to assume that investors do not carry out sophisticated planning of future taxable income figures at the individual firm level but do rather process information about the development of comparable firms operating in a specific country-industry cluster for decision-making purposes.

According to this reasoning, Dreßler \& Overesch (2013, pp. 516 sq.) capture the general risk of loss occurrence by means of a proxy variable LRI which represents the annual percentage of firms from a certain industry sector reporting a loss in their financial statements. My definition of LRI is basically identical, but I do not compute yearly means. For some triplets of country, industry sector and year, Amadeus exhibits low coverage of profit and loss statement data. In these cases, averaging on an annual basis would produce artificial jumps in the data over time which are likely to bias my results. Therefore, I modify the Dreßler \& Overesch (2013) computation by taking country/industry-specific averages over the entire observation period 2002 to 2012 . Table C.5 displays that, on average, one out of four firms $(26.1 \%)$ reported a pre-tax loss in their financial statements. The statistics reveal further that for some country/industry pairs in the sample no loss firms are observed, while the maximum share of loss firms is 0.616.

While the LRI variable is my preferred measure for loss exposure, I will also address the issue how the temporal structure of profits and losses factors into the limited loss offset-location choice relation for the purpose of robustness checks. If a subsidiary is established in a country providing for a limited carryforward period, it is essential for the firm to become profitable as closely as possible in order to use up potential start-up losses. In addition, the uncertainty whether a carryback scheme existing at the time of the decision making will still be available when the firm has overcome an initial loss phase increases with the duration of the latter. The probability of successfully recovering any losses incurred should thus be negatively related to the number of consecutive start-up loss years. Provided that market conditions for new entrants in a given country/industry cell are sufficiently homogeneous over time, the average number of years over which firms from the same peer group continuously incur losses may represent relevant information to investors. To construct my proxy variable for the mean duration of start-up loss periods (DSL), I count the number of consecutive loss years for each firm with available AmAdeus data on pre-tax book income over the first five years of operation and average the resultant figures across country/industry cells. As shown in Table C.5, it takes 0.7 years for a 
newly established firm to realise a positive pre-tax book income for the first time on average. None of the country/industry pairs is characterised by an average start-up loss period of more than four years.

\subsection{Control variables}

Besides the tax burden-related covariates, I include several control variables in my regressions. GDP BILAT serves as a proxy for the size of a host country's market. It is defined as the share of a host country's GDP in the total of GDPs of all potential host countries in the sample (Barrios et al. (2012)). Especially for market-seeking FDI, market size is a key determinant of location choice and should have a positive impact on the location probability of MNE. To address location advantages that efficiency-seeking FDI are taking into consideration, I include three variables that control for physical and cultural distance between a potential host country and the investor's country of residence. The simple distance in kilometres (DIST) between the most populated cities in the home and the host country approximates transportation and communication costs. I expect a negative impact on the location choice probability. The dummy variable COMBORD indicates whether both countries share a common border. This is to account for situations where DIST likely overstates distance considerations because investors actually plan to locate their foreign subsidiary immediately adjacent to the border. The coefficient on the common border dummy should be estimated with positive sign. The dummy variable COMLEG reflects cultural distance in terms of differences in the legal system. My expectation is that, ceteris paribus, MNE prefer to invest in countries that have similar legal rules as the home country because this may facilitate cross-border business operations (Barrios et al. (2009)). Spatial concentration of firms in the same industry sector is likely to generate positive externalities (Buch et al. (2005), Swenson (2000)). Therefore, I include a proxy for host country-industry sector-specific agglomeration economies (AGGLO). I measure the degree of agglomeration by the percentage share of employment in the respective industry sector and expect a positive sign on that coefficient. The variables WAGES and LR control for the cost of the production factors labour and capital which are expected to have a negative impact on the location probability of MNE. To control for the stability of the political and business environment in a potential host country, I include the PRS political risk index (RISK) in my regressions. The index attributes larger values to less risky countries which is why its coefficient should be estimated with positive 
Table C.5: Descriptive statistics and variables measurement

\begin{tabular}{lrrrrr}
\hline Variable & Obs & Mean & Std. Dev. & Min & Max \\
\hline FDI & 766,963 & 0.040 & 0.196 & 0 & 1 \\
STR & 766,963 & 0.244 & 0.075 & 0.100 & 0.402 \\
EATR & 766,963 & 0.225 & 0.071 & 0.088 & 0.370 \\
LCB & 766,963 & 0.185 & 0.388 & 0 & 1 \\
LCB = 1 year & 766,963 & 0.141 & 0.348 & 0 & 1 \\
LCB > 1 year & 766,963 & 0.045 & 0.207 & 0 & 1 \\
LCF LTD & 766,963 & 0.524 & 0.499 & 0 & 1 \\
LCF $\leq 5$ years & 766,963 & 0.340 & 0.474 & 0 & 1 \\
LCF > 5 years & 766,963 & 0.184 & 0.387 & 0 & 1 \\
MINTAX & 766,963 & 0.134 & 0.340 & 0 & 1 \\
LRI & 766,963 & 0.261 & 0.082 & 0.000 & 0.616 \\
DSL & 756,520 & 0.709 & 0.325 & 0.000 & 4.000 \\
GDP BILAT & 766,963 & 0.040 & 0.060 & 0.000 & 0.251 \\
DIST & 766,963 & $1,346.240$ & 727.028 & 59.617 & $3,766.310$ \\
CONTIG & 766,963 & 0.125 & 0.330 & 0 & 1 \\
COMLEG & 766,963 & 0.201 & 0.400 & 0 & 1 \\
AGGLO & 766,963 & 0.151 & 0.092 & 0.007 & 0.369 \\
WAGES & 766,963 & $2,527.200$ & $1,614.530$ & 164.900 & $6,480.100$ \\
LR & 766,963 & 0.071 & 0.035 & 0.005 & 0.354 \\
RISK & 766,963 & 0.801 & 0.102 & 0.551 & 0.987 \\
JOINTEU & 766,963 & 0.887 & 0.316 & 0 & 1 \\
\hline Notes: The & & & 0 \\
\hline
\end{tabular}

Notes: The table shows descriptive statistics on the dependent and independent variables included in the baseline regression. FDI is a binary variable equaling 1 in case a subsidiray is located in a host country and 0 if not (Source: Own calculations based on AmAudeus data). STR is the statutory corporation tax rate in a host country (Source: Spengel, Endres, et al. (2014)). EATR is the effective average tax rate in a host country following the Devereux \& Griffith (1999) methodology (Source: Spengel, Endres, et al. (2014)). LCB is a binary variable equaling 1 if a host country provides for loss carryback relief and 0 otherwise. LCB $=\mathbf{1}$ year is a binary variable equaling 1 if a host country provides for a one-year carryback period and 0 otherwise. LCB $>\mathbf{1}$ year is a binary variable equaling 1 if a host country provides for a carryback period of more than one year and 0 otherwise. LCF LTD is a binary variable equaling 1 if a host country applies a time limitation on loss carryforwards and 0 otherwise. $\mathbf{L C F} \leq \mathbf{5}$ years is a binary variable equaling 1 if a host country applies a short-term time limitation on loss carryforwards of five years or less and 0 otherwise. LCF $>\mathbf{5}$ years is a binary variable equaling 1 if a host country applies a longer-term time limitation on loss carryforwards of more than five years and 0 otherwise. MINTAX is a binary variable equaling 1 if a host country applies a minimum taxation provision on carryforward losses and 0 otherwise. The information on inter-period tax loss offset rules are derived from IBFD European Tax Handbooks 2002-2012. LRI denotes the average (over the observation period) of the host country-industry specific annual share of companies reporting a negative pre-tax book income in the total population of companies from the same country and industry for which a pre-tax book income is reported in Amadeus (Source: Own calculations based on Amaudeus data). DSL is the host countryindustry specific average start-up loss period length (in years), i.e. it indicates after how many years with consecutive negative pre-tax book incomes a company reports a positive pre-tax book income for the first time on average (Source: Own calculations based on Amaudeus data). DIST is the distance in kilometres between the two most populated cities of home and host country (Source: CEPII (http://www.cepii.fr/CEPII/en/bdd_modele/presentation.asp?id=8)). CONTIG is a binary variable equaling 1 if home and host country share a common border and 0 otherwise (Source: CEPII (http: //www.cepii.fr/CEPII/en/bdd_modele/presentation.asp?id=8)). COMLEG is a binary variable equaling 1 if home and host country share a common origin of law and 0 otherwise. It distinguishes four origins of law: English, French, German and Nordic (Source: La Porta, Lopez de Silanes \& Shleifer (2008)). GDP BILAT is the ratio of the GDP in a host country to the sum of GDP of all host countries (GDP at constant 2005 prices in US Dollars; Source: UN National Accounts Main Aggregates Database). AGGLO denotes host country-year-specific employment in an industry sector in percent of total employment (Source: Eurostat). WAGES are gross average monthly wages in US\$ at current exchange rates in a host country in a year (Source: UNECE Statistical database). LR is the bank interest rate for private sector loans in a host country in a year (Source: WorldBank WDI database, augmented with data from OECD.stats, Danmarks Statistik, Lietuvos bankas, Bank Centrali ta' Malta, De Nederlandsche Bank and Sveriges Riksbank). RISK is the Political Risk Services country risk index for a host country in a year (Source: PRS Group). JOINTEU is a binary variable equaling 1 if home and host country are jointly Member States of the European Union in a year and 0 otherwise. 
sign. Finally, joint EU membership of two countries should facilitate bilateral business activities between these countries. To capture such effects, I include the dummy variable JOINTEU in the regression which is 1 in case both the home and the host country are EU member states in the year of subsidiary establishment and 0 otherwise. Table C.5 provides detailed information about the variables' measurement and summary statistics of the data.

\section{Results}

\subsection{Baseline analysis}

Table C.6 reports conditional logit estimates of the probability of new subsidiary location for the full panel of observations ${ }^{8}$ obtained from the following regression equation:

$$
\begin{aligned}
\operatorname{logit}\left(P_{j^{*}}\right)=\log \left(\frac{P_{j^{*}}}{1-P_{j^{*}}}\right)= & \beta_{1} \times S T R_{j t}+\beta_{2} \times T L O_{j k t}+\beta_{3} \times L R I_{j k}\left[+\beta_{4} \times T L O_{j k t} \times L R I_{j k}\right] \\
& +\boldsymbol{\mu} \times \mathbf{W}_{i j}+\boldsymbol{\phi} \times \mathbf{X}_{i j t}+\boldsymbol{\lambda} \times \mathbf{Y}_{j t}+\boldsymbol{\psi} \times \mathbf{Z}_{j k t}+\gamma_{j}+\delta_{k}+\eta_{t}
\end{aligned}
$$

where $T L O$ stands for the specific tax loss offset variable which is studied in a given context and the vectors $\mathbf{W}, \mathbf{X}, \mathbf{Y}, \mathbf{Z}$ contain the control variables mentioned above. The term $\beta_{4} \times T L O_{j k t} \times$ $L R I_{j k}$ is put in brackets because interactions between loss exposure and loss offset restrictions are only considered in my preferred model specifications 3, 6 and 8. In order to control for unobserved effects that might have an equal influence on all investment decisions concerning a specific host country or industry sector (irrespective of time) or investment decisions in a specific year (irrespective of host country or industry), all model specifications contain the fixed effects variables $\gamma_{j}, \delta_{k}$ and $\eta_{t}$, respectively.

To ease the interpretation of the results, the coefficient estimates of the tax variables are converted to average marginal effects (AME) which are reported at the bottom of the table. Throughout all specifications, the AME of the location choice probability with respect to the statutory tax rate is estimated to be -0.6 , indicating that a 1 percent increase in the STR is associated with a 0.6 percent decline in the probability of a country to be chosen as investment location. Almost identical effect sizes are identified by Barrios et al. (2012, p. 956) and Hebous, Ruf \& Weichenrieder (2011, p. 834).

Surprisingly, my results connote a statistically significant positive association between location

8 Due to missing LRI data for some country-industry cells not the total amount of 31,023 location decisions $\times$ 26 countries $=805,598$ observations but only 766,963 observations effectively enter the baseline regression. 
Table C.6: Location probability and tax loss offset provisions-baseline regression

\begin{tabular}{|c|c|c|c|c|c|c|c|c|}
\hline & $\begin{array}{l}(1) \\
\mathrm{LCB}\end{array}$ & $\begin{array}{c}(2) \\
\mathrm{LCB}(\text { split})\end{array}$ & $\begin{array}{c}(3) \\
\text { LCB (split) } \\
\times \text { LRI }\end{array}$ & $\begin{array}{c}(4) \\
\text { LCF LTD }\end{array}$ & $\begin{array}{l}(5) \\
\text { LCF LTD } \\
\text { (split) }\end{array}$ & $\begin{array}{c}(6) \\
\text { LCF LTD } \\
\text { (split) } \times \text { LRI }\end{array}$ & $\begin{array}{l}(7) \\
\text { MINTAX }\end{array}$ & $\begin{array}{c}(8) \\
\text { MINTAX } \times \\
\text { LRI }\end{array}$ \\
\hline STR & $\begin{array}{l}-3.600^{* * *} \\
{[-4.22]}\end{array}$ & $\begin{array}{l}-3.620^{* * *} \\
{[-4.11]}\end{array}$ & $\begin{array}{l}-3.627^{* * *} \\
{[-4.16]}\end{array}$ & $\begin{array}{l}-3.644^{* * *} \\
{[-3.65]}\end{array}$ & $\begin{array}{l}-3.477^{* * *} \\
{[-3.39]}\end{array}$ & $\begin{array}{l}-3.484^{* * *} \\
{[-3.48]}\end{array}$ & $\begin{array}{l}-3.526^{* * *} \\
{[-4.38]}\end{array}$ & $\begin{array}{l}-3.531^{* * *} \\
{[-4.40]}\end{array}$ \\
\hline LCB & $\begin{array}{l}0.376^{* * *} \\
{[2.75]}\end{array}$ & & & & & & & \\
\hline $\mathrm{LCB}=1$ year & & $\begin{array}{l}0.335^{*} \\
{[1.81]}\end{array}$ & $\begin{array}{l}0.538^{*} \\
{[1.84]}\end{array}$ & & & & & \\
\hline $\mathrm{LCB}>1$ year & & $\begin{array}{l}0.376^{* * *} \\
{[2.75]}\end{array}$ & $\begin{array}{l}0.869^{* * *} \\
{[3.55]}\end{array}$ & & & & & \\
\hline $\mathrm{LCB}=1$ year $\times \mathrm{LRI}$ & & & $\begin{array}{l}-0.433 \\
{[-0.41]}\end{array}$ & & & & & \\
\hline $\mathrm{LCB}>1$ year $\times$ LRI & & & $\begin{array}{l}-1.835^{* *} \\
{[-2.45]}\end{array}$ & & & & & \\
\hline LCF LTD & & & & $\begin{array}{l}-0.023 \\
{[-0.18]}\end{array}$ & & & & \\
\hline $\mathrm{LCF} \leq 5$ years & & & & & $\begin{array}{c}0.015 \\
{[0.10]}\end{array}$ & $\begin{array}{c}0.026 \\
{[0.09]}\end{array}$ & & \\
\hline $\mathrm{LCF}>5$ years & & & & & $\begin{array}{l}-0.085 \\
{[-0.59]}\end{array}$ & $\begin{array}{l}-0.103 \\
{[-0.32]}\end{array}$ & & \\
\hline $\mathrm{LCF} \leq 5$ years $\times \mathrm{LRI}$ & & & & & & $\begin{array}{l}-0.035 \\
{[-0.04]}\end{array}$ & & \\
\hline $\mathrm{LCF}>5$ years $\times$ LRI & & & & & & $\begin{array}{r}0.057 \\
{[0.05]}\end{array}$ & & \\
\hline MINTAX & & & & & & & $\begin{array}{l}0.130^{*} \\
{[1.78]}\end{array}$ & $\begin{array}{r}0.012 \\
{[0.06]}\end{array}$ \\
\hline MINTAX $\times$ LRI & & & & & & & & $\begin{array}{c}0.481 \\
{[0.54]}\end{array}$ \\
\hline LRI & $\begin{array}{l}2.120^{* * *} \\
{[3.24]}\end{array}$ & $\begin{array}{l}2.122^{* * *} \\
{[3.24]}\end{array}$ & $\begin{array}{l}2.355^{* * *} \\
{[3.26]}\end{array}$ & $\begin{array}{l}2.120^{* * *} \\
{[3.22]}\end{array}$ & $\begin{array}{l}2.128^{* * *} \\
{[3.22]}\end{array}$ & $\begin{array}{l}2.132^{* *} \\
{[2.27]}\end{array}$ & $\begin{array}{l}2.118^{* * *} \\
{[3.23]}\end{array}$ & $\begin{array}{l}2.046^{* * *} \\
{[3.12]}\end{array}$ \\
\hline GDP BILAT & $\begin{array}{l}17.185^{* * *} \\
{[6.68]}\end{array}$ & $\begin{array}{l}17.195^{* * *} \\
{[6.69]}\end{array}$ & $\begin{array}{l}17.148^{* * *} \\
{[6.63]}\end{array}$ & $\begin{array}{l}17.248^{* * *} \\
{[6.30]}\end{array}$ & $\begin{array}{l}17.094^{* * *} \\
{[6.29]}\end{array}$ & $\begin{array}{l}17.091^{* * *} \\
{[6.26]}\end{array}$ & $\begin{array}{l}17.767^{* * * *} \\
{[6.89]}\end{array}$ & $\begin{array}{l}17.710^{* * *} \\
{[6.99]}\end{array}$ \\
\hline DIST & $\begin{array}{l}-0.001^{* * *} \\
{[-7.50]}\end{array}$ & $\begin{array}{l}-0.001^{* * *} \\
{[-7.50]}\end{array}$ & $\begin{array}{l}-0.001^{* * *} \\
{[-7.51]}\end{array}$ & $\begin{array}{l}-0.001^{* * *} \\
{[-7.52]}\end{array}$ & $\begin{array}{l}-0.001^{* * *} \\
{[-7.53]}\end{array}$ & $\begin{array}{l}-0.001^{* * *} \\
{[-7.54]}\end{array}$ & $\begin{array}{l}-0.001^{* * *} \\
{[-7.52]}\end{array}$ & $\begin{array}{l}-0.001^{* * *} \\
{[-7.52]}\end{array}$ \\
\hline CONTIG & $\begin{array}{l}0.829^{* * *} \\
{[5.86]}\end{array}$ & $\begin{array}{l}0.829^{* * *} \\
{[5.86]}\end{array}$ & $\begin{array}{l}0.829^{* * *} \\
{[5.87]}\end{array}$ & $\begin{array}{l}0.829^{* * *} \\
{[5.89]}\end{array}$ & $\begin{array}{l}0.829^{* * *} \\
{[5.89]}\end{array}$ & $\begin{array}{l}0.829^{* * *} \\
{[5.88]}\end{array}$ & $\begin{array}{l}0.831^{* * *} \\
{[5.93]}\end{array}$ & $\begin{array}{l}0.831^{* * *} \\
{[5.94]}\end{array}$ \\
\hline COMLEG & $\begin{array}{l}0.723^{* * *} \\
{[4.81]}\end{array}$ & $\begin{array}{l}0.724^{* * *} \\
{[4.81]}\end{array}$ & $\begin{array}{l}0.724^{* * *} \\
{[4.82]}\end{array}$ & $\begin{array}{l}0.723^{* * *} \\
{[4.81]}\end{array}$ & $\begin{array}{l}0.723^{* * *} \\
{[4.81]}\end{array}$ & $\begin{array}{l}0.723^{* * *} \\
{[4.81]}\end{array}$ & $\begin{array}{l}0.723^{* * *} \\
{[4.81]}\end{array}$ & $\begin{array}{l}0.723^{* * *} \\
{[4.80]}\end{array}$ \\
\hline AGGLO & $\begin{array}{l}4.714^{* * *} \\
{[4.88]}\end{array}$ & $\begin{array}{l}4.714^{* * *} \\
{[4.88]}\end{array}$ & $\begin{array}{l}4.764^{* * *} \\
{[5.02]}\end{array}$ & $\begin{array}{l}4.712^{* * *} \\
{[4.89]}\end{array}$ & $\begin{array}{l}4.719^{* * *} \\
{[4.89]}\end{array}$ & $\begin{array}{l}4.713^{* * *} \\
{[5.03]}\end{array}$ & $\begin{array}{l}4.714^{* * *} \\
{[4.89]}\end{array}$ & $\begin{array}{l}4.719^{* * *} \\
{[4.93]}\end{array}$ \\
\hline WAGES & $\begin{array}{l}0.000^{* *} \\
{[2.10]}\end{array}$ & $\begin{array}{l}0.000^{* *} \\
{[2.12]}\end{array}$ & $\begin{array}{l}0.000^{* *} \\
{[2.16]}\end{array}$ & $\begin{array}{l}0.000^{* *} \\
{[2.10]}\end{array}$ & $\begin{array}{l}0.000^{* *} \\
{[2.27]}\end{array}$ & $\begin{array}{l}0.000^{* *} \\
{[2.32]}\end{array}$ & $\begin{array}{l}0.000^{*} \\
{[1.86]}\end{array}$ & $\begin{array}{l}0.000^{*} \\
{[1.84]}\end{array}$ \\
\hline LR & $\begin{array}{l}-1.485^{* *} \\
{[-2.49]}\end{array}$ & $\begin{array}{l}-1.481^{* *} \\
{[-2.48]}\end{array}$ & $\begin{array}{l}-1.479^{* *} \\
{[-2.48]}\end{array}$ & $\begin{array}{l}-1.476^{* *} \\
{[-2.48]}\end{array}$ & $\begin{array}{l}-1.557^{* * *} \\
{[-3.04]}\end{array}$ & $\begin{array}{l}-1.566^{* * *} \\
{[-3.36]}\end{array}$ & $\begin{array}{l}-1.286^{* *} \\
{[-2.35]}\end{array}$ & $\begin{array}{l}-1.273^{* *} \\
{[-2.26]}\end{array}$ \\
\hline RISK & $\begin{array}{l}-0.251 \\
{[-0.31]}\end{array}$ & $\begin{array}{l}-0.278 \\
{[-0.33]}\end{array}$ & $\begin{array}{l}-0.255 \\
{[-0.30]}\end{array}$ & $\begin{array}{l}-0.255 \\
{[-0.32]}\end{array}$ & $\begin{array}{l}-0.231 \\
{[-0.28]}\end{array}$ & $\begin{array}{l}-0.228 \\
{[-0.28]}\end{array}$ & $\begin{array}{l}-0.242 \\
{[-0.31]}\end{array}$ & $\begin{array}{l}-0.190 \\
{[-0.23]}\end{array}$ \\
\hline JOINTEU & $\begin{array}{l}-0.014 \\
{[-0.20]}\end{array}$ & $\begin{array}{l}-0.014 \\
{[-0.20]}\end{array}$ & $\begin{array}{l}-0.015 \\
{[-0.22]}\end{array}$ & $\begin{array}{l}-0.013 \\
{[-0.20]}\end{array}$ & $\begin{array}{c}0.014 \\
{[0.23]}\end{array}$ & $\begin{array}{c}0.013 \\
{[0.23]}\end{array}$ & $\begin{array}{c}0.017 \\
{[0.25]}\end{array}$ & $\begin{array}{c}0.016 \\
{[0.24]}\end{array}$ \\
\hline Average marginal effect & & & & & & & & \\
\hline $\begin{array}{l}\text { STR } \\
\text { LCB }\end{array}$ & $\begin{array}{c}-0.605^{* * *} \\
0.064^{* *}\end{array}$ & $-0.608^{* * *}$ & $-0.611^{* * *}$ & $-0.612^{* * *}$ & $-0.588^{* * *}$ & $-0.589^{* * *}$ & $-0.598^{* * *}$ & $-0.599^{* * *}$ \\
\hline $\begin{array}{l}\mathrm{LCB}=1 \text { year } \\
\mathrm{LCB}>1 \text { year }\end{array}$ & & $\begin{array}{l}0.057^{*} \\
0.064^{* *}\end{array}$ & $\begin{array}{l}0.073^{* *} \\
0.065^{* * *}\end{array}$ & & & & & \\
\hline LCF LTD & & & & -0.004 & & & & \\
\hline $\mathrm{LCF} \leq 5$ years & & & & & 0.002 & 0.003 & & \\
\hline $\begin{array}{l}\text { LCF > } 5 \text { years } \\
\text { MINTAX }\end{array}$ & & & & & -0.014 & -0.015 & $0.022^{*}$ & $0.024^{*}$ \\
\hline Observations & 766,963 & 766,963 & 766,963 & 766,963 & 766,963 & 766,963 & 766,963 & 766,963 \\
\hline Pseudo R-squared & 0.211 & 0.211 & 0.212 & 0.211 & 0.212 & 0.212 & 0.212 & 0.212 \\
\hline
\end{tabular}

Notes: The table presents conditional logit parameter estimates from Equation C.5. The variable definitions are provided in the footnotes to Table C.5. All specifications include host country, industry and year fixed effects. Robust standard errors are clustered by host country. Z-statistics are given in brackets. ${ }^{*}, *$ and ${ }^{* * *}$ indicate statistical significance at the $10 \%, 5 \%$ and $1 \%$ level, respectively. 
probability and LRI. Part of the results obtained by Dreßler \& Overesch (2013) point in the same direction, which these authors interpret as indication "that investments tend to be higher where losses are reasonably anticipated" (Dreßler \& Overesch (2013, p. 525)). In the present case, the positive correlation may also reflect some kind of diversification efforts of the parent company in terms of spreading risk of loss occurrence across several companies.

In specifications 1 to 3 , I examine the location choice impact of loss carryback provisions. Specification 1 yields an AME of 0.064 for LCB which is statistically significant at the 5 percent level. In support of hypothesis H1, this indicates that offering a loss carryback increases the probability of new subsidiary location by 6.4 percentage points, on average. In specification 2 , $\mathrm{LCB}$ is split up into $\mathrm{LCB}=1$ year and $\mathrm{LCB}>1$ year to examine whether investors do not only consider the mere existence of a carryback provision but do also value their relative generosity in terms of how long in time losses can be carried back. I estimate related AMEs of 0.057 and 0.064 , respectively, the former being significant at the 10 percent level and the latter at the 5 percent level. Both the coefficients and the AMEs are of apparently similar size. A Wald test provides a formal confirmation on this: The null hypothesis that the difference between both coefficients is zero cannot be rejected under any conventional levels of significance $(p=0.75)$. Countries providing carryback periods of two years or more are thus not found to exhibit a statistically significant higher probability for new subsidiary location than countries with one-year carryback rules. Based on these findings, there is no empirical evidence in favour of hypothesis H2.

To explore the relation between the probability of location choice and carryback provisions more closely, specification 3 additionally includes interaction terms between LRI and LCB $=$ 1 year on the one hand and LCB $>1$ year on the other hand. Owing to the non-linearity of the applied regression model, the impact of the availability of loss carryback on the location choice probability differs for different values of LRI. Therefore, calculating marginal effects at representative values of LRI allows for a more differentiated assessment of the location choice impact of carryback availability. Figure C.3 provides a graphic representation of the marginal effects of $\mathrm{LCB}=1$ year and $\mathrm{LCB}>1$ year over a range of values of LRI between 0 and 1. The solid lines indicate the marginal effects, whereas the dashed lines reflect the lower and upper bounds of related 90 percent confidence intervals. From the figure, three things become clear. First, the positive investment impact associated with both dummies is only significant for LRI values in the range between 0 and 0.34 , indicated by the confidence intervals not encompassing zero. Given that some ninety percent of sample observations fall within this 
Figure C.3: Marginal effect of LCB $=1$ year and LCB $>1$ year on location probability as LRI changes

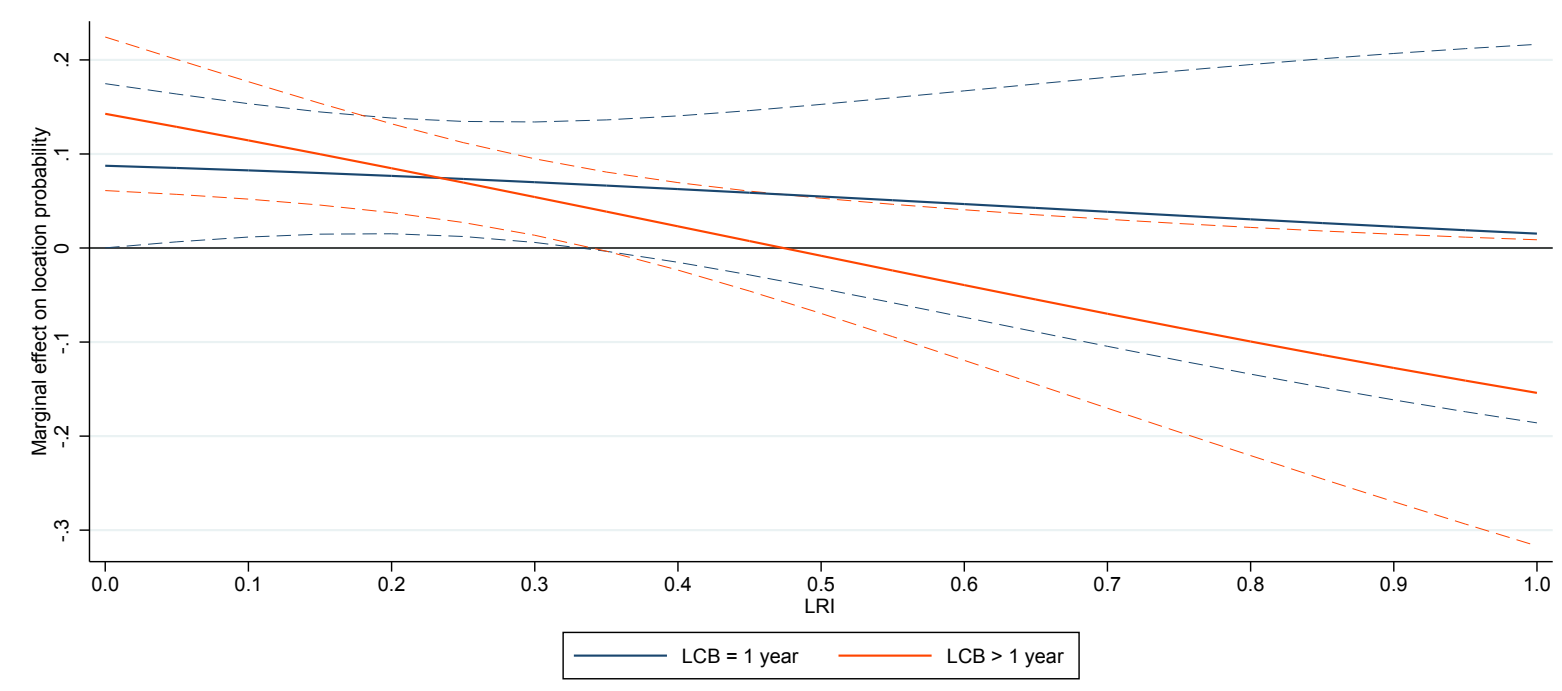

Source: Own figure. Dashed lines represent $90 \%$ confidence intervals.

range, the finding of a statistically significant positive investment impact of carryback provisions is to be considered substantive. Second, for LRI between 0 and approximately 0.23 , the figure suggests that carryback periods of more than one year have a more enhancing effect on location probability than only a one-year carryback period. However, the difference between the marginal effects of LCB $=1$ year and LCB $>1$ year is not statistically significant at any value of LRI. ${ }^{9}$ This suggests that it is in particular the very existence of a carryback opportunity that factors into MNE location decisions rather than the relative generosity of carryback rules. Third, the moderating role of LRI on the location impact of carryback provisions is different to what had been expected as the results do not point to a positive link between the marginal effects of loss carryback provisions and loss exposure but to an inverse relation instead. Since claiming a carryback requires the firm to have had positive taxable income in at least one year prior to the year of loss occurrence, a possible explanation for the decreasing shape of the curves could be that firms become less likely to successfully use a loss carryback provision when the basic risk to make a loss increases. This consideration finds no substantiation from an econometric point of view though. The difference between the marginal effect of $\mathrm{LCB}>1$ year evaluated at $\mathrm{LRI}=0$ on the one hand and at LRI $=0.34$ on the other hand turns out to be statistically insignificant $(p=0.18)$.

The location impact of time limitations on loss carryforwards is examined in specifications 4

$\overline{9}$ The difference in slopes is largest at LRI $=0$, carrying a p-value of roughly 0.22 . 
to 6 . In specification 4, I initially include LCF LTD which enters the regression with negative sign, as expected, but is insignificant. The same holds true for the AME estimate. These results point to an irrelevance of time restrictions in respect of location choices. Given the fact that the maximum utilisation periods vary widely for loss carryforwards (4 to 18 years), the apparent nil effect might be a result of a too rough measurement. While firms may believe there is a high risk of loss expiration when facing a 4-year carryforward period, the perceived difference between an 18-year carryforward period and an unlimited carryforward period may be small.

Therefore, I split up LCF LTD into LCF $\leq 5$ years and LCF $>5$ years in order to test if countries with short-term carryforward periods on the one hand and countries with longer-term carryforward periods on the other hand have a relatively smaller probability of attracting new subsidiaries from abroad, each in comparison to the group of countries offering time-unlimited carryforward. According to the results reported under specification 5 in Table C.6, the data do not provide evidence for this conjecture: in contrast to my expectations, both the associated coefficients and AME estimates turn out to be insignificant, which is opposite to hypothesis H5.

This result is underpinned when expanding the set of covariates by explicit interactions between LRI and the two proxy carryforward variables in specification 6. Figure C.4 reveals that the marginal effects of both variables lack statistical significance not only for average loss risk, but over the whole range of values of LRI. On this account, there is likewise no empirical evidence in support of hypothesis H6 which assumed that any negative impact of carryforward time limitations on location probability was intensified by increases in loss risk.

The last two model specifications are directed towards examining the role of minimum taxation provisions in location decisions. In specification 7 , the parameter estimate on MINTAX shows up positive and significant at the 10 percent level, indicating that the location probability is positively impacted by the application of a minium taxation rule. This finding contradicts theoretical expectations according to which a negative association was assumed. The AME of 0.022 implies that applying a minimum taxation on loss carryforwards increases the probability of attracting a new foreign-owned subsidiary by 2.2 percentage points, on average. Specification 8 again includes an interaction with LRI to study marginal effects at different values of LRI. From the related graph in Figure C.5 it appears that statistically siginicant positive effects of MINTAX are limited to the range of LRI values between 0.225 and 0.272 . Given that almost 30 percent of sample observations fall within this range, this finding requires further study. Yet, it should be borne in mind that primarily large countries had minimum taxation provisions in 
Figure C.4: Marginal effect of LCF $\leq 5$ years and LCF $>5$ years on location probability as LRI changes

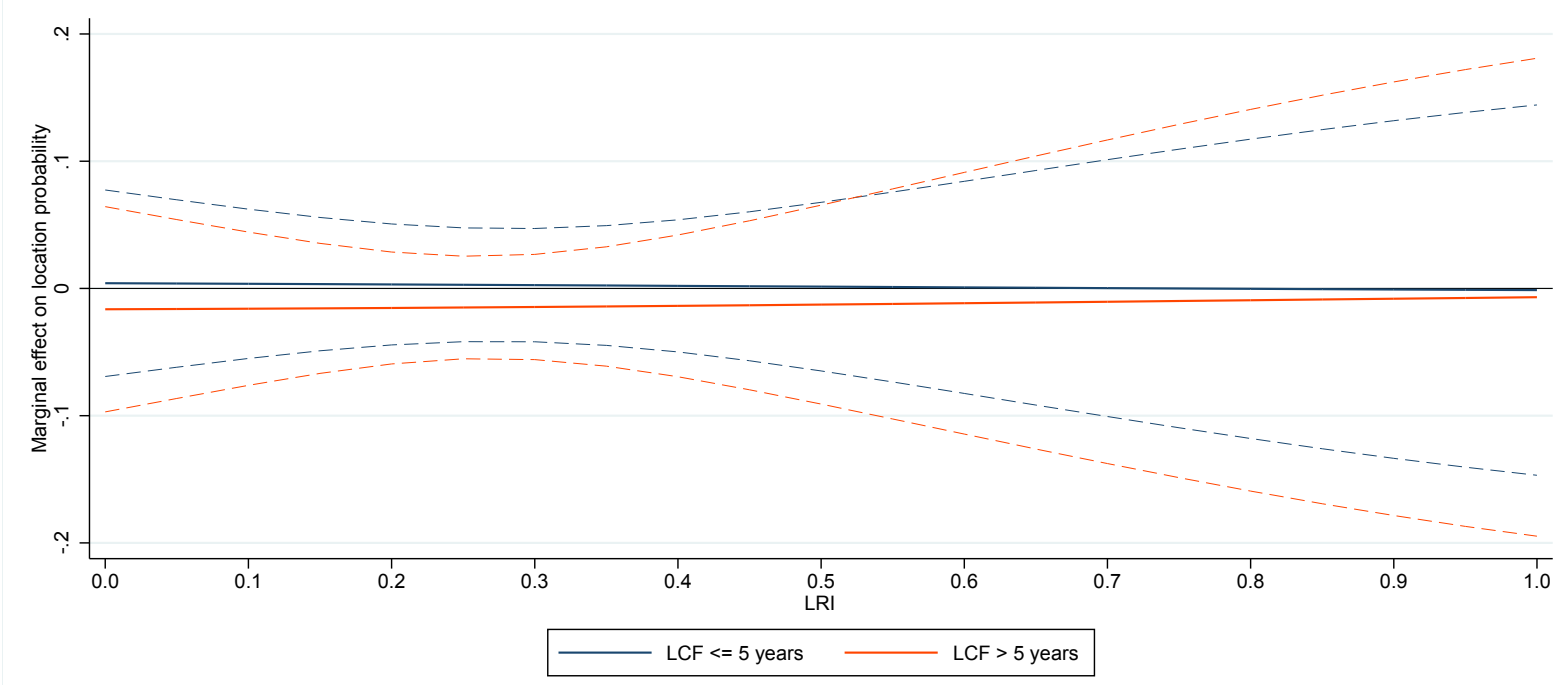

Source: Own figure. Dashed lines represent $90 \%$ confidence intervals.

Figure C.5: Marginal effect of MINTAX on location probability as LRI changes

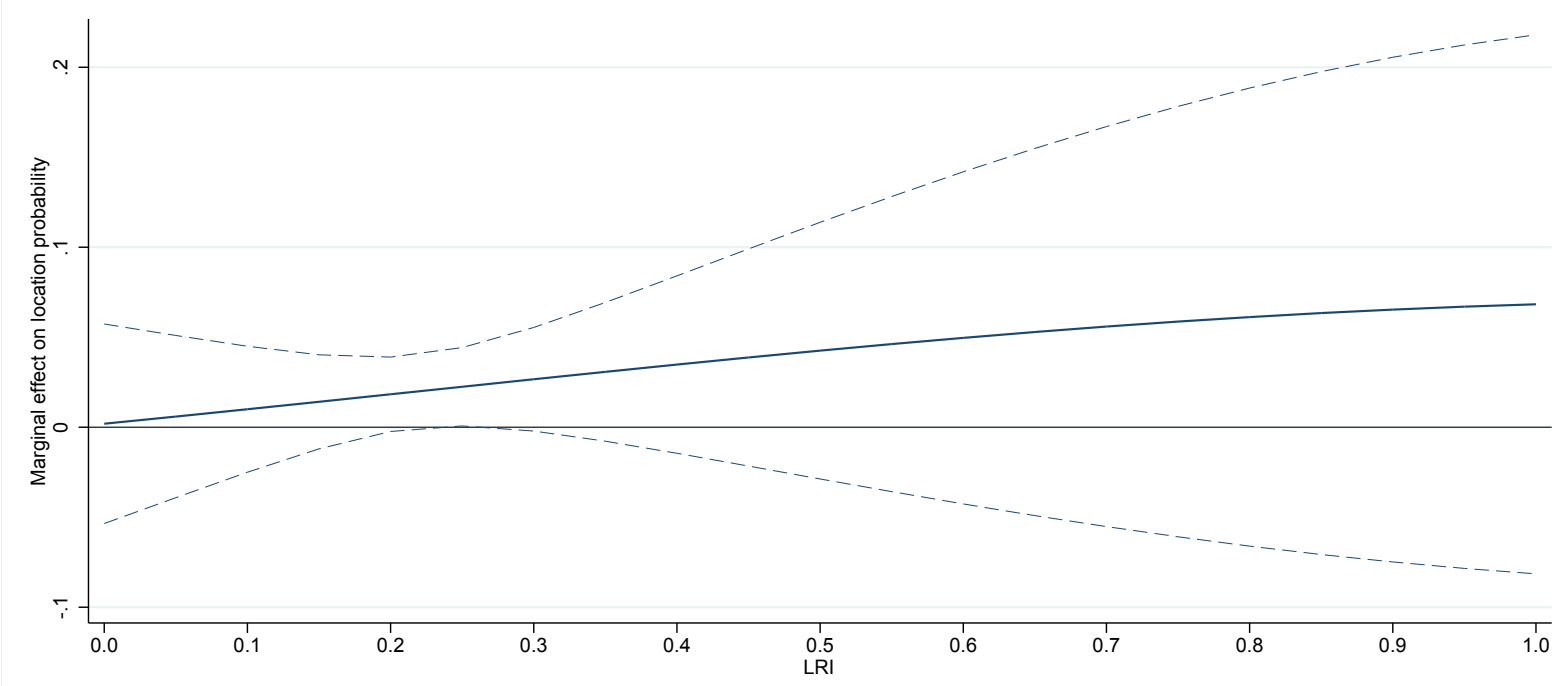

Source: Own figure. Dashed lines represent $90 \%$ confidence intervals.

their legislations and the data show fairly little variation in this regard. A descriptive look at the sample distribution of the data reveals that for 102,501 sample observations the MINTAX dummy takes on the value 1 , whereas in 664,462 cases it is 0 . At the same time, however, the former group of observations is associated with 0.09 subsidiary establishments on average, while the latter shows only 0.03 subsidiary establishments on average. Hence, there are considerably more subsidiary establishments observed for country-years with minimum taxation provisions in force than for country-years without. Below I shed further light on the robustness of the results 
against changes in the composition of the sample.

To end the evaluation of the baseline regressions' results, a brief glance shall be taken at the control variables. The relative size of the host country market impacts most strongly on the probability of location choice, both in terms of economic and statistical significance. The parameter estimates for DIST, CONTIG and COMLEG are indicative of a statistically strong negative relation between location probability and geographical or cultural distance between two countries. The statistically strong positive link between location probability and industry agglomeration confirms theoretical expectations. The estimate for the level of wages shows a positive effect on locational attractiveness which is conceivable because relatively high wages are a signal for a skilled workforce. A statistically significant negative location impact is exerted by borrowing costs.

\subsection{Sensitivity analyses}

To gauge the sensitivity of the above results, my preferred model specifications 3,6 and 8 are undergone several robustness tests. In a first instance, I use a different measure for loss exposure. Instead of making reference to the relative frequency of loss-reporting firms in a country/industry cell, I define loss exposure in terms of time by making reference to the average number of years it takes for newly established firms in a country-industry cell to realise a profit for the first time. The average duration of start-up loss periods is captured by the variable termed DSL. In this way, I account for the notion that the relation between location probability and the rigour of loss offset schemes should not only depend on the general probability of becoming subject to unfavourable tax treatment but also on how long such states are expected to last. Admittedly, this operationalisation of the temporal dimension of loss exposure is a very simple one and it cannot account for the whole complexity inherent to the dynamics of inter-temporal tax loss offset. But at least it provides me with an observable proxy to re-examine the existence of interactive effects of loss exposure from a different perspective. The parameter estimates relating to this first sensitivity analysis are reported in columns 1 to 3 of Table C.7.

Again, I use graphic representations to examine the marginal effects of the tax loss offset variables under scrutiny. Figure C.6 indicates that granting a loss carryback for one year or for more than one year has a statistically significantly positive impact on the location probability only for start-up loss periods of approximately 0.4 and 0.7 years, respectively. This may reflect 
Table C.7: Location probability and tax loss offset provisions-sensitivity analyses

\begin{tabular}{|c|c|c|c|c|c|c|c|c|c|c|c|c|c|c|c|}
\hline \multirow[b]{3}{*}{ STR } & \multicolumn{3}{|c|}{ DSL in place of LRI } & \multicolumn{3}{|c|}{ EATR in place of STR } & \multicolumn{3}{|c|}{ Excluding intermediate companies } & \multirow{2}{*}{$\begin{array}{l}\text { Excluding } \mathrm{I} \\
\quad(10)\end{array}$} & \multirow{2}{*}{\multicolumn{2}{|c|}{$\begin{array}{l}\text { FDI between } 2007 \text { and } 2009 \\
\begin{array}{ll}(11) & (12)\end{array}\end{array}$}} & \multirow{2}{*}{\multicolumn{3}{|c|}{$\begin{array}{l}\text { Excluding FDI from DE/GB/LU } \\
(13)\end{array}$}} \\
\hline & (1) & (2) & (3) & (4) & (5) & (6) & & & (9) & & & & & & \\
\hline & $\begin{array}{l}-3.597^{* * *} \\
{[-3.97]}\end{array}$ & $\begin{array}{l}-3.431^{* * *} \\
{[-3.29]}\end{array}$ & $\begin{array}{l}-3.506^{* * *} \\
{[-4.33]}\end{array}$ & $\begin{array}{l}-4.065^{* * *} \\
{[-4.43]}\end{array}$ & $\begin{array}{l}-3.961^{* * *} \\
{[-3.91]}\end{array}$ & $\begin{array}{l}-3.874^{* * *} \\
{[-4.73]}\end{array}$ & $\begin{array}{l}-4.192^{* * *} \\
{[-4.97]}\end{array}$ & $\begin{array}{l}-4.059^{* * *} \\
{[-4.05]}\end{array}$ & $\begin{array}{l}-4.076^{* * *} \\
{[-5.33]}\end{array}$ & $\begin{array}{l}-4.410^{* * *} \\
{[-4.48]}\end{array}$ & $\begin{array}{l}-4.339^{* * * *} \\
{[-3.96]}\end{array}$ & $\begin{array}{l}-4.335^{* * *} \\
{[-4.59]}\end{array}$ & $\begin{array}{l}-4.095^{* * *} \\
{[-4.85]}\end{array}$ & $\begin{array}{l}-3.746^{* * *} \\
{[-4.06]}\end{array}$ & $\begin{array}{l}-4.063^{* * *} \\
{[-4.87]}\end{array}$ \\
\hline $\mathrm{LCB}=1$ year & $\begin{array}{l}0.436^{* *} \\
{[2.18]}\end{array}$ & & & $\begin{array}{l}0.513^{*} \\
{[1.75]}\end{array}$ & & & $\begin{array}{l}0.712^{* *} \\
{[2.49]}\end{array}$ & & & $\begin{array}{l}0.645^{* *} \\
{[2.02]}\end{array}$ & & & $\begin{array}{l}0.515^{*} \\
{[1.66]}\end{array}$ & & \\
\hline LCB $>1$ year & $\begin{array}{l}0.476^{* *} \\
{[2.49]}\end{array}$ & & & $\begin{array}{l}0.871^{* * *} \\
{[3.55]}\end{array}$ & & & $\begin{array}{l}0.902^{* * *} \\
{[3.42]}\end{array}$ & & & $\begin{array}{l}0.882^{* * *} \\
{[3.31]}\end{array}$ & & & $\begin{array}{l}0.763^{* *} \\
{[2.52]}\end{array}$ & & \\
\hline $\mathrm{LCB}=1$ year $\times \mathrm{LRI}$ & $\begin{array}{l}-0.204 \\
{[-0.59]}\end{array}$ & & & $\begin{array}{l}-0.428 \\
{[-0.41]}\end{array}$ & & & -1.027 & & & -0.651 & & & 0.052 & & \\
\hline $\mathrm{LCB}>1$ year $\times$ LRI & $\begin{array}{l}-0.213 \\
{[-1.04]}\end{array}$ & & & $\begin{array}{l}-1.838^{* *} \\
{[-2.45]}\end{array}$ & & & $\begin{array}{l}{[-1.05]} \\
{\left[-1.627^{*}\right.} \\
{[-1.93]}\end{array}$ & & & $\begin{array}{l}-1.768^{* *} \\
{[-2.18]}\end{array}$ & & & $\begin{array}{l}-1.007 \\
{[-1.24]}\end{array}$ & & \\
\hline $\mathrm{LCF} \leq 5$ years & & $\begin{array}{l}-0.167 \\
{[-0.58]}\end{array}$ & & & $\begin{array}{r}0.035 \\
{[0.13]}\end{array}$ & & & $\begin{array}{l}-0.016 \\
{[-0.06]}\end{array}$ & & & $\begin{array}{r}0.063 \\
{[0.26]}\end{array}$ & & & $\begin{array}{c}0.154 \\
{[0.63]}\end{array}$ & \\
\hline $\mathrm{LCF}>5$ years & & $\begin{array}{l}-0.373 \\
{[-1.30]}\end{array}$ & & & $\begin{array}{l}-0.135 \\
{[-0.43]}\end{array}$ & & & $\begin{array}{l}-0.163 \\
{[-0.55]}\end{array}$ & & & $\begin{array}{r}-0.087 \\
{[-0.24]}\end{array}$ & & & $\begin{array}{r}-0.128 \\
{[-0.39]}\end{array}$ & \\
\hline $\mathrm{LCF} \leq 5$ years $\times$ LRI & & $\begin{array}{r}0.281 \\
{[1.01]}\end{array}$ & & & 0.007 & & & 0.089 & & & -0.259 & & & -0.164 & \\
\hline $\mathrm{LCF}>5$ years $\times$ LRI & & $\begin{array}{r}1.01] \\
0.420 \\
{[1.35]}\end{array}$ & & & $\begin{array}{l}{[0.01]} \\
0.139 \\
{[0.13]}\end{array}$ & & & $\begin{array}{l}0.11] \\
0.206 \\
{[0.21]}\end{array}$ & & & $\begin{array}{r}{[-0.36]} \\
0.048 \\
{[0.04]}\end{array}$ & & & $\begin{array}{r}{[-0.20]} \\
0.253 \\
{[0.24]}\end{array}$ & \\
\hline MINTAX & & & $\begin{array}{r}0.076 \\
{[0.51]}\end{array}$ & & & $\begin{array}{l}-0.003 \\
{[-0.02]}\end{array}$ & & & $\begin{array}{c}0.101 \\
{[0.47]}\end{array}$ & & & $\begin{array}{l}-0.012 \\
{[-0.07]}\end{array}$ & & & $\begin{array}{l}-0.014 \\
{[-0.06]}\end{array}$ \\
\hline MINTAX $\times$ LRI & & & $\begin{array}{l}0.077 \\
{[0.37]}\end{array}$ & & & $\begin{array}{r}0.497 \\
{[0.56]}\end{array}$ & & & $\begin{array}{c}0.170 \\
{[0.19]}\end{array}$ & & & $\begin{array}{r}0.560 \\
{[0.67]}\end{array}$ & & & $\begin{array}{r}0.179 \\
{[0.22]}\end{array}$ \\
\hline LRI & $\begin{array}{l}0.425^{* *} \\
{[2.10]}\end{array}$ & $\begin{array}{c}0.249 \\
{[1.45]}\end{array}$ & $\begin{array}{l}0.335^{*} \\
{[1.72]}\end{array}$ & $\begin{array}{l}2.355^{* * *} \\
{[3.26]}\end{array}$ & $\begin{array}{l}2.096^{* *} \\
{[2.23]}\end{array}$ & $\begin{array}{l}2.042^{* * *} \\
{[3.12]}\end{array}$ & $\begin{array}{l}2.229^{* * *} \\
{[2.88]}\end{array}$ & $\begin{array}{l}1.861^{* *} \\
{[1.97]}\end{array}$ & $\begin{array}{l}1.908^{* * *} \\
{[2.71]}\end{array}$ & $\begin{array}{l}2.388^{* * *} \\
{[3.27]}\end{array}$ & $\begin{array}{l}2.227^{* *} \\
{[2.33]}\end{array}$ & $\begin{array}{l}2.030^{* * *} \\
{[2.97]}\end{array}$ & $\begin{array}{l}1.863^{* *} \\
{[2.23]}\end{array}$ & $\begin{array}{l}1.813^{*} \\
{[1.81]}\end{array}$ & $\begin{array}{l}1.762^{* *} \\
{[2.23]}\end{array}$ \\
\hline GDP BILAT & $\begin{array}{l}17.145^{* * *} \\
{[6.79]}\end{array}$ & $\begin{array}{l}17.007^{* * *} \\
{[6.38]}\end{array}$ & $\begin{array}{l}17.678^{* * *} \\
{[7.15]}\end{array}$ & $\begin{array}{l}17.273^{* * *} \\
{[6.61]}\end{array}$ & $\begin{array}{l}17.130^{* * *} \\
{[6.28]}\end{array}$ & $\begin{array}{l}17.777^{* * *} \\
{[6.99]}\end{array}$ & $\begin{array}{l}17.046^{* * *} \\
{[5.90]}\end{array}$ & $\begin{array}{l}17.020^{* * *} \\
{[5.52]}\end{array}$ & $\begin{array}{l}17.695^{* * *} \\
{[6.12]}\end{array}$ & $\begin{array}{l}15.759^{* * *} \\
{[6.79]}\end{array}$ & $\begin{array}{l}15.804^{* * *} \\
{[6.28]}\end{array}$ & $\begin{array}{l}16.404^{* * *} \\
{[7.34]}\end{array}$ & $\begin{array}{c}1.244 \\
{[0.15]}\end{array}$ & $\begin{array}{c}0.682 \\
{[0.08]}\end{array}$ & $\begin{array}{l}1.423 \\
{[0.17]}\end{array}$ \\
\hline DIST & $\begin{array}{l}-0.001^{* * *} \\
{[-7.52]}\end{array}$ & $\begin{array}{l}-0.001^{* * *} \\
{[-7.53]}\end{array}$ & $\begin{array}{l}-0.001^{* * *} \\
{[-7.50]}\end{array}$ & $\begin{array}{l}-0.001^{* * *} \\
{[-7.50]}\end{array}$ & $\begin{array}{l}-0.001^{* * *} \\
{[-7.53]}\end{array}$ & $\begin{array}{l}-0.001^{* * *} \\
{[-7.51]}\end{array}$ & $\begin{array}{l}-0.001^{* * *} \\
{[-7.51]}\end{array}$ & $\begin{array}{l}-0.001^{* * *} \\
{[-7.53]}\end{array}$ & $\begin{array}{l}-0.001^{* * *} \\
{[-7.51]}\end{array}$ & $\begin{array}{l}-0.001^{* * *} \\
{[-8.05]}\end{array}$ & $\begin{array}{l}-0.001^{* * *} \\
{[-8.08]}\end{array}$ & $\begin{array}{l}-0.001^{* * *} \\
{[-8.09]}\end{array}$ & $\begin{array}{l}-0.001^{* * *} \\
{[-7.26]}\end{array}$ & $\begin{array}{l}-0.001^{* * *} \\
{[-7.25]}\end{array}$ & $\begin{array}{l}-0.001^{* * *} \\
{[-7.23]}\end{array}$ \\
\hline CONTIG & $\begin{array}{l}0.827^{* * *} \\
{[5.88]}\end{array}$ & $\begin{array}{l}0.827^{* * *} \\
{[5.92]}\end{array}$ & $\begin{array}{l}0.828^{* * *} \\
{[5.93]}\end{array}$ & $\begin{array}{l}0.829^{* * *} \\
{[5.88]}\end{array}$ & $\begin{array}{l}0.829^{* * *} \\
{[5.89]}\end{array}$ & $\begin{array}{l}0.831^{* * *} \\
{[5.94]}\end{array}$ & $\begin{array}{l}0.839^{* * *} \\
{[5.98]}\end{array}$ & $\begin{array}{l}0.839^{* * *} \\
{[5.99]}\end{array}$ & $\begin{array}{l}0.841^{* * *} \\
{[6.03]}\end{array}$ & $\begin{array}{l}0.832^{* * *} \\
{[6.01]}\end{array}$ & $0.832^{* * *}$ & $\begin{array}{l}0.835^{* * *} \\
{[6.11]}\end{array}$ & $\begin{array}{l}1.075^{* * *} \\
{[5.74]}\end{array}$ & $1.075^{* * *}$ & $\begin{array}{l}1.075^{* * *} \\
{[5.75]}\end{array}$ \\
\hline COMLEG & $\begin{array}{l}0.726^{* * *} \\
{[4.79]}\end{array}$ & $\begin{array}{l}0.726^{* * *} \\
{[4.79]}\end{array}$ & $\begin{array}{l}0.726^{* * *} \\
{[4.79]}\end{array}$ & $\begin{array}{l}0.724^{* * *} \\
{[4.82]}\end{array}$ & $\begin{array}{l}0.723^{* * *} \\
{[4.80]}\end{array}$ & $\begin{array}{l}0.723^{* * * *} \\
{[4.80]}\end{array}$ & $\begin{array}{l}0.719^{* * *} \\
{[4.42]}\end{array}$ & $\begin{array}{l}0.718^{* * *} \\
{[4.40]}\end{array}$ & $\begin{array}{l}0.717^{* * *} \\
{[4.40]}\end{array}$ & $\begin{array}{l}0.711^{* * *} \\
{[4.80]}\end{array}$ & $\begin{array}{l}0.711^{* * *} \\
{[4.79]}\end{array}$ & $\begin{array}{l}0.710^{* * *} \\
{[4.78]}\end{array}$ & $\begin{array}{l}0.639^{* * *} \\
{[3.01]}\end{array}$ & $\begin{array}{l}0.639^{* * *} \\
{[3.01]}\end{array}$ & $\begin{array}{l}0.640^{* * *} \\
{[3.02]}\end{array}$ \\
\hline AGGLO & $\begin{array}{l}4.734^{* * *} \\
{[5.04]}\end{array}$ & $\begin{array}{l}4.718^{* * *} \\
{[5.23]}\end{array}$ & $\begin{array}{l}4.796^{* * *} \\
{[5.34]}\end{array}$ & $\begin{array}{l}4.754^{* * *} \\
{[4.99]}\end{array}$ & $\begin{array}{l}4.706^{* * *} \\
{[5.01]}\end{array}$ & $\begin{array}{l}4.710^{* * *} \\
{[4.91]}\end{array}$ & $\begin{array}{l}4.756^{* * *} \\
{[5.01]}\end{array}$ & $\begin{array}{l}4.672^{* * *} \\
{[5.00]}\end{array}$ & $\begin{array}{l}4.670^{* * *} \\
{[4.87]}\end{array}$ & $\begin{array}{l}4.707^{* * *} \\
{[4.51]}\end{array}$ & $\begin{array}{l}4.606^{* * *} \\
{[4.49]}\end{array}$ & $\begin{array}{l}4.635^{* * *} \\
{[4.46]}\end{array}$ & $\begin{array}{l}4.899^{* * *} \\
{[4.07]}\end{array}$ & $\begin{array}{l}4.878^{* * *} \\
{[4.17]}\end{array}$ & $\begin{array}{l}4.893^{* * *} \\
{[4.13]}\end{array}$ \\
\hline WAGES & $\begin{array}{l}0.000^{* *} \\
{[2.14]}\end{array}$ & $\begin{array}{l}0.000^{* *} \\
{[2.24]}\end{array}$ & $\begin{array}{l}0.000^{*} \\
{[1.92]}\end{array}$ & $\begin{array}{l}0.000^{*} \\
{[1.77]}\end{array}$ & $\begin{array}{l}0.000^{*} \\
{[1.95]}\end{array}$ & $\begin{array}{c}0.000 \\
{[1.50]}\end{array}$ & $\begin{array}{l}0.000^{* *} \\
{[2.50]}\end{array}$ & $\begin{array}{l}0.000^{* * *} \\
{[2.67]}\end{array}$ & $\begin{array}{l}0.000^{* *} \\
{[2.17]}\end{array}$ & $\begin{array}{l}0.000^{*} \\
{[1.85]}\end{array}$ & $\begin{array}{l}0.000^{* *} \\
{[2.22]}\end{array}$ & $\begin{array}{l}0.000^{*} \\
{[1.68]}\end{array}$ & $\begin{array}{l}0.000^{*} \\
{[1.88]}\end{array}$ & $\begin{array}{l}0.000^{* *} \\
{[2.15]}\end{array}$ & $\begin{array}{l}0.000^{*} \\
{[1.70]}\end{array}$ \\
\hline LR & $-1.524^{* *}$ & $-1.632^{* * *}$ & $-1.328^{* *}$ & $-1.416^{* *}$ & $-1.520^{* * *}$ & $-1.247^{* *}$ & $-1.500^{* *}$ & $-1.594^{* * *}$ & $-1.284^{* *}$ & -0.970 & $-1.138^{*}$ & -0.743 & $-1.069^{*}$ & $-1.218^{* * *}$ & -1.021 \\
\hline RISK & -0.286 & $\begin{array}{l}{[-3.08]} \\
-0.266\end{array}$ & -0.261 & -0.181 & $\begin{array}{l}-0.05] \\
-0.133\end{array}$ & $\begin{array}{r}-2.059 \\
-0.099\end{array}$ & -0.683 & $\begin{array}{l}-0.039 \\
-0.639\end{array}$ & -0.611 & $\begin{array}{r}{[-1.50]} \\
0.043\end{array}$ & $\begin{array}{r}-1.90 \\
0.062\end{array}$ & $\begin{array}{r}{[-1.078} \\
0.078\end{array}$ & -0.370 & -0.284 & $\begin{array}{l}-0.359 \\
-0.359\end{array}$ \\
\hline JOINTEU & $\begin{array}{l}{[-0.34]} \\
-0.006 \\
{[-0.10]}\end{array}$ & $\begin{array}{r}{[-0.32]} \\
0.025 \\
{[0.38]}\end{array}$ & $\begin{array}{r}{[-0.33]} \\
0.026 \\
{[0.40]}\end{array}$ & $\begin{array}{l}{[-0.23]} \\
-0.004 \\
{[-0.06]}\end{array}$ & $\begin{array}{r}{[-0.17]} \\
0.028 \\
{[0.52]}\end{array}$ & $\begin{array}{r}{[-0.13]} \\
0.024 \\
{[0.34]}\end{array}$ & $\begin{array}{c}{[-0.80]} \\
-0.035 \\
{[-0.48]}\end{array}$ & $\begin{array}{l}{[-0.75]} \\
-0.003 \\
{[-0.04]}\end{array}$ & $\begin{array}{r}{[-0.74]} \\
-0.000 \\
{[-0.00]}\end{array}$ & $\begin{array}{r}{[0.05]} \\
-0.041 \\
{[-0.49]}\end{array}$ & $\begin{array}{r}{[0.08]} \\
-0.024 \\
{[-0.30]}\end{array}$ & $\begin{array}{r}{[0.09]} \\
-0.005 \\
{[-0.06]}\end{array}$ & $\begin{array}{r}{[-0.34]} \\
0.001 \\
{[0.02]}\end{array}$ & $\begin{array}{r}{[-0.26]} \\
0.043 \\
{[0.63]}\end{array}$ & $\begin{array}{r}{[-0.32]} \\
0.007 \\
{[0.12]}\end{array}$ \\
\hline Obser & 756,371 & 75 & 75 & 766,963 & 76 & & 673,962 & 673,962 & 673,962 & 530,859 & 530,859 & 530 & 736 & 51 & 518 \\
\hline Pseudo R-squared & 0.208 & 0.209 & 0.208 & 0.212 & 0.212 & 0.212 & 0.213 & 0.213 & 0.213 & 0.213 & 0.213 & 0.213 & 0.244 & 0.244 & 0.244 \\
\hline
\end{tabular}

Note: The table presents conditional logit parameter estimates from sensitivity analyses to Equation C.5. The variable definitions are provided in the footnotes to Table C.5. All specifications include host country, industry and year fixed effects. Robust standard errors are clustered by host country. Z-statistics are given in brackets. ${ }^{*}, * *$ and ${ }^{* * *}$ indicate statistical significance at the $10 \%, 5 \%$ and $1 \%$ level, respectively. 
Figure C.6: Marginal effect of LCB $=1$ year and LCB $>1$ year on location probability as DSL changes

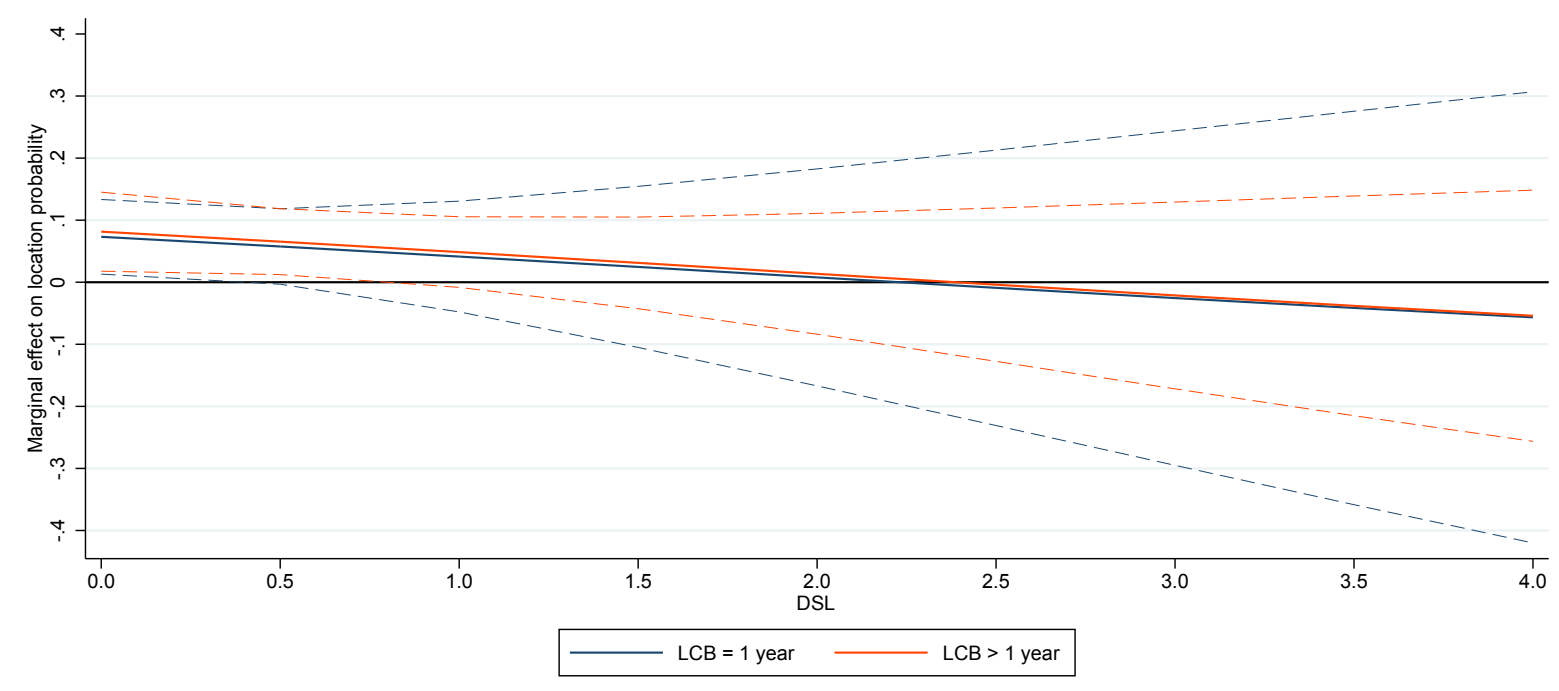

Source: Own figure. Dashed lines represent $90 \%$ confidence intervals.

uncertainty about the continued existence of carryback provisions in the future. A carryback provision that is in force today may have only minor importance for firms expecting to fall within the scope of the scheme only sometime in the future. Since claiming a carryback refund requires a firm to have had positive taxable income in a prior tax period, newly established firms can claim carryback relief no earlier than in their second year of existence, if not even later. At the time of decision making, there is thus uncertainty as to whether carryback relief will be still available in the future, and this uncertainty should be even more pronounced the longer the firm expects to incur start-up losses. Still, in approximately 55 percent of the sample observations, the marginal effect is estimated to be statistically significantly positive. Taken together with the results obtained when using the LRI proxy, the findings suggest that companies are incentivised by carryback allowances if it appears sufficiently probable that the related benefits can actually be realised.

As regards time and amount restrictions on loss carryforwards, Figures C.7 and C.8 suggest that corresponding provisions do not exert any statistically significant influence on MNE location choices. This underpins my findings from the baseline analysis.

A second set of robustness analyses addresses the concern that the disregard of tax base components other than loss carryover could have biased the baseline results. For example, there may be interrelations between tax loss offset and depreciation. Depreciation is favourable from a tax perspective if it lowers a positive tax base. But in case depreciation leads to an increase 
Figure C.7: Marginal effect of LCF $\leq 5$ years and LCF $>5$ years on location probability as DSL changes

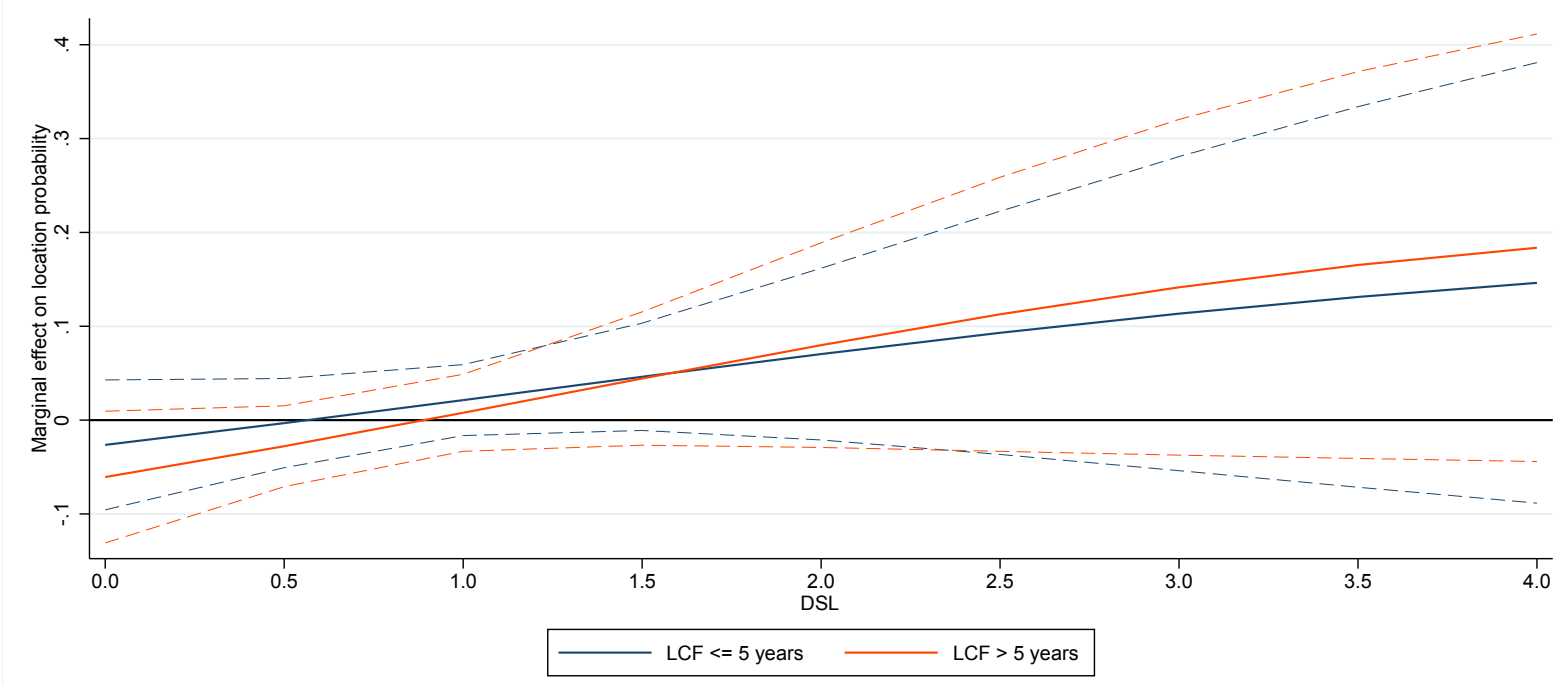

Source: Own figure. Dashed lines represent $90 \%$ confidence intervals.

Figure C.8: Marginal effect of MINTAX on location probability as DSL changes

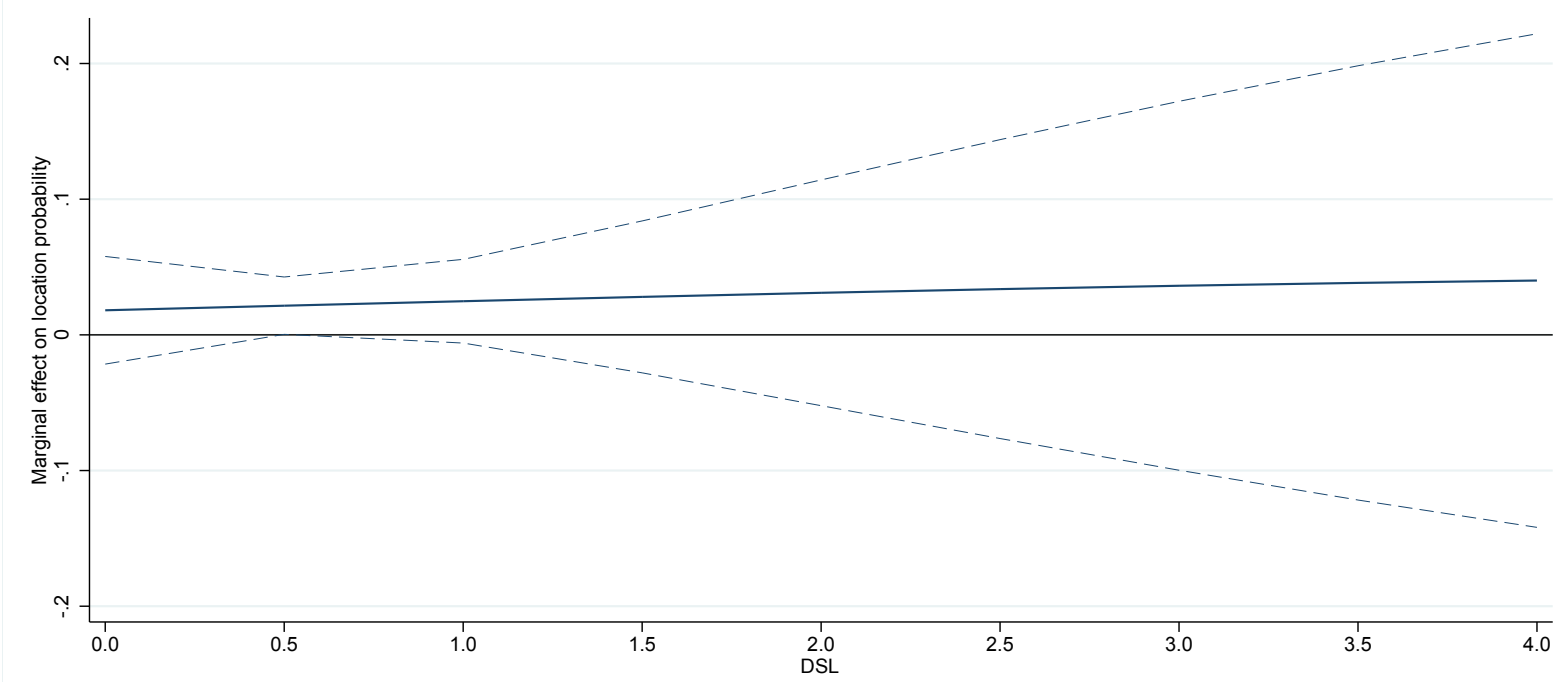

Source: Own figure. Dashed lines represent $90 \%$ confidence intervals.

in tax loss carryforwards, this might further aggrevate any negative effects of restrictive loss offset rules. To verify the baseline results are robust against such reciprocal dependencies, I reestimate my preferred model specifications with the effective average tax rate (EATR) in place of STR. The resultant coefficients displayed in columns 4 to 6 of Table C.7 are nearly identical to the corresponding baseline estimates. Figures C.9 and C.10 in the appendix attest that the tax rate definition has no notable influence on the conclusions drawn with respect to the estimated marginal effects for the dummy variables reflecting carryback and carryforward time limitations, 
respectively. Concerning the impact of minimum taxation regimes, however, Figure C.11 in the appendix shows that the unexpected positive and statistically significant association between location probability and MINTAX which arose over a non-negligible range of LRI values and was visualised in Figure C.5 is not robust against alternative tax rate definitions.

The parameter estimates in columns 7 to 9 of Table Table C.7 refer to a subsample of newly founded majority-owned companies that are not themselves parent companies. By focusing on two-tier group structures I aim at verifying my findings are not confounded by potentially opposed tax incentives for conduit companies. Suchlike entities are often lacking economic substance and are solely established in order to qualify for tax treaty benefits in favour of the whole group. Empirical evidence by Wamser (2011) indicates that the propensity to invest abroad via a conduit entity is positively related to the statutory tax rate in the host country. In my case, the regressions on the subsample of two-tier group structures yield economically and statistically stronger tax rate effects than the baseline regressions. At the same time, relatively little change can be seen with regard to the control variables. Inasmuch as the statutory tax burden is concerned it thus seems that having intermediate companies included in the sample actually results in an underestimation of tax effects. However, inspection of the marginal effect graphs for the loss offset variables (Figures C.12, C.13 and C.14 in the appendix) shows that this does not apply to the baseline findings regarding the impact of loss offset restrictions.

As illustrated in Figure C.2, during the economic downturn in the course of the global financial crisis beginning in 2007, the number of subsidiary establishments declined sharply until 2009. To check if my findings are robust against the external shock caused by the financial crisis, I exclude all subsidiary establishments between 2007 and 2009 and rerun the regressions. While the semielasticity of the location probability with respect to the statutory tax rate is now estimated to be considerably larger than in the baseline case (approximately -4.3 compared to approximately -3.5 in the baseline estimations), there is no noteworthy change in the marginal effect graphs for the loss carryback and carryforward time limitation variables. Nevertheless, I do not find any longer the previously occurring unexpected positive effects of minimum taxation provisions.

As a final robustness test, I drop all observations on subsidiary establishments where the investing company is resident in Germany, Luxembourg or the United Kingdom. Recall from Table C. 3 that these countries are home countries to the majority of newly established subsidiaries. The exclusion of this substantial part of the data leaves the results largely unaffected, 
apart from the parameter estimate on GDP BILAT which falls precipitously from around 17 to 1 and loses statistical significance completely. Most importantly, Figure C.18 still supports the conjecture that carryback provisions may incentivise subsidiary location, whereas Figure C.20 provides a further hint that the baseline finding of a positive association between location proability and minimum taxation regimes cannot be viewed as sufficiently robust.

\section{Conclusion}

The empirical results of this study contribute to the literature on the effects of taxation on MNE location choices. In contrast to prior research focusing primarily on profit considerations, this paper is the first to shed light on how asymmetric taxation in terms of inter-period loss offset limitations influences the decision where to locate a foreign subsidiary company. The motivation for examining this issue stems from the pronounced exposure to loss that companies are commonly facing in their first years of operation.

In general, my findings point to a minor importance of loss carryover provisions vis-à-vis countries' statutory tax burdens. Specifically, I do not find robust empirical evidence for a negative association between location probabilities and time- or amount-related restrictions on loss carryforwards. According to my findings, granting companies the right to carryback losses increases the probability of location choice by approximately 6 percentage points though. The results turn out to be insensitive to alternative tax rate definitions and the partial exclusion of specific observations.

There are two main limitations in my study. First, the AmAdeus data do not allow a traceability of historical ownership structures. Thus, I cannot rule out potential individual misclassifications of parent-subsidiary relationships existing at the time of subsidiary establishment. Second, the lack of observable data at the individual firm level leads to the implementation of proxy variables for loss exposure that reflect country/industry averages. Consequently, these variables' ability to reflect firms' expectations about the probability of loss occurrence and the persistence of start-up losses in a sufficiently appropriate manner is reliant on the assumption that related country/industry-level aggregates do actually enter location-decision processes of MNE in a serious way.

Fitting in the overall picture drawn from previous studies, my findings show that it is not possible to make a blanket statement as to whether or not the effects of tax base components are 
factored into corporate decisions. Rather, it may be inferred that firms actually respond to tax incentives as represented here by carryback allowances if it is sufficiently likely that the related benefits can effectively be realised. By contrast, potential downsides from restrictive loss offset rules appear not to be reasonably anticipated. 


\section{Appendix}

Figure C.9: Marginal effect of LCB $=1$ year and LCB $>1$ year on location probability as LRI changes-EATR in place of STR

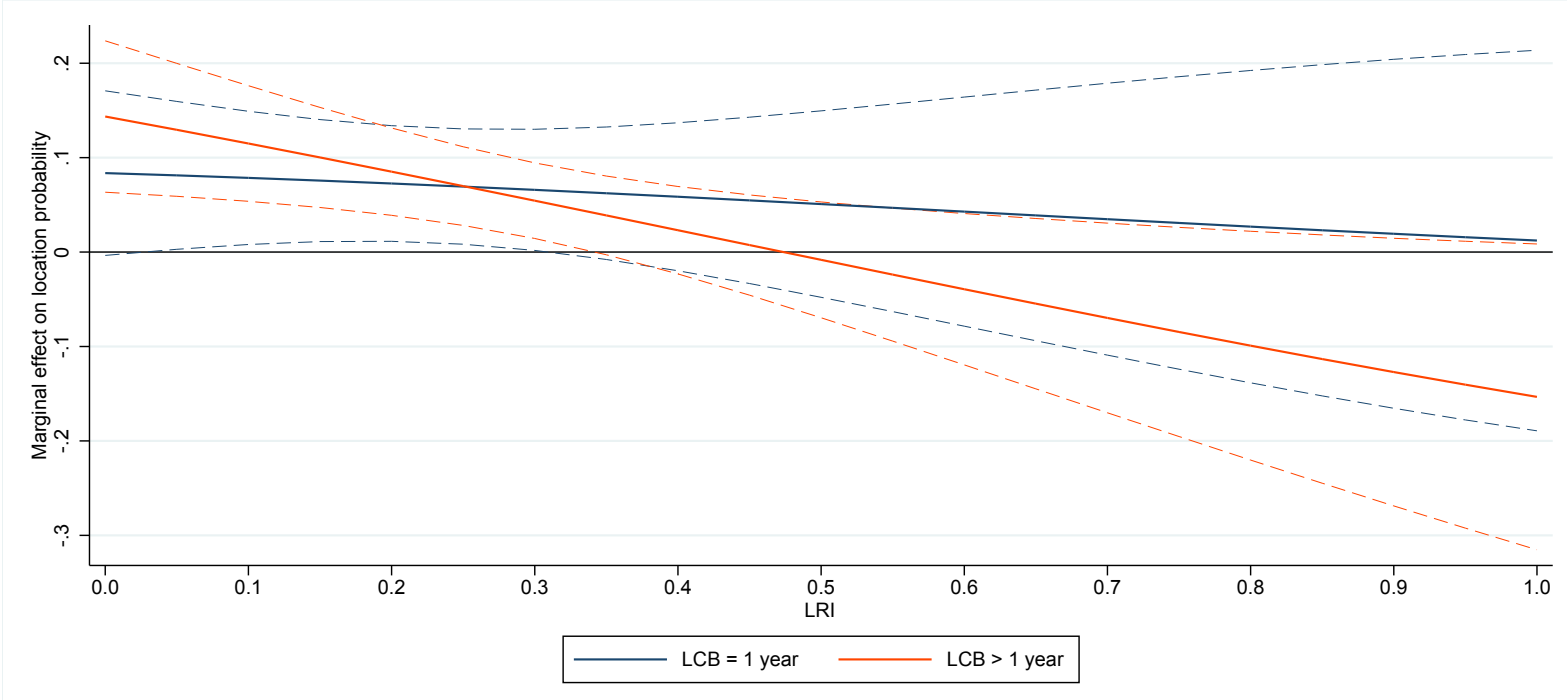

Source: Own figure. Dashed lines represent $90 \%$ confidence intervals.

Figure C.10: Marginal effect of LCF $\leq 5$ years and LCF $>5$ years on location probability as LRI changes-EATR in place of STR

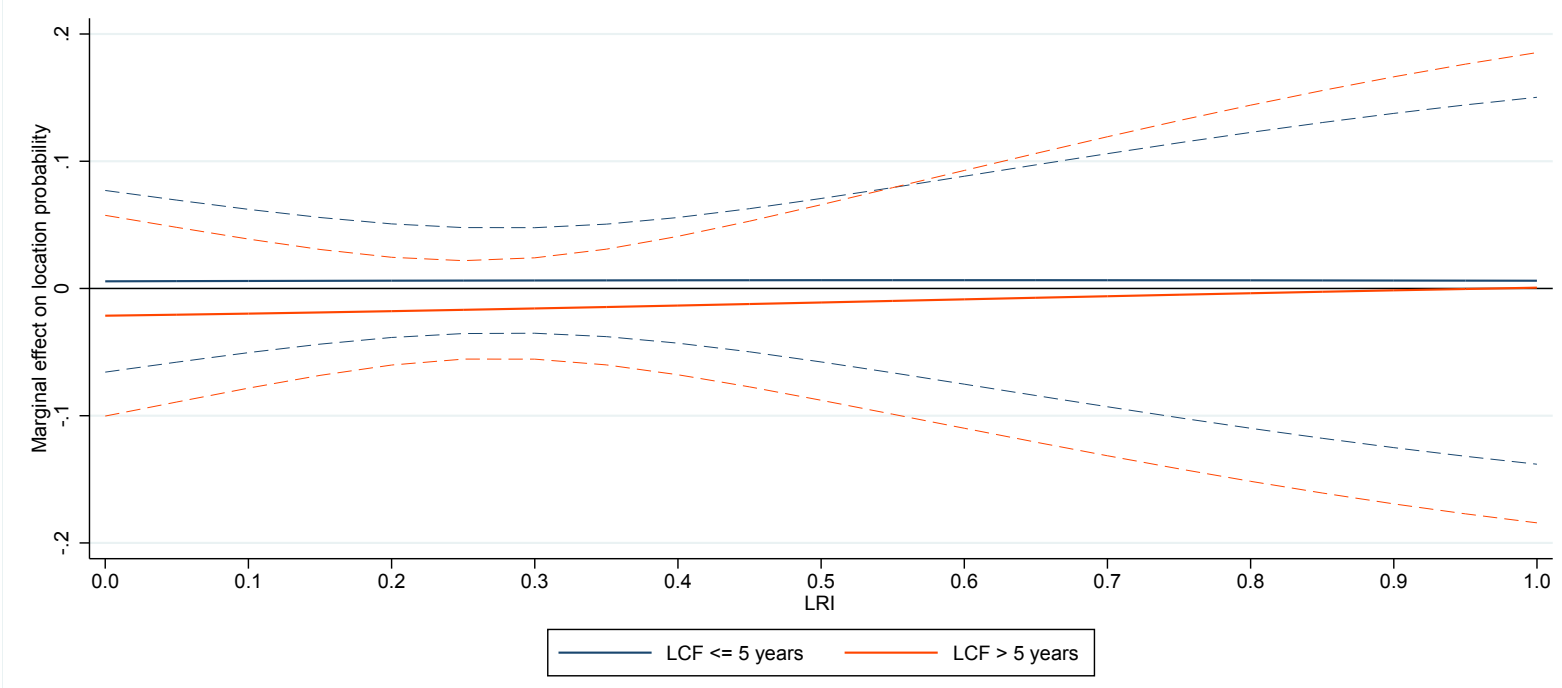

Source: Own figure. Dashed lines represent $90 \%$ confidence intervals. 
Figure C.11: Marginal effect of MINTAX on location probability as LRI changes-EATR in place of STR

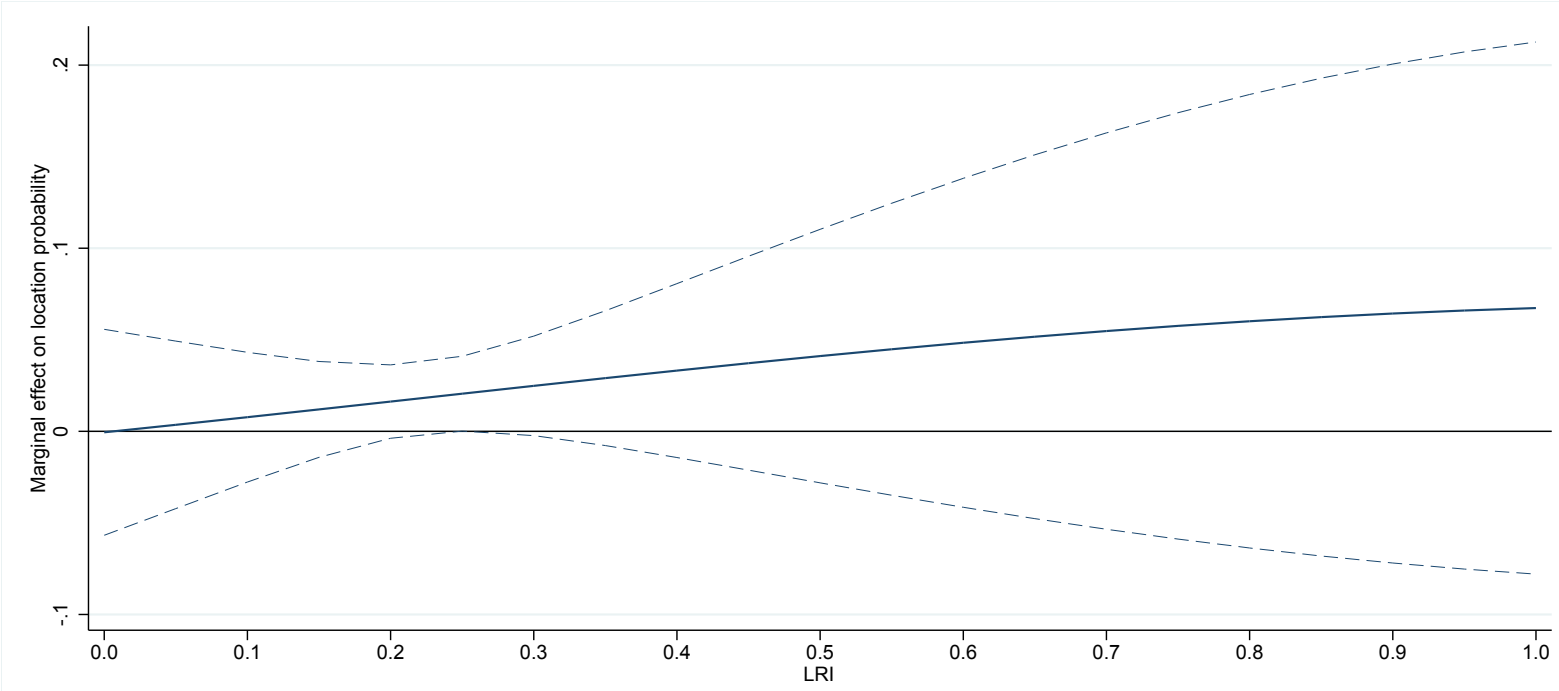

Source: Own figure. Dashed lines represent $90 \%$ confidence intervals.

Figure C.12: Marginal effect of LCB $=1$ year and LCB $>1$ year on location probability as LRI changesExcluding intermediate companies

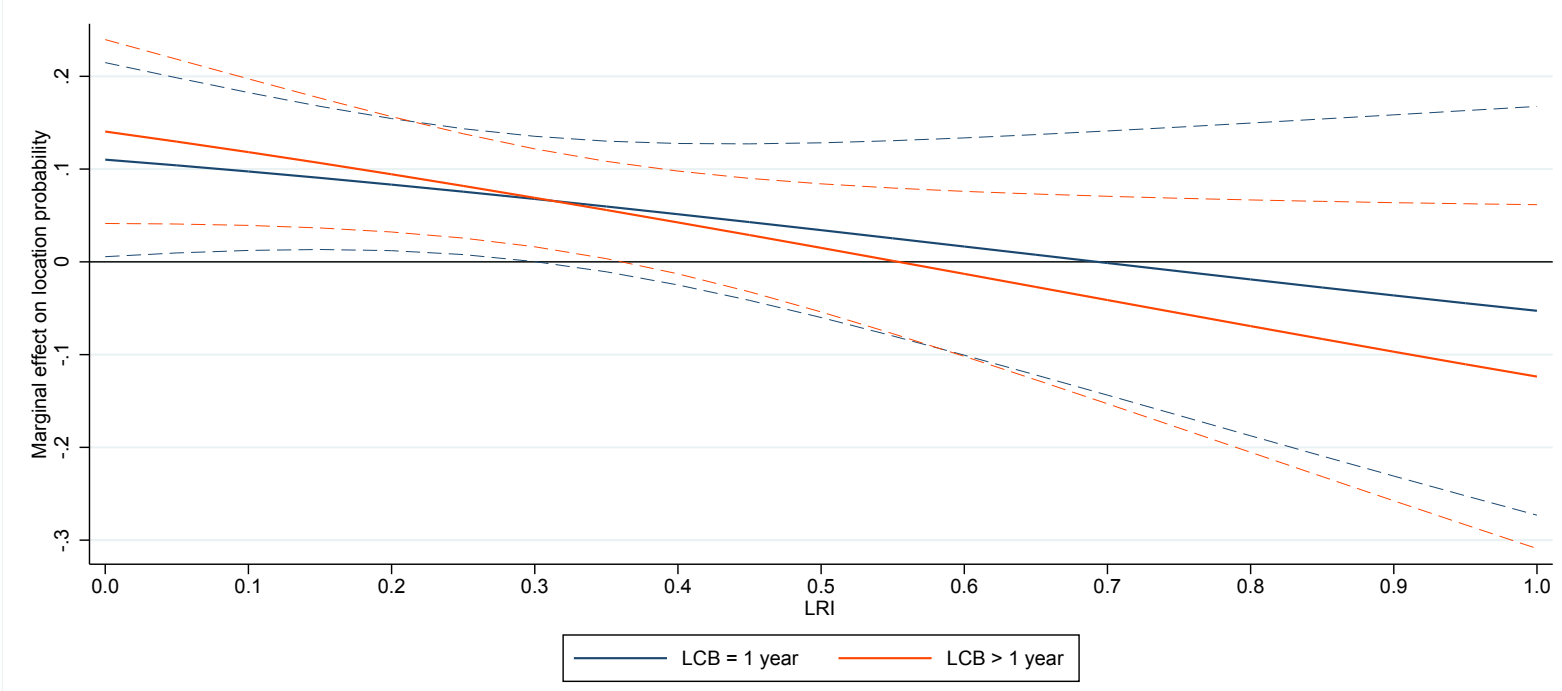

Source: Own figure. Dashed lines represent $90 \%$ confidence intervals. 
Figure C.13: Marginal effect of LCF $\leq 5$ years and LCF $>5$ years on location probability as LRI changesExcluding intermediate companies

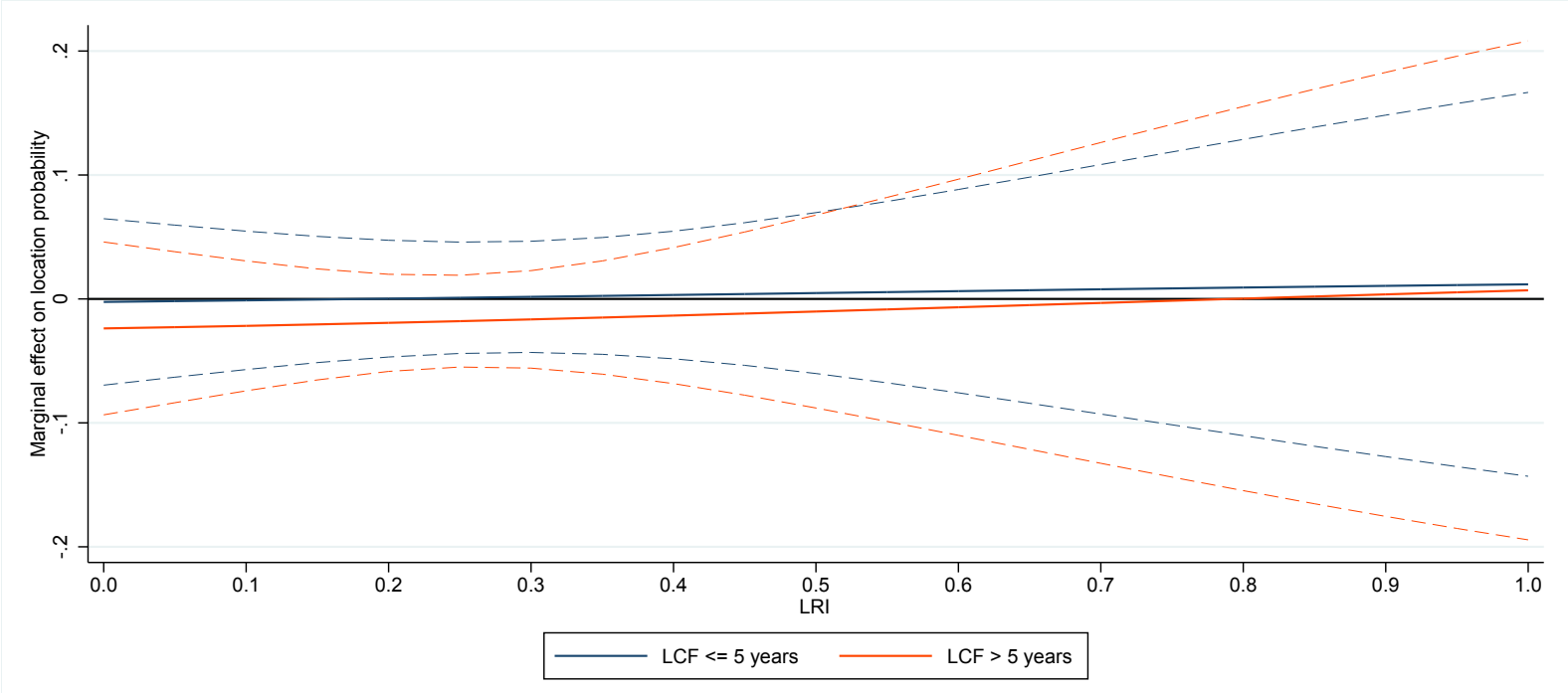

Source: Own figure. Dashed lines represent $90 \%$ confidence intervals.

Figure C.14: Marginal effect of MINTAX on location probability as LRI changes - Excluding intermediate companies

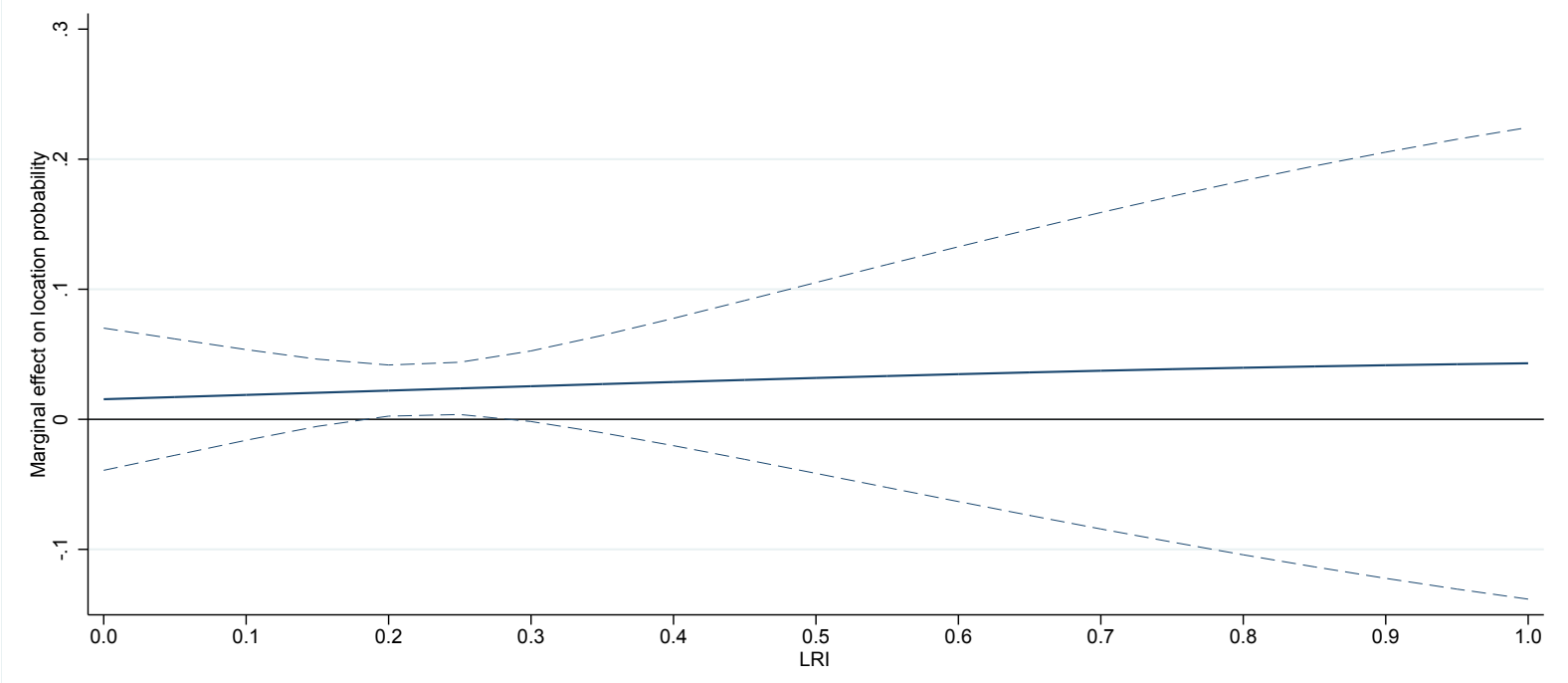

Source: Own figure. Dashed lines represent $90 \%$ confidence intervals. 
Figure C.15: Marginal effect of LCB $=1$ year and LCB $>1$ year on location probability as LRI changesExcluding FDI between 2007 and 2009

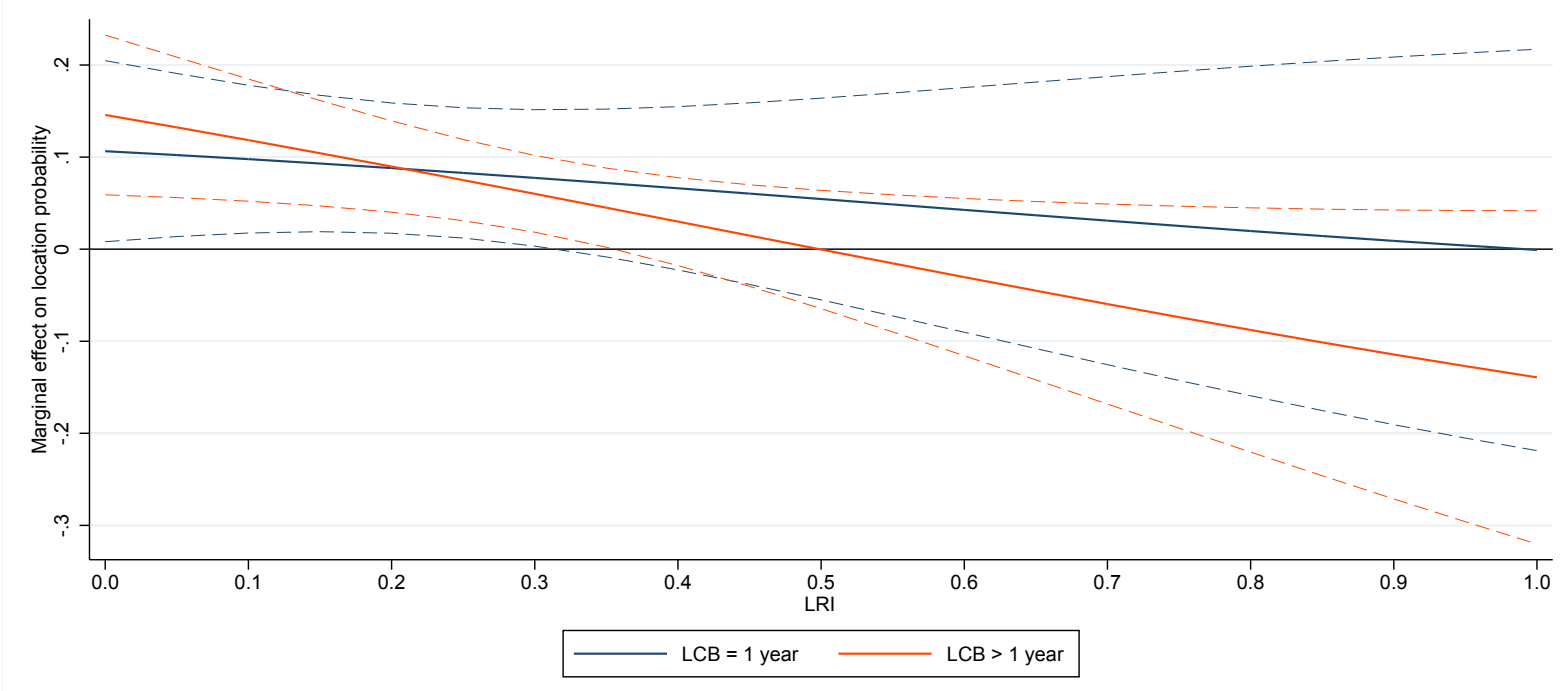

Source: Own figure. Dashed lines represent $90 \%$ confidence intervals.

Figure C.16: Marginal effect of LCF $\leq 5$ years and LCF $>5$ years on location probability as LRI changesExcluding FDI between 2007 and 2009

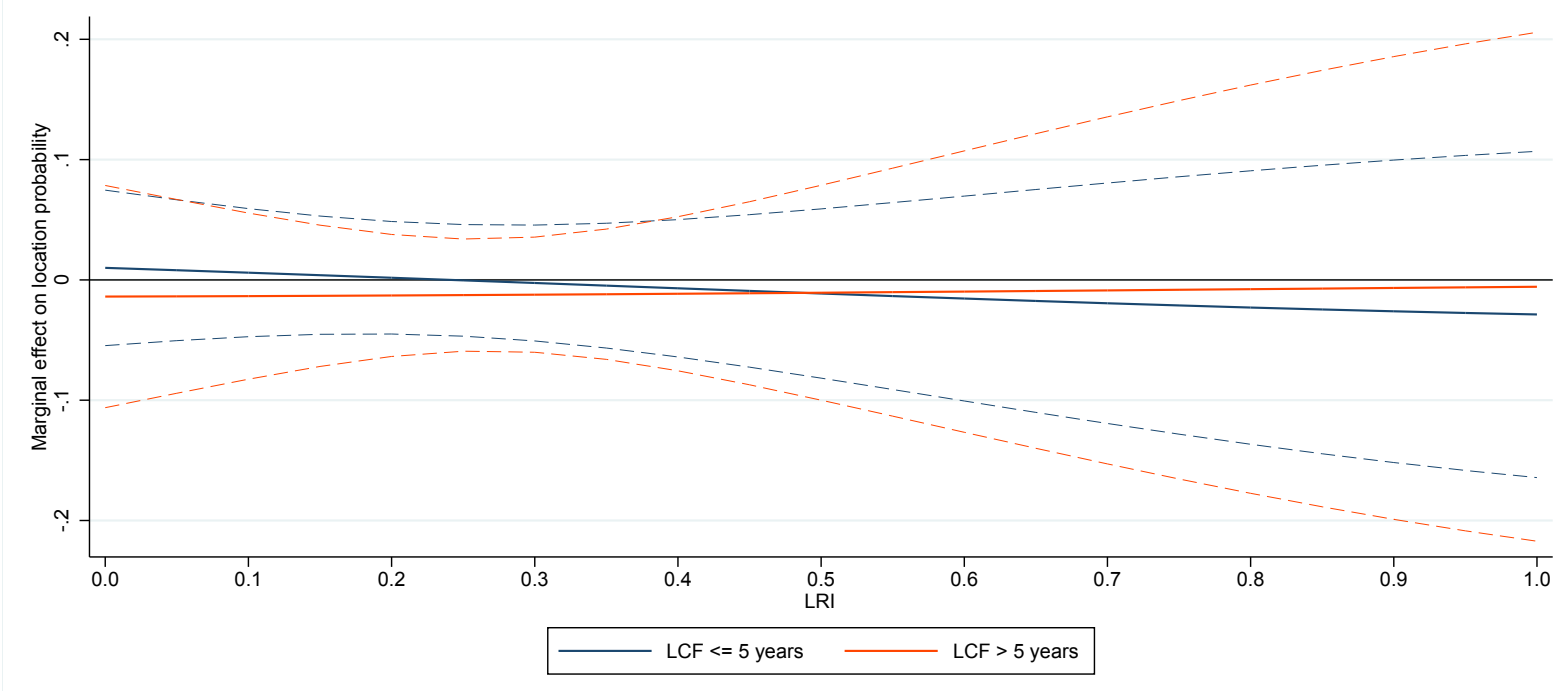

Source: Own figure. Dashed lines represent $90 \%$ confidence intervals. 
Figure C.17: Marginal effect of MINTAX on location probability as LRI changes-Excluding FDI between 2007 and 2009

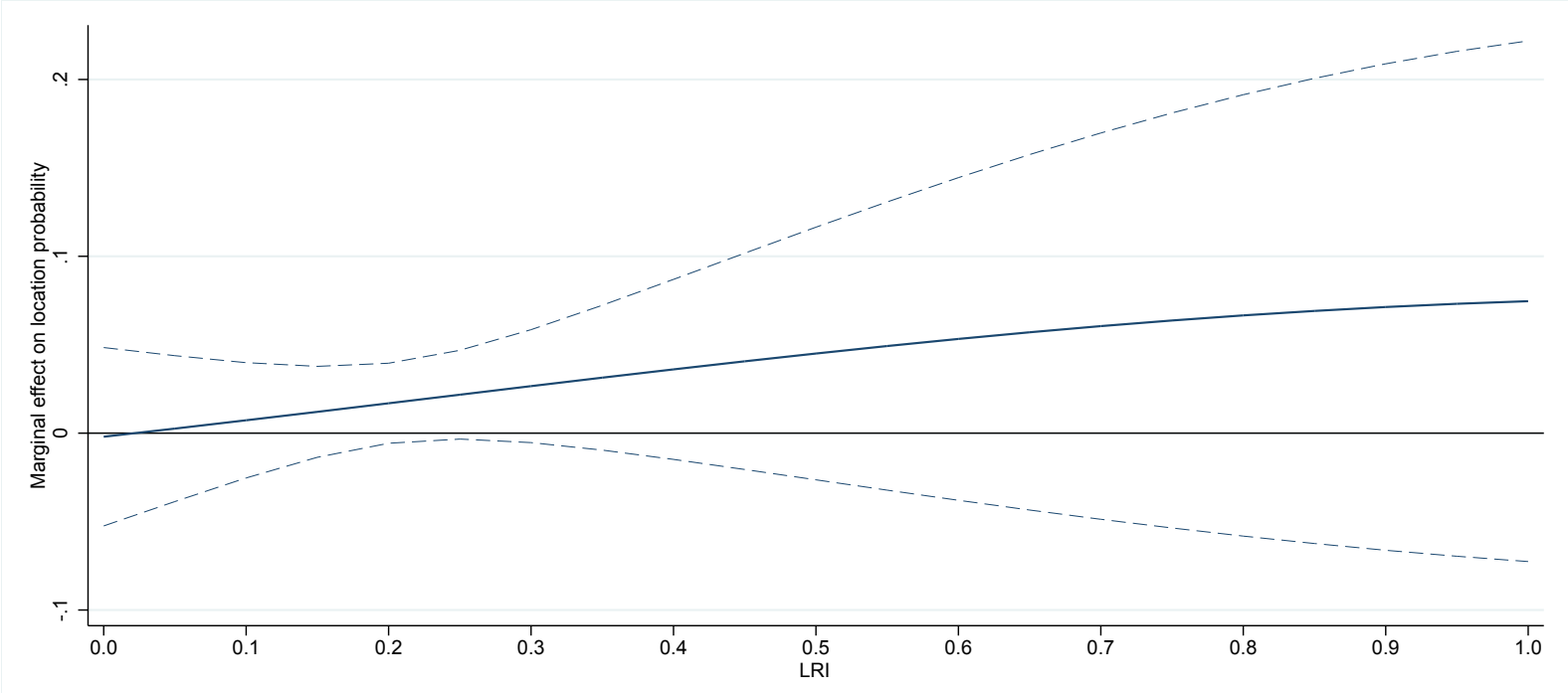

Source: Own figure. Dashed lines represent $90 \%$ confidence intervals.

Figure C.18: Marginal effect of LCB $=1$ year and LCB $>1$ year on location probability as LRI changesExcluding FDI from DE/GB/LU

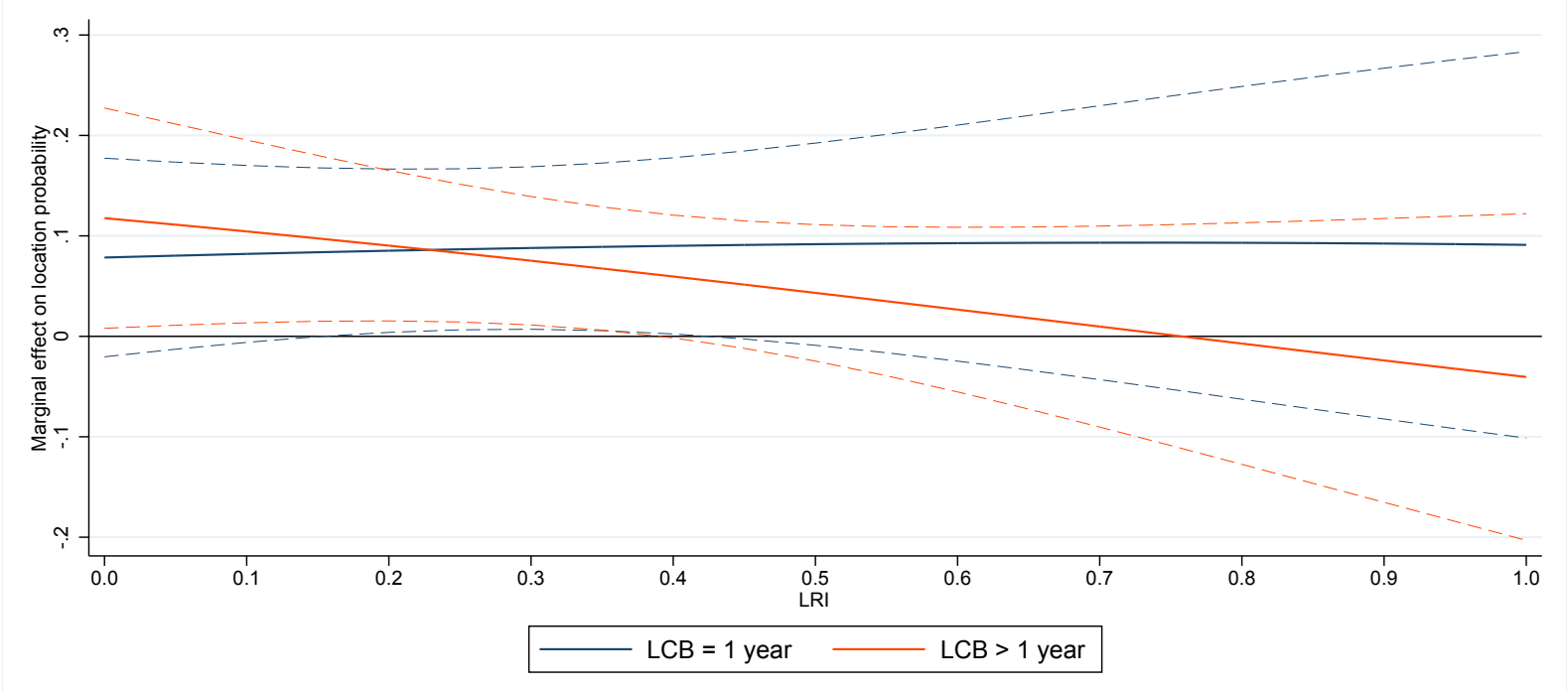

Source: Own figure. Dashed lines represent $90 \%$ confidence intervals. 
Figure C.19: Marginal effect of LCF $\leq 5$ years and LCF $>5$ years on location probability as LRI changesExcluding FDI from DE/GB/LU

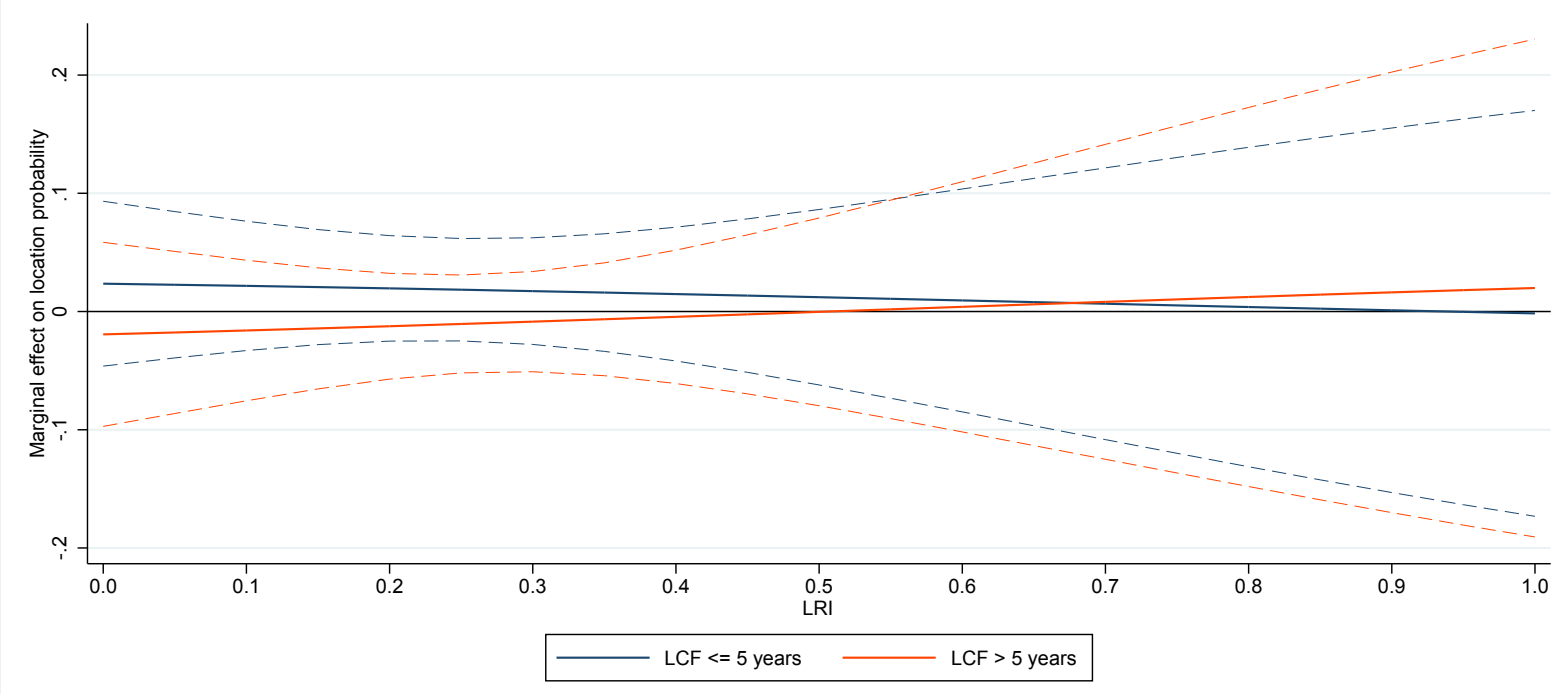

Source: Own figure. Dashed lines represent $90 \%$ confidence intervals.

Figure C.20: Marginal effect of MINTAX on location probability as LRI changes-Excluding FDI from $\mathrm{DE} / \mathrm{GB} / \mathrm{LU}$

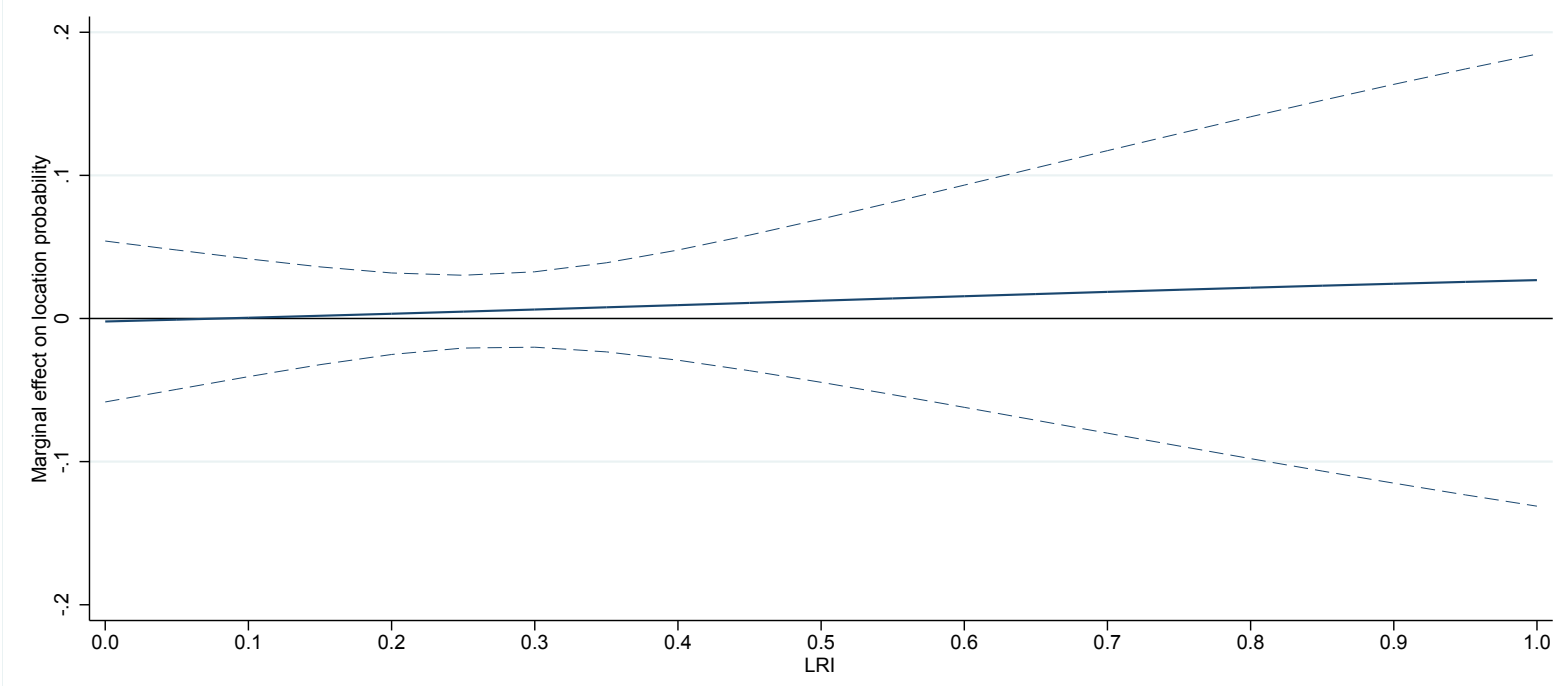

Source: Own figure. Dashed lines represent $90 \%$ confidence intervals. 
Table C.8: Correlation matrix

\begin{tabular}{|c|c|c|c|c|c|c|c|c|c|c|c|c|c|c|c|c|c|c|c|c|c|c|}
\hline & & (1) & (2) & (3) & (4) & (5) & (6) & (7) & (8) & (9) & (10) & (11) & (12) & (13) & (14) & (15) & (16) & (17) & (18) & (19) & (20) & (21) \\
\hline FDI & (1) & 1.000 & & & & & & & & & & & & & & & & & & & & \\
\hline STR & (2) & $0.048^{*}$ & 1.000 & & & & & & & & & & & & & & & & & & & \\
\hline EATR & (3) & $0.055^{*}$ & $0.962^{*}$ & 1.000 & & & & & & & & & & & & & & & & & & \\
\hline $\mathrm{LCB}$ & (4) & $0.079^{*}$ & $0.189^{*}$ & $0.283^{*}$ & 1.000 & & & & & & & & & & & & & & & & & \\
\hline $\mathrm{LCB}=1$ year & (5) & $0.079^{*}$ & $0.051^{*}$ & $0.129^{*}$ & $0.848^{*}$ & 1.000 & & & & & & & & & & & & & & & & \\
\hline LCB > 1 year & (6) & $0.015^{*}$ & $0.269^{*}$ & $0.315^{*}$ & $0.454^{*}$ & $-0.087^{*}$ & 1.000 & & & & & & & & & & & & & & & \\
\hline LCF LTD & (7) & $0.017^{*}$ & $-0.237^{*}$ & $-0.234^{*}$ & $-0.360^{*}$ & $-0.295^{*}$ & $-0.181^{*}$ & 1.000 & & & & & & & & & & & & & & \\
\hline $\mathrm{LCF} \leq 5$ years & (8) & $0.020^{*}$ & $-0.304^{*}$ & $-0.336^{*}$ & $-0.316^{*}$ & $-0.290^{*}$ & $-0.107^{*}$ & $0.684^{*}$ & 1.000 & & & & & & & & & & & & & \\
\hline LCF $>5$ years & (9) & -0.001 & $0.067^{*}$ & $0.109^{*}$ & $-0.078^{*}$ & $-0.026^{*}$ & $-0.103^{*}$ & $0.452^{*}$ & $-0.340^{*}$ & 1.000 & & & & & & & & & & & & \\
\hline MINTAX & (10) & $0.100 *$ & $0.103^{*}$ & $0.110^{*}$ & $0.043^{*}$ & $0.098^{*}$ & $-0.085^{*}$ & $-0.059^{*}$ & $0.040^{*}$ & $-0.125^{*}$ & 1.000 & & & & & & & & & & & \\
\hline LRI & (11) & $-0.027^{*}$ & $-0.177^{*}$ & $-0.233^{*}$ & $-0.317^{*}$ & $-0.273^{*}$ & $-0.137^{*}$ & $0.230^{*}$ & $0.177^{*}$ & $0.081^{*}$ & $-0.216^{*}$ & 1.000 & & & & & & & & & & \\
\hline DSL & (12) & $-0.013^{*}$ & $0.161^{*}$ & $0.114^{*}$ & $-0.078^{*}$ & $-0.055^{*}$ & $-0.055^{*}$ & $-0.008^{*}$ & $-0.028^{*}$ & $0.023^{*}$ & $0.030^{*}$ & $0.506^{*}$ & 1.000 & & & & & & & & & \\
\hline GDP BILAT & (13) & $0.144^{*}$ & $0.519^{*}$ & $0.615^{*}$ & $0.667^{*}$ & $0.559^{*}$ & $0.314^{*}$ & $-0.239^{*}$ & $-0.202^{*}$ & $-0.061^{*}$ & $0.243^{*}$ & $-0.388^{*}$ & $-0.146^{*}$ & 1.000 & & & & & & & & \\
\hline DIST & (14) & $-0.099^{*}$ & $-0.107^{*}$ & $-0.068^{*}$ & $-0.149^{*}$ & $-0.103^{*}$ & $-0.106^{*}$ & $0.125^{*}$ & 0.002 & $0.158^{*}$ & $-0.098^{*}$ & $-0.006^{*}$ & $-0.038^{*}$ & $-0.137^{*}$ & 1.000 & & & & & & & \\
\hline CONTIG & (15) & $0.142 *$ & $0.205^{*}$ & $0.185^{*}$ & $0.164^{*}$ & $0.094^{*}$ & $0.150^{*}$ & $-0.144^{*}$ & $-0.096^{*}$ & $-0.068^{*}$ & $0.155^{*}$ & $-0.079^{*}$ & $0.020^{*}$ & $0.210^{*}$ & $-0.435^{*}$ & 1.000 & & & & & & \\
\hline COMLEG & (16) & $0.053^{*}$ & $0.219^{*}$ & $0.221^{*}$ & $0.028^{*}$ & $-0.029^{*}$ & $0.102^{*}$ & $-0.015^{*}$ & $-0.063^{*}$ & $0.057^{*}$ & $-0.060^{*}$ & $0.006^{*}$ & $0.083^{*}$ & $0.048^{*}$ & $-0.138^{*}$ & $0.250^{*}$ & 1.000 & & & & & \\
\hline AGGLO & (17) & $0.005^{*}$ & $0.010^{*}$ & $0.015^{*}$ & -0.001 & $0.004^{*}$ & $-0.009^{*}$ & $-0.011^{*}$ & $-0.008^{*}$ & $-0.004^{*}$ & -0.002 & $-0.040^{*}$ & $0.051^{*}$ & 0.002 & $-0.027^{*}$ & $0.018^{*}$ & $0.019^{*}$ & 1.000 & & & & \\
\hline WAGES & (18) & $-0.010^{*}$ & $0.360^{*}$ & $0.380^{*}$ & $0.455^{*}$ & $0.440^{*}$ & $0.116^{*}$ & $-0.558^{*}$ & $-0.572^{*}$ & $-0.020^{*}$ & $0.011^{*}$ & $-0.149^{*}$ & $0.082^{*}$ & $0.328^{*}$ & $-0.110^{*}$ & $0.170^{*}$ & $0.103^{*}$ & -0.002 & 1.000 & & & \\
\hline LR & (19) & $0.026^{*}$ & $-0.237^{*}$ & $-0.226^{*}$ & $-0.236^{*}$ & $-0.250^{*}$ & $-0.022^{*}$ & $0.437^{*}$ & $0.370^{*}$ & $0.111^{*}$ & $-0.130^{*}$ & $0.220^{*}$ & $-0.058^{*}$ & $-0.191^{*}$ & $0.083^{*}$ & $-0.096^{*}$ & $-0.015^{*}$ & $-0.020^{*}$ & $-0.492^{*}$ & 1.000 & & \\
\hline RISK & (20) & $-0.013^{*}$ & $0.445^{*}$ & $0.437^{*}$ & $0.331^{*}$ & $0.310^{*}$ & $0.101^{*}$ & $-0.467^{*}$ & $-0.571^{*}$ & $0.096^{*}$ & $0.100^{*}$ & $-0.165^{*}$ & $0.155^{*}$ & $0.190^{*}$ & $-0.080^{*}$ & $0.150^{*}$ & $0.039^{*}$ & $0.012^{*}$ & $0.757^{*}$ & $-0.590^{*}$ & 1.000 & \\
\hline JOINTEU & (21) & $0.006^{*}$ & $0.097^{*}$ & $0.139^{*}$ & $0.137^{*}$ & $0.122^{*}$ & $0.052^{*}$ & $-0.270^{*}$ & $-0.373^{*}$ & $0.109^{*}$ & $0.042^{*}$ & $-0.119^{*}$ & $-0.042^{*}$ & $0.170^{*}$ & $0.005^{*}$ & $0.089^{*}$ & $0.089^{*}$ & -0.003 & $0.343^{*}$ & $-0.363^{*}$ & $0.240^{*}$ & 1.000 \\
\hline
\end{tabular}

Note: The table presents pair-wise Pearson correlations. ${ }^{*}$ indicates statistical significance at the $1 \%$ level. 


\title{
Kapitel D
}

\section{The sensitivity of simulated marginal tax rates to specific tax rules}

\begin{abstract}
This paper sheds light on the impact of various tax law provisions on the level of simulated marginal tax rates. In this connection, it offers a proposal for simulating marginal tax rates for European companies. The approach differs from existing approaches because it separates the process of income forecasting from the modelling of tax consequences, making it possible to examine the sensitivity of simulated marginal tax rates against specific tax rules. Descriptive evidence shows that the frequency distribution of simulated marginal tax rates changes most significantly when interest deductibility limitations and group taxation regimes are considered in the tax calculation, whereas it appears to be relatively robust against the incorporation of the tax treatment of dividend income and the modelling of notional interest deduction provisions. Yet, empirical tests suggest that the ability of simulated marginal tax rates to predict future corporate tax status is the higher the more tax rules are taken into account. Finally, the paper provides indication that simulated marginal tax rates derived from unconsolidated financial statements are more strongly correlated with firms' actual tax statuses than marginal tax rates based on simulated taxable income estimated from consolidated accounting data.
\end{abstract}

Keywords simulated marginal tax rates, tax law provisions, tax status, autoregressive model JEL classification C53, H20 


\section{Introduction}

One important strand of corporate tax research aims at empirically analysing the impact of tax provisions on business behaviour. Improving the knowledge about companies' responses to tax incentives is of great significance to both researchers and policy makers. From an academic perspective, empirical research verifies the quality of theoretical models and predictions and broadens the understanding of business decision-making in general. Besides, empirical evidence is of potential value for policy makers who are interested in evaluating the effectiveness of past tax reforms, or are wondering about the consequences of envisaged amendments to tax legislation.

In order for econometric studies using micro-level data to yield valid empirical evidence, it is of particular importance to appropriately measure the tax incentives related to the business decision under scrutiny. Furthermore, econometric identification requires the data to exhibit sufficient variation across companies and over time. Simulated marginal tax rates according to the concept of Shevlin (1987), Shevlin (1990) and Graham (1996b) have proven to be useful in this regard. Under this approach, the marginal tax rate of a company is defined as the change in the present value of current and future tax payments resulting from a marginal increase in the current year's taxable income. The approach provides for an explicit modelling of future income development under uncertainty and therefore allows for the consequences of inter-period tax loss offset to be taken into account. Companies that incur tax losses today may deduct their losses from profits in future or past periods by means of loss carry-forward or carry-back, respectively. As long as a marginal increase in taxable income can be offset in full against losses carried forward, those companies are in a quasi 'tax exempt' position.

Existing studies on capital structure choice using simulated marginal tax rates to model corporate tax status provide indication that the tax shield effect of loss carry-forwards does in fact mitigate the propensity of a company to finance with debt, as expected. This is so because the tax benefits from deducting interest expense cannot be fully realised, if at all, when the company is not taxed at the top marginal tax rate. Although related prior research consistently provides evidence for that relation in general, the estimated elasticities of simulated marginal tax rates are often found to be unexpectedly small. In addition, the use of simulated marginal tax rates does not regularly result in a noticeable gain in explanatory power of the regression models employed. This finding is particularly apparent in the few existing studies that apply the concept of simulated marginal tax rates to examinations of corporate investment behaviour.

Against this background, this paper aims, firstly, at making a conceptual contribution by 
discussing potential methodological reasons for why previous efforts at incorporating tax asymmetries into simulated marginal tax rates did not result in a more powerful identification of corporate tax incentives in empirical analyses. In this connection, it is of particular relevance that the majority of related work is about the effects of taxation on decisions of U.S. companies. Owing to some peculiarities of the U.S. legislation, I argue that it is not appropriate to apply the Shevlin (1987) methodology as it stands to the European context. In this connection, my second contribution is to provide a proposal for how to simulate marginal tax rates for European companies and generate a large panel dataset of simulated marginal tax rates for EU-resident companies over the time period 2003 to 2013. Instead of forecasting indirectly obtained estimates of taxable income based on consolidated financial statement data as is commonly done in studies from the U.S., I suggest to autonomously project unconsolidated pre-tax income into the future and to use the resulting income pattern as a basis for explicitly determining taxes due. In doing so, I take into consideration a greater variety and depth of relevant tax provisions. In addition to the modelling of inter-period loss offset rules, in calculating tax due I incorporate the effects of dividend exemption provisions, interest deductibility limitations, notional interest deduction rules, national group taxation regimes and targeted tax rates.

By gradually augmenting the scope of tax rules recognised in the simulation, I am able to test for the sensitivity of simulated marginal tax rates to specific tax rules. The descriptive analysis shows that the frequency distribution of simulated marginal tax rates is particularly sensitive to the inclusion of interest deductibility limitation rules and group taxation provisions. In comparison, neither the tax treatment of dividend income nor notional interest deduction allowances appear to have a similarly strong influence on the distribution of simulated marginal tax rates. Using a simple linear regression through the origin model, I examine how well simulated marginal tax rates of varying 'content' and complexity perform in capturing corporate tax status as actually realised. I find that the more tax law provisions are captured in the calculation of simulated marginal tax rates, the higher are the latter correlated with my empirical construct for actually realised tax status. Extending the scope of tax rules beyond the provisions governing inter-period loss offset leads to a significant increase in explained variance of my empirical construct for actually realised tax status. Furthermore, the empirical findings indicate that simulated marginal tax rates obtained under the approach presented in this paper are more highly correlated with actually realised tax statuses of European companies than simulated marginal tax rates derived under the 'traditional' U.S. approach of forecasting indirectly 
estimated taxable income.

The remainder of this paper is structured as follows. In Section 2, I begin by reviewing extant literature on approaches to simulating marginal tax rates and summarise related empirical findings. In Section 3, I discuss core methodological aspects of previous work and argue where deviations from those approaches appear necessary in order to prepare a basis for simulating marginal tax rates for European companies. In Section 4, I set out in detail the technical implementation of my simulation procedure. An evaluation of the resultant tax rate proxies is carried out in Section 5 and Section 6 concludes the paper.

\section{Review on existing approaches to simulating marginal tax rates and related literature}

\subsection{Random walk approach}

Shevlin (1987) analyses the determinants of U.S. R\&D companies to finance their activities through limited partnership structures rather than through in-house funding sources. Regarding the tax motivation of doing so, the author argues that low-tax companies should prefer the former because limited partnerships offer them increased certainty to realise tax benefits from deducting their R\&D expenditures. Companies experience low marginal tax rates if their earnings performance is poor or they have carry-forward losses from prior years. Such 'taxexhausted' companies cannot deduct $\mathrm{R} \& \mathrm{D}$ expenditures at the top statutory tax rate or have to defer (part of) the deduction to the uncertain future. This raises the cost of capital and, therefore, low-tax companies would be better off transferring their tax benefits to relatively high-taxed limited partnerships. This is all the more true if debt is used as financing source. To empirically analyse these relations, Shevlin (1987) uses, inter alia, simulated marginal tax rates as tax status proxies. To calculate them, the author assumes a company's taxable income before loss-offset to follow a random walk with drift:

$$
T I_{i, t}=T I_{i, t-1}+\epsilon_{i, t}, \quad \epsilon_{i, t} \stackrel{i i d}{\sim} \mathcal{N}\left(\mu_{i}, \sigma_{i}^{2}\right)
$$

where $T I_{i, t}$ denotes company $i$ 's taxable income in year $t$, which is forecasted until year $T$ using the company-specific parameters $\mu_{i}$ and $\sigma_{i}^{2}$. Both the mean value of first differences in taxable income, $\mu_{i}{ }^{1}$ and its variance, $\sigma_{i}^{2}$, are estimated from data on the earnings development in the

1 Graham (1996b, p. 206) proposes to constrain $\mu_{i}$ to be nonnegative. This avoids the unrealistic implication that companies that were unprofitable in the past will never become profitable again in the future. 
years prior to simulation year $t$, as reported in the companies' consolidated financial statement accounts. Lacking public access to tax data, taxable income is estimated by subtracting from reported pre-tax book income the change in the deferred tax account, with the latter 'grossed up' by the statutory marginal tax rate. ${ }^{2}$ To derive tax payments, the provisions governing tax loss carry-back and carry-forward as of year $t$ are applied on the forecasted values of $T I_{i, t}$ for $t$ to $T$ and the resultant annual tax bases are multiplied by the statutory tax rate applicable in $t$. Then, the projected value of $T I_{i, t}$ is incrementally increased by $\$ 1$, whereas the projected values for $t+1$ to $T$ remain unchanged, and the resultant tax payments are recalculated. The marginal tax rate is defined as the difference between the present values of the tax payable series after and before the incremental income increase. In order to account for the uncertainty of future earnings development, 50 simulation runs are performed for each company and the average is used as estimate of the marginal tax rate. While for an alternatively constructed instrumental variable tax measure, Shevlin (1987) consistently obtains statistically significant negative estimates, as expected, he is unable to do so for the simulated marginal tax rate which proves statistically significantly negative only in certain regressions. The author presumes this could be due to measurement error in the simulated tax rate proxies as they do not incorporate the effects of implicit taxes on tax-favoured assets.

Graham (1996a) examines the association between corporate debt policy and tax status. To this end, the author adopts Shevlin (1987)'s approach to simulating marginal tax rates and extends it by additionally incorporating the effects of investment tax credits and the alternative minimum tax in the U.S. Graham (1996a, pp. 42 sq.) assumes his simulated marginal tax rates to be endogenous to corporate financing decisions when using the debt-to-equity ratio as dependent variable. To mitigate the endogeneity concerns, he regresses the first difference in the book value of long-term debt on the one-period lag of the simulated marginal tax rate. Although the author identifies a statistically significant positive impact of the simulated marginal tax rates on incremental debt financing, the results also reveal that the decision to rise debt is primarily driven by the statutory tax rate. Graham (1996a, pp. 69 sq.) finds it surprising that his regression including the simulated marginal tax rate to proxy for tax status yields an adjusted $R^{2}$ that is only 14.7 percent higher than a benchmark regression without any tax variables. Furthermore, he replaces the simulated marginal tax rate with a binary indicator that is one if the company has

2 Deferred taxes are recognised in financial reporting statements to account for temporary differences between financial and tax accounting that will reverse in future years and then give rise to tax rebates or tax liabilities. A positive change in the deferred tax account indicates that current year's taxable income is smaller than reported income. 
a net operating loss carry-forward and zero otherwise, resulting in an increase in the adjusted $R^{2}$ of no less than 7.6 percent compared to the benchmark regression. Against this background, he concludes that "simulating tax rates appears to offer the most refined measure of corporate tax status, although the NOL dummy variable also provides a reasonable proxy" (Graham, 1996a, p. 71).

The study by Graham, Lemmon \& Schallheim (1998) represents an important contribution to the empirical literature on capital structure choice since it offers a solution to the endogeneity problem arising in prior studies where cumulative measures of corporate debt policy (such as debt levels or debt/equity ratios) are used as dependent variables. The authors base the simulation procedure from Equation D.1 on the taxable income before-financing rather than on taxable income after deductions for interest expenses. This allows them to simulate marginal tax rates that are unaffected by companies' past financing choices and, therefore, not endogenous to financing decisions. The authors find support for the proposition that debt usage is positively related to the marginal tax rate to a statistically significant extent. Moreover, a comparison of regression results from alternatively using the post-financing simulated marginal tax rate, the pre-financing simulated marginal tax rate, and a simple NOL dummy variable reveals that only the first variable enters the regression with the predicted positive sign. On the other hand, both other proxies are estimated to be negatively related to debt usage to a statistically significant degree.

In addition, the financing decisions of European companies were studied using simulated marginal tax rates. Alworth \& Arachi (2001) focus on incremental debt financing of large Italian manufacturing companies. They apply a random walk simulation on accounting data from consolidated financial statements and apply federal and local income tax provisions to the simulated income. These provisions differ in respect of tax rates and tax loss offset. The authors use two approaches to prevent endogeneity bias. The first is to lag the simulated marginal tax rates by one year, while the second is to simulate pre-financing marginal tax rates as proposed by Graham, Lemmon \& Schallheim (1998). In either case, they find a statistically significant and positive association between incremental debt financing and the marginal tax rate. HartmannWendels, Stein \& Stöter (2012) analyse the cumulative and incremental financing decisions of German companies. Using a random walk process to simulate pre-financing marginal tax rates, they find a highly statistically significant positive association between the debt/book assets ratio and the marginal tax rate. When adding company-fixed effects, however, the marginal tax rate 
enters the regression with negative sign, with the coefficient being statistically significant at the ten percent level. In their incremental financing analysis, the authors again consistently estimate a positive effect for the one-year-lagged post-financing marginal tax rate with high statistical significance.

Arachi \& Biagi (2005) were, to the best of my knowledge, the first in using simulated marginal tax rates to analyse corporate investment behaviour. Using data on Italian manufacturing companies, the authors define company-specific investment rates and regress them on three various proxies of corporate tax status. In addition to simulated marginal tax rates derived from a random walk process that epitomise the federal and local income tax rates as well as their different tax loss treatment, the authors use the statutory tax rate and a dichotomous tax status proxy that is zero for companies reporting losses and equals the statutory tax rate for profitable companies in their regressions. Estimating a dynamic investment model results in all three proxies entering the regression equation with almost identical coefficients and p-values. From this, the authors infer that a thorough measurement of tax status cannot significantly improve the statistical performance of their econometric model. Ramb (2007) examines the investment behaviour of German companies. The author develops two different empirical estimation models, one being derived from an autoregressive distributed lag model, and the second from an error correction model. He regresses the investment/lagged capital stock ratio on marginal tax rates that are simulated by means of a random walk model and reflect the effects of German tax loss treatment. Although estimated to be economically small, the short-term investment effect of the simulated tax rate turns out to be statistically significant in both empirical specifications. As to long-term investment effects, however, the simulated marginal tax rate shows statistical significance only in the econometric specification of the autoregressive distributed lag model. Edgerton (2010) investigates how companies' tax statuses impact on their reaction to bonus depreciation tax incentives. His findings suggest that tax asymmetries caused a four percent smaller response to the investment incentive as compared to a hypothetical case were all companies would have been fully taxable. He controls for tax status using four different proxies: a nontaxable dummy that is one for companies that neither pay taxes in a given year nor receive carrybacks, and zero otherwise; the Plesko (2003) dichotomous variable that is one for companies having both negative taxable income and a loss carryforward from prior years, and zero otherwise; the Plesko (2003) trichotomous variable that is one for companies with both negative taxable income and a loss carryforward from prior years, but is 0.5 if only one of the two conditions is met, and zero 
otherwise; and finally a slightly recoded random walk simulation-based marginal tax rate measure, defined as $1-$ (simulated marginal tax rate/statutory tax rate). The explanatory power, measured by $R^{2}$, varies only slightly across the different specifications, thus substantiating the assumption that a careful modelling of tax asymmetries does not improve empirical identification of tax incentives.

\subsection{Non-parametric bin approach}

While adhering to the general definition and computation of the marginal tax rate as representing the present value of current and expected future taxes triggered by earning an additional unit of taxable income in the current year, Blouin, Core \& Guay (2010) raise concerns about using a random walk approach to simulate future taxable income. They argue that the random walk approach introduces error and bias into the projected income stream, as it does not account for the empirically observable mean reversion in income and is likely to substantially understate future income volatility (Blouin, Core \& Guay, 2010, p. 196). The authors contribute to the literature by developing a simulation procedure that does not employ the company-specific income distribution moments mean and volatility for the simulation. Instead, they assume that the development of companies of similar profitability and size in the past is the best predictor for the future development of any company. Specifically, the assumption is that companies' managers form expectations about their marginal tax rate in year $t+1$ based on information about their own current-year taxable income in $t$ and about the development of peer-group companies from $t-2$ until $t-1$. A third core feature of the Blouin, Core \& Guay (2010) approach is that taxable income scaled by total assets is simulated rather than absolute levels of taxable income.

Forecasting taxable income according to this approach, firstly, necessitates the clustering of all companies with available data into six 'bins' of companies with similar profitability in $t-2$, with the subset of negative-ROA companies being ranked into two bins and the subset of positiveROA companies being ranked into four bins. Profitability is measured by a taxable return on average total assets ratio

$$
R O A_{i, t}=T I_{i, t} / T A_{i, t}
$$

where $T I_{i, t}$ denotes taxable income before transitory items and loss-offset of company $i$ in year $t$ according to the Graham $\left(2000\right.$, p. 1938) definition and $T A_{i, t}=\left(T A_{i, 1 / 1 / t}+T A_{i, 31 / 12 / t}\right) / 2$ is 
average total assets of company $i$ in year $t$. Then, each of the six bins is further partitioned into five sub-bins according to quintiles of total assets in $t-2$. Having assigned all companies to one of the 30 performance-size bins, for each company $i$ the first difference in ROA

$$
\Delta R O A_{i, t-1}=R O A_{i, t-1}-R O A_{i, t-2}
$$

and the growth in average total assets

$$
G T A_{i, t-1}=T A_{i, t-1} / T A_{i, t-2}
$$

is calculated. In the second step, a matching procedure is applied: for company $i$ the authors examine which $t-2$ bin it would be classified in based on its ROA and average total assets in year $t$, and a benchmark company $j \neq i$ is randomly drawn from the respective bin. In the third step, the benchmark company's $\Delta R O A_{j, t-1}$ and $G T A_{j, t-1}$ are used to predict taxable income of company $i$ in year $t$ as follows:

$$
\begin{aligned}
& R O A_{i, t}=R O A_{i, t-1}+\Delta R O A_{j, t-1} \\
& T A_{i, t}=T A_{i, t-1} \times G T A_{j, t-1} \\
& T I_{i, t}=R O A_{i, t} \times T A_{i, t}
\end{aligned}
$$

To estimate subsequent years' taxable incomes $\left(T I_{i, t+1}, \ldots, T I_{i, T-1}, T I_{i, T}\right)$ the procedure is repeated subject to annual re-examination of the assignment to performance-size bins and also the benchmark company is annually redrawn.

Using data on the income stream as actually realised, Blouin, Core \& Guay (2010, pp. 202 sqq.) show that, especially for companies with relatively low or high ROA performance, their bin approach predicts future taxable income more accurately than the random walk approach. To evaluate how forecast accuracy impacts on the distribution of resultant marginal tax rates, the authors estimate pre-financing marginal tax rates according to both the bin and the Graham (1996b) method. Over the whole sample, they find the mean values of the marginal tax rates to be almost equal, with the bin approach yielding a somewhat smaller number of companies with very low marginal tax rates than the random walk approach. On closer inspection, the random walk-based marginal tax rates of unprofitable companies turn out to be up to five percent smaller on average than those obtained by the bin method. Considering highly profitable companies, the random walk simulation results in marginal tax rates that are up to 1.8 percent higher on average than the bin approach-based marginal tax rates. From further analyses, Blouin, Core \& 
Guay (2010, pp. 204 sqq.) infer that, due to the utilisation of the random walk approach, Graham (2000) overestimates the share of companies that have not yet fully exploited the potential for tax benefits by raising more debt.

\subsection{First-order autoregressive approach}

Graham \& Kim (2009, pp. 7 sq.) point to three features that an effective approach to simulating taxable income should offer. Firstly, the approach should account for the empirical observation that annual accounting income and profitability are often mean-reverting due to transitory income components. Related to this issue, the simulation should, secondly, be based on company-specific information as companies are expected to differ in how quickly mean reversion sets in and how volatile income is. Thirdly, scaled income rather than absolute levels of income should be simulated in order to avoid the income volatility being understated. In essence, the bin approach proposed by Blouin, Core \& Guay (2010) is not based on purely company-specific data. Therefore, Graham \& $\operatorname{Kim}(2009$, p. 2) expect the bin approach to lead to inaccurate estimates of the tax status for companies that are, in terms of profitability, too different from the average company in the respective bin. To merge the three features into one approach, Graham \& Kim (2009, p. 11) suggest using an autoregressive model of order one to simulate scaled taxable income:

$$
R O A_{i, t}=\mu_{i}+\rho_{i} \times R O A_{i, t-1}+\epsilon_{i, t}, \quad \epsilon_{i, t} \stackrel{i i d}{\sim} \mathcal{N}\left(0, \sigma_{i}\right)
$$

In Equation D.8, $R O A_{i, t-1}=T I_{i, t-1} / T A_{i, t-2}$ denotes scaled taxable income, being measured as the ratio of taxable income before transitory items and loss-offset, as defined in Blouin, Core \& Guay (2010, p. 211) and Graham (2000, p. 1938), to beginning-year total assets. The drift parameter $\mu_{i}$, the first-order autoregressive parameter $\rho_{i}$ and the standard deviation of residuals $\sigma_{i}$ are obtained from company-specific ordinary least square regressions of Equation D.8 using rolling time-series of historical company data.

This ensures that the resultant $\operatorname{AR}(1)$ parameters capture company-specific states of "cyclicality' and 'riskiness', as demanded by Graham \& Kim (2009, pp. 7 sq.). To avoid bias in the projected future taxable income stream and the related marginal tax rate, a sufficient number of historical company-year observations must be available and the assumption of statistical stationarity of company income must hold. Graham \& Kim (2009, p. 12) consider the obtained 
$\mathrm{AR}(1)$ parameters to be unsuitable in this respect if one or more of the following criteria is met:

- The estimated company-specific process is non-stationary, as indicated by $\left|\rho_{i}\right| \geq 1$.

- The estimated volatility in scaled taxable income appears to be unusually high, as indicated by $\sigma_{i}>1$.

- The estimated long-run mean of scaled taxable income appears to be too large in absolute terms, as indicated by $\left|\frac{\mu_{i}}{1-\rho_{i}}\right|>0.6$

- The number of historical company-year observations is smaller than four.

In this case, the company-specific parameter estimates are replaced by peer group-specific parameter estimates derived from separately performed regressions instead. To this end, in a manner comparable to that in Blouin, Core \& Guay (2010), Graham \& Kim (2009, p. 12) rank, company-year observations into six income groups (two groups for negative and four groups for positive ROA observations) which are further subdivided by industry. Then, the authors re-estimate the parameters in Equation D. 8 for each of these subgroups by means of the system GMM estimator developed by Blundell \& Bond (1998) and substitute the resultant peer groupspecific parameter estimates for the unsuited company-specific parameter estimates.

In addition to forecasting scaled taxable income, it is necessary also to project the continuing amount of total assets in future years. For this, Graham \& Kim (2009, p. 33) use the cleansurplus accounting approach:

$$
T A_{i, t}=T A_{i, t-1}+T I_{i, t} \times\left(1-\tau_{i, t}\right)-D_{i, t}
$$

where $\tau_{i, t}$ is the top statutory corporate income tax rate in year $t$ and $D_{i, t}$ is a company $i$-specific estimate for the amount of profits distributed to its shareholders in year $t$. Profit distributions $D_{i, t}$ are obtained by multiplying a company-specific dividend pay-out ratio by forecasted taxable income according to the following piecewise-defined function:

$$
D_{i, t}= \begin{cases}\min \left(1, \max \left(0, \frac{D_{i, t-1}}{T I_{i, t-1} \times\left(1-\tau_{i, t-1}\right)} \times T I_{i, t}\right)\right) & \text { if } \quad T I_{i, t}>0 \wedge T I_{i, t-1} \geq 0 \\ \min \left(1, \max \left(0, \frac{D_{i, t-1}}{0.06 \times T A_{i, t-2}} \times T I_{i, t}\right)\right) & \text { if } \quad T I_{i, t}>0 \wedge T I_{i, t-1}<0 \\ D_{i, t-1} & \text { if } \quad T I_{i, t} \leq 0\end{cases}
$$

Finally, the forecasted values of non-scaled taxable income (before tax loss carry-over) are obtained by multiplying simulated scaled taxable income and projected beginning-year total assets: 


$$
T I_{i, t}=R O A_{i, t} \times T A_{i, t-1}
$$

Graham \& Kim (2009, pp. 18 sqq.) contrast their approach with the random walk and the bin approach in order to find out which one yields the best point estimates of the marginal tax rate on a company-by-company basis, and which most accurately predicts the distribution of marginal tax rates across all companies in the sample. They determine the $\mathrm{AR}(1)$-simulation approach as best performer. The authors then proceed to compare the marginal tax benefit functions implied by the different simulation methods. Results for a sub-sample of companies with low marginal tax rates reveal that the bin method-related benefit curve suggests the marginal tax benefit from deducting one more dollar of interest to be some two to three percentage points higher than the AR(1) and benchmark benefit curves. Graham \& Kim (2009, p. 26) further inspect what conclusions regarding debt conservatism can be drawn from the simulation methoddependent marginal tax benefit curves. They find that the bin approach implies a tax benefit curve according to which the marginal tax benefits of incremental debt financing begin to decline much earlier than indicated by the benefit curves resulting from a random walk, $\operatorname{AR}(1)$ or benchmark-perfect foresight model. Graham \& Kim (2009, p. 28) thus argue that Blouin, Core \& Guay (2010)'s conclusion of companies to use debt too conservatively hinges on their use of the bin method to simulate marginal tax rates and their specification of the threshold value that governs how steep the first decline in the tax benefit curve from one interest increment to the next must be in order for the benefit curve to be considered as downward sloping.

\section{Discussion of selected aspects regarding the determination of simulated marginal tax rates}

\subsection{Approach to simulating future income}

The literature review reveals that simulated marginal tax rates have thus far proved to perform unequally well in econometric models of corporate financing and investment behaviour. As to capital structure research, extant evidence is consistent in showing a statistically significant positive association between both incremental and cumulative financing decisions of companies and the simulated marginal tax rate, though the estimated tax effects are often viewed as being unexpectedly low (Devereux, Maffini \& Xing, 2015, p. 1). Even smaller effects were identified by researchers who used the simulation approach to study tax effects on corporate investment. 
Finally, the use of simulated marginal tax rates was often not accompanied by an increase in empirical models' explanatory power.

In light of the insights from Blouin, Core \& Guay (2010) and Graham \& Kim (2009), the random walk assumption of future taxable income development may be responsible for these findings. A more thorough investigation on that point is made by Koch (2014b) who uses econometric diagnostics to test the forecasting performance of the three models. ${ }^{3}$ He contrasts the income stream actually realised with the projections obtained by a random walk, $\operatorname{AR}(1)$ and bin approach. Koch (2014b, pp. 151 sqq.)'s results indicate that simulating taxable income by means of an $\mathrm{AR}(1)$ model results in marginal tax rates that are less affected by measurement error in future income than those resulting from a random walk model or the bin approach. His empirical analysis of incremental financing decisions based on a multivariate setting reveals that the R-squared is highest when using bin approach-based marginal tax rates, whilst AR(1)-based marginal tax rates increase the explanatory power of the model most significantly, compared to a benchmark case where tax status is proxied by the statutory tax rate (Koch, 2014b, pp. 157 sqq.). Yet considering how closely the differently simulated marginal tax rates reflect actual companyspecific tax incentives to finance with debt, Koch (2014b, p. 159) concludes that "the choice of the simulation approach seems (...) not to be a key driver for improving the identification of tax-related debt policy".

In summing up all empirical evidence, the AR(1) model appears to be an appropriate choice of simulation approach. It has proved to forecast future income with a higher precision relative to the other approaches, especially on the individual company level (Graham \& Kim, 2009, p. 21; Koch, 2014b, p. 152). While appreciating this feature, Blouin, Core \& Guay (2010, p. 201) make the qualification that the $\mathrm{AR}(1)$ approach tends to underestimate the volatility of taxable income. However, Koch (2014b, p. 152) shows that the same may well hold true for the bin method. As noted above, the AR(1) approach has, in addition, the advantages of being able to deal with company-specific data, model scaled income and allow for mean reversion in scaled income. On the negative side, the approach is very demanding in terms of data requirements. To appropriately estimate the simulation parameters from Equation D.8, a minimum of four consecutive historic company-year observations is needed. If data coverage is poor, this prerequisite is likely to cause a substantial decrease in sample sizes.

3 Koch (2014b) uses financial statement data on EU corporations from the AmAdeus database. As the data do not disclose information about deferred taxes in isolation, he chooses to forecast pre-financing taxable income instead. 


\subsection{Use of consolidated financial statement data}

Accurate inferences on corporate responses to tax effects require that corporate tax status is precisely measured. Original tax return data are preferable in this regard as they allow for identification of actual tax positions and, thus, companies' actual tax incentives (Graham \& Mills, 2008, p. 367; Devereux, Maffini \& Xing, 2015, p. 21). In principle, however, tax return data are confidential and usually not accessible. Therefore, it is common to derive proxies for corporate tax status from financial statement data instead. Fortunately, financial statement data are found to be well suited as a basis for simulating marginal tax rates. For a matched sample of financial accounting and tax return information on U.S. companies, Plesko (2003, p. 221) shows that their true marginal tax rate, calculated from tax return data, is strongly positively correlated ( $\rho=0.907)$ with the simulated marginal tax rate obtained by the Graham, 1996a method. This result is confirmed by Graham \& Mills (2008, pp. 378 sqq.). Evidence is mixed, however, for the relative suitability of simulated book marginal tax rates versus actual tax return marginal tax rates to explain capital structure tax incentives empirically. Using data on U.S. companies, Graham \& Mills (2008, pp. 384 sqq.) find that the former perform better. By contrast, Devereux, Maffini \& Xing (2015, pp. 20 sqq.) receive larger and more statistically significant coefficient estimates when using tax return marginal tax rates rather than book simulated marginal tax rates to proxy UK companies' capital structure tax incentives. From this, they conclude that tax effects identified in previous studies using book simulated marginal tax rates are likely to suffer from attenuation bias.

While recognising that book simulated marginal tax rates are generally able to approximate a company's true marginal tax rate appropriately, it appears doubtful that the U.S. way of basing simulation on consolidated financial statement data can be considered a suitable alternative for the European case, too. Plesko (2003, p. 204) and Graham \& Mills (2008, p. 372) point out that a potential source of error in the measurement of corporate tax status could emerge from differences in the consolidation scope for financial accounting and tax purposes, because then tax incentives are possibly not measured for the entity under scrutiny. While Graham \& Mills (2008, p. 369) expect simulated marginal tax rates based on consolidated book income to generally perform better than tax return based measures to capture companies' tax incentives related to worldwide activities, Koch (2014b, p. 161) discusses potential sources of measurement error that are likely to bias simulated marginal tax rates based on consolidated data. Firstly, if tax law restricts the scope for intra-group loss compensation, if available at all, to the domestic 
part of the group and prohibits foreign losses to be netted against domestic profits (as is the case both in the U.S. and most European countries, except for Austria, Denmark, France and Italy), the beneficial impact of intra-group loss compensation can be expected to be overstated in the simulation. Secondly, lacking information about the geographical breakdown of consolidated income, researchers were forced to implicitly assume that the consolidated income is taxed at the parent company's tax rate, irrespective of its actual origin. Koch (2014b) finds this limitation of consolidated financial statement data to represent an even more significant source of measurement error if repatriated foreign source income is actually tax-exempt at the parent level. Given that most European countries apply the exemption method to avoid double taxation of intercompany dividends (Endres \& Spengel, 2015, p. 120), using consolidated financial statement data for simulating marginal tax rates of European companies appears inappropriate.

\subsection{Determination of taxable income}

Studies from the U.S. usually employ financial statement data from the COMPUSTAT database which makes available accounting data in a disaggregate and standardised format. In particular, it reports in isolation detailed information about deferred taxes. Researchers (e.g. Shevlin, 1987, p. 493; Shevlin, 1990, p. 58; Graham, 1996a, p. 47; Graham \& Mills, 2008, pp. 371 sq.; Blouin, Core \& Guay, 2010, p. 211) infer from the change in the deferred tax account an estimate of taxable income by applying the following formula:

$$
T I_{t}=P T B I_{t}-\frac{\Delta D T_{t}}{\tau}
$$

In Equation D.12, $T I_{t}$ denotes estimated taxable income in year $t, P T B I_{t}$ denotes reported pre-tax book income in year $t, \Delta D T_{t}$ is the annual change in the deferred tax account from year $t-1$ to year $t$ and $\tau$ is the statutory marginal tax rate.

This approach may be appropriate to estimate taxable income if book income is reported on a unconsolidated basis and any existing differences between book and tax income are temporary. But if income is reported on a consolidated basis and (partially) foreign sourced, then using the parent level tax rate will lead to erroneous results (Hanlon, 2003, p. 844). In addition, taxable income will be estimated the less precise by Equation D.12 the more relevant permanent book-tax differences are (Graham \& Mills, 2008, p. 369). Hanlon \& Heitzman (2010, pp. 169 sq.) expect permanent differences to occur less frequently than temporary differences. This assessment is 
based on U.S. considerations. Consolidated income does basically include the income of all majority-owned domestic and foreign subsidiaries, net of intragroup results. Whereas in most European countries repatriated dividend income is tax-exempt at the parent company level, in the U.S. the credit method is applied. Under the credit method, the U.S. parent must include received gross dividends into the tax base but may in return deduct the resultant tax liability from the foreign income taxes paid on the dividends. As the U.S. tax rate is in most cases higher than the source countries' tax rates on dividends, the credit method results frequently in a residual U.S. tax due on repatriated dividends. U.S. accounting rules require U.S. parent companies to recognise a deferred tax liability for these future tax liabilities in their consolidated statements. As repatriated income should account for a large share of overall group income, I expect permanent differences to be relatively more relevant in Europe than in the U.S., making the adjustment method for deferred taxes less suitable in the European context.

Independently of these potential limitations, determining marginal tax rates from forecasts of so-obtained estimates of taxable income must be considered as improper from a conceptual point of view. To see this, consider a simple example. Assume a company that reports in its current-year financial statement a book profit before taxation of $P T B I_{t-1}=€ 500$ that equals - absent the need for tax adjustments - the taxable income before loss offset. At the prior-year end, the company has a tax loss carry-forward of $L C F_{t-2}=€ 1,000$ and thus reports in the financial statement a deferred tax asset of $D T_{t-2}=€ 150$ (a statutory marginal tax rate of $\tau=15 \%$ is assumed). Provided that loss carryforward restrictions do not apply, the tax authorities will calculate the company's current year taxable income as $T I_{t-1}=$ $P T B I_{t-1}-\min \left(L C F_{t-2}, P T B I_{t-1}\right)=€ 500-\min (€ 1,000, € 500)=€ 0$. Inserting disclosed information on deferred taxes into Equation D.12 yields: $T I_{t-1}=P T B I_{t-1}-\left(\Delta D T_{t-1} / \tau\right)=$ $€ 500-(€ 75 / 0.15)=€ 0$. As the book-tax difference in the example is solely due to temporary differences from tax loss carry-forwards, Equation D.12 gives the correct result for the company's taxable income, but - and this is essential - after tax loss offset. Consequently, there is neither a need nor a justification to perform additional coding of tax loss offset rules to the simulated stream of taxable income. However, this is often overlooked in prior research. 


\section{Simulating marginal tax rates of European companies}

\subsection{General considerations}

Acknowledging that original tax return data should be the first best source for identifying companies' real tax incentives, the deferred tax adjustment method is an attempt to synthesise tax return-quality figures from financial statement data. However, the previous discussion has revealed that this approach has certain weaknesses in its ability to determine taxable income and is associated with methodological inaccuracies regarding the modelling of inter-period tax loss offset. By contrast, similar research on European companies' behaviour does typically apply tax loss carry-over provisions directly on book income. In the absence of further efforts to approximate taxable income, the resultant marginal tax rates could potentially also suffer from measurement inaccuracies, in particular if certain tax rules are disregarded although they are in fact relevant to managers.

As already stated in the preceding section, the tax exemption of dividend income that is of widely used across Europe constitutes an important source of permanent differences between financial accounting income and taxable income. If such differences are not taken into consideration in the determination of taxable income then the base for inter-period tax loss offset may well be estimated unreasonably high, potentially resulting in an understatement of the effects of tax loss carry-over provisions.

When studying the tax incentives of affiliated companies, it may be inappropriate to implicitly assume those companies to be taxed on a stand-alone basis. In many countries group taxation regimes exist that grant resident companies extended opportunities to offset losses if they are controlled by a common parent. Generally speaking, those provisions allow the possibility of pooling all profits and losses and taxing them at the level of the parent. Thereby, a loss offset between companies is achieved. A mapping of these tax consequences in the simulation procedure should increase the ability of simulated marginal tax rates to capture tax incentives related to business decisions within groups of companies. This should constitute a valuable contribution to the literature for two reasons. Firstly, existing studies model incentives to shift tax bases to low-tax countries not by means of marginal tax rates but use statutory tax rates (e.g. Grubert \& Mutti, 1991), GAAP effective tax rates (e.g. Klassen, Lang \& Wolfson, 1993), statutory tax rate differentials between the countries in which the individual companies of the group are situated (e.g. Collins, Kemsley \& Lang, 1998) or mixtures of those approaches (e.g. Klassen \& Laplante, 
2012) instead. By taking into account specific tax regulations, simulated marginal tax rates allow for a more precise differentiation between the tax positions of affiliated companies located in the same country. Secondly, due to the fact that statutory or GAAP effective tax rates are unsuited to appropriately capture tax incentives related to loss-making companies, these companies are commonly excluded in previous work in order to avoid potentially biased estimates of the tax rate elasticity (e.g. Huizinga \& Laeven, 2008, Dharmapala \& Riedel, 2013). In this respect, simulated marginal tax rates provide a means to consistently measure tax incentives for both profitable and loss-making companies.

As with profits and losses, tax laws treat equity and debt capital in an asymmetrical manner. While dividend payments do not reduce the tax base of the distributing company, interest payments are generally deductible from the borrowing company's tax base. As long as a company is fully taxable, each unit of interest paid results in a tax saving equal to the company's marginal tax rate. Extant research on capital structure choice was quite successful in showing that the incentive to substitute debt for equity capital is lowered if tax loss carry-forwards are present. This is because (sufficiently large) loss carry-forwards shield the company from taxation and, thus, impede the company from realising debt-related tax savings. In those studies it is generally overlooked that many countries provide for anti-abuse legislation that is targeted towards preventing companies from excessive debt financing. According to the relevant rules, the amount of tax deductible interest on debt from related or possibly also unrelated parties may be limited or fully denied if the leverage ratio or the interest expenses of a company exceed allowable limits. A company that is legally classified as being excessively financed with debt can no longer realise tax benefits from interest deductions even if it does not have a tax loss carry-forward. Incorporating these sources of tax exhaustion into the marginal tax rate calculations should increase the measurement precision of simulated marginal tax rates. Suchlike refined measures of corporate tax status might be more able to explain the incentives of stand-alone companies to using debt rather than equity as well as the incentives of multinationals to shift tax bases across jurisdictions through internal debt.

Notional interest deduction rules represent an alternative means to reduce the tax attractiveness of debt relative to that of equity financing. These rules have the potential to significantly reduce a company's tax burden by allowing companies to deduct an imputed interest on equity capital from their tax bases. The deductible amount is computed by multiplying an adjusted equity variable with a legally defined interest rate. Since the amount granted for deduction is 
generally only determined by the value of equity capital, notional interest deduction rules are beneficial especially for those companies with relatively low profitability but relatively high equity capital (Endres \& Spengel, 2015, p. 88). Considering the specific case of Belgium, Kestens, Cauwenberge \& Christiaens, 2012 find that the introduction of the notional interest deduction caused a sharp decline in the effective tax rates of small and medium-sized enterprises.

A detailed description how these tax rules are modelled for reconciliation of book income to taxable income is given in the following sections. In respect thereof, an important econometric point must be made beforehand. In order to be able to code the tax exemption of received dividends and the deductibility restrictions on interest payments, it is necessary to simulate a measure of income in which these components are included. In fact, the respective tax adjustments cannot be carried out on a simulated before-financing measure of income, as then the relevant connecting factors would not be available. For that reason, I will simulate after-financing book income, being however aware that after-financing marginal tax rates are generally endogenous to financial leverage decisions. Consequently, the scope of application of the resultant marginal tax rates in the field of capital structure research is restricted to studies on incremental financing decisions (Graham, 1996a, p. 54).

\subsection{Data collection and simulation procedure}

\subsubsection{Sample selection}

I draw accounting data from the commercial database AmADEus published by Bureau van Dijk. Currently, Amadeus contains standardised financial statement and ownership information about approximately 21 million companies across Europe. The database updates 125 (February 2005), 172 (January 2009) and 250 (October 2014) provide unconsolidated accounts for financial years between 1994 and 2013. Before using these informations, the raw data are corrected for various types of inconsistencies, as described by Oestreicher, Koch, et al., 2013, pp. 33-41.

The starting sample is comprised of 5,764,721 firms that are resident in Member States of the EU 27. In a first step, I restrict the sample to entities that are subject to corporate income tax in their countries of residence by excluding 321,517 firms with legal forms that are not covered by Council Directive 2003/123/EC. A further 4,683,756 firms are independent firms. As in the course of this paper particular interest shall be attributed to groups of companies, I exclude in a second step all these stand-alone firms. Unlike financial statement data, ownership data are 
Table D.1: Data collection process summarised by country

\begin{tabular}{|c|c|c|c|c|}
\hline Country & Initial sample & $\begin{array}{l}\text { Not subject to cor- } \\
\text { porate income tax }\end{array}$ & Independent firms & Final sample \\
\hline Austria & 7,039 & -596 & $-2,207$ & 4,236 \\
\hline Belgium & 74,727 & $-5,254$ & $-49,006$ & 20,467 \\
\hline Bulgaria & 280,616 & $-27,435$ & $-226,294$ & 26,887 \\
\hline Cyprus & 535 & -11 & -448 & 76 \\
\hline Czech Republic & 174,775 & $-2,941$ & $-143,484$ & 28,350 \\
\hline Denmark & 27,199 & $-2,025$ & $-15,106$ & 10,068 \\
\hline Estonia & 97,118 & 0 & $-86,129$ & 10,989 \\
\hline Finland & 172,946 & -659 & $-152,506$ & 19,781 \\
\hline France & 816,628 & $-200,437$ & $-533,690$ & 82,501 \\
\hline Germany & 76,183 & $-18,688$ & $-31,946$ & 25,549 \\
\hline Greece & 28,472 & -117 & $-25,019$ & 3,336 \\
\hline Hungary & 367,391 & $-1,248$ & $-352,652$ & 13,491 \\
\hline Ireland & 17,837 & $-1,025$ & $-12,752$ & 4,060 \\
\hline Italy & 932,293 & $-3,489$ & $-784,106$ & 144,698 \\
\hline Latvia & 106,033 & $-4,905$ & $-91,411$ & 9,717 \\
\hline Lithuania & 4,475 & -103 & $-3,690$ & 682 \\
\hline Luxembourg & 9,023 & -234 & $-4,509$ & 4,280 \\
\hline Malta & 13,926 & -373 & $-8,607$ & 4,946 \\
\hline Netherlands & 12,925 & -103 & $-5,969$ & 6,853 \\
\hline Poland & 116,934 & $-25,044$ & $-66,359$ & 25,531 \\
\hline Portugal & 312,483 & $-1,171$ & $-286,390$ & 24,922 \\
\hline Romania & 606,936 & $-4,776$ & $-579,916$ & 22,244 \\
\hline Slovakia & 152,645 & $-1,270$ & $-137,200$ & 14,175 \\
\hline Slovenia & 54,343 & $-6,652$ & $-44,665$ & 3,026 \\
\hline Spain & 731,625 & $-3,942$ & $-654,107$ & 73,576 \\
\hline Sweden & 375,178 & 0 & $-263,960$ & 111,218 \\
\hline United Kingdom & 194,436 & $-9,019$ & $-121,628$ & 63,789 \\
\hline Total & $5,764,721$ & $-321,517$ & $-4,683,756$ & 759,448 \\
\hline
\end{tabular}

Source: Own calculations.

not available on an annual basis but do only indicate the composition of corporate groups at the times of update publications. Since the Bureau van Dijk company identifiers have been revised on a number of occasions during the period under study, I am not able to associate the firms from the 2014 update with ownership data from the preceding updates. Therefore, I am reliant on the assumption that the most recent information on corporate group structures is also valid from 2003 onwards. After removing all firms that are classified as being independent based on update 250 , the final sample consists of 759,448 companies. Table D.1 provides country-level information about the data collection process.

\subsubsection{Parameter estimation}

In order to calculate the company-specific marginal tax rate in year $t$ by means of the $\mathrm{AR}(1)$ model proposed by Graham \& Kim, 2009, a multi-step process needs to be executed. The simulation procedure is visualised in Figure D.1. At the very beginning, I estimate various parameters from historical accounting data that are subsequently used to forecast future book 
Figure D.1: Simulation of pre-tax book income

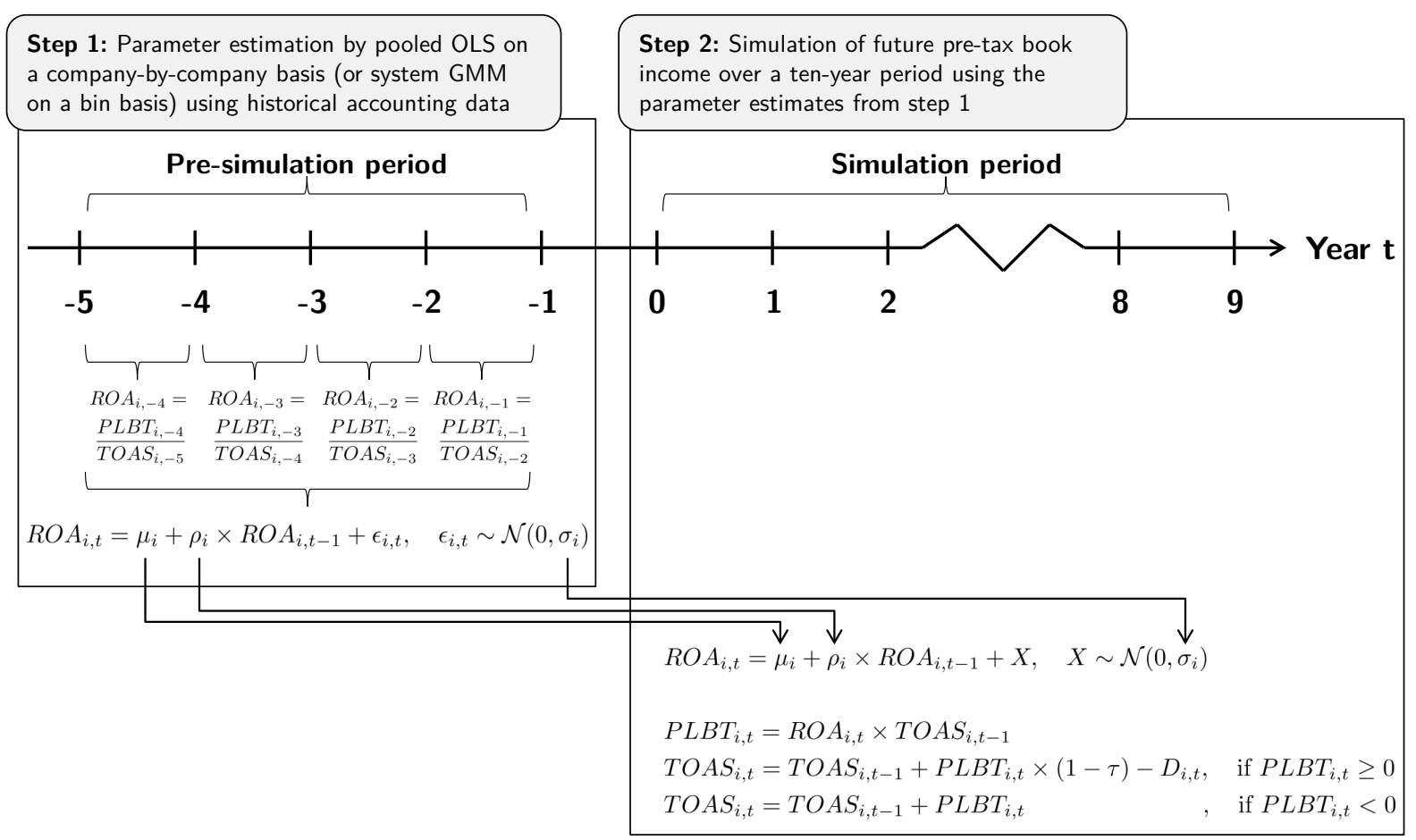

Source: Own figure.

income streams. Using financial statement information on the pre-tax book income before extraordinary items (AMADEus item 'P/L before Tax', denoted by PLBT) and the beginningyear balance sheet total (AmADEus item 'Total Assets', denoted by TOAS) of each company over the pre-simulation period $t=[-5,-1]$, I compute for $t=[-4,-1]$ the realised scaled income $R O A_{i, t}=P L B T_{i, t} / T O A S_{i, t-1}$. If there are less than four historical observations available for a company-year, the respective company-year is dropped from the sample (Graham \& Kim, 2009, p. 12). To avoid that outliers or erroneous observations have adverse effects on the simulation outcome, I exclude all company-years with an $\left|R O A_{i, t}\right|>2$ (Graham \& Kim, 2009, p. 11) or a balance sheet total of less than $€ 1$ million (Graham \& Kim, 2009, p. 15) from the sample.

Table D.2 presents a country-wise composition of the resultant subsamples for each individual simulation year during 2003 and 2013. As with Graham \& Kim, 2009, the requirement of a sufficiently large accounting data history allows marginal tax rates to be simulated for only a small portion of companies contained in the selected starting sample. Since the coverage of balance sheet and profit and loss statement data in AMADEus has increased over time, the simulation samples are larger for more recent years. Anyhow, the 2013 sample still comprehends only 121,830 companies, which corresponds to a share of some 16 percent in the starting sample. 
But the relative number of observations being lost varies strongly across countries. While there are still 1,655 out of initially 3,336 Greek companies (49.61\%) included in the sample, there are only 20 out of initially 10,068 Danish companies (0.2\%) for which Amadeus provides sufficient accounting data to simulate marginal tax rates.

Equation D.8 is estimated on a company-by-company basis by ordinary least squares regression on the pooled time-series financial statement data. As a result, I receive the drift parameter $\mu_{i}$, the autoregressive parameter $\rho_{i}$, the value of the white noise process $\epsilon_{i, t}$ and its standard deviation $\sigma_{i}$. In line with Graham \& Kim, 2009, p. 12, I then form groups of companies that have similar financial performance ${ }^{4}$ and belong to the same industry sector ${ }^{5}$. These groups are formed country-wise. Afterwards, I re-estimate Equation D.8 separately for each bin by using the system GMM estimator developed by Blundell \& Bond, 1998 and substitute the resultant parameter estimates for the company-specific OLS estimates obtained before if the latter do not fulfill the conditions described in Section 2.3.

\subsubsection{Simulation of pre-tax book income}

The second step is to simulate pre-tax book income $P L B T_{i, t}$ over a ten-year forecasting horizon $t=[0,9]$. To this end, at first scaled pre-tax book income, $R O A_{i, t}$, is simulated under uncertainty using the following formula

$$
R O A_{i, t}=\mu_{i}+\rho_{i} \times R O A_{i, t-1}+x, \quad x \stackrel{i i d}{\sim} \mathcal{N}\left(0, \sigma_{i}\right),
$$

where $x$ is a random variable that is independently and identically distributed with zero mean and standard deviation of the company-specific white noise process $\sigma_{i}$. The so-obtained projections of scaled pre-tax book income are converted to absolute values of pre-tax book income, $P L B T_{i, t}$, by multiplying the simulated $R O A_{i, t}$ with beginning-year updated total assets, $T O A S_{i, t-1}$, derived from the clean-surplus relation in Equation D.9. The balance sheet total at

4 Following Graham \& Kim, 2009, p. 12, I define six income groups. Companies are ranked according to their ROA. Negative ROA companies are subdivided into two equally sized groups, whereas positive ROA companies are assigned to one of the four remaining income groups, according to their rank.

5 I assume companies to belong to the same industry sector if they are assigned the same NACE Rev. 2 main section code in Amadeus 
Table D.2: Composition of simulation panels summarised by country and year

\begin{tabular}{|c|c|c|c|c|c|c|c|c|c|c|c|c|c|c|c|c|c|c|c|c|c|c|}
\hline \multirow[b]{2}{*}{ Country } & \multicolumn{2}{|c|}{2003} & \multicolumn{2}{|c|}{2004} & \multicolumn{2}{|c|}{2005} & \multicolumn{2}{|c|}{2006} & \multicolumn{2}{|c|}{2007} & \multicolumn{2}{|c|}{2008} & \multicolumn{2}{|c|}{2009} & \multicolumn{2}{|c|}{2010} & \multicolumn{2}{|c|}{2011} & \multicolumn{2}{|c|}{2012} & \multicolumn{2}{|c|}{2013} \\
\hline & Obs. & in $\%$ & Obs. & in $\%$ & Obs. & in $\%$ & Obs. & in $\%$ & Obs. & in $\%$ & Obs. & in $\%$ & Obs. & in $\%$ & Obs. & in $\%$ & Obs. & in $\%$ & Obs. & in $\%$ & Obs. & in $\%$ \\
\hline Austria & 0 & 0.00 & 0 & 0.00 & 0 & 0.00 & 0 & 0.00 & 0 & 0.00 & 0 & 0.00 & 191 & 0.22 & 428 & 0.46 & 936 & 0.90 & 1,092 & 0.95 & 1,231 & 1.01 \\
\hline Belgium & 3,584 & 8.79 & 3,869 & 7.75 & 4,137 & 7 & 4,438 & & 760 & 7.70 & 5,057 & 7.44 & 6,807 & 7.83 & 6,760 & 32 & 7,080 & 6.80 &, 484 & 6.51 & 7,847 & 6.46 \\
\hline Bulgaria & 0 & 0.00 & 364 & 0.73 & 436 & 0.84 & 499 & 0.89 & 557 & 0.90 & 651 & 0.96 & 938 & 1.08 & 1,093 & 1.18 & 1,548 & 1.49 & ,920 & 1.67 & 2,159 & 1.78 \\
\hline Cyprus & 0 & 0.00 & 0 & 0.00 & 0 & 0.00 & 0 & 0.00 & 0 & 0.00 & 0 & 0.00 & 0 & 0.00 & 0 & 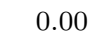 & 0 & 0.00 & 1 & 0.00 & 1 & 0.00 \\
\hline Czech Republic & 498 & 1.22 & 620 & 1.24 & 749 & 1.44 & 1,042 & 1.87 & 384 & 2.24 & 1,761 & 2.59 & 305 & 2.65 & 589 & 0 & 100 & 2.98 & 529 & 3.07 & 619 & 2.98 \\
\hline Den & 0 & & 0 & & 0 & & 0 & & 0 & & 0 & & 0 & 0.00 & 0 & & 0 & & 0 & & 20 & 0.02 \\
\hline Estor & 166 & 0 & 10 & & 14 & & 24 & & 29 & & 40 & & 1,151 & 1.32 & 1,335 & & 1,512 & & 1,712 & & 1,849 & 1.52 \\
\hline Finlan & 874 & 2.14 & 1,056 & 2.12 & 840 & 1.62 & 881 & 1.58 & 877 & 1.42 & 946 & 1.39 & 1,131 & 1.30 & 1,269 & 7 & 1,551 & 49 & 1,869 & 1.63 & 2,026 & 1.67 \\
\hline & 2,444 & 30.51 & 3,510 & 27.07 & 3,347 & 25.72 & 3,969 & 25.01 & 1,806 & 23.94 & 15,598 & 22.94 & 16,945 & 19.49 & 16,866 & 10 & 17,568 & 16.89 & 17,837 & 15.51 & 18,012 & 14.84 \\
\hline Ger & 19 & 0.05 & 192 & 0.38 & 319 & 0.61 & 779 & 1.39 & 1,175 & 1.90 & 1,730 & 2.54 & 2,614 & 3.01 & 3,717 & & 4,752 & 4.57 & 5,180 & & 308 & 4.37 \\
\hline & 328 & & 924 & & 960 & & 1,034 & & 1,096 & 1.77 & 1,143 & & & & 1,614 & & & & 738 & & 1,655 & 1.36 \\
\hline & 0 & & 0 & & 0 & & 4 & & 6 & 0.01 & 35 & & 1,655 & 1.90 & 1,779 & & 1,933 & & 2,151 & 1. & 2,318 & 1.91 \\
\hline Irelanc & 3 & 0.01 & 14 & 0.03 & 28 & 0.05 & 42 & 0. & 56 & 0.09 & 78 & 0.11 & 213 & 0.24 & 351 & 0.38 & 448 & 0.43 & 529 & 0.46 & 562 & 0.46 \\
\hline Ital & 7,196 & 17.65 & 8,083 & 16.20 & 7,984 & 15.38 & 8,013 & 14. & 9,441 & 15.27 & 9,949 & 14.63 & 15,068 & 17.33 & 15,567 & 16 . & 7,399 & 16.72 & 2,239 & 19.34 & 24,629 & 20.29 \\
\hline & 160 & 0 & 211 & & 225 & 0.4 & 257 & & 278 & 0.45 & 321 & & 339 & 0.39 & 303 & & 262 & 0.2 & 135 & 0.12 & 147 & 0.12 \\
\hline Lith & 29 & 0.07 & 45 & 0.09 & 55 & 0.11 & 77 & 0.14 & 141 & 0.23 & 159 & 0.23 & 167 & 0.19 & 166 & 0. & 180 & 0.17 & 189 & 0.16 & 198 & 0.16 \\
\hline & 0 & & 28 & & 27 & & 42 & & 52 & & 87 & & 113 & & 142 & & 263 & & 405 & & 541 & 0.45 \\
\hline & 0 & & 0 & & 0 & & 0 & & 1 & 0 & 0 & & 43 & 0. & 56 & & 63 & & 85 & 0. & 96 & 0.08 \\
\hline Nethe & 202 & 0.50 & 230 & 0.46 & 179 & 0.34 & 154 & 0.28 & 170 & 0.27 & 180 & 0.26 & 294 & 0.34 & 376 & 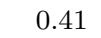 & 453 & 0.44 & 542 & 0.47 & 657 & 0.54 \\
\hline D. & & 217 & 1,618 & 80 & 1,728 & 3.33 & 1,982 & & 2,211 & 3.58 & 2,681 & & & 3.35 & 3,218 & & 1,212 & & 99 & & 1,386 & 3.61 \\
\hline & 666 & 1.63 & 820 & 1. & 834 & 1.6 & 860 & & 933 & 1.51 & 1,187 & 1. & 1,524 & 1.75 & 2,234 & & 3,477 & 3.34 & 2,959 & 2.57 & 2,637 & 2.17 \\
\hline Roma & 0 & 0.00 & 437 & 0.88 & 501 & 0.97 & 625 & 1.12 & 736 & 1.19 & 1,153 & 1.70 & 1,479 & 1.70 & 1,793 & 1.94 & 2,203 & 2.12 & 3,146 & 2.74 & 3,675 & 3.03 \\
\hline & 17 & & 37 & & 22 & & 16 & & 15 & & 19 & & 56 & & 81 & & 121 & & 173 & & 216 & 0.18 \\
\hline Slov & 0 & & 0 & & 0 & & 0 & & 0 & & 0 & & 543 & & 557 & & 633 & 0.61 & 676 & 0.59 & 679 & 0.56 \\
\hline Spa & 16 & 21.86 & 10,001 & 20.04 & 10,948 & 21.09 & 12,309 & 22.04 & 13,358 & 21.60 & 14,121 & 20.77 & 14,670 & 16.87 & 14,537 & 15.75 &, 201 & 14.61 & 056 & 13.09 & 15,092 & 12.43 \\
\hline & & & & & & 10.86 & & & & & & & & & & & & & 11,935 & 10. & 13,544 & 11.16 \\
\hline United Kingdom & 2,458 & 6.03 & 2,577 & 5.16 & 2,932 & 5.65 & 3,376 & 6.05 & 3,926 & 6.35 & 4,487 & 6.60 & 6,560 & 7.54 & 6,843 & 7.41 & 7,392 & 7.10 & 7,902 & 6.87 & 8,276 & 6.82 \\
\hline Total & 0,780 & .00 & 910 & 100.00 & 900 & 0.00 & 344 & 00.00 & 61,839 & 0.00 & 67,995 & 0.00 & ;,945 & .00 & 327 & 0.00 & ,045 & 0.00 & 983 & 100.00 & 121,380 & 00.00 \\
\hline
\end{tabular}

Source: Own calculations. 
the end of the year is finally calculated as ${ }^{6}$

$$
T O A S_{i, t}= \begin{cases}T O A S_{i, t-1}+P L B T_{i, t} \times(1-\tau)-D_{i, t} & \text { if } \quad P L B T_{i, t} \geq 0 \\ T O A S_{i, t-1}+P L B T_{i, t} & \text { if } \quad P L B T_{i, t}<0 .\end{cases}
$$

In Equation D.14, $\tau$ is the statutory corporate income tax rate in $t=0$ which is held constant over the entire simulation period. To estimate profit distributions, $D_{i, t}$, in Equation D.14, a company-specific payout ratio derived from historical data is multiplied with an estimate of distributable profits. Based on financial statement information from the final year of the presimulation period, $t=-1$, the payout ratio, $D I V R_{i}$, is computed as

$$
D I V R_{i}= \begin{cases}\min \left(1, \max \left(0, \frac{P L_{i,-1}-\left(S H F D_{i,-1}-S H F D_{i,-2}\right)}{P L_{i,-1}}\right)\right) & \text { if } \quad P L_{i,-1}>0 \\ \min \left(1, \max \left(0, \frac{P L_{i,-1}-\left(S H F D_{i,-1}-S H F D_{i,-2}\right)}{0.06 \times T O A S_{i,-2}}\right)\right) & \text { if } \quad P L_{i,-1} \leq 0\end{cases}
$$

where $P L_{i,-1}$ equals historical book income net of taxes in $t=-1$ (AmADEus item ' $\mathrm{P} / \mathrm{L}$ for Period [= Net income]') and the differential $\left(S H F D_{i,-1}-S H F D_{i,-2}\right)$ is the change in equity capital (AmADEus item 'Shareholders funds') during year $t=-1$ which is supposed to represent retained earnings in $t=-1 .^{7}$ Note that I deviate from Graham \& Kim, 2009, p. 33 insofar as I use after-tax income in the denominator but not taxable income. If after-tax income is negative, I again rely on Graham \& Kim, 2009, p. 33 and divide by $0.06 \times T O A S_{i,-2}$ in order to estimate $D I V R_{i}$. For the purpose of increasing total assets going forward during the remaining years of the simulation period $t=[1,9]$, I assume distributable profits to equal simulated pre-tax book income net of estimated statutory income tax expense.

In the further course of the calculations, the simulated values of annual pre-tax book income for $t=[0,9]$ serve as a basis for determining annual taxable incomes in a first step. Note that I explicitly apply tax law provisions on an accounting income measure in order to calculate taxable income rather than indirectly estimating it. This approach, which differs substantially from existing studies from the U.S., should reproduce more closely the assessment procedure as actually carried out by the tax authorities. The tax rules as of $t=0$ are applied over the entire simulation period in order to appropriately account for the fact that managers have no perfect

\footnotetext{
6 In contrast to Graham \& Kim, 2009, p. 33 who seem not to distinguish between positive and negative earnings when updating total assets, I neither assume a negative income to be taxed nor a profit distribution to occur if current-year pre-tax book income is negative.

7 See Oestreicher, Koch, et al., 2013, p. 24 who apply a quite similar approach to estimate profit distributions.
} 
foresight relating to future tax reforms. However, if a tax law change for $t>0$ has already been announced in $t=0$, then the amended tax rule is applied starting from the year of its envisaged entry into force. Annual tax payments are calculated by multiplying the determined tax bases by the applicable corporate income tax rate. In this, I take into account the progressiveness of the tax scale and reduced tax rates for small and medium-sized companies, if available at all. ${ }^{8}$ Using a discount factor of six percent, the resultant stream of estimated tax payment is discounted to its present value in year $t=0$. The second step consists of adding $€ 1$ to $P L B T_{i, t}$ and repeating the determination of annual taxable incomes, the calculation of tax payments and the computation of the tax payment stream's present value in year $t=0$. Finally, the marginal tax rate of company $i$ in year $t$, obtained from simulation run $s, M T R_{i, t, s}$, is calculated in the third step as difference between the present values of the two tax payment streams. Repeating the simulation procedure 200 times for each company-year yields 200 different forecasts of pre-tax book income and, consequently, 200 estimates of the marginal tax rate. I consider the average over the 200 estimates of the marginal tax rate to be the expected marginal tax rate for company $i$ in year $t$ :

$$
M T R_{i, t}=\frac{\sum_{s=1}^{200} M T R_{i, t, s}}{200} .
$$

I exclude from the simulation Estonian companies. In Estonia, corporate profits are not taxable in the year earned but only upon distribution to the shareholders. Therefore, taxable income is not determined on an accrual basis but on a cash basis instead, making the application of typical tax rules redundant.

\subsection{Coding of tax rules}

\subsubsection{Tax treatment of dividend income}

According to the EU Parent Subsidiary Directive, profit distributions between affiliated companies situated in the European Union may only be taxed once. At the level of the recipient, this can be achieved by two alternative means: The residence state of the parent company receiving distributed profits can either exempt dividend income from taxation, or tax such income while granting the parent company the right to credit the foreign corporate tax attributable to that income against domestic tax liabilities. The application of the exemption method does

8 See Table D.17 in the appendix for an overview. 
not preclude that the residence state of the parent company may treat up to five percent of the dividend received as non-deductible expenses for tax purposes. Then, only 95 percent of received dividends are actually tax-exempt. Table D.12 in the appendix gives an overview over the methods applied in the EU Member States during 2003 and 2013.

An adjustment of simulated PLBT for the tax treatment of received dividends requires the amount of the latter to be specified. In the absence of other reference points, I perform the following multi-stage approximation procedure in order to obtain estimates of dividend income over $t=[0 ; 9]$. Firstly, I calculate company-specific ratios of financial revenue (labelled FIRE $E_{i, t}$ ) to $P L B T_{i, t}$, denoted by FINRET $T_{i, t}$, using historical financial statement data from the last five years of the pre-simulation period $(t=[-5 ;-1])$. I assume the median of FINRET $T_{i, t}$ over $t=[-5 ;-1]$ to represent the company's characteristic fraction of financial income in the overall result that can be expected to be realised in the future, too. ${ }^{9}$ By multiplying this fixed ratio with the simulated PLBT, I obtain forecasts of FIRE. ${ }^{10}$

In a third step, I account for the fact that financial revenues in AMADEus do not only include dividend income. The second major type of financial revenue is income from debt instruments. Thus, I need to deduct a portion of estimated interest revenue from the simulated values of FIRE in order to get estimated dividend income. The size of interest revenue depends on the nominal amounts of the debt securities held and the interest rates on those securities. Regarding estimation of the former, AMADEus does only report the aggregate carrying amount of 'Other Fixed Assets' (OFAS) in which both debt investments (labelled DEBTINV) and equity investments are included. Hence, I need some guideline data indicating the relative share of these two subcategories of financial assets. Bureau van Dijk's OrBis database uncovers, at least in the case of consolidated balance sheets of listed companies, the composition of OFAS in greater detail. I consider the ORBIS item 'Long Term Receivables' to correspond to DEBTINV and compute for all available company-years the ratio of DEBTINV to OFAS. All resultant company-specific ratios between zero and one are then averaged over country $j$, industry $k$ and year $t$, provided that at least two company-specific ratios are available for averaging. By

9 Indeed, the assumption of a fixed relation between financial income and pre-tax book income is arguable. However, to a certain extent, it reflects the notion that in the presence of economic integration affiliated companies show similar earnings trends over time, thereby giving rise to some degree of company-specific correlation between the amount of received profit distributions from affiliates and total book income.

${ }^{10}$ If for a company-year there are less than five historical records available and the median cannot be determined company-specifically, I fall back on a group-specific median over $t=[-5,-1]$ instead. The respective groups are formed in the same manner as above for the purpose of group-specific GMM estimation of simulation parameters (see Section 4.2). 
multiplying the mean of $\frac{D E B T I N V_{j, k, t}}{O F A S_{j, k, t}}$ over $t=[-3,-1]^{11}$ with updated $O F A S_{i, t}{ }^{12}$, I receive company-specific estimates of $D E B T I N V_{i, t}$ over $t=[0,9]$.

By multiplying the country-specific long-term interest rate in year $t=0\left(\operatorname{LTIR}_{j, 0}\right)$ provided by $E C B, 2016^{13}$ with $D E B T I N V_{i, t}$, estimates for interest revenue over $t=[0,9]$ are obtained. Finally, I compute dividend income as the difference between simulated financial revenue and estimated interest revenue. The determination of both income components is summarised by the following formulas:

$$
\begin{aligned}
& \operatorname{INTREV_{i,t}}=\max \left(0, \min (\underbrace{P L B T_{i, t} \times \min \left(F I N R E T_{i}, 1\right.}_{F I R E_{i, t}}),\right. \\
& \underbrace{T O A S_{i, t} \times \frac{O F A S_{i,-1}}{T O A S_{i,-1}} \times \frac{\sum_{t=-3}^{-1} \frac{D E B T I N V_{j, k, t}}{O F A S_{j, k, t}}}{3}}_{D E B T I N V_{i, t}} \times L T I R_{j, 0}))
\end{aligned}
$$

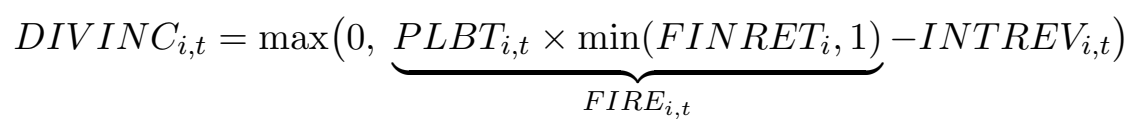

In Equations D.17 and D.18, I restrict FINRET $T_{i}$ to be not larger than one in order to avoid that the tax base and thus the marginal tax rate become negative only due to a tax exemption of a potentially arbitrarily high estimate of dividend income.

A partial or full tax exemption of dividend income leads to permanent differences between book and tax income. No such differences arise when the credit method is applied because then the tax relief does not apply to the tax base but to the amount of tax liabilities. However, both methods result in identical tax payments if the corporate income tax rate in the source country of the dividend-paying subsidiary company is equal to or higher than the corporate income tax rate in the country of the receiving parent. The credit method comes with a disadvantage only if the parent company faces a higher corporate income tax rate than its subsidiary. As I have no indication on the origin of received dividends, I assume that the entire amount of estimated dividend income falls within the scope of the EU Parent Subsidiary Directive and that the tax

11 OrBIS data are only available from 2005 onwards. Averaging the DEBTINV-to-OFAS ratio over $t=[-3,-1]$ is thus not possible if $t=0$ corresponds to the real years 2003 to 2007 . Therefore, I rely for $t=0 \equiv 2007$ on the mean of the DEBTINV-to-OFAS ratio over 2005, 2006 and 2007, for $t=0 \equiv 2006$ on the mean of the DEBTINV-to-OFAS ratio over 2005 and 2006 and for $t=0 \equiv\{2003,2004,2005\}$ on the DEBTINV-to-OFAS ratio of 2005 .

12 Other fixed assets are updated by applying the company-specific ratio of OFAS to TOAS of the last year of the pre-simulation period, i.e. $\frac{O F A S_{i,-1}}{T O A S_{i,-1}}$, on updated $T O A S_{i, t}$ over $t=[0,9]$.

13 As the interest rate data are provided on a monthly basis, I compute yearly averages. 
consequences of a tax credit are equal to those of a full exemption of dividends. ${ }^{14}$ Consequently, I subtract the full amount of $D I V I N C_{i, t}$ from simulated $P L B T_{i, t}$ when dividend income is either tax-exempt or a tax credit is granted, whereas I subtract an amount equal to $0.95 \times D I V I N C_{i, t}$ if received dividends are subject to a 95 percent tax exemption.

\subsubsection{Group taxation}

The majority of EU Member States has implemented group taxation systems that account for the fact that affiliated companies form an economic unit. Those countries water down the general rule of taxing companies separately by allowing losses to be surrendered between group companies or possibly also by eliminating interim results from intra-group transactions. As the Amadeus database does not contain information on intra-group transactions, I focus on the extended opportunities of loss recognition when simulating marginal tax rates. All systems provide an intra-group loss offset in general, but there are differences in how this is technically achieved. Table D.13 in the appendix summarises the regimes and loss offsetting techniques applied in the countries and years under scrutiny.

The most common method is pooling onto parent where the group companies' individual taxable incomes are aggregated ('fiscal unity') or even consolidated at the level of the group parent company. Under this concept, an inter-company loss relief is achieved by means of pooling profits and losses at the parent level. With the exception of Denmark, the pooled result is also taxed at the parent level. By contrast, in Denmark no joint taxation of the pooled result is carried out at the parent level. Rather, the pooled result is apportioned between the group companies and taxed at the individual companies' levels. If the pooled result is positive, then each profitable group member is assigned a proportion in the group's subtotal of losses, according to its relative share in the group's subtotal of profits, available for deduction from its profit. By contrast, if an overall loss occurs at the group level, then the group's subtotal of profits is apportioned among the loss-making group members, according to their respective shares in the group's subtotal of losses, in order to reduce those companies' current-year losses.

The United Kingdom, Ireland, Cyprus, Malta, Latvia and, since 2010, also Lithuania apply group relief provisions. Under those regimes there is no joint tax assessment of the group

14 A similar assumption is made by Oestreicher, Koch, et al., 2013, pp. 19 sq. The EU Parent Subsidiary Directive does not apply to dividends received from subsidiaries situated in third states. Nevertheless, EU Member States' domestic tax laws regularly provide a double taxation relief on a unilateral basis, with the exemption method being nowadays the dominant method (Endres \& Spengel, 2015, pp. 118 sqq.). 
companies. Instead of pooling the individual incomes, group companies that incur losses are generally allowed to transfer their losses to profitable members of the tax group, thereby reducing the tax bases of the latter. In order to avoid multiple utilisation of losses that are transferred in this way, they are excluded from inter-period loss offset. Group contribution systems are used in Finland, Sweden and, until 2009, Lithuania. As in the case of group relief, no joint tax assessment takes place. Group contribution differs from group relief in the fact that not losses are transferred to profitable group members. By contrast, profitable group members are permitted to make tax-deductible payments to loss-making group members that in exchange recognise these payments as taxable operating revenue, thereby reducing their tax losses.

In contrast to financial statement data that are available on an annual basis, AmADEus data on ownership structures reflect the situation of October 2014. It is thus necessary to assume them to be also valid for the past. AmADEus contains information on group structures under company law, but group taxation provisions are applied on tax consolidated groups. I focus on national group taxation systems and employ the tax group structures processed and provided by Oestreicher, Koch, et al., 2013. Owing to data restrictions, Oestreicher, Koch, et al., 2013 do not establish tax group structures for Cyprus, Ireland, Latvia, Lithuania, Malta and Slovenia. Where the formation of tax consolidated groups is facultative, the assumption is made that a tax group is formed whenever the relevant conditions are satisfied. However, the tax law in Poland imposes rigorous conditions that must be fulfilled by Polish companies in order to form a tax group. ${ }^{15}$ In particular, the share capital of the individual companies forming a tax group must be at least 1 million złoty and the annual overall result of the tax group must not be negative. Even more, the tax group's total net income of each year must not be less than three percent of the total gross income earned by all companies forming the tax group. If these conditions are not satisfied, the tax group is instantaneously considered to have been dissolved (Bacia, 2007, pp. 52 sq.). As a result, tax groups in Poland are rare (Binkowski \& Michaliszyn, 2003, p. 344) which is why I refrain from modelling group taxation in Poland.

In the course of estimating the simulation parameters (see Section 4.2), all companies were required to have at least four historical year observations available in order to remain in the sample. From this it follows that for some tax groups only a fraction of the original group structure is still represented in the simulation sample. In extreme cases, only one member of a given tax group has 'survived' the parameter estimation procedure. In order to be able to model

15 See Bacia, 2007 for institutional details. 
inter-company loss relief, a minimum number of two group members must be available. Group taxation is thus not modelled for tax groups that are still only represented by one company.

The computational implementation of the three different loss offsetting techniques is carried out following the approach chosen by Oestreicher, Koch, et al., 2013, pp. 20 sq. In case of pooling onto parent, the preliminary taxable income after group taxation (but before inter-period loss offset) of company $p$, which is the parent of a tax group formed by the companies $i=1, \ldots, p, \ldots, I$, is calculated as

$$
T I_{p, t}^{g t a x}=T I_{p, t}+\sum_{\substack{1 \leq i \leq I \\ i \neq p}} T I_{i, t},
$$

where $T I_{p, t}$ and $T I_{i, t}$ denote preliminary taxable income before group taxation of the group parent and group member $i$, respectively. Under the pooling approach, each group member $i$ 's $\neq p$ preliminary taxable income is attributed to the group parent. Consequently, the taxable income of each group member $i \neq p$ after group taxation (but before inter-period loss offset) is zero:

$$
T I_{i \neq p, t}^{g t a x}=0 .
$$

A different algorithm is applied when tax law provides an intra-group transfer of profits or losses. The implementation of group contribution and group relief provisions is based on the above-described Danish concept of apportioning losses to the members of the tax group:

$$
T I_{i, t}^{\text {gtax }}= \begin{cases}T I_{i, t} \times \frac{\sum_{i} T I_{i, t}}{\sum_{i} \max \left(0, T I_{i, t}\right)} & \text { if } \quad \sum_{i} T I_{i, t} \geq 0 \wedge T I_{i, t} \geq 0 \\ 0 & \text { if } \quad \sum_{i} T I_{i, t} \geq 0 \wedge T I_{i, t}<0 \\ T I_{i, t} \times \frac{\sum_{i} T I_{i, t}}{\sum_{i} \min \left(0, T I_{i, t}\right)} & \text { if } \quad \sum_{i} T I_{i, t}<0 \wedge T I_{i, t}<0 \\ 0 & \text { if } \quad \sum_{i} T I_{i, t}<0 \wedge T I_{i, t} \geq 0\end{cases}
$$

The first two equations in the piecewise function D.21 are applicable if the pooled result of the tax group is positive. In this case, the subtotal of negative preliminary taxable incomes is apportioned among group members with positive preliminary taxable incomes in order to reduce those companies' tax bases. If the pooled result is negative, however, the subtotal of preliminary taxable incomes is attributed on a pro-rata basis to group members with negative preliminary taxable incomes to reduce those companies' current losses.

In processing the consequences of group taxation provisions it must be ascertained that the 
computation of marginal tax rates is still performed on a company-by-company basis rather than on the tax group level. At least in the case of group relief and group contribution, a change in the income of one group member affects the relative sizes of the subtotals of profits and losses at the group level and therefore also the company-specific allotment ratios governing the redistribution of pooled income among the members of the tax group. Consequently, each tax group member's relative share in an attributable profit or loss is directly dependent on which group member experiences the marginal increase in income. For the technical implementation this implies that the marginal increase in income by $€ 1$ must only be carried out at the level of one group member at a time, while leaving the incomes of all other group members unchanged.

\subsubsection{Thin capitalisation and interest capping rules}

4.3.3.1 Overview There are two prevailing groups of methods for limiting the tax deductibility of interest expenses. The first group comprises thin capitalisation rules that call for the leverage of a company not to be higher than a legally defined debt-to-equity ratio in order that the full amount of interest expenses may reduce the tax base. In other words, adhering to the ratio ensures a full tax deductibility of interest expenses which is why those ratios are referred to as 'safe haven' rules. Table D.15 in the appendix reveals that there are significant differences across countries in the definition which type of debt enters the numerator of the safe haven ratio. Although thin capitalisation rules have generally the objective of penalising excessive financing with related-party (internal) debt, in some countries the critical debt-to-equity threshold is determined by taking unrelated-party (external) debt into consideration, too. Above that, exceeding the permissible limit may in some countries cause also the tax-deductible amount of interest payments for unrelated-party debt to become restricted.

The second group consists of so-called interest capping rules that do not evaluate the balance sheet of a company but its profit and loss account instead. Under interest capping rules, net interest expenses paid on all types of debt that go beyond a certain gross operating margin are excluded from tax deduction. Consequently, interest expenses up to the amount of interest revenue are tax-deductible in any case and only the expense in excess is subject to limitation, unless the company has realised a sufficiently high margin of operating income. Non-deductible interest expense of one year usually qualifies for a carry-forward in order to use it for a deduction from tax bases of future years. The interest capping rules in France, Germany and Spain do not 
apply to companies that are not members of consolidated groups.

When interest deductibility restrictions take effect, then an incremental increase in the concerned interest expenses does no longer result in a tax saving equal to the marginal tax rate. Simulated marginal tax rates that are intended to reflect the tax incentives for debt financing are therefore set to zero if a company has already exploited all its debt-related tax benefits in the first year of the simulation period. ${ }^{16}$ Yet limitations on interest deductibility appear also to be relevant when measuring companies' tax incentives in investment decisions. If tax law qualifies a company to be excessively financed with debt, then the non-conforming portion of interest expense that has already reduced pre-tax book income must be 'added back' to the tax base. Therefore, interest deductibility restrictions have the potential to increase the marginal tax rate.

4.3.3.2 Thin capitalisation rules Where thin capitalisation rules refer to a safe-haven ratio of total debt to equity, I derive from total assets, updated according to the clean-surplus relation, annual estimates of the company's equity and debt capital $\left(E Q U I T Y_{i, t}\right.$ and $D E B T_{i, t}$, respectively). To this end, I multiply an equity-to-assets ratio, calculated from financial statement data from the final year of the pre-simulation period and held fixed over the entire forecasting horizon $t=[0,9]$, with the annual estimates for total assets:

$$
\begin{aligned}
& E Q U I T Y_{i, t}=T O A S_{i, t} \times \frac{S H F D_{i,-1}}{T O A S_{i,-1}} \\
& D E B T_{i, t}=T O A S_{i, t}-E Q U I T Y_{i, t}
\end{aligned}
$$

In the majority of Member States, thin capitalisation rules aim at limiting the deduction of interest on internal debt. Since the Amadeus data do not provide a separate disclosure of debt from related parties, I use the 2003 to 2013 U.S. Direct Investment Abroad (USDIA) surveys of $B E A, 2003-2013$ for guideline purposes and calculate for each year over the forecasting horizon country-specific ratios of internal debt to equity, denoted by INTDEBTRATIO $j,{ }^{17}$

16 Graham (1996a, p. 54) raises the issue whether an average of expected marginal tax rates over the life of the debt instrument that take into account the potential of deducting the total amount of related interest rather than only an incremental unit of income would provide a more appropriate proxy for tax status in financing decisions. As the author notes, this would require to develop a different methodology to computing marginal tax rates. In line with prior research, I therefore stick to the standard definition of simulated marginal tax rates.

17 For 2003 to 2008, internal debt corresponds to 'Current liabilities and long-term debt from U.S. parents' reported in 'Table III.C 1. External Financing of Affiliates' and equity corresponds to 'Owners' equity' reported in 'Table III.B 1-2. Balance Sheet of Affiliates'. From 2009 on, data on internal debt are no longer available in this form. Alternatively, I use the figures reported in column 'Debt instruments-U.S. parent's receivables' of http://www.bea.gov/international/xls/usdia-current/USDIA\%20Position\%20Selected\% 
By multiplying the country-specific INTDEBTRATIO ${ }_{j, 0}$ with the company-specific simulated amounts of equity capital over $t=[0,9]$ according to D.22, I obtain estimates for the book values of internal and external debt:

$$
\begin{aligned}
& I N T D E B T_{i, t}=\min \left(D E B T_{i, t}, \max \left(0, E Q U I T Y_{i, t} \times I N T D E B T R A T I O_{j, 0}\right)\right) \\
& E X T D E B T_{i, t}=D E B T_{i, t}-I N T D E B T_{i, t} .
\end{aligned}
$$

The minimum/maximum functions ensure that internal debt is neither estimated to be negative due to a negative value on $\frac{S H F D_{i,-1}}{T O A S_{i,-1}}$ in Equation D.22 nor to be greater than total debt.

During 2003 and 2006, the Czech thin capitalisation rules were targeted towards debt from foreign sources, and between 2003 and 2012, the Portuguese regulations were focused on foreign related party debt and foreign related party equity. ${ }^{18}$ In this regard, too, USDIA data provide indication for further dividing the total amount of simulated debt (and for the Portuguese case also equity) into a portion of domestic and one of foreign origin. To calculate the percentage share of foreign party-related debt to total debt, I divide the sum of 'Current liabilities and longterm debt' from U.S. parents, other U.S. persons and other foreign persons by the total amount of 'Current liabilities and long-term debt' reported for the respective country. Analogously, I compute the portion of foreign held equity capital for Portuguese companies.

The portion of debt in excess of the permissible debt-to-equity ratio is determined as

$$
E X C D E B T_{i, t}=\max \left(0, D E B T_{i, t}^{*}-\alpha \times \max \left(0, E Q U I T Y_{i, t}\right)\right)
$$

where $D E B T^{*}$ denotes the type of debt affected by the thin-capitalisation rules (total, external, foreign, internal or internal foreign debt) and $\alpha$ is the numerator in the applicable safehaven debt-to-equity ratio reported in Table D.15 in the appendix. The related amount of non-deductible interest $\left(N D I_{i, t}^{t c a p}\right)$ to be added back to the tax base is given by

$$
N D I_{i, t}^{\text {tcap }}=\max \left(0, \min \left(E X C D E B T_{i, t}, D E B T_{i, t}^{*}\right) \times I R_{i, 0}\right)
$$

If the simulated marginal tax rate shall be used to proxy the tax incentives for debt financing, the tax base is not increased by $N D I_{i, t}^{\text {tcap }}$. Rather, the marginal tax rate is set to zero if an interest deductibility restriction takes effect in $t=0$, indicating that an additional unit of interest paid

20Countries\%202009-2014.xlsx, whereas data on equity are gathered from 'Table II.B 2. Balance Sheet of Affiliates-Liabilities and Owners' Equity'.

18 Since 2006, the rules did no longer apply to debt from EU resident related parties. As I am, however, not able to distinguish between debt from EU-related and non-EU-related parties, I ignore this interim abolishment. 
today does not result in a tax saving equal to the marginal tax rate.

In Equation D.27, $I R_{i, 0}$ is a company-specific debt interest rate defined as the ratio of interest paid to interest-bearing liabilities. Using an approach similar to that in Oestreicher, Koch, et al., 2013, pp. 15 sq., I, firstly, calculate for each year during $t=[-4,0]$ the amount of interest-bearing liabilities by adding together the values of the Amadeus items 'Long Term Debt' (LTDB), 'Loans' (LOAN) and 'Other current liabilities' (OCLI), provided that at least one of the three values is given. I denote the resultant sum by LIAB. Then, I compute two different values for the company-specific debt interest rate by applying the following formulas:

$$
\begin{aligned}
& I R 1_{i, t}=\min \left[2, \frac{\min \left(\max \left(0, I N T E_{i, t-1}\right), \max \left(0, F I E X_{i, t-1}\right)\right)}{0.5 \times\left(L I A B_{i, t-1}+L I A B_{i, t-2}\right)}-\left(C I R_{j, t-1}-C I R_{j, t}\right)\right] \\
& I R 2_{i, t}=\min \left[2, \frac{\min \left(\max \left(0, I N T E_{i, t-1}\right), \max \left(0, F I E X_{i, t-1}\right)\right)}{0.5 \times\left(L I A B_{i, t-1}+L I A B_{i, t-2}\right)} \times \frac{C I R_{j, t}}{C I R_{j, t-1}}\right] .
\end{aligned}
$$

In cases where AmADEus does not disclose information on 'Interest Paid' (INTE), I rely on the aggregate value of 'Financial Expenses' (FIEX) instead. As the interest rates are calculated using historical data prior to the first year of the simulation periods, they are adjusted for a time trend in the country-specific interest rate (CIR) development from $t=-1$ to $t=0$. In Equation D.28, the time trend is captured as annual difference in the interest rate on loans to the private sector, whereas in Equation D.29 the annual rate of change in the lending rate is used as adjustment factor. In either case, the company-specific debt interest rate is restricted to be not higher than 200 percent. For the purposes of determining the interest expenses over the simulation period $t=[0,9]$, the median value of $\max \left(\operatorname{IR} 1_{i, t}, \operatorname{IR} 2_{i, t}\right)$ over $t=[-4,0]$ is considered to be the relevant value for $I R_{i, 0}$ in Equation D.27. If less than five observations are available and the company-specific median cannot be determined, I again fall back using the median for the respective company's peer group ${ }^{19}$ instead.

4.3.3.3 Interest capping rules Germany and Italy employ interest capping rules since 2008, Spain does so since 2012 and Portugal limits tax-deductible expenses for debt financing by means of an interest capping rule since 2013. Interest capping rules lay down that a company is allowed to deduct interest expenses up to an amount equal to interest revenues plus net interest expenses up to an amount equal to a certain proportion of EBITDA from its tax base. In order to determine the amount of non-deductible interest expense $\left(N D I_{i, t}^{i c r}\right)$, the following set

19 See Section 4.2 for the grouping criteria. 
of formulas is applied:

$$
\begin{aligned}
& E B I T D A_{i, j=D E, t}=P L B T_{i, t}-0.95 \times D I V I N C_{i, t}+N E T I N T E X P_{i, t}+D A_{i, t} \\
& E B I T D A_{i, j=I T, t}=P L B T_{i, t}-D I V I N C_{i, t}+N E T I N T E X P_{i, t}+D A_{i, t} \\
& E B I T D A_{i, j=\{E S, P T\}, t}=P L B T_{i, t}+N E T I N T E X P_{i, t}+D A_{i, t} \\
& \text { with NETINTEXP } P_{i, t}=\max \left(0, D E B T_{i, t} \times I R_{i, 0}\right)-I N T R E V_{i, t} \\
& N D I_{i, t}^{i c r}=\max \left(0, N E T I N T E X P_{i, t}-\max \left(0, \beta \times E B I T D A_{i, t}\right)\right)
\end{aligned}
$$

The exact definition of EBITDA varies between countries. In any case, pre-tax book income is upwardly adjusted by the net interest expense (i.e. the difference between interest expenses and revenues) and depreciation and amortisation allowances (hereafter DA). While in Spain and Portugal received dividends are to be included in the EBITDA (see Equation D.32), the German and Italian rules dictate the amount of (tax-exempt) dividend income to be excluded from EBITDA (see Equations D.30 and D.31). Dividend income and interest revenues are determined in accordance with Equations D.18 and D.17, while interest expenses are computed as the product of the company-specific interest rate and total debt according to Equation D.23. To obtain yearly estimates for depreciation and amortisation, I figure out company-specific ratios of depreciation expense (AMADEUs item DEPR) to total assets at the end of the final year of the pre-simulation period, and I apply that ratio on each year's simulated balance sheet total:

$$
D A_{i, t}=\max \left(0, \min \left(T O A S_{i, t}, T O A S_{i, t} \times \frac{D E P R_{i,-1}}{T O A S_{i,-1}}\right)\right)
$$

The minimum/maximum functions ensure that DA is kept in the range between zero and the simulated book value of total assets. The variable $\beta$ in Equation D.33 refers to the percentage of EBITDA up to which net interest expense is fully deductible. With the exception of Portugal, $\beta$ equals 0.3. For the tax year 2013, Portuguese companies were granted an interest deduction capacity of 70 percent of EBITDA or $€ 3$ million, whichever amount is higher. In the case of tax consolidated groups, the EBITDA and NDI calculations must be applied at the tax group level.

The resulting NDI must not reduce the tax base of the current year, but it may be carried forward to future years. In Germany, such interest carry-forward is allowed for an infinite period of time. In Italy, the opportunity of a five-year interest carry-forward was introduced in 2010. Portugal and Spain impose time limitations of five and 18 years, respectively. In the 
presence of time limitations, it is important to not simply accumulate interest carry-forwards of different temporal origins over time. To be able to account for a potential forfeiture of parts of interest carry-forwards, I form separate bins for each year to which are assigned the respective annual amounts of NDI. This ensures that accrued interest carry-forwards are used up gradually, according to their order of formation.

The interest deductibility rules in Bulgaria, France (since 2007) and Romania combine elements of thin capitalisation and interest capping provisions. Bulgarian companies that do not exceed the safe haven debt-to-equity ratio are not subject to restrictions on interest deductibility. If the threshold is crossed, however, interest expenses paid to related parties are non-deductible inasmuch as they go beyond the sum of interest revenue and 75 percent of the EBIT (defined as pre-tax book income plus net interest expense). From 2007 onwards, non-deductible interest can be carried forward for five years. The Romanian approach is nearly identical except that the threshold is calculated as the sum of interest revenue and ten percent of the other income. Romania provides a time-unlimited interest carry-forward. The French post-2006 rules are more sophisticated. Related party interest expenses of companies belonging to a consolidated group must pass a two-stage test procedure. In a first step, an 'interest rate limitation test' is performed on related party interest expense. Interest expenses cannot be deducted for tax purposes inasmuch as the interest on internal debt exceeds the annual average variable interest of bank loans with a term to maturity longer than two years. In the second step, it follows a 'leverage test'. To retain full deductibility of the portion of related interest expense that is considered appropriate in the first step, that portion must be equal to or less than any one of the following three limits:

- Interest expense on internal debt in the amount of 1.5 times the company's equity

- 25 percent of the company's current pre-tax income before interest expenses on related party debt, depreciation and amortisation

- Interest income from intra-group lending

However, if the appropriate interest expense from the first step is above all these limits, then the related party interest is non-deductible to the extent that it exceeds the highest of the three limits. Lacking information about interest income accrued on intra-group lending, I assume it to equal half of total interest revenue derived from Equation D.17. If the excess amount is below the tax exemption limit of $€ 150,000$, no additional interest deductibility limitation applies on the 
second stage. Otherwise, the non-deductible amount of interest expenses may be carried forward indefinitely. However, a five percent reduction applies to the interest carry-forward, starting from the second year of its formation. Companies that belong to a tax consolidated group, determine the amount of non-deductible interest as before on a stand-alone basis. Therefore, any non-deductible interest increases the income to be attributed to the group parent. Instead of allowing non-deductible interest according to the 'leverage test' to be carried forward at the individual company level, tax groups may deduct a portion of the respective expenses from the aggregate tax base after all, provided that they successfully pass a third test. For this, related party interest expenses, net of payments within the tax group, must not exceed 25 percent of the tax group's adjusted EBITDA ${ }^{20}$. Then, the group parent may again subtract from the pooled tax base an amount equal to the sum of adjusted EBITDA and initially disallowed expenses under the 'leverage test' minus the amount of interest paid by tax group members to related parties outside the tax group (Charpentier \& Gelli, 2008, BDI/KPMG, 2009). Any remaining amount of non-deductible interest can finally be carried forward at the level of the tax group over an infinite period, being subject to an annual five percent reduction.

\subsubsection{Notional interest deduction}

Since 2007 Belgian companies are allowed to deduct a notional interest expense from their tax base before inter-period loss-offset. To this end, an annually defined rate ${ }^{21}$ is multiplied with an adjusted ${ }^{22}$ equity measure at the end of the preceding year. I calculate the book value of equity in accordance with Equation D.22 and deduct from it the book value of participations and other shares held as fixed assets. In the absence of sufficiently detailed AmADEus data on the composition of 'Other Fixed Assets', I again rely on consolidated financial statement data of listed companies in ORBIS to calculate a guideline ratio for equity investments. The approach is analogous to that chosen in 4.3.1 for the purpose of approximating debt investments. The sum of the items 'Investments' and 'Long Term Associated Companies' represent equity investments in other companies (EQINV). I calculate for each company-year with available data the ratio $\frac{E Q I N V_{i, t}}{T O A S_{i, t}}$. Where I have at least two observations per country-industry-year combination, I use

20 The adjusted EBITDA is defined as pre-tax income, increased by depreciation and amortisation and internal interest expense paid to related parties outside the tax group and reduced by dividend income received from other tax group members

21 The notional interest rate corresponds to the annual average interest rate on Belgian government bonds with a ten-year maturity.

22 See Anonymous, 2012, pp. 8 sq. for a detailed description of the adjustments to be made. 
all ratios with values between zero and one and average them over country $j$, industry $k$ and year $t$. Company-specific estimates of $E Q I N V_{i, t}$ over $t=[0,9]$ are then computed by multiplying the mean of $\frac{E Q I N V_{j, k, t}}{O F A S_{j, k, t}}$ over $t=[-3,-1]^{23}$ with the company-year-specific $O F A S_{i, t}$ forecast. The base equity for notional interest deduction (NID base) is thus calculated as

$$
N I D B A S E_{i, j=B E, t}=\max (0, E Q U I T Y_{i, t}-\underbrace{T O A S_{i, t} \times \frac{O F A S_{i,-1}}{T O A S_{i,-1}} \times \frac{\sum_{t=-3}^{-1} \frac{E Q I N V_{j=B E, k, t}}{O F A S_{j=B E, k, t}}}{3}}_{E Q I N V_{i, t}}) .
$$

The notional interest expense allowable for tax purposes is obtained by multiplying the NID base with the relevant NID rate. Companies whose turnover, balance sheet total or number of employees do not exceed certain thresholds qualify as small and medium-sized enterprises and are granted a 50 basis points higher rate. To derive estimates for turnover and employees, I calculate from the AmADEus data for the last year of the pre-simulation period a sales-toassets ratio $\left(\frac{T U R N_{i,-1}}{T O A S_{i,-1}}\right)$ and a personnel-to-assets ratio $\left(\frac{E M P L_{i,-1}}{T O A S_{i,-1}}\right)$, held them fixed and multiply theses ratios with the estimates for total assets over $t=[0,9]$. The notional interest deduction cannot cause the tax base to become negative. Before 2013, companies were allowed to carry-forward the non-deductible portion of NID expense over seven years.

Latvia introduced a notional interest deduction regime in 2010. Under the Latvian concept, companies were granted an imputed interest on the amount of undistributed profits of the preceding year, with the notional interest rate corresponding to the lending rate for non-financial companies as determined by the Bank of Latvia. To estimate the amount of retained after-tax profits, the dividend payout ratio from Equation D.10 is applied. As in Belgium, the notional interest expense had to be deducted from the current year's tax base before loss-offset and the deduction could not trigger the tax base to become negative. In contrast to Belgian companies, however, Latvia did not provide an NID carry-forward.

Since the Italian notional interest deduction regime was only introduced in December 2011 although it is applicable to the tax years from 2010 onwards, it affects only the marginal tax rates to be simulated for the years 2012 and 2013. Unlike the Belgium or Latvian concept, the Italian approach provides a reduction of the taxable income after inter-period tax loss-offset. Inasmuch as the amount of notional interest exceeds the tax base after tax-loss offset, it could

${ }^{23}$ Due to missing data for determining the mean values during 2003 and 2007, I fall back on the alternative approaches described in footnote 11 . 
be carried forward into the future without any time limit. The deductible amount equals three percent times 'adjusted new equity'. To obtain the qualifying 'adjusted new equity' of the current year, the equity at the end of 2010 needs to be upwardly and downwardly adjusted for certain events. By way of example, upward adjustments are required in case of contributions in cash or retention of profits, while downward adjustments need to be made if the company makes assignments in favour of shareholders (Leone \& Zanotti, 2012, p. 433). The 'adjusted new equity' of a specific year corresponds to the difference between the equity capital at the end of that year and the company's equity at the end of 2010, adjusted for the 2010 accounting income ( $P w C, 2015$, p. 997). I model the 'adjusted new equity' at the end of year $t$ as the difference between simulated equity at the end of year $t$, derived from Equation D.22, and the equity at the end of 2010, as reported under the Amadeus item $S H F D_{i, 2010}$, adjusted for the AmAdeus item $P L B T_{i, 2010}$.

Table D.14 in the appendix provides a summary overview over the design of notional interest deduction provisions in Belgium, Italy and Latvia.

\subsubsection{Inter-period tax loss offset}

In the final step of tax base determination, I model the consequences of inter-period tax loss offset. In contrast to profits that are taxed in the year earned, net losses do not correspondingly result in a negative tax payment, i.e. a tax refund, by the tax authorities. Instead, net tax losses can only be deducted from past or future profits by means of loss carry-back or carryforward. Table D.16 in the appendix shows that all countries under scrutiny provided the general possibility to carry-forward net tax losses to future years. In some countries, mostly from Eastern Europe, time restrictions on the carry-forward period were applied. Moreover, particularly since the beginning of the 2010s, offset restrictions regarding the amount of carry-forward losses were increasingly introduced. The 2013 legislation in Austria, Italy, Portugal and Slovenia allowed tax losses from prior years to offset no more than a portion between 50 and 80 percent of current year profits. The respective rules in France and Germany provided for an unlimited loss-offset up to an amount of $€ 1$ million, while no more than 50 or 60 percent of profits in excess of $€ 1$ million could be offset against carry-forward losses. The Danish and Spanish 2013 legislation required the application of such 'minimum taxation rules' only on companies that exceed certain taxable income or turnover thresholds, respectively. In Poland, the limitation was not made with 
respect to the current-year profit, but with respect to the stock of loss carry-forwards that could only be used up to half of its amount.

If the preliminary taxable income is negative and the company is not able to deduct the net loss from profits in the past by means of loss carry-back, then the taxable income after inter period tax loss-offset, i.e. the final tax base, equals

$$
T I_{i, t}^{t l o}=0 \quad \text { if } T I_{i, t}<0 \wedge \text { carry-back not available. }
$$

Provided that tax law does not deny loss carry-forward completely, the net loss is not lost. Rather, it can be used to reduce the positive taxable income of future periods. If time limitations on carry-forward are applied, the chronological utilisation of past losses must be accurately modelled. To this end, incurred tax losses are registered separately on an annual basis. When in a future year a positive taxable income occurs against which losses from the past can be settled, then older losses are used first. However, before a past loss from a specific year is actually deducted, it is verified that this loss is not older than than the length of the utilisation period once assigned to it. If the respective loss is older, then it is blocked for settlement.

Under carry-back provisions, a current loss is deducted from a previous year's taxable income after loss-offset. As a result, the respective tax base is retroactively reassessed and the taxes previously overpaid are subsequently refunded to the company. The time period over which the company may go back into the past to deduct a current loss and the amount up to which a deduction is possible differs between countries. Carry-back was available in France, Germany, Ireland, the Netherlands and the United Kingdom. The time limitations imposed varied between one and three years. In France (since 2011) and Germany, additional limitations regarding the deductible amount were applied. As indicated by the following equation, the upper limit of the carry-back amount is the negative value of the current loss. The lower limit is given by the sum of the positive tax bases during the permissible carry-back period $\left(\sum_{p=1}^{P} T I_{i, t-p}^{t l o}\right.$, where $P$ denotes the maximum number of years a loss may be carried back). However, in no case the carry-back amount has to exceed a potentially prescribed ceiling amount applicable in the current period $\left(\operatorname{LIMIT}_{i, t}\right)$ :

$$
T I_{i, t}^{t l o}=-\max \left(0, \min \left(-T I_{i, t}, \sum_{p=1}^{P} T I_{i, t-p}^{t l o}, L I M I T_{i, t}\right)\right) \text { if } T I_{i, t}<0 \wedge \text { carry-back available }
$$


If the preliminary taxable income is positive, it may generally be reduced by carry-forward losses from the past that have not yet expired in the current year $\left(L C F_{i, t}\right)$. A deduction is, however, only possible up to an amount equal to the current-year preliminary taxable income. Moreover, in the presence of a minimum taxation rule, the actual offset capacity $\left(\operatorname{LIMIT}_{i, t}\right)$ may be even lower:

$$
T I_{i, t}^{t l o}=T I_{i, t}-\min \left(L C F_{i, t}, T I_{i, t}, L I M I T_{i, t}\right) \quad \text { if } T I_{i, t}>0
$$

In order for the effects of inter-period tax loss offset to be appropriately reflected in simulated marginal tax rates it is necessary to approximate the amount of carry-forward losses as available at the beginning of the year 2003. If all companies would be treated as having no carry-forward losses to offset current earnings in 2003, the portion of quasi tax exempt companies would likely be significantly understated. Therefore, I assume pre-tax book income as reported in AMADEUs for the years 1994 through 2002 to equal taxable income before loss offset and model the development of the stock of carry-forward losses by applying the loss carry-over provisions as applicable in each year on that income.

\section{Evaluation}

\subsection{Descriptive statistics}

Simulated marginal tax rates are expected to be superior in identifying corporate tax incentives because they ensure a higher degree of variation across companies' tax statuses than other tax proxies. The greater variation results, first and foremost, from the explicit modelling of managers' expectations about future earnings development. Yet, additional differentiation between companies' tax statuses may be obtained by increasing the scope of tax rules considered in the calculation of expected tax payments. In order to investigate the significance of specific tax law provisions in simulating marginal tax rates, I gradually extend the scope of tax rules considered in the simulation process. In its coarsest form, the simulated marginal tax rate incorporates the regulations governing inter-period tax loss offset and the tax rate schedule. This variant is denoted by $m t r \_t l o$ and corresponds to the most common definition of simulated marginal tax rates in prior literature. An overview over the other marginal tax rate variants' definitions is presented in Table D.3. 
Table D.3: Definition of simulated marginal tax rates

\begin{tabular}{|c|c|}
\hline Variable name & Scope of tax rules considered \\
\hline$m t r \_t l o$ & Inter-period loss offset, tax rate schedule \\
\hline mtr_div_tlo & Inter-period loss offset, tax rate schedule, dividend income treatment \\
\hline mtr_div_tlo_tcapinv & $\begin{array}{l}\text { Inter-period loss offset, tax rate schedule, dividend income treatment, thin capitali- } \\
\text { sation/interest capping rules }\end{array}$ \\
\hline mtr_div_tlo_tcapinv_nid & $\begin{array}{l}\text { Inter-period loss offset, tax rate schedule, dividend income treatment, thin capitali- } \\
\text { sation/interest capping rules, notional interest deduction }\end{array}$ \\
\hline mtr_div_tlo_tcapfin & $\begin{array}{l}\text { Same as for } m t r \_d i v \_t l o \_t c a p i n v \text {, but the simulated marginal tax rate is set to } \\
\text { zero if incremental interest payment is not tax deductible in the first year of the } \\
\text { simulation period }\end{array}$ \\
\hline mtr_div_tlo_tcapfin_nid & $\begin{array}{l}\text { Same as for } m t r \_d i v \_t l o \_ \text {tcapinv_nid, but the simulated marginal tax rate is set } \\
\text { to zero if incremental interest payment is not tax deductible in the first year of the } \\
\text { simulation period }\end{array}$ \\
\hline$m t r \_t l o \_g t a x$ & Inter-period loss offset, group taxation, tax rate schedule \\
\hline$m t r \_d i v \_t l o \_g t a x$ & $\begin{array}{l}\text { Inter-period loss offset, group taxation, tax rate schedule, dividend income treat- } \\
\text { ment }\end{array}$ \\
\hline mtr_div_tlo_gtax_tcapinv & $\begin{array}{l}\text { Inter-period loss offset, group taxation, tax rate schedule, dividend income treat- } \\
\text { ment, thin capitalisation/interest capping rules }\end{array}$ \\
\hline mtr_div_tlo_gtax_tcapinv_nid & $\begin{array}{l}\text { Inter-period loss offset, tax rate schedule, dividend income treatment, thin capitali- } \\
\text { sation/interest capping rules, notional interest deduction }\end{array}$ \\
\hline mtr_div_tlo_gtax_tcapfin & $\begin{array}{l}\text { Same as for } m t r \_d i v \_t l o \_g t a x \_t c a p i n v \text {, but the simulated marginal tax rate is set } \\
\text { to zero if incremental interest payment is not tax deductible in the first year of the } \\
\text { simulation period }\end{array}$ \\
\hline mtr_div_tlo_gtax_tcapfin_nid & $\begin{array}{l}\text { Same as for } m t r \_d i v \_t l o \_g t a x \_t c a p i n v \_n i d \text {, but the simulated marginal tax rate } \\
\text { is set to zero if incremental interest payment is not tax deductible in the first year } \\
\text { of the simulation period }\end{array}$ \\
\hline
\end{tabular}

Notes: The table specifies which tax law provisions are included in the different versions of simulated marginal tax rates.

Table D.4 provides summary statistics for the various simulated marginal tax rates, broken down by simulation year. First of all, the number of companies for which sufficient data are available to take the effects of group taxation into consideration is always smaller than the total number of observations in each year. These smaller subsets of observations comprise both actual tax group members as well as those companies that do not belong to a tax group but are, however, resident in a country providing a group taxation system. Consequently, the respective subsets neither contain companies residing in countries where group taxation is generally not available, nor companies for which, due to data restrictions, marginal tax rates reflecting the tax consequences of group taxation could not be simulated, even though these companies might actually have been members of a tax group in the simulation year under study. In the following, I refer to the full set of observations as 'Panel A' and to the restricted panel as 'Panel B'.

An examination of the distributions of the marginal tax rate estimates for Panel A shows that the mean of $m t r \_t l o$ is consistently higher than the mean of any other proxy variant. With 
Table D.4: Summary statistics by simulation year

\begin{tabular}{|c|c|c|c|c|c|c|}
\hline Simulation year 2003 & $\mathrm{~N}$ & Mean & Std dev & Min & Median & Max \\
\hline \multicolumn{7}{|l|}{ Panel A } \\
\hline mtr_tlo & 40,614 & 0.2835 & 0.1115 & 0 & 0.34 & 0.4022 \\
\hline mtr_div_tlo & 40,614 & 0.2791 & 0.1149 & 0 & 0.3399 & 0.4022 \\
\hline mtr div tlo tcapinv & 40,614 & 0.2795 & 0.1143 & 0 & 0.3399 & 0.4022 \\
\hline mtr div tlo tcapinv nid & 40,614 & 0.2795 & 0.1143 & 0 & 0.3399 & 0.4022 \\
\hline mtr_div_tlo_tcapfin & 40,614 & 0.2718 & 0.1254 & 0 & 0.3399 & 0.4022 \\
\hline mtr_div_tlo_tcapfin_nid & 40,614 & 0.2718 & 0.1254 & 0 & 0.3399 & 0.4022 \\
\hline \multicolumn{7}{|l|}{ Panel B } \\
\hline mtr tlo gtax & 23,914 & 0.2928 & 0.1078 & 0 & 0.3423 & 0.4022 \\
\hline mtr_div tlo gtax & 23,914 & 0.2883 & 0.1116 & 0 & 0.3408 & 0.4022 \\
\hline mtr_div tlo_gtax tcapinv & 23,914 & 0.2885 & 0.1113 & 0 & 0.3408 & 0.4022 \\
\hline mtr_div_tlo_gtax_tcapinv_nid & 23,914 & 0.2885 & 0.1113 & 0 & 0.3408 & 0.4022 \\
\hline mtr_div_tlo_gtax_tcapfin - & 23,914 & 0.2833 & 0.1196 & 0 & 0.3407 & 0.4022 \\
\hline mtr_div_tlo_gtax_tcapfin_nid & 23,914 & 0.2833 & 0.1196 & 0 & 0.3407 & 0.4022 \\
\hline \multirow{2}{*}{\multicolumn{7}{|c|}{ Simulation year 2004}} \\
\hline & & Mean & Std dev & & & \\
\hline \multicolumn{7}{|l|}{ Panel A } \\
\hline mtr_tlo & 49,900 & 0.2714 & 0.1133 & 0 & 0.3298 & 0.389 \\
\hline mtr- div tlo & 49,900 & 0.2674 & 0.116 & 0 & 0.3293 & 0.389 \\
\hline mtr div tlo tcapinv & 49,900 & 0.2678 & 0.1156 & 0 & 0.3293 & 0.389 \\
\hline mtr_div_tlo_tcapinv_nid & 49,900 & 0.2678 & 0.1156 & 0 & 0.3293 & 0.389 \\
\hline mtr_div_tlo_tcapfin & 49,900 & 0.2604 & 0.1253 & 0 & 0.3291 & 0.389 \\
\hline mtr_div_tlo_tcapfin_nid & 49,900 & 0.2604 & 0.1253 & 0 & 0.3291 & 0.389 \\
\hline \multicolumn{7}{|l|}{ Panel B } \\
\hline mtr_tlo_gtax & 29,856 & 0.2778 & 0.1122 & 0 & 0.3381 & 0.389 \\
\hline mtr div tlo gtax & 29,856 & 0.2735 & 0.1152 & 0 & 0.3321 & 0.389 \\
\hline mtr_div_tlo_gtax_tcapinv & 29,856 & 0.2736 & 0.115 & 0 & 0.3321 & 0.389 \\
\hline mtr_div_tlo_gtax_tcapinv_nid & 29,856 & 0.2736 & 0.115 & 0 & 0.3321 & 0.389 \\
\hline mtr div tlo gtax tcapfin - & 29,856 & 0.2684 & 0.1223 & 0 & 0.3315 & 0.389 \\
\hline mtr_div_tlo_gtax_tcapfin_nid & 29,856 & 0.2684 & 0.1223 & 0 & 0.3315 & 0.389 \\
\hline \multicolumn{7}{|l|}{ Simulation year 2005} \\
\hline & $\mathrm{N}$ & Mean & Std dev & Min & Median & $\operatorname{Max}$ \\
\hline \multicolumn{7}{|l|}{ Panel A } \\
\hline mtr_tlo & 51,886 & 0.267 & 0.1126 & 0 & 0.3286 & 0.389 \\
\hline mtr_div_tlo & 51,886 & 0.2631 & 0.1153 & 0 & 0.3262 & 0.389 \\
\hline mtr_div_tlo_tcapinv & 51,886 & 0.2632 & 0.1152 & 0 & 0.3262 & 0.389 \\
\hline mtr_div tlo_tcapinv nid & 51,886 & 0.2632 & 0.1152 & 0 & 0.3262 & 0.389 \\
\hline mtr_div tlo tcapfin & 51,886 & 0.2614 & 0.1175 & 0 & 0.3259 & 0.389 \\
\hline mtr_div_tlo_tcapfin_nid & 51,886 & 0.2614 & 0.1175 & 0 & 0.3259 & 0.389 \\
\hline \multicolumn{7}{|l|}{ Panel B } \\
\hline mtr_tlo_gtax & 31,234 & 0.2718 & 0.112 & 0 & 0.33 & 0.389 \\
\hline mtr_div_tlo_gtax & 31,234 & 0.2676 & 0.1149 & 0 & 0.33 & 0.389 \\
\hline mtr_div_tlo_gtax_tcapinv & 31,234 & 0.2679 & 0.1145 & 0 & 0.33 & 0.389 \\
\hline mtr- div tlo gtax-tcapinv nid & 31,234 & 0.2679 & 0.1145 & 0 & 0.33 & 0.389 \\
\hline mtr_div_tlo_gtax_tcapfin & 31,234 & 0.2664 & 0.1167 & 0 & 0.33 & 0.389 \\
\hline mtr_div_tlo_gtax_tcapfin_nid & 31,234 & 0.2664 & 0.1167 & 0 & 0.33 & 0.389 \\
\hline \multicolumn{7}{|l|}{ Simulation year 2006} \\
\hline & $\mathrm{N}$ & Mean & Std dev & Min & Median & Max \\
\hline \multicolumn{7}{|l|}{ Panel A } \\
\hline mtr_tlo & 55,820 & 0.2652 & 0.1119 & 0 & 0.3288 & 0.389 \\
\hline mtr_div_tlo & 55,820 & 0.262 & 0.1137 & 0 & 0.3263 & 0.389 \\
\hline mtr div tlo tcapinv & 55,820 & 0.262 & 0.1137 & 0 & 0.3263 & 0.389 \\
\hline mtr_div_tlo_tcapinv_nid & 55,820 & 0.262 & 0.1137 & 0 & 0.3263 & 0.389 \\
\hline mtr_div_tlo_tcapfin & 55,820 & 0.2602 & 0.1161 & 0 & 0.3261 & 0.389 \\
\hline mtr_div_tlo_tcapfin_nid & 55,820 & 0.2602 & 0.1161 & 0 & 0.3261 & 0.389 \\
\hline \multicolumn{7}{|l|}{ Panel B } \\
\hline mtr_tlo_gtax & 33,939 & 0.2695 & 0.1114 & 0 & 0.332 & 0.389 \\
\hline mtr_div_tlo_gtax & 33,939 & 0.266 & 0.1137 & 0 & 0.33 & 0.389 \\
\hline mtr_div_tlo_gtax_tcapinv & 33,939 & 0.2664 & 0.1131 & 0 & 0.33 & 0.389 \\
\hline mtr_div_tlo_gtax_tcapinv_nid & 33,939 & 0.2664 & 0.1131 & 0 & 0.33 & 0.389 \\
\hline mtr_div_tlo_gtax_tcapfin & 33,939 & 0.2648 & 0.1155 & 0 & 0.33 & 0.389 \\
\hline mtr_div_tlo_gtax_tcapfin_nid & 33,939 & 0.2648 & 0.1155 & 0 & 0.33 & 0.389 \\
\hline
\end{tabular}


Table D.4: Summary statistics by simulation year (continued)

\begin{tabular}{|c|c|c|c|c|c|c|}
\hline Simulation year 2007 & $\mathrm{~N}$ & Mean & Std dev & Min & Median & $\operatorname{Max}$ \\
\hline \multicolumn{7}{|l|}{ Panel A } \\
\hline $\begin{array}{l}\text { mtr_tlo } \\
\text { mtr_div_tlo } \\
\text { mtr_div_tlo_tcapinv } \\
\text { mtr_div_tlo_tcapinv_nid } \\
\text { mtr_div_tlo_tcapfin } \\
\text { mtr_div_tlo_tcapfin_nid }\end{array}$ & $\begin{array}{l}61,810 \\
61,810 \\
61,810 \\
61,810 \\
61,810 \\
61,810 \\
\end{array}$ & $\begin{array}{l}0.26 \\
0.2568 \\
0.2569 \\
0.2538 \\
0.2472 \\
0.2441 \\
\end{array}$ & $\begin{array}{l}0.1082 \\
0.11 \\
0.11 \\
0.1122 \\
0.118 \\
0.1198 \\
\end{array}$ & $\begin{array}{l}0 \\
0 \\
0 \\
0 \\
0 \\
0\end{array}$ & $\begin{array}{l}0.3194 \\
0.3152 \\
0.3154 \\
0.3117 \\
0.3039 \\
0.2961 \\
\end{array}$ & $\begin{array}{l}0.389 \\
0.389 \\
0.389 \\
0.389 \\
0.389 \\
0.389 \\
\end{array}$ \\
\hline \multicolumn{7}{|l|}{ Panel B } \\
\hline $\begin{array}{l}\text { mtr_tlo_gtax } \\
\text { mtr_div_tlo_gtax } \\
\text { mtr_div_tlo_gtax_tcapinv } \\
\text { mtr_div_tlo_gtax_tcapinv_nid } \\
\text { mtr_div_tlo_gtax_tcapfin_ } \\
\text { mtr_div_tlo_gtax_tcapfin_nid }\end{array}$ & $\begin{array}{l}37,840 \\
37,840 \\
37,840 \\
37,840 \\
37,840 \\
37,840\end{array}$ & $\begin{array}{l}0.2639 \\
0.2604 \\
0.2586 \\
0.2536 \\
0.2528 \\
0.2477\end{array}$ & $\begin{array}{l}0.1077 \\
0.1099 \\
0.1105 \\
0.1142 \\
0.1165 \\
0.1197\end{array}$ & $\begin{array}{l}0 \\
0 \\
0 \\
0 \\
0 \\
0\end{array}$ & $\begin{array}{l}0.3248 \\
0.3244 \\
0.3237 \\
0.3221 \\
0.323 \\
0.3205 \\
\end{array}$ & $\begin{array}{l}0.389 \\
0.389 \\
0.389 \\
0.389 \\
0.389 \\
0.389\end{array}$ \\
\hline \multicolumn{7}{|l|}{ Simulation year 2008} \\
\hline \multicolumn{7}{|l|}{ Panel A } \\
\hline $\begin{array}{l}\text { mtr_tlo } \\
\text { mtr_div_tlo } \\
\text { mtr_div_tlo_tcapinv } \\
\text { mtr_div_tlo_tcapinv_nid } \\
\text { mtr_div_tlo_tcapfin } \\
\text { mtr_div_tlo_tcapfin_nid }\end{array}$ & $\begin{array}{l}67,955 \\
67,955 \\
67,955 \\
67,955 \\
67,955 \\
67,955\end{array}$ & $\begin{array}{l}0.2504 \\
0.2473 \\
0.2448 \\
0.2416 \\
0.2278 \\
0.2247\end{array}$ & $\begin{array}{l}0.1002 \\
0.102 \\
0.1013 \\
0.1034 \\
0.1175 \\
0.1189\end{array}$ & $\begin{array}{l}0 \\
0 \\
0 \\
0 \\
0 \\
0\end{array}$ & $\begin{array}{l}0.2769 \\
0.275 \\
0.275 \\
0.275 \\
0.275 \\
0.275\end{array}$ & $\begin{array}{l}0.3554 \\
0.3554 \\
0.3554 \\
0.3554 \\
0.3554 \\
0.3554\end{array}$ \\
\hline \multicolumn{7}{|l|}{ Panel B } \\
\hline $\begin{array}{l}\text { mtr_tlo_gtax } \\
\text { mtr_div_tlo_gtax } \\
\text { mtr_div_tlo_gtax_tcapinv } \\
\text { mtr_div_tlo_gtax_tcapinv_nid } \\
\text { mtr_div_tlo_gtax_tcapfin_ } \\
\text { mtr_div_tlo_gtax_tcapfin_nid }\end{array}$ & $\begin{array}{l}42,065 \\
42,065 \\
42,065 \\
42,065 \\
42,065 \\
42,065 \\
\end{array}$ & $\begin{array}{l}0.2546 \\
0.2513 \\
0.2481 \\
0.243 \\
0.2441 \\
0.239 \\
\end{array}$ & $\begin{array}{l}0.1015 \\
0.1036 \\
0.1037 \\
0.1071 \\
0.1099 \\
0.1129 \\
\end{array}$ & $\begin{array}{l}0 \\
0 \\
0 \\
0 \\
0 \\
0 \\
\end{array}$ & $\begin{array}{l}0.2864 \\
0.28 \\
0.28 \\
0.2787 \\
0.28 \\
0.2775 \\
\end{array}$ & $\begin{array}{l}0.3554 \\
0.3554 \\
0.3554 \\
0.3554 \\
0.3554 \\
0.3554 \\
\end{array}$ \\
\hline \multicolumn{7}{|l|}{ Simulation year 2009} \\
\hline \multicolumn{7}{|l|}{ Panel A } \\
\hline $\begin{array}{l}\text { mtr_tlo } \\
\text { mtr_div_tlo } \\
\text { mtr_div_tlo_tcapinv } \\
\text { mtr_div_tlo_tcapinv_nid } \\
\text { mtr_div_tlo_tcapfin } \\
\text { mtr_div_tlo_tcapfin_nid }\end{array}$ & $\begin{array}{l}85,794 \\
85,794 \\
85,794 \\
85,794 \\
85,794 \\
85,794 \\
\end{array}$ & $\begin{array}{l}0.2384 \\
0.2343 \\
0.232 \\
0.2282 \\
0.211 \\
0.2072 \\
\end{array}$ & $\begin{array}{l}0.1043 \\
0.1063 \\
0.1044 \\
0.1065 \\
0.1215 \\
0.1226 \\
\end{array}$ & $\begin{array}{l}0 \\
0 \\
0 \\
0 \\
0 \\
0 \\
\end{array}$ & $\begin{array}{l}0.2677 \\
0.265 \\
0.2629 \\
0.2623 \\
0.26 \\
0.2579 \\
\end{array}$ & $\begin{array}{l}0.3554 \\
0.3554 \\
0.3554 \\
0.3554 \\
0.3554 \\
0.3554 \\
\end{array}$ \\
\hline \multicolumn{7}{|l|}{ Panel B } \\
\hline $\begin{array}{l}\text { mtr_tlo_gtax } \\
\text { mtr_div_tlo_gtax } \\
\text { mtr_div_tlo_gtax_tcapinv } \\
\text { mtr_div_tlo_gtax_tcapinv_nid } \\
\text { mtr_div_tlo_gtax_tcapfin } \\
\text { mtr_div_tlo_gtax_tcapfin_nid }\end{array}$ & $\begin{array}{l}55,125 \\
55,125 \\
55,125 \\
55,125 \\
55,125 \\
55,125\end{array}$ & $\begin{array}{l}0.2418 \\
0.2373 \\
0.2321 \\
0.2262 \\
0.2286 \\
0.2227\end{array}$ & $\begin{array}{l}0.1057 \\
0.1083 \\
0.1084 \\
0.1115 \\
0.1142 \\
0.117\end{array}$ & $\begin{array}{l}0 \\
0 \\
0 \\
0 \\
0 \\
0\end{array}$ & $\begin{array}{l}0.2748 \\
0.2739 \\
0.263 \\
0.2613 \\
0.2659 \\
0.263\end{array}$ & $\begin{array}{l}0.3554 \\
0.3554 \\
0.3554 \\
0.3554 \\
0.3554 \\
0.3554\end{array}$ \\
\hline Simulation year 2010 & $\mathrm{~N}$ & Mean & Std dev & Min & Median & $\operatorname{Max}$ \\
\hline \multicolumn{7}{|l|}{ Panel A } \\
\hline $\begin{array}{l}\text { mtr_tlo } \\
\text { mtr_div_tlo } \\
\text { mtr_div_tlo_tcapinv } \\
\text { mtr_div_tlo_tcapinv_nid } \\
\text { mtr_div_tlo_tcapfin_ } \\
\text { mtr_div_tlo_tcapfin_nid }\end{array}$ & $\begin{array}{l}90,992 \\
90,992 \\
90,992 \\
90,992 \\
90,992 \\
90,992 \\
\end{array}$ & $\begin{array}{l}0.2301 \\
0.226 \\
0.2235 \\
0.2199 \\
0.2015 \\
0.1979 \\
\end{array}$ & $\begin{array}{l}0.1073 \\
0.109 \\
0.1071 \\
0.1088 \\
0.1223 \\
0.1231 \\
\end{array}$ & $\begin{array}{l}0 \\
0 \\
0 \\
0 \\
0 \\
0 \\
\end{array}$ & $\begin{array}{l}0.263 \\
0.263 \\
0.258 \\
0.2548 \\
0.25 \\
0.248 \\
\end{array}$ & $\begin{array}{l}0.3554 \\
0.3554 \\
0.3554 \\
0.3554 \\
0.3554 \\
0.3554\end{array}$ \\
\hline \multicolumn{7}{|l|}{ Panel B } \\
\hline $\begin{array}{l}\text { mtr_tlo_gtax } \\
\text { mtr_div_tlo_gtax } \\
\text { mtr_div_tlo_gtax_tcapinv } \\
\text { mtr_div_tlo_gtax_tcapinv_nid } \\
\text { mtr_div_tlo_gtax_tcapfin } \\
\text { mtr_div_tlo_gtax_tcapfin_nid }\end{array}$ & $\begin{array}{l}58,569 \\
58,569 \\
58,569 \\
58,569 \\
58,569 \\
58,569\end{array}$ & $\begin{array}{l}0.2317 \\
0.2271 \\
0.222 \\
0.2164 \\
0.2164 \\
0.2108\end{array}$ & $\begin{array}{l}0.1098 \\
0.1117 \\
0.1115 \\
0.1138 \\
0.1175 \\
0.1194\end{array}$ & $\begin{array}{l}0 \\
0 \\
0 \\
0 \\
0 \\
0\end{array}$ & $\begin{array}{l}0.265 \\
0.263 \\
0.255 \\
0.25 \\
0.2592 \\
0.2542\end{array}$ & $\begin{array}{l}0.3554 \\
0.3554 \\
0.3554 \\
0.3554 \\
0.3554 \\
0.3554\end{array}$ \\
\hline
\end{tabular}


Table D.4: Summary statistics by simulation year (continued)

\begin{tabular}{|c|c|c|c|c|c|c|}
\hline Simulation year 2011 & $\mathrm{~N}$ & Mean & Std dev & Min & Median & $\operatorname{Max}$ \\
\hline \multicolumn{7}{|l|}{ Panel A } \\
\hline $\begin{array}{l}\text { mtr_tlo } \\
\text { mtr_div_tlo } \\
\text { mtr_div_tlo_tcapinv } \\
\text { mtr_div_tlo_tcapinv_nid } \\
\text { mtr_div_tlo_tcapfin } \\
\text { mtr_div_tlo_tcapfin_nid }\end{array}$ & $\begin{array}{l}102,533 \\
102,533 \\
102,533 \\
102,533 \\
102,533 \\
102,533 \\
\end{array}$ & $\begin{array}{l}0.219 \\
0.2154 \\
0.2131 \\
0.21 \\
0.195 \\
0.1919 \\
\end{array}$ & $\begin{array}{l}0.1088 \\
0.1101 \\
0.1082 \\
0.1094 \\
0.1204 \\
0.1209 \\
\end{array}$ & $\begin{array}{l}0 \\
0 \\
0 \\
0 \\
0 \\
0\end{array}$ & $\begin{array}{l}0.26 \\
0.2569 \\
0.2383 \\
0.2304 \\
0.2207 \\
0.2179 \\
\end{array}$ & $\begin{array}{l}0.3554 \\
0.3554 \\
0.3554 \\
0.3554 \\
0.3554 \\
0.3554 \\
\end{array}$ \\
\hline \multicolumn{7}{|l|}{ Panel B } \\
\hline $\begin{array}{l}\text { mtr_tlo_gtax } \\
\text { mtr_div_tlo_gtax } \\
\text { mtr_div_tlo_gtax_tcapinv } \\
\text { mtr_div_tlo_gtax_tcapinv_nid } \\
\text { mtr_div_tlo_gtax_tcapfin } \\
\text { mtr_div_tlo_gtax_tcapfin_nid }\end{array}$ & $\begin{array}{l}66,561 \\
66,561 \\
66,561 \\
66,561 \\
66,561 \\
66,561 \\
\end{array}$ & $\begin{array}{l}0.2198 \\
0.2155 \\
0.2089 \\
0.2042 \\
0.2074 \\
0.2027 \\
\end{array}$ & $\begin{array}{l}0.1115 \\
0.1133 \\
0.1131 \\
0.1146 \\
0.1172 \\
0.1186 \\
\end{array}$ & $\begin{array}{l}0 \\
0 \\
0 \\
0 \\
0 \\
0\end{array}$ & $\begin{array}{l}0.2542 \\
0.2498 \\
0.2193 \\
0.2135 \\
0.2321 \\
0.2226 \\
\end{array}$ & $\begin{array}{l}0.3554 \\
0.3554 \\
0.3554 \\
0.3554 \\
0.3554 \\
0.3554 \\
\end{array}$ \\
\hline \multicolumn{7}{|l|}{ Simulation year 2012} \\
\hline \multicolumn{7}{|l|}{ Panel A } \\
\hline $\begin{array}{l}\text { mtr_tlo } \\
\text { mtr_div_tlo } \\
\text { mtr_div_tlo_tcapinv } \\
\text { mtr_div_tlo_tcapinv_nid } \\
\text { mtr_div_tlo_tcapfin } \\
\text { mtr_div_tlo_tcapfin_nid }\end{array}$ & $\begin{array}{l}113,271 \\
113,271 \\
113,271 \\
113,271 \\
113,271 \\
113,271 \\
\end{array}$ & $\begin{array}{l}0.2109 \\
0.2074 \\
0.205 \\
0.2018 \\
0.1846 \\
0.1814 \\
\end{array}$ & $\begin{array}{l}0.1118 \\
0.1128 \\
0.1103 \\
0.1114 \\
0.1224 \\
0.1228 \\
\end{array}$ & $\begin{array}{l}0 \\
0 \\
0 \\
0 \\
0 \\
0 \\
\end{array}$ & $\begin{array}{l}0.25 \\
0.248 \\
0.2118 \\
0.2043 \\
0.1999 \\
0.198 \\
\end{array}$ & $\begin{array}{l}0.3554 \\
0.3554 \\
0.3554 \\
0.3554 \\
0.3554 \\
0.3554 \\
\end{array}$ \\
\hline \multicolumn{7}{|l|}{ Panel B } \\
\hline $\begin{array}{l}\text { mtr_tlo_gtax } \\
\text { mtr_div_tlo_gtax } \\
\text { mtr_div_tlo_gtax_tcapinv } \\
\text { mtr_div_tlo_gtax_tcapinv_nid } \\
\text { mtr_div_tlo_gtax_tcapfin } \\
\text { mtr_div_tlo_gtax_tcapfin_nid }\end{array}$ & $\begin{array}{l}74,762 \\
74,762 \\
74,762 \\
74,762 \\
74,762 \\
74,762 \\
\end{array}$ & $\begin{array}{l}0.2115 \\
0.2071 \\
0.202 \\
0.1976 \\
0.1992 \\
0.1948 \\
\end{array}$ & $\begin{array}{l}0.1143 \\
0.1156 \\
0.1141 \\
0.1153 \\
0.1191 \\
0.1202 \\
\end{array}$ & $\begin{array}{l}0 \\
0 \\
0 \\
0 \\
0 \\
0\end{array}$ & $\begin{array}{l}0.2447 \\
0.2359 \\
0.2 \\
0.2 \\
0.2085 \\
0.2\end{array}$ & $\begin{array}{l}0.3554 \\
0.3554 \\
0.3554 \\
0.3554 \\
0.3554 \\
0.3554 \\
\end{array}$ \\
\hline Simulation year 2013 & $\mathrm{~N}$ & Mean & Std dev & Min & Median & Max \\
\hline \multicolumn{7}{|l|}{ Panel A } \\
\hline $\begin{array}{l}\text { mtr_tlo } \\
\text { mtr_div_tlo } \\
\text { mtr_div_tlo_tcapinv } \\
\text { mtr_div_tlo_tcapinv_nid } \\
\text { mtr_div_tlo_tcapfin } \\
\text { mtr_div_tlo_tcapfin_nid }\end{array}$ & $\begin{array}{l}119,531 \\
119,531 \\
119,531 \\
119,531 \\
119,531 \\
119,531 \\
\end{array}$ & $\begin{array}{l}0.2014 \\
0.1981 \\
0.197 \\
0.1933 \\
0.1845 \\
0.1808 \\
\end{array}$ & $\begin{array}{l}0.1132 \\
0.114 \\
0.1125 \\
0.1136 \\
0.1192 \\
0.1198 \\
\end{array}$ & $\begin{array}{l}0 \\
0 \\
0 \\
0 \\
0 \\
0 \\
\end{array}$ & $\begin{array}{l}0.2198 \\
0.2193 \\
0.2136 \\
0.2048 \\
0.2 \\
0.199 \\
\end{array}$ & $\begin{array}{l}0.3554 \\
0.3554 \\
0.3554 \\
0.3554 \\
0.3554 \\
0.3554 \\
\end{array}$ \\
\hline \multicolumn{7}{|l|}{ Panel B } \\
\hline $\begin{array}{l}\text { mtr_tlo_gtax } \\
\text { mtr_div_tlo_gtax } \\
\text { mtr_div_tlo_gtax_tcapinv } \\
\text { mtr_div_tlo_gtax_tcapinv_nid } \\
\text { mtr_div_tlo_gtax_tcapfin } \\
\text { mtr_div_tlo_gtax_tcapfin_nid }\end{array}$ & $\begin{array}{l}79,734 \\
79,734 \\
79,734 \\
79,734 \\
79,734 \\
79,734\end{array}$ & $\begin{array}{l}0.2027 \\
0.1985 \\
0.1946 \\
0.1902 \\
0.1934 \\
0.189\end{array}$ & $\begin{array}{l}0.1162 \\
0.1173 \\
0.1159 \\
0.1169 \\
0.119 \\
0.1198\end{array}$ & $\begin{array}{l}0 \\
0 \\
0 \\
0 \\
0 \\
0\end{array}$ & $\begin{array}{l}0.2151 \\
0.209 \\
0.2 \\
0.1979 \\
0.2 \\
0.1998\end{array}$ & $\begin{array}{l}0.3554 \\
0.3554 \\
0.3554 \\
0.3554 \\
0.3554 \\
0.3554\end{array}$ \\
\hline
\end{tabular}

Notes: The table presents summary statistics for the different versions of simulated marginal tax rates, broken down by simulation year. The variable definitions are reported in Table D.3. The term 'simulation year' refers to the first year of the simulation period. Source: Own calculations.

the exception of simulation year 2010, the same holds true for the median. The additional consideration of the tax treatment of dividend income results, on average, in a reduced marginal tax rate, as indicated by the smaller mean value of $m t r \_d i v \_t l o$. The differences in the mean values of the two proxy variants are in the range of 31 basis points (simulation year 2008) to 44 basis points (simulation year 2003).

The variable mtr_div_tlo_tcapinv further incorporates the effects of interest deductibility limitations. During 2003 and 2007, the mean of this variable is only slightly larger than the 
mean of $m t r \_d i v \_t l o$ (between zero basis points in the 2006 sample and four basis points in the 2003 and 2004 samples), suggesting that interest deductibility limitations have a real impact on corporate tax status only in specific cases. This might reflect that companies anticipate negative tax effects resulting from not being in line with prescribed safe haven debt-to-equity ratios and therefore adjust their leverage accordingly. Another reason may be data limitations. In particular, the lack of micro-level information on inter-company debt financing makes it difficult to properly estimate the amount of non-conforming related-party interest expense. However, suchlike methodological limitations are of minor importance in modelling the effects of interest capping rules since under these provisions it is not distinguished between alternative sources of debt.

From 2008 on, the mean of mtr_div_tlo_tcapinv drops from second to third rank and is even lower than the mean of $m t r \_d i v \_t l o$. These declines are relatively strong and lie between eleven and 25 basis points in 2013 and 2008, respectively. At first glance, it may seem paradoxical that the additional modelling of deductibility restrictions can lead to a downward change in marginal tax rates. In the case under review, this is to be explained by the replacement of traditional thin capitalisation rules by interest capping rules in France and Germany in 2008. The simulated marginal tax rate indicates the change in tax payments resulting from earning an additional euro today. Under interest capping rules that relate to the company's EBITDA in order to determine the portion of (non-)deductible interest expense each additional euro earned raises the interest deduction capacity. Imagine a stylised tax system where interest expenses are deductible up to an amount of $\alpha \times$ EBITDA from the tax base, net tax losses are immediately refunded and a proportional tax rate of $\tau$ is applied on the tax base. Then, the marginal tax rate of a company with interest expense restricted by the application of an interest capping rule equals $\tau \times(1-\alpha)$ because the incremental income increase allows a further $\alpha$ euro of interest expense to reduce the tax base that would otherwise be deemed a non-deductible expense and taxed at the rate of $\tau$.

None of the considered countries provided a notional interest deduction regulation before 2007. Consequently, the mean values of $m t r \_d i v \_t l o \_t c a p i n v \_n i d$ are equal to those of $m t r \_d i v \_t l o \_t c a p i n v$ for simulation years 2003 through 2006. A comparison of these two proxy variants from 2007 on shows that the additional modelling of the notional interest deduction comes along with a further decline in marginal tax rates of between 31 basis points (simulation year 2007) and 38 basis points (simulation year 2009). 
With the exception of interest deductibility limitation rules, taking into consideration additional tax provisions leads to higher standard deviations of the marginal tax rate proxies under scrutiny. Higher standard deviations indicate a higher degree of variation across companies which is generally desirable from an econometric viewpoint. The standard deviations are highest for mtr_div_tlo_tcapfin and mtr_div_tlo_tcapfin_nid which, however, exclusively results from the zeroing of marginal tax rates of companies that are unable to realise (additional) tax benefits from debt financing.

Visual inspection of Panel B reveals, first, that the means of the various marginal tax rate proxies are, with few exceptions, somewhat higher than in Panel A. This may appear surprising as group taxation generally offers the advantage of inter-company tax loss relief. However, it should be remembered that fiscal unity and consolidation regimes imply that marginal tax rates are determined at group level and then uniformly assigned to all group members. Hence, companies with a zero marginal tax rate before group taxation may show a positive (and thus higher) marginal tax rate once the effects of group taxation are taken into account. Second, it turns out that the relative rankings of the differently defined marginal tax rate estimates remain basically unchanged when the effects of group taxation are added to the calculation, while the variables' means deviate more strongly from each other than in Panel A. This holds particularly true for the relation between $m t r \_d i v \_t l o$ and $m t r \_d i v \_t l o \_t c a p i n v$ as of 2007, indicating that the tax statuses of companies belonging to a tax group are relatively more sensitive to interest capping rules than those of non-tax-consolidated entities. This seems plausible since groups of tax-consolidated companies can benefit from further-reaching interest deductibility capacities than would the individual companies if they were not forming a tax group.

Figure D.2 contains six pairs of histograms that graphically summarise the distributions of the different versions of the simulated marginal tax rate over the entire time period from 2003 to 2013. The three pairs of histograms on the left half relate to the full panel of observations (Panel A) and those on the right half relate to the restricted panel of observations (Panel B). Each coordinate system contains two superimposed histograms in order to graphically illustrate how the distribution of simulated marginal tax rates changes when the scope of considered tax rules is extended. In each case, the blue coloured histogram serves for reference purposes and visualises the distribution of a relatively less sophisticated tax rate proxy compared to the red histogram which displays the distribution of a more comprehensive proxy. The exact definitions are given in the legends below the histograms. 
Figure D.2: Distribution of simulated marginal tax rates
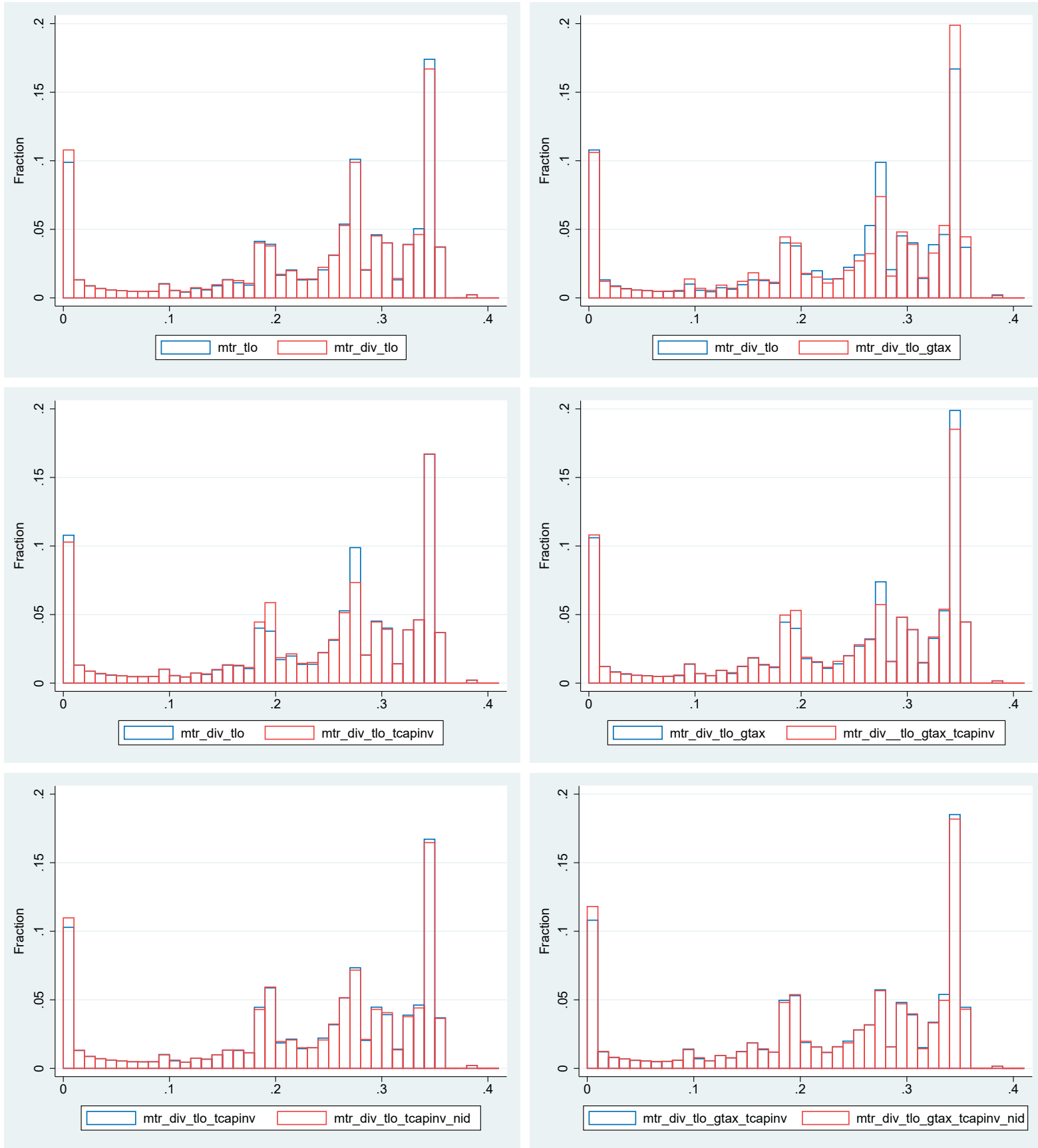

Source: Own figure. Note: The histograms on the left half relate to Panel A and those on the right half relate to Panel B. The histograms show the fractions of simulated marginal tax rates (as defined in the legend) that fall within the respective percentage bin displayed on the horizontal axis. The fractions on the vertical axis refer to the total number of observations, pooled over time. 
Consider first the upper left part of Figure D.2. While the distributions can roughly be described to be U-shaped, they appear less symmetric on closer inspection. To be precise, they are characterised by a relatively large portion of zero marginal tax rates and three peaks of different height which are located around $0.18 / 0.19,0.27$ and 0.34 . The clustering at zero is due to the existence of tax loss carry-forwards. The other three peaks result from an accumulation of company-year observations in specific countries. The highest peak is mainly attributable to the large share of observations from France where the statutory tax rate remained almost constant at 34 to 35 percent throughout the whole investigation period. The lowest peak is driven by observations from various Eastern European countries that applied statutory tax rates just below 20 percent. Finally, the middle peak occurs at around 0.27 . This peak is likely to be affected by the presence of observations from Italy and Spain. This assessment is not only justified by the fact that the statutory tax rates in these countries were predominantly at this level, but it is further reinforced by the observation that the respective histogram bar in the middle left part of Figure D.2 (directly below) decreases when the effects of interest deductibility limitation rules are additionally modelled. By taking as a reference the bluecoloured histogram of $m t r \_t l o$, it appears from the red-coloured histogram that adding the tax treatment of received dividends to the scope of considered tax rules has only little effect on the overall distribution of simulated marginal tax rates. The relieving effects are most evident for companies with relatively high values of $m t r \_t l o$ between 27 and 34 percent. As indicated by the middle left part of Figure D.2, adding interest deductibility limitations to the pool of considered tax rules results in a comparatively strong relative decline of observations with marginal tax rates of around 27 percent and a corresponding relative increase in the share of companies with marginal tax rates of just below 20 percent. At the same time, the relative share of companies with a zero marginal tax rate before the modelling of interest deductibility limitations falls slightly afterwards. The impact of notional interest deduction provisions on the distribution of marginal tax rate estimates is detectable but small. In any case, the lower left part of Figure D.2 reveals that the share of zero marginal tax rate companies increases slightly, reaching again the level prior to the adding of interest deductibility limitations.

In the upper right coordinate system of Figure D.2, I contrast the distributions of $m t r \_d i v \_t l o$ and $m t r \_d i v \_t l o \_g t a x$ in order to scrutinise the influence of group taxation regulations on the distribution of corporate tax status. The graphical representation confirms the findings drawn from the summary statistics in Table D.4, namely that the additional modelling of group taxation 
Table D.5: Pearson correlation matrix

\begin{tabular}{lccccccc}
\hline Panel A $(\mathrm{N}=840,106)$ & & $(1)$ & $(2)$ & $(3)$ & $(4)$ & (5) & (6) \\
\hline mtr_tlo & $(1)$ & 1.000 & & & & & \\
mtr_div_tlo & $(2)$ & 0.986 & 1.000 & & & & \\
mtr_div_tlo_tcapinv & $(3)$ & 0.977 & 0.990 & 1.000 & & & \\
mtr_div_tlo_tcapinv_nid & $(4)$ & 0.951 & 0.967 & 0.976 & 1.000 & & \\
mtr_div_tlo_tcapfin & $(5)$ & 0.860 & 0.872 & 0.896 & 0.872 & 1.000 & \\
mtr_div_tlo_tcapfin_nid & $(6)$ & 0.840 & 0.855 & 0.879 & 0.898 & 0.981 & 1.000 \\
\hline
\end{tabular}

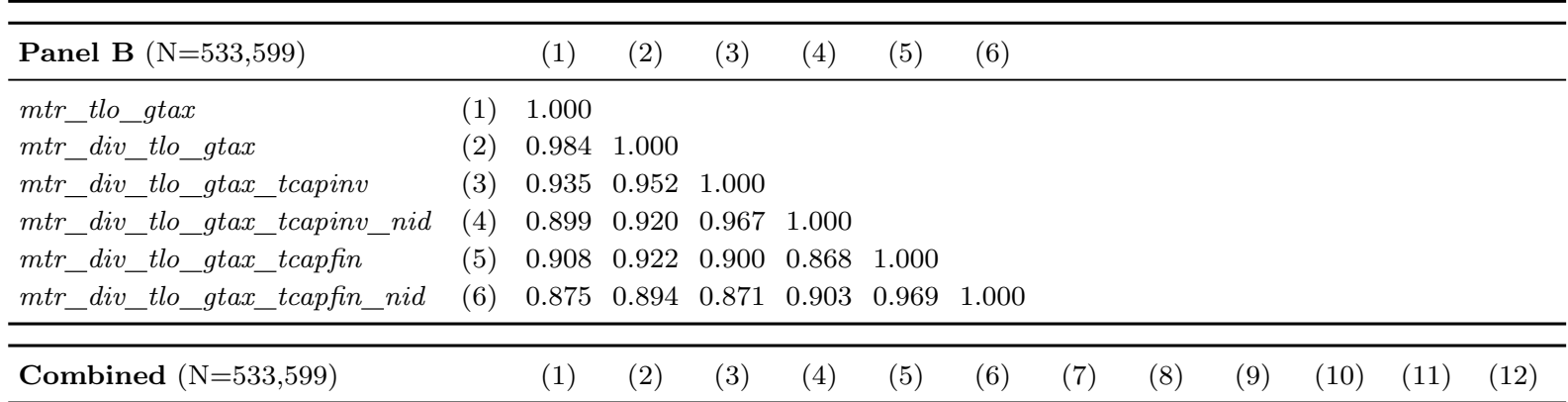

\begin{tabular}{lccccccccccccc}
\hline mtr_tlo & $(1)$ & 1.000 & & & & & & & & & & & \\
mtr_div_tlo & $(2)$ & 0.987 & 1.000 & & & & & & & & & \\
mtr_div_tlo_tcapinv & $(3)$ & 0.981 & 0.994 & 1.000 & & & & & & & & \\
mtr_div_tlo_tcapinv_nid & $(4)$ & 0.943 & 0.961 & 0.967 & 1.000 & & & & & & & & \\
mtr_div_tlo_tcapfin & $(5)$ & 0.896 & 0.908 & 0.923 & 0.889 & 1.000 & & & & & & & \\
mtr_div_tlo_tcapfin_nid & $(6)$ & 0.866 & 0.882 & 0.896 & 0.924 & 0.971 & 1.000 & & & & & & \\
mtr_tlo_gtax & $(7)$ & 0.887 & 0.876 & 0.875 & 0.840 & 0.799 & 0.770 & 1.000 & & & & & \\
mtr_div_tlo_gtax & $(8)$ & 0.876 & 0.886 & 0.884 & 0.854 & 0.808 & 0.784 & 0.984 & 1.000 & & & \\
mtr_div_tlo_gtax_tcapinv & $(9)$ & 0.848 & 0.859 & 0.864 & 0.833 & 0.802 & 0.777 & 0.935 & 0.952 & 1.000 & & \\
mtr_div_tlo_gtax_tcapinv_nid & $(10)$ & 0.812 & 0.828 & 0.832 & 0.867 & 0.770 & 0.806 & 0.899 & 0.920 & 0.967 & 1.000 & \\
mtr_div_tlo_gtax_tcapfin & $(11)$ & 0.816 & 0.826 & 0.828 & 0.798 & 0.874 & 0.848 & 0.908 & 0.922 & 0.900 & 0.868 & 1.000 & \\
mtr_div_tlo_gtax_tcapfin_nid & $(12)$ & 0.783 & 0.798 & 0.800 & 0.832 & 0.844 & 0.877 & 0.875 & 0.894 & 0.871 & 0.903 & 0.969 & 1.000 \\
\hline
\end{tabular}

Notes: The table shows Pearson correlation coefficients between the different variants of simulated marginal tax rates. The variable definitions are reported in Table D.3. The correlation coefficients in the bottom part of the table are evaluated for the restricted sample of companies from Panel B. All coefficients are statistically significant at the 0.1 percent level (two-tailed test). Source: Own calculations.

induces an upward-shift of marginal tax rates. Reasons for this have been discussed above. The middle and lower right parts of Figure D.2 finally show that the additional consideration of interest deductibility limitation rules and notional interest deduction provisions affects the distribution of marginal tax rates in a similar manner, regardless of whether the consequences of group taxation are captured in the simulation or not.

Table D.5 displays Pearson correlation coefficients between the different variants of the simulated marginal tax rate. Though the correlations indicate that the different proxies become more diverge the more tax rules are taken into account, there are still strong linear dependencies among any two of the proxies. Leaving aside the 'tcapfin' variants of the marginal tax rate, mtr_tlo and mtr_div_tlo_tcapinv_nid in Panel $\mathrm{A}$ and $m t r \_t l o \_g t a x$ and $m t r \_d i v \_t l o \_g t a x \_t c a p i n v \_n i d$ in Panel B are most disparate regarding the scope of tax rules modelled. Nevertheless, they 
still show correlation coefficients of 0.951 and 0.899 , respectively. Likewise, there are strong correlations between any proxy variant and the corresponding 'gtax' counterpart. By way of example, the correlation between $m t r \_d i v \_t l o \_t c a p i n v \_n i d$ and $m t r \_d i v \_t l o \_g t a x \_t c a p i n v \_n i d$ is 0.867 .

\subsection{Ability to explain tax status}

The descriptive statistics suggest that the distribution of simulated marginal tax rates is not as sensitive against the additional modelling of the tax treatment of dividend income as expected. There is likewise little change when taking notional interest deduction provisions into consideration. On the other hand, interest deductibility limitations and, in particular, group taxation provisions seem to be of greater significance. But these findings are not indicative about the various simulated tax proxies' capacities to predict actual future corporate tax status. To shed additional light on that issue, in this section I perform empirical tests to examine the relation between corporate tax status as occurred in $t=0$ and any of the simulated marginal tax rate variants.

To measure the tax status that a specific company actually had in any of the simulation years during 2003 and 2013, it would be preferable to employ original tax return data. Unfortunately, unlike Plesko (2003), Graham \& Mills (2008) or Devereux, Maffini \& Xing (2015), I have no access to such data. As a substitute, I calculate GAAP effective tax rates (hereinafter denoted by etr). To this end, I use data on total tax expense and pre-tax book income from unconsolidated financial statements for the financial year corresponding to the simulation year under scrutiny and apply the formula

$$
e t r_{i, 0}=\frac{T A X A_{i, 0}}{P L B T_{i, 0}}
$$

where $T A X A_{i, 0}$ is total tax expense and $P L B T_{i, 0}$ is pre-tax book income of company $i$ in simulation year $t=0$ as reported in Amadeus. Then, I estimate for any marginal tax rate proxy $m t r_{i, 0}$ the simple linear regression through the origin (RTO) model

$$
e t r_{i, 0}=\beta \times m t r_{i, 0}+\epsilon_{i, 0},
$$

where $\epsilon_{i, 0}$ is the residual term. Equation D.40 fits a straight line through the pooled etr versus $m t r$ data that is forced through the origin. Estimating an RTO model without a constant term 
Table D.6: Composition of regression panels

\begin{tabular}{|c|c|c|c|c|}
\hline \multirow[b]{2}{*}{ Country } & \multicolumn{2}{|c|}{ Panel A } & \multicolumn{2}{|c|}{ Panel B } \\
\hline & Obs. & in $\%$ & Obs. & in $\%$ \\
\hline Austria & 1,333 & 0.41 & 789 & 0.36 \\
\hline Belgium & 35,507 & 10.87 & 35,507 & 16.24 \\
\hline Bulgaria & 3,389 & 1.04 & 3,389 & 1.55 \\
\hline Czech Republic & 6,356 & 1.95 & 6,356 & 2.91 \\
\hline Finland & 5,236 & 1.60 & 2,890 & 1.32 \\
\hline France & 100,382 & 30.73 & 69,589 & 31.83 \\
\hline Germany & 9,457 & 2.90 & 4,500 & 2.06 \\
\hline Greece & 3,815 & 1.17 & 3,815 & 1.75 \\
\hline Hungary & 5,588 & 1.71 & 5,588 & 2.56 \\
\hline Ireland & 380 & 0.12 & 380 & 0.17 \\
\hline Italy & 11,562 & 3.54 & 5,112 & 2.34 \\
\hline Latvia & 636 & 0.19 & 636 & 0.29 \\
\hline Lithuania & 574 & 0.18 & 574 & 0.26 \\
\hline Luxembourg & 472 & 0.14 & 304 & 0.14 \\
\hline Malta & 96 & 0.03 & 96 & 0.04 \\
\hline Netherlands & 1,541 & 0.47 & 643 & 0.29 \\
\hline Poland & 6,217 & 1.90 & 3,142 & 1.44 \\
\hline Portugal & 6,841 & 2.09 & 4,158 & 1.90 \\
\hline Romania & 3,856 & 1.18 & 3,856 & 1.76 \\
\hline Slovakia & 155 & 0.05 & 155 & 0.07 \\
\hline Slovenia & 843 & 0.26 & 843 & 0.39 \\
\hline Spain & 71,805 & 21.98 & 43,458 & 19.88 \\
\hline Sweden & 40,455 & 12.38 & 18,509 & 8.47 \\
\hline United Kingdom & 10,154 & 3.11 & 4,324 & 1.98 \\
\hline Total & 326,650 & 100.00 & 218,613 & 100.00 \\
\hline
\end{tabular}

Notes: The table shows the country-wise composition of the observations used in the simple linear regression of Equation D.40. Panels A and B are defined as in Section 5.1 with the exception that only company-years with a non-negative pre-tax book income are included. Source: Own calculations.

is more appropriate than ordinary least squares regression since a company that experiences a zero marginal tax rate generally does not pay any taxes and should also have a zero effective tax rate. Provided that some conditions are met, it may be assumed that the predictive ability of any marginal tax rate proxy is the better the closer $\beta$ is to one. Firstly, in contrast to etr which measures the average tax burden of a company, mtr indicates the tax burden on the last unit of income earned. Though, in general, the two variables measure different things, under a proportional income tax etr may be proportionally linear to $m t r$. This requires, secondly, that etr is sufficiently indicative of the actual tax position, implying that the numerator in Equation D.39 must comprise both current and deferred taxes. If a deferred tax expense (benefit) was not recognised in the numerator, etr would be calculated to be lower (higher) than mtr. Thirdly, a linear relation between etr and $m t r$ just holds if there are no permanent differences between book and tax income. In the presence of non-deductible expenses (non-taxable earnings) taxable income will differ from the denominator in Equation D.39 and a company's etr will tend to be higher (lower) than its mtr.

From the total of 840,106 observations in Panel A, 136,407 company-years have insufficient 
Table D.7: Summary statistics for regression variables

\begin{tabular}{lllllll}
\hline Panel A & N & Mean & Std dev & Min & Median & Max \\
\hline etr & 326,650 & 0.1818 & 0.1202 & 0 & 0.2079 & 0.397 \\
str & 326,650 & 0.3051 & 0.0525 & 0.1 & 0.325 & 0.4022 \\
dich & 326,650 & 0.264 & 0.1176 & 0 & 0.3 & 0.4022 \\
trich & 326,650 & 0.2692 & 0.1087 & 0 & 0.3 & 0.4022 \\
mtr_tlo & 326,650 & 0.2689 & 0.0982 & 0 & 0.3 & 0.4022 \\
mtr_div_tlo & 326,650 & 0.265 & 0.1008 & 0 & 0.3 & 0.4022 \\
mtr_div_tlo_tcapinv & 326,650 & 0.2645 & 0.1006 & 0 & 0.3 & 0.4022 \\
mtr_div_tlo_tcapinv_nid & 326,650 & 0.2602 & 0.1044 & 0 & 0.2993 & 0.4022 \\
\hline Panel B & $\mathrm{N}$ & Mean & Std dev & Min & Median & Max \\
\hline etr & 218,613 & 0.1803 & 0.1234 & 0 & 0.2051 & 0.3889 \\
str & 218,613 & 0.3053 & 0.0572 & 0.1 & 0.3399 & 0.4022 \\
dich & 218,613 & 0.2625 & 0.1211 & 0 & 0.325 & 0.4022 \\
trich & 218,613 & 0.2675 & 0.1129 & 0 & 0.325 & 0.4022 \\
mtr_tlo_gtax & 218,613 & 0.2703 & 0.1012 & 0 & 0.3142 & 0.4022 \\
mtr_div_tlo_gtax & 218,613 & 0.2661 & 0.1041 & 0 & 0.3017 & 0.4022 \\
mtr_div_tlo_gtax_tcapinv & 218,613 & 0.2611 & 0.1076 & 0 & 0.3 & 0.4022 \\
mtr_div_tlo_gtax_tcapinv_nid & 218,613 & 0.2548 & 0.1124 & 0 & 0.3 & 0.4022 \\
\hline
\end{tabular}

Notes: The table provides summary statistics for the variables used in the simple linear regression of Equation D.40. Panels A and B are defined as in Section 5.1 with the exception that only company-years with a non-negative pre-tax book income are included. etr is the GAAP effective tax rate as defined in Equation D.39, restricted to lie between zero and the top statutory corporate income tax rate (denoted by $s t r$ ). dich is a dichotomous tax rate (equal to str for company-years without past carry-forward losses and zero otherwise). trich is a trichotomous tax rate (equal to str for company-years with positive taxable income before loss offset and lacking past carry-forward losses, equal to $0.5 \times s t r$ for company-years with either negative or zero taxable income before loss offset or past carry-forward losses, and equal to zero otherwise. The definitions of the simulated marginal tax rate proxies are given in Table D.3. Source: Own calculations.

data to calculate of etr. Among the remaining 703,699 observations there are 51,572 companyyears with a negative etr that are not considered in the analysis. Since the marginal tax rate is always non-negative, Equation D.40 is effectively not defined for negative values of etr. A further 260,944 company-years are excluded as they exhibit an etr that is higher than the statutory tax rate. This is often due to the existence of expenses that are non-deductible for tax purposes. If those observations were included in the analysis this would impair the interpretability of $\beta$ in Equation D.40 because the marginal tax rate does never exceed the statutory tax rate. Finally, I remove 64,533 observations with negative pre-tax income in simulation year $t=0$ because in those cases the discounting of tax payments under the simulation approach may imply the etr and $m$ tr to drift apart. ${ }^{24}$

This sample selection leaves me with a dataset of 326,650 company-year observations in Panel A and 218,613 observations in Panel B. Table D.6 presents the country composition of the dataset. French and Spanish observations account in both panels for half of the total number

$\overline{24}$ Imagine a simple setting where a company reports a book income of $€-100$ in $t=0$ and a book income of $€ 200$ in $t=1$. The proportional corporate income tax rate is $15 \%$ and the discount interest rate is $6 \%$. In $t=0$, the company pays no taxes but recognises a deferred tax benefit for the loss carry-forward, resulting in a reported total tax expense of $€-15$. Hence, its etr in $t=0$ is $-15 /-100=0.15$. By contrast, the $m t r$ is only $0.15 / 1.06=0.1415$ because the incremental $€ 1$ becomes taxable only in $t=1$. Obviously, the difference between the two measures becomes the larger the later the loss in $t=0$ can be offset against future profits. 
of observations and a further one-fourth of observations is attributable to company-years from Belgium and Sweden.

Besides the different simulated marginal tax rate variants I use for reference purposes three much more simple proxies for a company's marginal tax rate. Namely, I estimate values of $\beta$ also for the top statutory tax rate (denoted by str), a dichotomous tax rate as proposed by Shevlin (1990) and a trichotomous tax rate as in Graham (1996b). The dichotomous tax rate is denoted by dich and equals the top statutory tax rate for companies that have no carry-forward losses from previous years, whereas it is zero for companies which have tax losses from the past available to offset against taxable profits in $t=0$. The trichotomous variable (denoted by trich) can assume three values. It is equal to the top statutory tax rate for companies with positive taxable income before loss offset in $t=0$ that have no past tax losses to carry-over; it is equal to half the top statutory tax rate for companies that have either a negative or zero taxable income before loss offset or a carry-forward loss form prior years in $t=0$; finally, it is set to zero in all other cases. Table D.7 provides summary statistics for the variables used in the simple linear regression. Pearson correlations between the variables are displayed in Table D.8.

Table D.7 reveals that in both panels the mean and median values of etr are almost ten percentage points smaller than those of the explanatory variables. In respect of the explanatory variables, it is conspicuous that the naïve proxies dich and trich exhibit broadly similar location and dispersion parameters as the simulated marginal tax rates. From Table D.8 it appears that there are, in addition, only few differences regarding the correlation of the etr with the tax status proxies, suggesting that the information content about future corporate tax status is quite similar across the various proxies.

The results of the simple linear regression are shown in Table D.9. Comparison of both the beta coefficients and R-squared values for the full Panel A indicates that a refined measurement of marginal tax rates actually results in a better approximation of corporate tax status. Using the str beta estimate as a reference, both the dichotomous and trichotomous tax rates enter the regression with an almost nine percentage points higher coefficient. Regarding the different marginal tax rate variants, the corresponding increase is 10.8 percent for $m t r \_t l o$ and 13.8 percent for mtr_div_tlo_tcapinv_nid. Likewise, simulated marginal tax rates perform better in explaining the variance in effective tax rates. The R-squared is 0.729 when employing the str as proxy for corporate tax status. It is some 3.7 percent and 4.4 percent higher for the dichotomous and trichotomous tax rate, respectively. The coarsest simulated tax proxy, $m t r \_t l o$, explains 
Table D.8: Pearson correlation matrix of regression variables

\begin{tabular}{|c|c|c|c|c|c|c|c|c|c|}
\hline Panel A $(\mathrm{N}=326,650)$ & & $(1)$ & (2) & (3) & (4) & (5) & (6) & (7) & (8) \\
\hline etr & $(1)$ & 1.000 & & & & & & & \\
\hline str & $(2)$ & 0.342 & 1.000 & & & & & & \\
\hline dich & $(3)$ & 0.479 & 0.480 & 1.000 & & & & & \\
\hline trich & (4) & 0.480 & 0.512 & 0.974 & 1.000 & & & & \\
\hline$m t r \_t l o$ & $(5)$ & 0.484 & 0.555 & 0.843 & 0.862 & 1.000 & & & \\
\hline mtr_div_tlo & $(6)$ & 0.500 & 0.540 & 0.845 & 0.860 & 0.981 & 1.000 & & \\
\hline mtr_div_tlo_tcapinv & $(7)$ & 0.501 & 0.543 & 0.843 & 0.858 & 0.979 & 0.996 & 1.000 & \\
\hline$m t r \_d i v \_t l o \_t c a p i n v \_n i d$ & $(8)$ & 0.516 & 0.497 & 0.800 & 0.812 & 0.922 & 0.947 & 0.950 & 1.000 \\
\hline Panel B $(\mathrm{N}=218,613)$ & & (1) & (2) & (3) & (4) & (5) & $(6)$ & (7) & (8) \\
\hline etr & $(1)$ & 1.000 & & & & & & & \\
\hline str & $(2)$ & 0.344 & 1.000 & & & & & & \\
\hline dich & $(3)$ & 0.497 & 0.494 & 1.000 & & & & & \\
\hline trich & $(4)$ & 0.497 & 0.524 & 0.976 & 1.000 & & & & \\
\hline mtr_tlo_gtax & $(5)$ & 0.481 & 0.606 & 0.777 & 0.796 & 1.000 & & & \\
\hline mtr_div_tlo_gtax & $(6)$ & 0.495 & 0.589 & 0.776 & 0.791 & 0.980 & 1.000 & & \\
\hline mtr_div_tlo_gtax_tcapinv & $(7)$ & 0.479 & 0.537 & 0.728 & 0.742 & 0.912 & 0.933 & 1.000 & \\
\hline mtr_div_tlo_gtax_tcapinv_nid & $(8)$ & 0.502 & 0.481 & 0.679 & 0.689 & 0.845 & 0.875 & 0.937 & 1.000 \\
\hline
\end{tabular}

Notes: The table shows Pearson correlation coefficients between the variables used in the simple linear regression. All coefficients are statistically significant at the 0.1 percent level (two-tailed test). Panels A and B are defined as in Section 5.1 with the exception that only company-years with a non-negative pre-tax book income are included. etr is the GAAP effective tax rate as defined in Equation D.39, restricted to lie between zero and the top statutory corporate income tax rate (denoted by str). dich is a dichotomous tax rate (equal to str for company-years without past carry-forward losses and zero otherwise). trich is a trichotomous tax rate (equal to str for company-years with positive taxable income before loss offset and lacking past carry-forward losses, equal to $0.5 \times s t r$ for company-years with either negative or zero taxable income before loss offset or past carry-forward losses, and equal to zero otherwise. The definitions of the simulated marginal tax rate proxies are given in Table D.3. Source: Own calculations.

roughly 5.1 percent more variation than the str. The 'richest' proxy, mtr_div_tlo_tcapinv_nid, yields a 6.3 percent higher R-squared than the str. Hence, capturing tax law asymmetries via $m t r \_t l o$ explains $0.051 / 0.044=15.9$ percent more variation in actual tax status than does the simpler trichotomous tax rate. Employing the most sophisticated proxy mtr_div_tlo_tcapinv_nid results in a $0.063 / 0.044=43.2$ percent gain in variance explained compared to the trichotomous tax rate. If the comparison is made only among the simulated marginal tax rates and $m t r \_t l o$ is taken as a reference, the additional modelling of the tax treatment of dividend income, interest deductibility limitations and notional interest deductions leads to an increase in variance explained of $0.063 / 0.051=23.5$ percent. Altogether, these findings indicate that modelling the taxation of corporate income in greater detail produces estimates of actual corporate tax status that are significantly more accurate than simulated marginal tax rates that only account for the effects of inter-period loss offset.

The results obtained for the full Panel B in general also display higher beta coefficients and R-squared values for more detailed measures of corporate tax status. However, an important 
Table D.9: Predictive ability of simulated marginal tax rates: Regression results

\begin{tabular}{|c|c|c|c|c|c|c|c|c|c|}
\hline \multicolumn{10}{|l|}{ Panel A } \\
\hline \multirow[t]{2}{*}{ Dependent variable: etr } & \multicolumn{3}{|l|}{$\begin{array}{l}\text { Full panel } \\
\mathrm{N}=326,650\end{array}$} & \multicolumn{3}{|c|}{$\begin{array}{l}\text { DefTaxAcc } \\
\mathrm{N}=154,922\end{array}$} & \multicolumn{3}{|c|}{$\begin{array}{l}\text { DefTaxAcc \& LinTax } \\
\mathrm{N}=68,136\end{array}$} \\
\hline & $\begin{array}{l}\mathrm{N}=326,650 \\
\beta\end{array}$ & Std err & $R^{2}$ & & Std err & $R^{2}$ & & & \\
\hline$s t r$ & $0.601^{* * *}$ & $(0.001)$ & 0.729 & $0.599^{* * *}$ & $(0.001)$ & 0.730 & $0.497 * * *$ & $(0.001)$ & 0.653 \\
\hline dich & $0.655^{* * *}$ & $(0.001)$ & 0.756 & $0.650^{* * *}$ & $(0.001)$ & 0.739 & $0.543^{* * *}$ & $(0.002)$ & 0.626 \\
\hline trich & $0.655^{* * *}$ & $(0.001)$ & 0.761 & $0.650^{* * *}$ & $(0.001)$ & 0.748 & $0.545^{* * *}$ & $(0.002)$ & 0.641 \\
\hline$m t r \_t l o$ & $0.666^{* * *}$ & $(0.001)$ & 0.766 & $0.676^{* * *}$ & $(0.001)$ & 0.754 & $0.548^{* * *}$ & $(0.002)$ & 0.661 \\
\hline$m t r \_d i v \_t l o$ & $0.675^{* * *}$ & $(0.001)$ & 0.770 & $0.685^{* * *}$ & $(0.001)$ & 0.758 & $0.555^{* * *}$ & $(0.002)$ & 0.663 \\
\hline mtr_div_tlo_tcapinv & $0.676^{* * *}$ & $(0.001)$ & 0.771 & $0.689^{* * *}$ & $(0.001)$ & 0.758 & $0.561^{* * *}$ & $(0.002)$ & 0.664 \\
\hline mtr_div_tlo_tcapinv_nid & $0.684^{* * *}$ & $(0.001)$ & 0.775 & $0.693^{* * *}$ & $(0.001)$ & 0.761 & $0.562^{* * *}$ & $(0.002)$ & 0.665 \\
\hline \multicolumn{10}{|l|}{ Panel B } \\
\hline \multirow[t]{3}{*}{ Dependent variable: etr } & \multirow{2}{*}{\multicolumn{3}{|c|}{$\begin{array}{l}\text { Full panel } \\
\mathrm{N}=218,613\end{array}$}} & \multirow{2}{*}{\multicolumn{3}{|c|}{$\begin{array}{l}\text { DefTaxAcc } \\
\mathrm{N}=93,849\end{array}$}} & \multirow{2}{*}{\multicolumn{3}{|c|}{$\begin{array}{l}\text { DefTaxAcc \& LinTax } \\
\mathrm{N}=42,138\end{array}$}} \\
\hline & & & & & & & & & \\
\hline & $\beta$ & Std err & $R^{2}$ & $\beta$ & Std err & $R^{2}$ & $\beta$ & Std err & $R^{2}$ \\
\hline$s t r$ & $0.596^{* * *}$ & $(0.001)$ & 0.717 & $0.595^{* * *}$ & $(0.001)$ & 0.718 & $0.490^{* * *}$ & $(0.002)$ & 0.637 \\
\hline dich & $0.655^{* * *}$ & $(0.001)$ & 0.751 & $0.650^{* * *}$ & $(0.001)$ & 0.734 & $0.538^{* * *}$ & $(0.002)$ & 0.616 \\
\hline trich & $0.654^{* * *}$ & $(0.001)$ & 0.756 & $0.650^{* * *}$ & $(0.001)$ & 0.741 & $0.540^{* * *}$ & $(0.002)$ & 0.630 \\
\hline$m t r \_t l o$ & $0.654^{* * *}$ & $(0.001)$ & 0.760 & $0.673^{* * *}$ & $(0.001)$ & 0.747 & $0.543^{* * *}$ & $(0.002)$ & 0.651 \\
\hline$m t r \_t l o \_g t a x$ & $0.657^{* * *}$ & $(0.001)$ & 0.753 & $0.666^{* * *}$ & $(0.001)$ & 0.744 & $0.545^{* * *}$ & $(0.002)$ & 0.653 \\
\hline$m t r \_d i v \_t l o$ & $0.672^{* * *}$ & $(0.001)$ & 0.765 & $0.683^{* * *}$ & $(0.001)$ & 0.751 & $0.551^{* * *}$ & $(0.002)$ & 0.653 \\
\hline$m t r \_d i v \_t l o \_g t a x$ & $0.665^{* * *}$ & $(0.001)$ & 0.757 & $0.675^{* * *}$ & $(0.001)$ & 0.747 & $0.551^{* * *}$ & $(0.002)$ & 0.654 \\
\hline mtr_div_tlo_tcapinv & $0.672^{* * *}$ & $(0.001)$ & 0.765 & $0.685^{* * *}$ & $(0.001)$ & 0.752 & $0.555^{* * *}$ & $(0.002)$ & 0.655 \\
\hline$m t r \_d i v \_t l o \_g t a x \_t c a p i n v$ & $0.670^{* * *}$ & $(0.001)$ & 0.750 & $0.678^{* * *}$ & $(0.001)$ & 0.748 & $0.557^{* * *}$ & $(0.002)$ & 0.657 \\
\hline mtr_div_tlo_tcapinv_nid & $0.684^{* * *}$ & $(0.001)$ & 0.771 & $0.692^{* * *}$ & $(0.001)$ & 0.756 & $0.556^{* * *}$ & $(0.002)$ & 0.655 \\
\hline mtr_div_tlo_gtax_tcapinv_nid & $0.682^{* * *}$ & $(0.001)$ & 0.756 & $0.684^{* * *}$ & $(0.001)$ & 0.752 & $0.557 * * *$ & $(0.002)$ & 0.657 \\
\hline
\end{tabular}

Notes: The table presents the results from the simple linear regression of Equation D.40. Panels A and B are defined as in Section 5.1 with the exception that only company-years with a non-negative pre-tax book income are included. In the sub-sample denoted by 'DefTaxAcc' I exclude observations where etr is derived from unconsolidated financial statements in which deferred taxes are not recognised. In addition to that restriction, the sub-sample 'DefTaxAcc \& LinTax' contains only observations from country-years where the statutory corporate income tax rate is proportional. Dependent variable is the GAAP effective tax rate as defined in Equation D.39, restricted to lie between zero and the top statutory corporate income tax rate (denoted by str). dich is a dichotomous tax rate (equal to str for company-years without past carry-forward losses and zero otherwise). trich is a trichotomous tax rate (equal to $s t r$ for company-years with positive taxable income before loss offset and lacking past carry-forward losses, equal to $0.5 \times s t r$ for company-years with either negative or zero taxable income before loss offset or past carry-forward losses, and equal to zero otherwise. The definitions of the simulated marginal tax rate proxies are given in Table D.3. Source: Own calculations.

exception is that simulated marginal tax rates which incorporate the consequences of group taxation seem to perform less well than their otherwise equal counterparts in whose determination the effects of group taxation are not taken into account. This is somehow in line with the descriptive findings from Table D.4 according to which the additional consideration of group taxation leads, on average, to an increase in the marginal tax rates' mean values. As already discussed in the previous section this alleged paradox has technical reasons and is due to the fact that under the 'pooling onto parent' approach all members of a tax group are assigned the same simulated marginal tax rate determined at group level. ${ }^{25}$

25 If the regressions are re-run for a restricted sample that contains only observations from Finland, Sweden and the United Kingdom where group relief or group contribution systems applied, the (unreported) beta on 
In order to examine the robustness of these findings, I take up the considerations regarding potential limitations associated with using the GAAP effective tax rate as an indicator for realised tax status. Firstly, I try to address the concern that the AmADEUs item 'TAXA' does not consistently comprise deferred taxes. To this end, I exclude from the full panel all observations from countries where the applicable accounting principles do not allow for a recognition of deferred taxes in the unconsolidated financial statements of companies. Respective information is taken from a comprehensive survey by Nobes (2000). Since there were no updates on that survey since 2000, it may well be that my sample composition is not fully appropriate. With this information in mind, the results from the regressions on the 'DefTaxAcc' sample turn out to yield smaller beta estimates for str, dich and trich, whereas those for the simulated marginal tax rates are somewhat larger than in the full sample. This holds true for Panel A and Panel B and reinforces the suggestion that simulated marginal tax rate are superior in explaining actual tax status compared to simpler proxies. Moreover, the overall impression of the results remains similar when the regression samples are additionally restricted to observations from countries with proportional corporate income tax rates. Although both the coefficients and the R-squared values are substantially smaller than before, the relative rankings of the tax rate proxies do not change.

Finally, the present setting offers the opportunity to inspect whether my reservations against simulated marginal tax rates based on estimates of taxable income can be substantiated empirically. In Section 3.3, I argued that approximating taxable income by adjusting consolidated pre-tax book income for deferred taxes may not be suitable for European companies. The reason given was potential mismeasurement of taxable income due to assuming a too comprehensive consolidation scope for tax purposes and understating the effects of permanent book-tax differences. In addition, I alluded to the fact that using information on deferred taxes recognised for temporary book-tax differences to estimate taxable income results in the latter already reflecting the effects of inter-period tax loss offset. I thus stated that an additional modelling of tax loss carry-over, as is commonly done, has to be considered methodologically incorrect.

To scrutinise this issue, it is necessary to replicate the 'traditional' U.S. approach to simulate marginal tax rates. To this end, I need accounting data from consolidated financial statements that enable me to derive estimates of taxable income. In this respect, a core requirement is that deferred taxes are reported in isolation since otherwise the adjustment method of Equation 
Table D.10: Predictive ability of simulated marginal tax rates based on estimated taxable income: Composition of regression panel

\begin{tabular}{lrr}
\hline Country & Obs. & in $\%$ \\
\hline Austria & 10 & 4.69 \\
Belgium & 25 & 11.74 \\
Finland & 7 & 3.29 \\
France & 28 & 13.15 \\
Germany & 76 & 35.68 \\
Greece & 4 & 1.88 \\
Hungary & 2 & 0.94 \\
Latvia & 2 & 0.94 \\
Poland & 1 & 0.47 \\
Romania & 2 & 0.94 \\
Slovenia & 3 & 1.41 \\
Spain & 19 & 8.92 \\
Sweden & 34 & 15.96 \\
\hline Total & 213 & 100 \\
\hline
\end{tabular}

Notes: The table presents the country-wise composition of company-years used to examine the predictive ability of simulated marginal tax rates based on estimated taxable income. Only company-years with a non-negative pre-tax book income are included. Source: Own calculations.

D.12 could bot be applied. Bureau van Dijk's OrBIS database provides respective data with the necessary degree of detail at least for listed companies. The first year with accessible data is 2006. In order to determine the $\operatorname{AR}(1)$ simulation parameters properly, I need at least four historical observations on scaled taxable income for a given simulation year. As a consequence, I am able to simulate marginal tax rates for the three-year window 2011 to 2013. These proxies are denoted by $m t r \_t l o \_c o n s \_d e f t a x$. Table D.10 shows that a total of 213 company-years are available for the analysis, representing 108 companies.

Table D.11 presents the results from the simple linear regression. Besides the coefficients and R-squared values for the U.S. approach-based simulated marginal tax rate ( $\left.m t r \_t l o \_c o n s \_d e f t a x\right)$, for reference purposes I report also the respective values for str, dich, trich and the different variants of simulated marginal tax rates derived under my approach. With respect to the latter, note that I use those variants which incorporate the effects of group taxation since mtr_tlo_cons_deftax also assumes tax consolidation at the parent company level. While mtr_tlo_cons_deftax enters with a larger beta than the naïve proxies str, dich and trich it exhibits the smallest beta among the simulated marginal tax rates. In respect of tax law provisions covered, $m t r \_t l o \_g t a x$ is the relevant counterpart for the comparison. The almost identical results for beta and R-squared suggest that the two tax proxies are not only similarly related to etr but perform equally well in terms of proportion of variance explained. As the coefficient of mtr_div_tlo_gtax_tcapinv_nid is almost 8.3 percent larger than that of $m t r \_t l o \_c o n s \_d e f t a x$ 
Table D.11: Predictive ability of simulated marginal tax rates based on estimated taxable income: Regression results

\begin{tabular}{llll}
\hline Dependent variable: etr $(\mathrm{N}=213)$ & $\beta$ & Std err & $R^{2}$ \\
\hline mtr_tlo_cons_deftax & $0.470^{* * *}$ & $(0.023)$ & 0.671 \\
str & $0.438^{* * *}$ & $(0.022)$ & 0.659 \\
dich & $0.458^{* * *}$ & $(0.025)$ & 0.595 \\
trich & $0.459^{* * *}$ & $(0.025)$ & 0.602 \\
mtr_tlo_gtax & $0.477^{* * *}$ & $(0.024)$ & 0.672 \\
mtr_div_tlo_gtax & $0.493^{* * *}$ & $(0.025)$ & 0.661 \\
mtr_div_tlo_gtax_tcapinv & $0.495^{* * *}$ & $(0.025)$ & 0.664 \\
mtr_div_tlo_gtax_tcapinv_nid & $0.509^{* * *}$ & $(0.024)$ & 0.670 \\
\hline
\end{tabular}

Notes: The table presents the results from the simple linear regression of Equation D.40. The regression sample includes observations on companies for which sufficient accounting data on deferred taxes was available to calculate an estimate for taxable income according to Equation D.12. Dependent variable is the GAAP effective tax rate as defined in Equation D.39, restricted to lie between zero and the top statutory corporate income tax rate (denoted by str). dich is a dichotomous tax rate (equal to str for company-years without past carry-forward losses and zero otherwise). trich is a trichotomous tax rate (equal to $s t r$ for company-years with positive taxable income before loss offset and lacking past carry-forward losses, equal to $0.5 \times$ str for company-years with either negative or zero taxable income before loss offset or past carry-forward losses, and equal to zero otherwise. mtr_tlo_cons_deftax refers to the simulated marginal tax rate calculated for a projected stream of estimated taxable income based on consolidated accounting data. The definitions of the other simulated marginal tax rate proxies are given in Table D.3. Source: Own calculations.

while R-squared is approximately equal, the results also indicate that an explicit modelling of tax rules on simulated accounting income should be preferred over deriving an estimate of taxable income from adjusting accounting income by deferred taxes. These findings seem to underpin my conceptual ideas but they should not be interpreted with caution given the small sample size.

\section{Conclusion}

A precise measurement of corporate tax incentives is essential in order for researchers to draw accurate inferences from empirical analyses on the tax effects on companies' marginal decisions about investment or capital structure. Initially introduced by Shevlin (1987), the approach to simulate marginal tax rates represents the state-of-the-art method to estimate proxies for corporate tax status. It allows for a micro-level modelling of managers' expectations about the future earnings development of a company under uncertainty. Thanks to its multi-period setup, the approach provides the possibility to explicitly take the effects of inter-period tax loss offset into consideration and defines the marginal tax rate as the change in current and future taxes resulting from an incremental income increase in the current period. Despite the fact that simulated marginal tax rates have proven to exercise a statistically significant influence on corporate financing and investment decisions in previous studies, regression models employing 
simulated marginal tax rates were regularly not found to show higher explanatory power than do models where corporate tax status was captured by simpler tax proxies.

In the course of this paper I prepare a proposal for simulating marginal tax rates in the European context. Building upon findings from the existing literature, I use an autoregressive model of first order to simulate company-specific income patterns. In contrast to the approaches pursued by researchers from the U.S., I do not project streams of estimated taxable income into the future as I find this to be suitable only under very particular circumstances. Given some important institutional differences between the U.S. and European legislation, I instead suggest simulating accounting income first and then carrying out explicit modelling of tax rules. In this respect, in determining marginal tax rates I also take into consideration a broader range of tax law provisions than did previous researchers.

Descriptive analysis documents that the distribution of simulated marginal tax rates derived under my approach is largely robust against the additional modelling of the tax treatment of dividend income and notional interest deduction provisions. By contrast, it is more sensitive against the inclusion of interest deductibility limitation rules and, in particular, group taxation provisions. To test for the ability to explain corporate tax status, I regress an empirical construct for the tax position as actually realised on my differently defined proxies for the marginal tax rate. I find the coarsest variant of the simulated marginal tax rate to explain some 16 percent more variation in actual tax status than does a simpler trichotomous variable which only roughly captures the effects of inter-period tax loss offset. When the simulated marginal tax rate additionally incorporates the tax treatment of dividend income, interest deductibility limitation rules and notional interest deduction provisions, the simple linear regression explains around 43 percent more variance in actual tax status than does the trichotomous reference proxy. Due to the specific technique I apply to determine simulated marginal tax rates under group taxation regimes, I am not able to perform corresponding evaluations for these variants of the simulated marginal tax rate. However, a recent study by Gamm, Heckemeyer \& Koch (2016) shows that using the 'gtax' variants of my simulated marginal tax rates actually increases the explanatory power of their empirical model. Results from an additional analysis substantiate the conjecture that simulated marginal tax rates based on unconsolidated accounting data can be expected to predict actual tax status better than simulated marginal tax rates obtained under the U.S. approach of simulating estimated taxable income derived from consolidated financial statements.

In the absence of detailed information on tax-relevant financial statement data, I was forced 
to make a number of assumptions to derive the income components required for a modelling of tax consequences. Therefore, I performed a series of evaluations to examine the plausibility of the simulated marginal tax rates. The findings indicate that the marginal tax rates obtained under my approach can be considered suitable proxies of corporate tax status. It is left for future research to analyse how much my simulated marginal tax rates can contribute to increase the explanatory power of empirical models used to study tax effects on corporate decisions. 


\section{Appendix}

Table D.12: Implementation of the EU Parent Subsidiary Directive in the EU-27 (excluding Estonia) during $2003-2013$

\begin{tabular}{|c|c|c|}
\hline Country & Year & Method \\
\hline Austria & $2003-2013$ & Exemption \\
\hline Belgium & 2003-2013 & Exemption of $95 \%$ \\
\hline \multirow[t]{3}{*}{ Bulgaria } & $2003-2006$ & Credit with limitation \\
\hline & 2007 & Exemption of $95 \%$ \\
\hline & 2008-2013 & Exemption \\
\hline Cyprus & 2003-2013 & Exemption \\
\hline \multirow[t]{2}{*}{ Czech Republic } & 2003 & Credit with limitation \\
\hline & $2004-2013$ & Exemption \\
\hline Denmark & 2003-2013 & Exemption \\
\hline Finland & 2003-2013 & Exemption \\
\hline France & 2003-2013 & Exemption of $95 \%$ \\
\hline Germany & 2003-2013 & Exemption of $95 \%$ \\
\hline \multirow[t]{2}{*}{ Greece } & $2003-2010$ & Credit with limitation \\
\hline & 2011-2013 & Exemption \\
\hline Hungary & $2003-2013$ & Exemption \\
\hline Ireland & 2003-2013 & Credit with limitation \\
\hline Italy & 2003-2013 & Exemption of $95 \%$ \\
\hline Latvia & 2003-2013 & Exemption \\
\hline Lithuania & 2003-2013 & Exemption \\
\hline Luxembourg & 2003-2013 & Exemption \\
\hline \multirow[t]{2}{*}{ Malta } & 2003-2007 & Credit with limitation \\
\hline & 2008-2013 & Exemption \\
\hline Netherlands & 2003-2013 & Exemption \\
\hline \multirow[t]{2}{*}{ Poland } & $2003-2006$ & Credit with limitation \\
\hline & $2007-2013$ & Exemption \\
\hline Portugal & 2003-2013 & Exemption \\
\hline \multirow[t]{2}{*}{ Romania } & 2003-2006 & Credit with limitation \\
\hline & $2007-2013$ & Exemption \\
\hline Sweden & 2003-2013 & Exemption \\
\hline \multirow[t]{2}{*}{ Slovakia } & 2003 & Credit with limitation \\
\hline & 2004-2013 & Exemption \\
\hline \multirow[t]{2}{*}{ Slovenia } & 2003-2007 & Exemption \\
\hline & 2008-2013 & Exemption of $95 \%$ \\
\hline Spain & 2003-2013 & Exemption \\
\hline \multirow[t]{2}{*}{ United Kingdom } & 2003-2009 & Credit with limitation \\
\hline & 2010-2013 & Exemption \\
\hline
\end{tabular}

Source: IBFD European Tax Handbooks 2003-2013. 
Table D.13: Inter-company loss relief under domestic group taxation systems in the EU-27 (excluding Estonia) during 2003-2013

\begin{tabular}{|c|c|c|c|c|}
\hline Country & Year & Type of regime & Loss offsetting technique & Minimum holding \\
\hline \multirow[t]{2}{*}{ Austria } & 2003-2004 & Fiscal unity & Pooling onto parent & $\geq 75 \%$ \\
\hline & 2005-2013 & Fiscal unity & Pooling onto parent & $>50 \%$ \\
\hline Cyprus $^{(*)}$ & 2003-2013 & Group relief & Loss transfer & $\geq 75 \%$ \\
\hline \multirow[t]{2}{*}{ Denmark } & 2003-2005 & Consolidation & Pooling onto parent & $100 \%$ \\
\hline & $2006-2013$ & Consolidation & Pooling onto parent & $>50 \%$ \\
\hline Finland & 2003-2013 & Group contribution & Profit transfer & $\geq 90 \%$ \\
\hline France & 2003-2013 & Fiscal unity & Pooling onto parent & $\geq 95 \%$ \\
\hline Germany & 2003-2013 & Fiscal unity & Pooling onto parent & $>50 \%$ \\
\hline Ireland $^{(*)}$ & 2003-2013 & Group relief & Loss transfer & $\geq 75 \%$ \\
\hline Italy & 2004-2013 & Consolidation & Pooling onto parent & $>50 \%$ \\
\hline Latvia $^{(*)}$ & 2003-2013 & Group relief & Loss transfer & $\geq 90 \%$ \\
\hline \multirow[t]{2}{*}{ Lithuania $^{(*)}$} & 2004-2009 & Group contribution & Profit transfer & - \\
\hline & $2010-2013$ & Group relief & Loss transfer & $\geq 662 / 3 \%$ \\
\hline Luxembourg & 2003-2013 & Fiscal unity & Pooling onto parent & $\geq 95 \%$ \\
\hline $\operatorname{Malta}^{(*)}$ & 2003-2013 & Group relief & Loss transfer & $\geq 51 \%$ \\
\hline Netherlands & 2003-2013 & Consolidation & Pooling onto parent & $\geq 95 \%$ \\
\hline Poland & 2003-2013 & Fiscal unity & Pooling onto parent & $\geq 95 \%$ \\
\hline Portugal & 2003-2013 & Consolidation & Pooling onto parent & $\geq 90 \%$ \\
\hline Sweden & 2003-2013 & Group contribution & Profit transfer & $>90 \%$ \\
\hline Slovenia $^{(*)}$ & 2003-2006 & Consolidation & Pooling onto parent & $\geq 90 \%$ \\
\hline Spain & 2003-2013 & Consolidation & Pooling onto parent & $\geq 75 \%$ \\
\hline United Kingdom & $2003-2013$ & Group relief & Loss transfer & $\geq 75 \%$ \\
\hline
\end{tabular}

Source: IBFD European Tax Handbooks 2003-2013. (*) Tax group structures are not available. 
Table D.15: Thin capitalisation and interest capping rules in the EU-27 (excluding Estonia) during 2003-2013

\begin{tabular}{|c|c|c|c|c|c|c|}
\hline \multirow[t]{2}{*}{ Country } & \multirow[t]{2}{*}{ Year } & \multicolumn{2}{|l|}{ Debt-to-equity ratio } & \multirow[t]{2}{*}{ Non-deductible expenses } & \multirow[t]{2}{*}{ Interest carry-forward } & \multirow[t]{2}{*}{ Notes } \\
\hline & & Safe haven & Debt & & & \\
\hline \multirow[t]{2}{*}{ Belgium } & $2003-2011$ & $1: 1$ & ID & Interest expense on ID in excess of ratio & & \\
\hline & $2012-2013$ & $5: 1$ & ID & Interest expense on ID in excess of ratio & & \\
\hline \multirow[t]{2}{*}{ Bulgaria } & $2003-2006$ & $\begin{array}{l}2: 1 / \text { (interest revenue }+ \\
0.75 \times \text { EBIT })\end{array}$ & $\mathrm{D}$ & $\begin{array}{l}\text { Interest expense on ID in excess of (interest revenue } \\
+0.75 \times \text { EBIT) }\end{array}$ & & \\
\hline & $2007-2013$ & $\begin{array}{l}3: 1 / \text { (interest revenue }+ \\
0.75 \times \text { EBIT })\end{array}$ & $\mathrm{D}$ & $\begin{array}{l}\text { Interest expense on ID in excess of (interest revenue } \\
+0.75 \times \text { EBIT) }\end{array}$ & 5 years & \\
\hline \multirow[t]{5}{*}{ Czech Republic } & $2003-2006$ & $4: 1\left(6: 1^{*}\right)$ & FD & Interest expense on IFD in excess of ratio & & ${ }^{*}$ Financial services sector \\
\hline & 2007 & $4: 1\left(6: 1^{*}\right)$ & $\mathrm{D}$ & Interest expense on ID in excess of ratio & & * Financial services sector \\
\hline & 2008 & $6: 1$ & $\mathrm{ED}$ & Interest expense on ED in excess of ratio & & \\
\hline & & $2: 1\left(3: 1^{*}\right)$ & ID & Interest expense on ID in excess of ratio & & * Financial services sector \\
\hline & 2009-2013 & $4: 1\left(6: 1^{*}\right)$ & ID & Interest expense on ID in excess of ratio & & * Financial services sector \\
\hline Denmark & 2003-2013 & $4: 1$ & $\mathrm{D}$ & Interest expense on ID in excess of ratio & & \\
\hline \multirow[t]{2}{*}{ France } & $2003-2006$ & $1.5: 1$ & ID & Interest expense on ID in excess of ratio & & \\
\hline & $2007-2013$ & 1.5:1 / 0.25×EBITDA & ID & $\begin{array}{l}\text { Interest expense on ID in excess of } \varnothing \text { bank interest } \\
\text { rate for medium-term loans }+ \text { interest expense on ID } \\
\text { in excess of max(related party interest expense on } \\
1.5 \times \text { equity, } 0.25 \times \text { EBITDA, interest revenue from } \\
\text { related parties) }\end{array}$ & $\infty$; annual reduction by $5 \%$ & N/A if company is unaffiliated \\
\hline \multirow[t]{3}{*}{ Germany } & $2003-2007$ & $1.5: 1$ & ID & Interest expense on ID in excess of ratio & & \\
\hline & $2008-2009$ & $0.3 \times$ EBITDA & & Net interest expense on D in excess of $0.3 \times$ EBITDA & $\infty$ & $\begin{array}{l}\mathrm{N} / \mathrm{A} \text { if net interest expense }< \\
€ 1 \mathrm{~m} \text { or company is unaffiliated }\end{array}$ \\
\hline & $2010-2013$ & $0.3 \times$ EBITDA & & Net interest expense on D in excess of $0.3 \times$ EBITDA & $\infty$ & $\begin{array}{l}\text { N/A if net interest expense }< \\
€ 3 \mathrm{~m} \text { or company is unaffiliated } \\
\text { EBITDA carry-forward: } 5 \text { years }\end{array}$ \\
\hline Greece & $2010-2013$ & $3: 1$ & ID & Interest expense on ID in excess of ratio & & \\
\hline Hungary & $2003-2013$ & $3: 1$ & $\mathrm{D}$ & Interest expense on $\mathrm{D}$ in excess of ratio & & N/A to financial services sector \\
\hline
\end{tabular}


Table D.15: Thin capitalisation and interest capping rules in the EU-27 (excluding Estonia) during 2003-2013 (continued)

\begin{tabular}{|c|c|c|c|c|c|c|}
\hline \multirow[t]{2}{*}{ Country } & \multirow[t]{2}{*}{ Year } & \multicolumn{2}{|l|}{ Debt-to-equity ratio } & \multirow[t]{2}{*}{ Non-deductible expenses } & \multirow[t]{2}{*}{ Interest carry-forward } & \multirow[t]{2}{*}{ Notes } \\
\hline & & Safe haven & Debt & & & \\
\hline \multirow[t]{4}{*}{ Italy } & $2003-2004$ & $5: 1$ & ID & Interest expense on ID in excess of ratio & & $\mathrm{N} / \mathrm{A}$ if sales $<€ 5.165 \mathrm{~m}$ \\
\hline & $2005-2007$ & $4: 1$ & ID & Interest expense on ID in excess of ratio & & $\mathrm{N} / \mathrm{A}$ if sales $<€ 5.165 \mathrm{~m}$ \\
\hline & $2008-2009$ & $0.3 \times$ EBITDA & & Net interest expense on $\mathrm{D}$ in excess of $0.3 \times$ EBITDA & & \\
\hline & $2010-2013$ & $0.3 \times$ EBITDA & & Net interest expense on $\mathrm{D}$ in excess of $0.3 \times$ EBITDA & 5 years & EBITDA carry-forward: $\infty$ \\
\hline Latvia & 2003-2013 & $4: 1$ & ID & Interest expense on ID in excess of ratio & & \\
\hline Lithuania & 2003-2013 & $4: 1$ & $\mathrm{D}$ & Interest expense on ID in excess of ratio & & \\
\hline Netherlands & $2004-2012$ & $3: 1$ & $\mathrm{D}$ & Interest expense on ID in excess of ratio & & \\
\hline Poland & 2003-2013 & $3: 1$ & $\mathrm{D}$ & Interest expense on ID in excess of ratio & & \\
\hline \multirow[t]{2}{*}{ Portugal } & 2003-2012 & $2: 1^{*}$ & IFD & Interest expense on IFD in excess of ratio & & $\begin{array}{l}* \text { Equity in safe haven ratio } \\
\text { refers to foreign-held equity; } \\
\text { since } 2006 \mathrm{~N} / \mathrm{A} \text { to debt from } \\
\text { EU resident related parties }\end{array}$ \\
\hline & 2013 & $\max (0.7 \times \mathrm{EBITDA}, € 3 \mathrm{~m})$ & & $\begin{array}{l}\text { Net interest expense on } D \text { in excess of } \\
\max (0.7 \times \text { EBITDA, } € 3 \mathrm{~m})\end{array}$ & 5 years & \\
\hline \multirow[t]{2}{*}{ Romania } & 2003 & $\begin{array}{l}1: 1 / \text { (interest revenue }+ \\
0.1 \times \text { other income) }\end{array}$ & $\mathrm{D}$ & $\begin{array}{l}\text { Interest expense on D in excess of (interest revenue } \\
+0.1 \times \text { other income) }\end{array}$ & $\infty$ & \\
\hline & $2004-2013$ & $\begin{array}{l}3: 1 / \text { (interest revenue }+ \\
0.1 \times \text { other income })\end{array}$ & $\mathrm{D}$ & $\begin{array}{l}\text { Interest expense on D in excess of (interest revenue } \\
+0.1 \times \text { other income) }\end{array}$ & $\infty$ & \\
\hline Slovakia & 2003 & $4: 1\left(6: 1^{*}\right)$ & ID & Interest expense on ID in excess of ratio & & $*$ Financial services sector \\
\hline Slovenia & 2004-2013 & $4: 1$ & ID & Interest expense on ID in excess of ratio & & \\
\hline \multirow[t]{2}{*}{ Spain } & $2003-2011$ & $3: 1$ & ID & Interest expense on ID in excess of ratio & & \\
\hline & $2012-2013$ & $0.3 \times$ EBITDA & & Net interest expense on D in excess of $0.3 \times$ EBITDA & 18 years & $\mathrm{N} / \mathrm{A}$ if company is unaffiliated \\
\hline United Kingdom & 2003-2004 & $1: 1$ & $\mathrm{D}$ & Interest expense on $\mathrm{D}$ in excess of ratio & & \\
\hline
\end{tabular}

Source: IBFD European Tax Handbooks 2003-2013. Note: D: Total debt; ED: Total external debt from unrelated parties; FD: Total foreign debt from related and unrelated parties situated abroad; ID: Internal debt from related parties; IFD: Internal debt from related parties situated abroad. 
Table D.14: Notional interest deduction regimes in the EU-27 (excluding Estonia) during 2003-2013

\begin{tabular}{|c|c|c|c|c|}
\hline Country & Year & NID rate & Reference equity base & Notes \\
\hline \multirow[t]{7}{*}{ Belgium } & 2007 & $3.442 \%$ & $\begin{array}{l}\text { Adjusted share capital }+ \text { retained } \\
\text { earnings at prior-year end }\end{array}$ & $\begin{array}{l}\text { To be applied before loss-offset; NID } \\
\text { carry-forward: } 7 \text { years; SME are } \\
\text { granted } 50 \text { bp higher NID rate }\end{array}$ \\
\hline & 2008 & $3.781 \%$ & $\begin{array}{l}\text { Adjusted share capital }+ \text { retained } \\
\text { earnings at prior-year end }\end{array}$ & $\begin{array}{l}\text { To be applied before loss-offset; NID } \\
\text { carry-forward: } 7 \text { years; SME are } \\
\text { granted } 50 \text { bp higher NID rate }\end{array}$ \\
\hline & 2009 & $4.307 \%$ & $\begin{array}{l}\text { Adjusted share capital + retained } \\
\text { earnings at prior-year end }\end{array}$ & $\begin{array}{l}\text { To be applied before loss-offset; NID } \\
\text { carry-forward: } 7 \text { years; SME are } \\
\text { granted } 50 \text { bp higher NID rate }\end{array}$ \\
\hline & 2010 & $4.473 \%$ & $\begin{array}{l}\text { Adjusted share capital }+ \text { retained } \\
\text { earnings at prior-year end }\end{array}$ & $\begin{array}{l}\text { To be applied before loss-offset; NID } \\
\text { carry-forward: } 7 \text { years; SME are } \\
\text { granted } 50 \text { bp higher NID rate }\end{array}$ \\
\hline & 2011 & $3.8 \%$ & $\begin{array}{l}\text { Adjusted share capital }+ \text { retained } \\
\text { earnings at prior-year end }\end{array}$ & $\begin{array}{l}\text { To be applied before loss-offset; NID } \\
\text { carry-forward: } 7 \text { years; SME are } \\
\text { granted } 50 \text { bp higher NID rate }\end{array}$ \\
\hline & 2012 & $3.425 \%$ & $\begin{array}{l}\text { Adjusted share capital + retained } \\
\text { earnings at prior-year end }\end{array}$ & $\begin{array}{l}\text { To be applied before loss-offset; NID } \\
\text { carry-forward: } 7 \text { years; SME are } \\
\text { granted } 50 \text { bp higher NID rate }\end{array}$ \\
\hline & 2013 & $3 \%$ & $\begin{array}{l}\text { Adjusted share capital + retained } \\
\text { earnings at prior-year end }\end{array}$ & $\begin{array}{l}\text { To be applied before loss-offset; SME } \\
\text { are granted } 50 \mathrm{bp} \text { higher NID rate }\end{array}$ \\
\hline Italy & $2012-2013$ & $3 \%$ & Adjusted new equity & $\begin{array}{l}\text { To be applied after loss-offset; NID } \\
\text { carry-forward: } \infty\end{array}$ \\
\hline \multirow[t]{4}{*}{ Latvia } & 2010 & $5.05 \%$ & Retained earnings of prior year & To be applied before loss-offset \\
\hline & 2011 & $4.37 \%$ & Retained earnings of prior year & To be applied before loss-offset \\
\hline & 2012 & $3.9 \%$ & Retained earnings of prior year & To be applied before loss-offset \\
\hline & 2013 & $4.48 \%$ & Retained earnings of prior year & To be applied before loss-offset \\
\hline
\end{tabular}

Source: IBFD European Tax Handbooks 2003-2013. 
Table D.16: Inter-period tax loss offset in the EU-27 (excluding Estonia) during 2003-2013

\begin{tabular}{|c|c|c|c|c|c|c|}
\hline \multirow[t]{2}{*}{ Country } & \multicolumn{3}{|c|}{ Loss carry-back } & \multicolumn{3}{|c|}{ Loss carry-forward } \\
\hline & Year & Period & $\begin{array}{l}\text { Maximum } \\
\text { deduction }\end{array}$ & Year & Period & Maximum deduction \\
\hline Austria & & & & $2003-2013$ & $\infty$ & $0.75 \times \mathrm{TI}$ \\
\hline Belgium & & & & $2003-2013$ & $\infty$ & \\
\hline Bulgaria & & & & $2003-2013$ & 5 & \\
\hline Cyprus & & & & $\begin{array}{l}2003-2011 \\
2012-2013\end{array}$ & $\begin{array}{r}\infty \\
5\end{array}$ & \\
\hline Czech Republic & & & & $\begin{array}{l}2003 \\
2004-2013\end{array}$ & $\begin{array}{l}7 \\
5\end{array}$ & \\
\hline Denmark & & & & $\begin{array}{l}2003-2012 \\
2013\end{array}$ & $\begin{array}{l}\infty \\
\infty\end{array}$ & $0.6 \times \mathrm{TI}$ if $\mathrm{TI}>\mathrm{DKK} 7.5 \mathrm{~m}$ \\
\hline Finland & & & & $2003-2013$ & 10 & \\
\hline France & $\begin{array}{l}2003-2010 \\
2011-2013\end{array}$ & $\begin{array}{l}3 \\
1\end{array}$ & $€ 1 \mathrm{~m}$ & $\begin{array}{l}2003 \\
2004-2012 \\
2013\end{array}$ & $\begin{array}{l}5 \\
\infty \\
\infty\end{array}$ & $€ 1 \mathrm{~m}+0.5 \times(\mathrm{TI}-€ 1 \mathrm{~m})$ \\
\hline Germany & $\begin{array}{l}2003-2012 \\
2013\end{array}$ & $\begin{array}{l}1 \\
1\end{array}$ & $\begin{array}{r}€ 511,500 \\
€ 1 \mathrm{~m}\end{array}$ & $\begin{array}{l}2003 \\
2004-2013\end{array}$ & $\begin{array}{l}\infty \\
\infty\end{array}$ & $€ 1 \mathrm{~m}+0.6 \times(\mathrm{TI}-€ 1 \mathrm{~m})$ \\
\hline Greece & & & & $2003-2013$ & 5 & \\
\hline Hungary & & & & $\begin{array}{l}2003 \\
2004-2013\end{array}$ & $\begin{array}{l}5 \\
\infty\end{array}$ & \\
\hline Ireland & $2003-2013$ & 1 & & $2003-2013$ & $\infty$ & \\
\hline Italy & & & & $\begin{array}{l}2003-2010 \\
2011-2013\end{array}$ & $\begin{array}{r}5 \\
\infty\end{array}$ & $0.8 \times \mathrm{TI}$ \\
\hline Latvia & & & & $\begin{array}{l}2003-2007 \\
2008 \\
2009 \\
2010-2011 \\
2012-2013\end{array}$ & $\begin{array}{r}5 \\
6 \\
7 \\
8 \\
\infty\end{array}$ & \\
\hline Lithuania & & & & $\begin{array}{l}2003-2007 \\
2008-2013\end{array}$ & $\begin{array}{l}5 \\
\infty\end{array}$ & \\
\hline Luxembourg & & & & $2003-2013$ & $\infty$ & \\
\hline Malta & & & & $2003-2013$ & $\infty$ & \\
\hline Netherlands & $\begin{array}{l}2003-2006 \\
2007-2013\end{array}$ & $\begin{array}{l}3 \\
1\end{array}$ & & $\begin{array}{l}2003-2006 \\
2007-2013\end{array}$ & $\begin{array}{r}\infty \\
9\end{array}$ & \\
\hline Poland & & & & $2003-2013$ & 5 & $0.5 \times$ stock of carry-forward losses \\
\hline Portugal & & & & $\begin{array}{l}2003-2010 \\
2011 \\
2012-2013\end{array}$ & $\begin{array}{l}6 \\
4 \\
5\end{array}$ & $0.75 \times \mathrm{TI}$ \\
\hline Romania & & & & $\begin{array}{l}2003-2008 \\
2009-2013\end{array}$ & $\begin{array}{l}5 \\
7\end{array}$ & \\
\hline Sweden & & & & $2003-2013$ & $\infty$ & \\
\hline Slovakia & & & & $\begin{array}{l}2003-2009 \\
2010-2013\end{array}$ & $\begin{array}{l}5 \\
7\end{array}$ & \\
\hline Slovenia & & & & $\begin{array}{l}2003-2005 \\
2006 \\
2007-2012 \\
2013\end{array}$ & $\begin{array}{l}5 \\
7 \\
\infty \\
\infty\end{array}$ & $0.5 \times \mathrm{TI}$ \\
\hline Spain & & & & $\begin{array}{l}2003-2010 \\
2011 \\
2012-2013\end{array}$ & $\begin{array}{l}15 \\
15 \\
18\end{array}$ & $\begin{array}{r}0.5 \times \mathrm{TI} \text { if } € 20 \mathrm{~m} \leq \text { sales } \leq € 60 \mathrm{~m} \\
0.25 \times \mathrm{TI} \text { if sales }>€ 60 \mathrm{~m} \\
0.5 \times \mathrm{TI} \text { if } € 20 \mathrm{~m} \leq \text { sales } \leq € 60 \mathrm{~m} \\
0.25 \times \mathrm{TI} \text { if sales }>€ 60 \mathrm{~m}\end{array}$ \\
\hline United Kingdom & $2003-2013$ & 1 & & $2003-2013$ & $\infty$ & \\
\hline
\end{tabular}

Source: IBFD European Tax Handbooks 2003-2013. Note: TI: Taxable income before inter-period loss-offset. 
Table D.17: Statutory corporate income tax rates in the EU-27 (excluding Estonia) during 2003-2013

\begin{tabular}{|c|c|c|c|}
\hline Country & Year & Standard rate & Progressive scale/reduced rates \\
\hline \multirow[t]{2}{*}{ Austria } & $2003-2004$ & $34 \%$ & \\
\hline & $2005-2013$ & $25 \%$ & \\
\hline Belgium & $2003-2013$ & $33.99 \%$ & $\begin{array}{l}24.98 \% \text { on } € 0<T I \leq € 25,000 \text { if } T I \leq € 322,500 \\
31.93 \% \text { on } € 25,000<T I \leq € 90,000 \text { if } T I \leq € 322,500 \\
35.535 \% \text { on } € 90,000<T I \leq € 322,500 \text { if } T I \leq € 322,500\end{array}$ \\
\hline \multirow[t]{4}{*}{ Bulgaria } & 2003 & $23.5 \%$ & \\
\hline & 2004 & $19.5 \%$ & \\
\hline & $2005-2006$ & $15 \%$ & \\
\hline & $2007-2013$ & $10 \%$ & \\
\hline \multirow[t]{2}{*}{ Cyprus } & $2003-2004$ & $15 \%$ & \\
\hline & $2005-2013$ & $10 \%$ & \\
\hline \multirow[t]{7}{*}{ Czech Republic } & 2003 & $31 \%$ & \\
\hline & 2004 & $28 \%$ & \\
\hline & 2005 & $26 \%$ & \\
\hline & $2006-2007$ & $24 \%$ & \\
\hline & 2008 & $21 \%$ & \\
\hline & 2009 & $20 \%$ & \\
\hline & $2010-2013$ & $19 \%$ & \\
\hline \multirow[t]{3}{*}{ Denmark } & $2003-2004$ & $30 \%$ & \\
\hline & $2005-2006$ & $28 \%$ & \\
\hline & $2007-2013$ & $25 \%$ & \\
\hline \multirow[t]{3}{*}{ Finland } & $2003-2004$ & $29 \%$ & \\
\hline & $2005-2011$ & $26 \%$ & \\
\hline & $2012-2013$ & $24.5 \%$ & \\
\hline \multirow[t]{3}{*}{ France } & $2003-2004$ & $35.43 \%$ & \\
\hline & 2005 & $34.95 \%$ & \\
\hline & $2006-2013$ & $34.43 \%$ & \\
\hline \multirow[t]{3}{*}{ Germany } & 2003 & $40.216 \%$ & \\
\hline & $2004-2007$ & $38.900 \%$ & \\
\hline & 2008-2013 & $30.175 \%$ & \\
\hline \multirow[t]{7}{*}{ Greece } & $2003-2004$ & $35 \%$ & \\
\hline & 2005 & $32 \%$ & \\
\hline & 2006 & $29 \%$ & \\
\hline & $2007-2009$ & $25 \%$ & \\
\hline & 2010 & $24 \%$ & \\
\hline & 2011-2012 & $20 \%$ & \\
\hline & 2013 & $26 \%$ & \\
\hline \multirow[t]{5}{*}{ Hungary } & 2003 & $18 \%$ & \\
\hline & 2004-2005 & $16 \%$ & \\
\hline & 2006 & $17.33 \%$ & \\
\hline & $2007-2009$ & $20 \%$ & \\
\hline & 2010-2013 & $19 \%$ & \\
\hline Ireland & $2003-2013$ & $12.5 \%$ & \\
\hline
\end{tabular}


Table D.17: Statutory corporate income tax rates in the EU-27 (excluding Estonia) during 2003-2013 (continued)

\begin{tabular}{|c|c|c|c|}
\hline Country & Year & Standard rate & Progressive scale/reduced rates \\
\hline \multirow[t]{3}{*}{ Italy } & 2003 & $34 \%$ & \\
\hline & $2004-2007$ & $33 \%$ & \\
\hline & $2008-2013$ & $27.5 \%$ & \\
\hline \multirow[t]{2}{*}{ Latvia } & 2003 & $19 \%$ & $15.2 \%$ if max. 25 employees and sales < LVL 200,000 \\
\hline & $2004-2013$ & $15 \%$ & \\
\hline \multirow[t]{6}{*}{ Lithuania } & $2003-2005$ & $15 \%$ & \\
\hline & 2006 & $19 \%$ & \\
\hline & 2007 & $18 \%$ & \\
\hline & 2008 & $15 \%$ & \\
\hline & 2009 & $20 \%$ & \\
\hline & $2010-2013$ & $15 \%$ & \\
\hline \multirow[t]{6}{*}{ Luxembourg } & $2003-2005$ & $30.88 \%$ & $28.3 \%$ if $T I \leq € 15,000$ \\
\hline & $2006-2008$ & $29.63 \%$ & $27.55 \%$ if $T I \leq € 15,000$ \\
\hline & 2009-2010 & $28.59 \%$ & $27.75 \%$ if $T I \leq € 15,000$ \\
\hline & 2011 & $28.8 \%$ & $27.55 \%$ if $T I \leq € 15,000$ \\
\hline & 2012 & $28.8 \%$ & $27.75 \%$ if $T I \leq € 15,000$ \\
\hline & 2013 & $29.22 \%$ & $28.2 \%$ if $T I \leq € 15,000$ \\
\hline Malta & 2003-2013 & $35 \%$ & \\
\hline \multirow[t]{7}{*}{ Netherlands } & $2003-2004$ & $34.5 \%$ & $\begin{array}{l}29 \% \text { on } € 0<T I \leq € 22,689 \\
34.5 \% \text { on } T I>€ 22,689\end{array}$ \\
\hline & 2005 & $31.5 \%$ & $\begin{array}{l}27 \% \text { on } € 0<T I \leq € 22,689 \\
31.5 \% \text { on } T I>€ 22,689\end{array}$ \\
\hline & 2006 & $29.6 \%$ & $\begin{array}{l}25.5 \% \text { on } € 0<T I \leq € 22,689 \\
29.6 \% \text { on } T I>€ 22,689\end{array}$ \\
\hline & 2007 & $25.5 \%$ & $\begin{array}{l}20 \% \text { on } € 0<T I \leq € 25,000 \\
23.5 \% \text { on } € 25,000<T I \leq € 60,000 \\
25.5 \% \text { on } T I>€ 60,000\end{array}$ \\
\hline & 2008 & $25.5 \%$ & $\begin{array}{l}20 \% \text { on } € 0<T I \leq € 60,000 \\
23 \% \text { on } € 60,000<T I \leq € 200,000 \\
25.5 \% \text { on } T I>€ 200,000\end{array}$ \\
\hline & 2009-2010 & $25.5 \%$ & $\begin{array}{l}20 \% \text { on } € 0<T I \leq € 200,000 \\
25.5 \% \text { on } T I>€ 200,000\end{array}$ \\
\hline & $2011-2013$ & $25 \%$ & $\begin{array}{l}20 \% \text { on } € 0<T I \leq € 200,000 \\
25 \% \text { on } T I>€ 200,000\end{array}$ \\
\hline \multirow[t]{2}{*}{ Poland } & 2003 & $27 \%$ & \\
\hline & 2004-2013 & $19 \%$ & \\
\hline \multirow[t]{5}{*}{ Portugal } & 2003 & $33 \%$ & \\
\hline & 2004-2006 & $27.5 \%$ & \\
\hline & $2007-2010$ & $26.5 \%$ & \\
\hline & 2011 & $28.5 \%$ & \\
\hline & 2012-2013 & $31.5 \%$ & \\
\hline \multirow[t]{2}{*}{ Romania } & 2003-2004 & $25 \%$ & \\
\hline & $2005-2013$ & $16 \%$ & \\
\hline \multirow[t]{3}{*}{ Slovakia } & 2003 & $25 \%$ & \\
\hline & 2004-2012 & $19 \%$ & \\
\hline & 2013 & $23 \%$ & \\
\hline
\end{tabular}


Table D.17: Statutory corporate income tax rates in the EU-27 (excluding Estonia) during 2003-2013 (continued)

\begin{tabular}{|c|c|c|c|}
\hline Country & Year & Standard rate & Progressive scale/reduced rates \\
\hline \multirow[t]{7}{*}{ Slovenia } & $2003-2006$ & $25 \%$ & \\
\hline & 2007 & $23 \%$ & \\
\hline & 2008 & $22 \%$ & \\
\hline & 2009 & $21 \%$ & \\
\hline & $2010-2011$ & $20 \%$ & \\
\hline & 2012 & $18 \%$ & \\
\hline & 2013 & $17 \%$ & \\
\hline \multirow[t]{4}{*}{ Spain } & $2003-2006$ & $35 \%$ & $\begin{array}{l}30 \% \text { on } € 0<T I \leq € 90,151 \text { if sales }<€ 5,000,000 \\
35 \% \text { on } T I>€ 90,151 \text { if sales }<€ 5,000,000\end{array}$ \\
\hline & 2007 & $32.5 \%$ & $\begin{array}{l}25 \% \text { on } € 0<T I \leq € 120,202 \text { if sales }<€ 5,000,000 \\
32.5 \% \text { on } T I>€ 120,202 \text { if sales }<€ 5,000,000\end{array}$ \\
\hline & $2008-2010$ & $30 \%$ & $\begin{array}{l}25 \% \text { on } € 0<T I \leq € 120,202 \text { if sales }<€ 5,000,000 \\
32.5 \% \text { on } T I>€ 120,202 \text { if sales }<€ 5,000,000\end{array}$ \\
\hline & $2011-2013$ & $30 \%$ & $\begin{array}{l}25 \% \text { on } € 0<T I \leq € 300,000 \text { if sales }<€ 5,000,000 \\
30 \% \text { on } T I>€ 300,000 \text { if sales }<€ 5,000,000 \\
20 \% \text { if max. } 25 \text { employees and sales }<€ 5,000,000\end{array}$ \\
\hline \multirow[t]{3}{*}{ Sweden } & $2003-2008$ & $28 \%$ & \\
\hline & $2009-2012$ & $26.3 \%$ & \\
\hline & 2013 & $22 \%$ & \\
\hline \multirow[t]{7}{*}{ United Kingdom } & $2003-2005$ & $30 \%$ & $\begin{array}{l}0 \% \text { on } £ 0<T I \leq £ 10,000 \\
23.75 \% \text { on } £ 10,000<T I \leq £ 50,000 \\
19 \% \text { on } £ 50,000<T I \leq £ 300,000 \\
32.75 \% \text { on } £ 300,000<T I \leq £ 1,500,000 \\
30 \% \text { on } T I>£ 1,500,000\end{array}$ \\
\hline & 2006 & $30 \%$ & $\begin{array}{l}19 \% \text { on } £ 0<T I \leq £ 300,000 \\
32.75 \% \text { on } £ 300,000<T I \leq £ 1,500,000 \\
30 \% \text { on } T I>£ 1,500,000\end{array}$ \\
\hline & 2007 & $30 \%$ & $\begin{array}{l}20 \% \text { on } £ 0<T I \leq £ 300,000 \\
32.5 \% \text { on } £ 300,000<T I \leq £ 1,500,000 \\
30 \% \text { on } T I>£ 1,500,000\end{array}$ \\
\hline & $2008-2010$ & $28 \%$ & $\begin{array}{l}21 \% \text { on } £ 0<T I \leq £ 300,000 \\
29.75 \% \text { on } £ 300,000<T I \leq £ 1,500,000 \\
28 \% \text { on } T I>£ 1,500,000\end{array}$ \\
\hline & 2011 & $26 \%$ & $\begin{array}{l}20 \% \text { on } £ 0<T I \leq £ 300,000 \\
27.5 \% \text { on } £ 300,000<T I \leq £ 1,500,000 \\
26 \% \text { on } T I>£ 1,500,000\end{array}$ \\
\hline & 2012 & $24 \%$ & $\begin{array}{l}20 \% \text { on } £ 0<T I \leq £ 300,000 \\
25 \% \text { on } £ 300,000<T I \leq £ 1,500,000 \\
24 \% \text { on } T I>£ 1,500,000\end{array}$ \\
\hline & 2013 & $23 \%$ & $\begin{array}{l}20 \% \text { on } £ 0<T I \leq £ 300,000 \\
23.75 \% \text { on } £ 300,000<T I \leq £ 1,500,000 \\
23 \% \text { on } T I>£ 1,500,000\end{array}$ \\
\hline
\end{tabular}

Source: IBFD European Tax Handbooks 2003-2013. Note: TI: taxable income after inter-period loss-offset. 


\section{Kapitel E}

\section{Zusammenfassung}

Die vorliegende Dissertation umfasst drei Beiträge, in deren Rahmen unterschiedliche Formen von Steuerasymmetrien hinsichtlich ihres Einflusses auf Investitionsentscheidungen untersucht werden. Steuerliche Asymmetrien sind regelmäßig ursächlich für fehlende Steuerneutralität. Die Besteuerung wirkt aneutral, wenn die Vorteilhaftigkeitsbeurteilung eines rationalen Entscheiders hinsichtlich sich gegenseitig ausschließender Handlungsalternativen unter Berücksichtigung von Steuern anders ausfällt als vor Berücksichtigung von Steuern. Steuerwirkungen sind aus einzelwirtschaftlicher Sicht abzulehnen, da sie zusätzliche Planungskosten für die Steuerpflichtigen bedingen und wettbewerbsverzerrend wirken. Aus volkswirtschaftlicher Sicht gefährden Steuerasymmetrien die effiziente Faktorallokation und bergen die Gefahr gesamtwirtschaftlicher Wohlfahrtsverluste.

Motiviert durch einen am 24.2. 2012 vorgelegten Entwurf für eine Neukonzeption der Investmentbesteuerung in Deutschland ${ }^{1}$, werden im ersten Beitrag der Dissertation ( „Zur Diskussion der Besteuerung von Wertpapier-Publikumsfonds in Deutschland") die Wirkungen der geltenden und geplanten nationalen steuerlichen Regelungen auf die relative steuerliche Vorteilhaftigkeit direkter Kapitalanlagen gegenüber indirekten Kapitalanlagen über Investmentfonds analysiert. Die Ausgestaltung des bisherigen Regimes der Fondsbesteuerung zielt darauf ab, dass beide Investitionsalternativen im Ergebnis eine steuerliche Gleichstellung erfahren. Angesichts des dem Reformvorschlag immanenten strukturellen Systemwechsels im Bereich der Investmentbesteuerung wird untersucht, inwieweit dem Postulat steuerlicher Belastungsgleichheit auch nach der Reform Rechnung getragen wird. Die Analyse macht deutlich, dass eine steuerliche Gleichbelastung bereits nach geltendem Recht nicht umfassend eintritt, was auf die steuerlich asymmetri-

1 Der in diesem Beitrag untersuchte Reformentwurf wurde in modifizierter Form inzwischen durch das "Gesetz zur Reform der Investmentbesteuerung“ vom 19.7.2016 (BGBl. I S. 1730) und das „Gesetz zur Umsetzung der Änderungen der EU-Amtshilferichtlinie und von weiteren Maßnahmen gegen Gewinnkürzungen und -verlagerungen" vom 20.12.2016 (BGBl. I S. 3000) verabschiedet. Die neuen Regelungen finden ab dem 1. Januar 2018 Anwendung. 
sche Behandlung von Kapitalerträgen im Privatvermögen einerseits und im Betriebsvermögen andererseits zurückzuführen ist. Aus der mit der Reform einhergehenden Schaffung neuer steuerlicher Anknüpfungspunkte im Bereich der Fondsbesteuerung (zu nennen sind hier insbesondere die Körperschaftsteuerpflicht auf Fondsebene, die Besteuerung von Vorabpauschalen im Fall übermäßiger Thesaurierung und die gegebenenfalls eintretende teilweise Freistellung von Fondserträgen bei Anteilsbesitz im Betriebsvermögen) resultiert ausweislich der Berechnungsergebnisse nicht nur ein weiteres Auseinanderdriften der effektiven Steuerbelastungen von Direktund Fondsanlage. Zusätzlich verstärkt sich der Grad der Asymmetrie hinsichtlich der steuerlichen Behandlung von Erträgen aus Anteilen an ausschüttenden und thesaurierenden Fonds. Schließlich ist unter Steuerplanungsaspekten zu erwarten, dass die erhöhte Komplexität steuerlicher Vorteilhaftigkeitsanalysen zu einem Anstieg der Planungskosten auf Ebene der Steuerpflichtigen führt.

Wenngleich die Ergebnisse der quantitativen Analyse Anlass zu der Vermutung geben, dass es infolge der Reform zu Verhaltensänderungen seitens der Steuerpflichtigen kommt, bleiben künftige empirische Untersuchungen auf diesem Gebiet abzuwarten. Theoretisch erwartbare Zusammenhänge lassen sich in empirischen Studien nicht immer nachweisen. Dies betrifft insbesondere Untersuchungen, die sich der Bedeutung steuerlicher Bemessungsgrundlagenkomponenten für unternehmerisches Verhalten widmen. In dieser Hinsicht indizieren empirische Befunde oftmals eine - verglichen mit dem tariflichen Steuersatz-untergeordnete Entscheidungsrelevanz. Beispielhaft kann der zweite Beitrag der Dissertation ( „Location of intra-EU greenfield FDI: Do tax loss offset restrictions matter?") angeführt werden, in dem der Einfluss der asymmetrischen Besteuerung von Gewinnen und Verlusten auf die unternehmerische Standortwahl untersucht wird. Den Steuerrechtsordnungen der Mitgliedstaaten der Europäischen Union ist gemein, dass sie keinen unmittelbaren vollständigen Verlustausgleich kennen; während Gewinne in der Periode ihres Entstehens zu versteuern sind, wird seitens der Fisken nicht korrespondierend eine sofortige Negativsteuer in Höhe des Produkts aus steuerlichem Verlust und Steuersatz gewährt. Verluste sind stattdessen im Wege des Verlustvortrags und, sofern verfügbar, Verlustrücktrags mit Gewinnen anderer Perioden zu verrechnen. Dabei sind unter Umständen zeitliche und betragsmäßige Beschränkungen zu beachten, die sich im Ländervergleich als sehr heterogen darstellen. Zu erwarten ist, dass diesbezüglich bestehende Unterschiede, insbesondere vor dem Hintegrund einer erhöhten Verlustwahrscheinlichkeit in den ersten Jahren neu gegründeter Unternehmen, von rational handelnden multinationalen Unternehmen in Entscheidungen über 
die Standortwahl von Tochtergesellschaften berücksichtigt werden. Mittels multivariater Analysemethoden werden Mikrodaten zu Tochtergesellschaftsgründungen in der Europäischen Union zwischen 2002 und 2012 ausgewertet. Die Ergebnisse weisen erwartungsgemäß einen statistisch hoch signifikant negativen Einfluss des tariflichen Steuersatzes aus, wobei die identifizierten Wirkungsstärken mit denen früherer Studien korrespondieren. Sie legen darüber hinaus allerdings nahe, dass mögliche steuerliche Nachteile, die aus zeitlichen oder betragsmäßigen Restriktionen im Verlustvortrag resultieren, entgegen den Erwartungen keinen statistisch signifikant negativen Einfluss auf die Wahrscheinlichkeit der Standortwahl haben. Dagegen lassen die Resultate auf eine Anreizwirkung von Verlustrücktragsregimen schließen: Länder, die einen Verlustrücktrag einräumen, weisen im Durchschnitt eine etwa 6 Prozentpunkte höhere Wahrscheinlichkeit der Standortwahl auf als sonst vergleichbare Länder ohne Verlustrücktragsregelung. Dieser Effekt ist statistisch signifikant und robust gegen alternative Modellspezifikationen und Stichprobenzusammensetzungen. Werden die Verlustabzugsvariablen mit Näherungsvariablen interagiert, die die erwartete Exponiertheit gegenüber Verlusten abbilden, ergibt sich kein wesentlich anderes Bild. Der positive Zusammenhang zwischen Wahrscheinlichkeit der Standortwahl und Verlustrücktragsoption stellt sich demnach jedoch nicht ein, wenn das grundsätzliche Risiko der Verlusterzielung als zu groß angenommen wird oder der Zeitraum, über den Anlaufverluste zu erwarten sind, überdurchschnittlich lang ist. Die Ergebnisse des Beitrags fügen sich damit auf ambivalente Weise in die Ergebnisse früherer Studien ein. Sie liefern einerseits zusätzliche Indikationen dafür, dass steuerliche Bemessungsgrundlagenkomponenten zusätzlich zum tariflichen Steuersatz Eingang in unternehmerische Entscheidungskalküle finden, soweit sie hinreichende Relevanz für den Steuerstatus des Unternehmens besitzen (vgl. zum Beispiel Overesch \& Wamser (2009), Vorndamme (2014) und Merlo, Riedel \& Wamser (2015)). Andererseits werden angesichts der offensichtlich mangelnden Antizipation möglicher steuerlicher Nachteile aus restriktiven Verlustvortragsregelungen allerdings auch Befunde bestätigt, wonach Bemessungsgrundlageneffekte gegenüber Steuersatzeffekten unterschätzt werden (vgl. zum Beispiel Buettner \& Ruf (2007), Egger \& Merlo (2011) und Blaufus u.a. (2013)).

Die im zweiten Beitrag gewonnenen Erkenntnisse müssen vor dem Hintergrund der Qualität der angewandten Näherungsvariablen für den Steuerstatus der Unternehmen und deren Exponiertheit gegenüber Verlusten gewürdigt werden. Es besteht insoweit die Möglichkeit, dass Messungenauigkeiten ursächlich dafür sind, dass die theoretisch erwarteten Wirkungszusammenhänge teilweise nicht identifiziert werden können. Wenn auch aus methodischen Gründen 
nicht auf inkrementelle Investitionsentscheidungen wie Standortentscheidungen anwendbar, stellt das aus der US-amerikanischen Literatur (Graham (1996b), Graham \& Kim (2009) und Blouin, Core \& Guay (2010)) stammende Konzept simulierter Grenzsteuersätze grundsätzlich einen Ansatz zur präziseren Erfassung unternehmerischer Steuerstatus dar. Trotz ihrer methodischen Überlegenheit gegenüber alternativen Maßgrößen für die unternehmensindividuelle Steuerbelastung, geht in bisherigen ökonometrischen Studien mit der Verwendung simulierter Grenzsteuersätze regelmäßig allerdings keine signifikante Verbesserung des Erklärungsgehalts der Modelle einher. Aufbauend auf den Erkenntnissen von Koch (2014b), widmet sich der dritte Beitrag der Dissertation ( "The sensitivity of simulated marginal tax rates to specific tax rules") deshalb der Konkretisierung der Vorgehensweise zur Simulation marginaler Steuerbelastungen. Daran anschließend werden für ein Panel europäischer Unternehmen Grenzsteuersätze von unterschiedlicher Differenziertheit ermittelt, die auf ihre Sensitivität gegenüber verschiedenen Komponenten der steuerlichen Bemessungsgrundlage hin untersucht werden. Zur Vermeidung methodischer Inkonsistenzen wird in Abwandlung zu den US-Studien keine Schätzgröße für das steuerpflichtige Einkommen fortgeschrieben. Stattdessen erfolgt eine Projektion handelsrechtlicher Einkommmen in die Zukunft, auf die anschließend schrittweise unterschiedliche steuerliche Vorschriften angewandt werden. Deskriptive Auswertungen der resultierenden Verteilungen über alle Unternehmen hinweg zeigen, dass die unter diesem Ansatz gewonnenen marginalen Steuersätze weitgehend insensitiv gegenüber der Modellierung von Vorschriften über die Freistellung von Beteiligungserträgen und die Abzugsfähigkeit kalkulatorischer Eigenkapitalzinsen sind. Eine große Bedeutung hingegen kommt insoweit neben der Modellierung von Vorschriften zur beschränkten Abzugsfähigkeit von Zinsaufwendungen inbesondere der Erfassung von Gruppenbesteuerungsvorschriften zu. Zur Beurteilung der Güte der unterschiedlich differenzierten Grenzsteuersätze hinsichtlich ihrer Eignung zur Approximation des tatsächlich realisierten Steuerstatus auf Ebene des einzelnen Unternehmens schließt sich eine Durchführung univariater Korrelationsanalysen an. Gemessen an der Veränderung des $R^{2}$, erklärt die einfachste Variante simulierter Grenzsteuersätze, die ausschließlich die Effekte steuerlicher Verlustverrechnung erfasst, circa 16 Prozent mehr Variation im tatsächlichen Steuerstatus als ein trichotomer Steuersatz. Werden zusätzlich die Vorschriften zur Dividendenfreistellung, beschränkten Abzugsfähigkeit von Zinsaufwendungen und zum Abzug kalkulatorischer Eigenkapitalzinsen modelliert, ergibt sich ein etwa 43 Prozent größeres $R^{2}$ als im Fall des trichotomen Steuersatzes. Eine über die Erfassung der asymmetrischen Verlustbehandlung hinausgehende Berücksichtigung weiterer Asymmetrien des Steuer- 
rechts im Rahmen der Ermittlung simulierter Grenzsteuersätze verspricht somit einen Beitrag zur Lösung bestehender Identifikationsprobleme in ökonometrischen Studien. Tatsächlich zeigt eine erste Anwendung durch Gamm, Heckemeyer \& Koch (2016), dass die Verwendung einer umfangreicheren Variante der hier entwickelten Grenzsteuersätze, in der zusätzlich die Effekte der Gruppenbesteuerung reflektiert sind, den Erklärungsgehalt des zugrundeliegenden Modells erhöht. Eine abschließende Analyse des dritten Beitrags der Dissertation liefert überdies Indikationen, dass die aus unkonsolidierten Daten gewonnenen Grenzsteuersätze eine höhere Prognosegüte aufweisen als solche, die unter dem traditionellen US-amerikanischen Ansatz ermittelt werden.

Eine zusammenfassende Betrachtung der Ergebnisse dieser Dissertation hinsichtlich ihrer Aussagefähigkeit zum Einfluss von Steuerasymmetrien auf Investitionsentscheidungen dokumentiert, dass die effektive Steuerbelastung von Investitionen und der Steuerstatus von Unternehmen wesentlich von Bemessungsgrundlageneffekten beeinflusst werden können. Ferner wird deutlich, dass der Erfolg eines entsprechenden empirischen Nachweises wesentlich von der Qualität des in ökonometrischen Untersuchungen angelegten Maßes für den unternehmerischen Steuerstatus abhängt. In dieser Hinsicht zeigen die konzeptionellen Arbeiten des dritten Beitrags Möglichkeiten zur Fortentwicklung der Methode unternehmensspezifischer simulierter Grenzsteuersätze auf. Die Besprechung der Limitationen der drei Studien lässt aus Sicht der empirischen Steuerforschung einen Bedarf nach hinreichend detaillierten Finanzdaten auf Ebene des einzelnen Unternehmens erkennen. Unabhängig davon bleibt es der künftigen Forschung überlassen, Ansätze zur unternehmensindividuellen Ermittlung von Steuerbelastungsgrößen zu entwickeln, die in ökonometrischen Studien eine bessere Erfassung des unternehmerischen Steuerstatus im Zusammenhang mit diskreten Unternehmensentscheidungen — wie der Standortwahl— ermöglichen. 


\section{Literaturverzeichnis}

[Altshuler u. a., 2009] Altshuler, Rosanne, Alan J. Auerbach, Michael Cooper \& Matthew Knittel. Understanding U.S. Corporate Tax Losses. In: Tax Policy and the Economy. Hrsg. von Jeffrey R. Brown \& James M. Poterba. Bd. 23. Chicago Juli 2009, S. 73-122

[Alworth \& Arachi, 2001] Alworth, Julian \& Giampaolo Arachi. The Effect of Taxes on Corporate Financing Decisions: Evidence from a Panel of Italian Firms. In: International Tax and Public Finance 8(4), S. 353-376

[Anonymous, 2012] Anonymous. Notional interest deduction: An innovative Belgian tax incentive. Tax Year 2013-Income 2012. Brussels 2012. Online abrufbar unter: http://www.minfin. fgov . be / portail2 / belinvest/downloads / en/publications / bro_notional_interest.pdf (zuletzt abgerufen am 17.07.2016)

[Arachi \& Biagi, 2005] Arachi, Giampaolo \& Federico Biagi. Taxation, Cost of Capital and Investment: Do Tax Asymmetries Matter? In: Giornale degli economisti e annali di economia $64(2 / 3)$, S. $295-321$

[Bacia, 2007] Bacia, Bartosz. Gruppenbesteuerung in Polen. In: Wirtschaft und Recht in Osteuropa $16(2)$, S. 33-64

[Barlev \& Levy, 1975] Barlev, Benzion \& Haim Levy. Loss Carryback and the Carryover Provision: Effectiveness and Economic Implications. In: National Tax Journal 28(2), S. 173184

[Barrios u. a., 2009] Barrios, Salvador, Harry Huizinga, Luc Laeven \& Gaëtan Nicodème. International Taxation and Multinational Firm Location Decision. Economic Papers 356. Brussels: European Commission 2009 
[Barrios u. a., 2012] Barrios, Salvador, Harry Huizinga, Luc Laeven \& Gaëtan Nicodème. International taxation and multinational firm location decisions. In: Journal of public economics 96 (11), S. 946-958

[BDI/KPMG, 2009] BDI/KPMG. BDI/KPMG-Studie 2009. Die Behandlung von Finanzierungsaufwendungen. Ein Vergleich der Zinsschranke in Deutschland mit den Regelungen in den USA, Italien, Frankreich, den Niederlanden und Schweden. Berlin und Frankfurt/Main 2009. Online abrufbar unter: http:/ / bdi .eu / media / presse / publikationen / marketing / 91707_BDI_Zinsschranke_final.pdf (zuletzt abgerufen am 22.07.2016)

[Berger, 2010] Berger, Hanno. InvStG § 1. In: Investmentgesetz, Investmentsteuergesetz: Kommentar. Hrsg. von Hanno Berger, Kai-Uwe Steck \& Dieter Lü̈̈behüsen. München 2010

[Berger, Steck \& Lübbehüsen, 2010] Berger, Hanno, Kai-Uwe Steck \& Dieter Lübbehüsen (Hrsg.). Investmentgesetz, Investmentsteuergesetz: Kommentar. München 2010

[Binkowski \& Michaliszyn, 2003] Binkowski, Artur \& Arkadiusz Michaliszyn. Polish Business Law. Den Haag 2003

[Blaufus u.a., 2013] Blaufus, Kay, Jonathan Bob, Jochen Hundsdoerfer, Dirk Kiesewetter \& Joachim Weimann. Decision heuristics and tax perception-An analysis of a tax-cut-cumbase-broadening policy. In: Journal of Economic Psychology 35 (1), S. 1-16

[Blonigen, 2005] Blonigen, Bruce A. A Review of the Empirical Literature on FDI Determinants. In: Atlantic Economic Journal 33, S. 383-403

[Blouin, Core \& Guay, 2010] Blouin, Jennifer, John E. Core \& Wayne Guay. Have the tax benefits of debt been overestimated? In: Journal of Financial Economics 98 (2), S. 195-213

[Blundell \& Bond, 1998] Blundell, Richard \& Stephen Bond. Initial conditions and moment restrictions in dynamic panel data models. In: Journal of Econometrics 87 (1), S. 115-143 
[Buch u.a., 2005] Buch, Claudia M., Jörn Kleinert, Alexander Lipponer \& Farid Toubal. Determinants and effects of foreign direct investment: evidence from German firm-level data. In: Economic Policy 20 (41), S. 52-110

[Buettner \& Ruf, 2007] Buettner, Thiess \& Martin Ruf. Tax incentives and the location of FDI: Evidence from a panel of German multinationals. In: International Tax and Public Finance $14(2)$, S. $151-164$

[Buettner \& Wamser, 2009] Buettner, Thiess \& Georg Wamser. The impact of nonprofit taxes on foreign direct investment: evidence from German multinationals. In: International Tax and Public Finance 16 (3), S. 298-320

[BaFin, 2013] Bundesanstalt für Finanzdienstleistungsaufsicht. Richtlinie zur Festlegung von Fondskategorien gemäß $§ 4$ Abs. 2 Kapitalanlagegesetzbuch. Frankfurt am Main/Bonn 22. Juli 2013. Online abrufbar unter: http://www.bafin.de/SharedDocs/Aufsichtsrecht/DE/Richtli nie/rl_130722_fondskategorien.html (zuletzt abgerufen am 13.03.2014)

[BVI, 2013] Bundesverband Investment und Asset Management. Investmentstatistik - Zeitreihe Publikumsfonds, Spezialfonds und Vermögen außerhalb von Investmentfonds von 1950 bis 2012. Frankfurt am Main 2013. Online abrufbar unter: http://www.bvi.de/fileadmin / user_upload/Statistik/Zeitreihe_Statistik_20130411.pdf (zuletzt abgerufen am 06. 09.2013)

[Wirtschaftsverbände, 2012] Bundesvereinigung der deutschen Arbeitgeberverbände e.V., Bundeverband deutscher Banken e.V., Bundeverband der deutschen Industrie e.V., Bundesverband Großhandel, Außenhandel, Dienstleistungen e.V., Deutscher Industrie- und Handelskammertag e.V., Gesamtverband der deutschen Versicherungswirtschaft e.V., Handelsverband Deutschland (HDE) der Einzelhandel e.V., Zentralverband des deutschen Handwerks e.V. Stellungnahme der Wirtschaftsverbände zum Berichtsentwurf zur Neukonzeption der Investmentfondsbesteuerung. Berlin 16. März 2012. Online abrufbar unter: http://www . einzelhandel.de/index.php/themeninhalte/steuern /item/download /3581_6cdcb163401ddb 750e4b8adbf04c8af3.html (zuletzt abgerufen am 13.03.2014) 
[Büttner \& Mücke, 2010] Büttner, John \& Ulf Mücke. InvStG § 8. In: Investmentgesetz, Investmentsteuergesetz: Kommentar. Hrsg. von Hanno Berger, Kai-Uwe Steck \& Dieter Lübbehüsen. München 2010

[Charpentier \& Gelli, 2008] Charpentier, Catherine \& Nadine Gelli. French thin capitalisation rules. Paris Februar 2008. Online abrufbar unter: https://www.ashurst.com/doc.aspx? id_Content=2407 (zuletzt abgerufen am 22.07.2016)

[Collins, Kemsley \& Lang, 1998] Collins, Julie, Deen Kemsley \& Mark Lang. Cross-Jurisdictional Income Shifting and Earnings Valuation. In: Journal of Accounting Research 36 (2), S. 209229

[Deutsche Bundesbank, 2013] Deutsche Bundesbank. Statistisches Beiheft 2. Kapitalmarktstatistik. Frankfurt am Main September 2013. Online abrufbar unter: http://www.bundesbank. de/Redaktion/DE/Downloads/Veroeffentlichungen/Statistische_Beihefte_2/2013/2013_09_ kapitalmarktstatistik.pdf (zuletzt abgerufen am 14.03.2014)

[Deutscher Bundestag, 2003] Deutscher Bundestag. BT-Drucksache 15/1553. Entwurf eines Gesetzes zur Modernisierung des Investmentwesens und zur Besteuerung von Investmentvermögen (Investmentmodernisierungsgesetz). 19.09. 2003. Berlin 2003. Online abrufbar unter: http : / / dipbt. bundestag.de/doc/btd/15/015/1501553.pdf (zuletzt abgerufen am 14.03. 2014)

[Devereux, Elschner u.a., 2008] Devereux, Michael P., Christina Elschner u. a. Project for the EU Commission (TAXUD/2005/ DE/3 10) - Final Report. Mannheim und Oxford 2008

[Devereux \& Griffith, 1998] Devereux, Michael P. \& Rachel Griffith. Taxes and the location of production: evidence from a panel of US multinationals. In: Journal of Public Economics $68(3)$, S. $335-367$

[Devereux \& Griffith, 1999] Devereux, Michael P. \& Rachel Griffith. The taxation of discrete investment choices. Working Paper W98/16. London: The Institute for Fiscal Studies Februar 1999 
[Devereux, Maffini \& Xing, 2015] Devereux, Michael P., Giorgia Maffini \& Jing Xing. Corporate tax incentives and capital structure: empirical evidence from UK tax returns. Working Paper 15/07. Oxford University Centre for Business Taxation Mai 2015

[Dharmapala \& Riedel, 2013] Dharmapala, Dhammika \& Nadine Riedel. Earnings shocks and tax-motivated income-shifting: Evidence from European multinationals. In: Journal of Public Economics 97, S. 95-107

[Dreßler \& Overesch, 2013] Dreßler, Daniel \& Michael Overesch. Investment impact of tax loss treatment-empirical insights from a panel of multinationals. In: International Tax and Public Finance 20 (3), S. 513-543

[Dunning, 1977] Dunning, John H. Trade, Location of Economic Activity and the MNE: A Search for an Eclectic Approach. In: The International Allocation of Economic Activity. Hrsg. von Bertil Ohlin, Per-Ove Hesselborn \& Per Magnus Wijkman. London und Basingstoke 1977, S. $395-418$

[Dunning, 2000] Dunning, John H. The eclectic paradigm as an envelope for economic and business theories of MNE activity. In: International Business Review 9 (2), S. 163-190

[Edgerton, 2010] Edgerton, Jesse. Investment incentives and corporate tax asymmetries. In: Journal of Public Economics 94 (11-12), S. 936-952

[Egger \& Merlo, 2011] Egger, Peter \& Valeria Merlo. Statutory Corporate Tax Rates and Double-Taxation Treaties as Determinants of Multinational Firm Activity. In: FinanzArchiv: Public Finance Analysis 67 (2), S. 145-170

[Endres \& Spengel, 2015] Endres, Dieter \& Christoph Spengel (Hrsg.). International Company Taxation and Tax Planning. Alphen aan den Rijn 2015

[Englisch, 2010] Englisch, Joachim. InvStG § 11. In: Investmentgesetz, Investmentsteuergesetz: Kommentar. Hrsg. von Hanno Berger, Kai-Uwe Steck \& Dieter Lübbehüsen. München 2010 
[ECB, 2016] European Central Bank. Interest rate statistics (2004 EU Member States \& ACCBs). Frankfurt am Main 2016. Online abrufbar unter: http://sdw.ecb.europa.eu/browse. do?node=bbn4864 (zuletzt abgerufen am 09.07.2016)

[Feld \& Heckemeyer, 2011] Feld, Lars P. \& Jost H. Heckemeyer. FDI and Taxation: A MetaStudy. In: Journal of Economic Surveys 25 (2), S. 233-272

[Fischer \& Steck, 2010] Fischer, Carsten \& Kai-Uwe Steck. InvG § 96. In: Investmentgesetz, Investmentsteuergesetz: Kommentar. Hrsg. von Hanno Berger, Kai-Uwe Steck \& Dieter Lübbehüsen. München 2010

[Fraedrich, 2012] Fraedrich, Jessica. Das österreichische Erstattungsverfahren als Gestaltungsoption für die erforderliche Neuregelung der Streubesitzdividendenbesteuerung in Deutschland. In: Internationales Steuerrecht 21 (15), S. 565-572

[Gamm, Heckemeyer \& Koch, 2016] Gamm, Markus, Jost H. Heckemeyer \& Reinald Koch. Profit Shifting and the marginal tax rate: Is there a shift-to-loss effect? Working paper. Katholische Universität Eichstätt-Ingolstadt und Leibniz Universität Hannover 2016

[Graham, 1996] Graham, John R. Debt and the marginal tax rate. In: Journal of Financial Economics 41 (1), S. 41-73

[Graham, 1996] Graham, John R. Proxies for the corporate marginal tax rate. In: Journal of Financial Economics 42 (2), S. 187-221

[Graham, 2000] Graham, John R. How Big Are the Tax Benefits of Debt? In: The Journal of Finance 55 (5), S. 1901-1941

[Graham \& Kim, 2009] Graham, John R. \& Hyunseob Kim. Simulating Corporate Marginal Income Tax Rates and Implications for Corporate Debt Policy. Working Paper. Duke University und NBER November 2009 
[Graham, Lemmon \& Schallheim, 1998] Graham, John R., Michael L. Lemmon \& James S. Schallheim. Debt, Leases, Taxes, and the Endogeneity of Corporate Tax Status. In: The Journal of Finance $53(1)$, S. 131-162

[Graham \& Mills, 2008] Graham, John R. \& Lillian F. Mills. Using tax return data to simulate corporate marginal tax rates. In: Journal of Accounting and Economics 46 (2-3), S. 366-388

[Grubert \& Mutti, 1991] Grubert, Harry \& John Mutti. Taxes, Tariffs and Transfer Pricing in Multinational Corporate Decision Making. In: The Review of Economics and Statistics 73 (2), S. $285-293$

[Hammer, 2013] Hammer, Markus. InvStG § 7. In: Blümich Kommentar: Einkommensteuergesetz, Körperschaftsteuergesetz, Gewerbesteuergesetz. Hrsg. von Bernd Heuermann \& Peter Brandis. München 2013. 116. Ergänzungslieferung (Stand: August 2012)

[Hanlon, 2003] Hanlon, Michelle. What Can We Infer about a Firm's Taxable Income from Its Financial Statements? In: National Tax Journal 56 (4), S. 831-863

[Hanlon \& Heitzman, 2010] Hanlon, Michelle \& Shane Heitzman. A review of tax research. In: Journal of Accounting and Economics 50 (2-3), S. 127-178

[Hartmann-Wendels, Stein \& Stöter, 2012] Hartmann-Wendels, Thomas, Ingrid Stein \& Alwin Stöter. Tax incentives and capital structure choice: evidence from Germany. Discussion Paper 18/2012. Deutsche Bundesbank 2012

[Hebous, Ruf \& Weichenrieder, 2011] Hebous, Shafik, Martin Ruf \& Alfons J. Weichenrieder. The Effects of Taxation on the Location Decision of Multinational Firms: M\&A versus Greenfield Investments. In: National Tax Journal 64 (3), S. 817-838

[Heuermann \& Brandis, 2013] Heuermann, Bernd \& Peter Brandis (Hrsg.). Blümich Kommentar: Einkommensteuergesetz, Körperschaftsteuergesetz, Gewerbesteuergesetz. München 2013 
[Huizinga \& Laeven, 2008] Huizinga, Harry \& Luc Laeven. International profit shifting within multinationals: A multi-country perspective. In: Journal of Public Economics 92 (5-6), S. $1164-1182$

[Jacobs, 1988] Jacobs, Otto H. Unternehmensbesteuerung und Rechtsform. München 1988

[Kammeter, 2012] Kammeter, Roland. Neukonzeption der Investmentbesteuerung: Vision und Wirklichkeit. In: NWB - Steuer- und Wirtschaftsrecht 10 (24), S. 1970-1977

[Kestens, Cauwenberge \& Christiaens, 2012] Kestens, Katrien, Philippe Van Cauwenberge \& Johan Christiaens. The Effect of the Notional Interest Deduction on the Capital Structure of Belgian SMEs. In: Environment and Planning C: Government and Policy 30 (2), S. 228-247

[King \& Fullerton, 1984] King, Mervyn A. \& Don Fullerton. The taxation of income from capital: a comparative study of the United States, the United Kingdom, Sweden, and West Germany. Chicago 1984

[Klassen, Lang \& Wolfson, 1993] Klassen, Kenneth J., Mark Lang \& Mark Wolfson. Geographic Income Shifting by Multinational Corporations in Response to Tax Rate Changes. In: Journal of Accoimting Research 31 (Supplement 1993), S. 141-173

[Klassen \& Laplante, 2012] Klassen, Kenneth J. \& Stacie K. Laplante. Are U.S. Multinational Corporations Becoming More Aggressive Income Shifters? In: Journal of Accounting Research $50(5)$, S. $1245-1285$

[Koch, 2014] Koch, Reinald. Entscheidungs- und Aufkommenswirkungen der Unternehmensbesteuerung. Behavioral responses and revenue consequences of company taxation. Göttingen 2014

[Koch, 2014] Koch, Reinald. The accuracy and explanatory power of simulated marginal tax rates. In: Entscheidungs- und Aufkommenswirkungen der Unternehmensbesteuerung. Behavioral responses and revenue consequences of company taxation. Hrsg. von Reinald Koch. Göttingen 2014, S. 142-170 
[La Porta, Lopez de Silanes \& Shleifer, 2008] La Porta, Rafael, Florencio Lopez de Silanes \& Andrei Shleifer. The Economic Consequences of Legal Origins. In: Journal of Economic Literature 46 (2), S. 285-332

[Leone \& Zanotti, 2012] Leone, Francesco \& Emiliano Zanotti. Notional Interest Deduction Regime Introduced. In: European Taxation 52 (8), S. 432-436

[Long \& Freese, 2006] Long, J. Scott \& J. Freese. Regression models for categorical dependent variables using Stata. College Station 2006

[Lübbehüsen, 2010] Lübbehüsen, Dieter. InvStG Vorbemerkung zu $\S \S 1$ ff. In: Investmentgesetz, Investmentsteuergesetz: Kommentar. Hrsg. von Hanno Berger, Kai-Uwe Steck \& Dieter Lübbehüsen. München 2010

[Markusen, 1995] Markusen, James R. The Boundaries of Multinational Enterprises and the Theory of International Trade. In: The Journal of Economic Perspectives 9 (2), S. 169-189

[McFadden, 1974] McFadden, Daniel. Conditional logit analysis of qualitative choice behavior. In: Frontiers in econometrics. Hrsg. von Paul Zarembka. New York 1974, S. 105-142

[Merlo, Riedel \& Wamser, 2015] Merlo, Valeria, Nadine Riedel \& Georg Wamser. The Impact of Thin Capitalization Rules on the Location of Multinational Firms' Foreign Affiliates. CESifo Working Paper 5449. München: CESifo 2015

[Neary, 2008] Neary, J. Peter. foreign direct investment: the OLI framework. In: The Princeton Encyclopedia of the World Economy. Hrsg. von Kenneth A. Reinert \& Ramkishen S. Rajan. Princeton 2008

[Nobes, 2000] Nobes, Christopher W. GAAP 2000. A Survey of National Accounting Rules in 53 Countries. Dezember 2000. Online abrufbar unter: http://www.iasplus.com/en/binary/ resource/gaap2000.pdf (zuletzt abgerufen am 13.08.2016) 
[OECD, 2011] OECD. Corporate Loss Utilisation through Aggressive Tax Planning. 2011. Online abrufbar unter: http://uscib.org/docs/Corporate_Loss_Utilisation_through_Aggressive_ Tax_Planning.pdf (zuletzt abgerufen am 08.01.2017)

[Oestreicher \& Hammer, 2014] Oestreicher, Andreas \& Markus Hammer. Taxation of Income from Domestic and Cross-border Collective Investment: A Qualitative and Quantitative Comparison. Cham, Heidelberg, New York, Dordrecht, London 2014

[Oestreicher, Koch u.a., 2013] Oestreicher, Andreas, Reinald Koch, Dorothea Vorndamme \& Stefan Hohls. ASSERT - Assessing the effects of reforms in taxation - a micro-simulation approach. Working Paper 14-001. Göttingen: Georg-August-Universität Göttingen September 2013

[Ohlin, Hesselborn \& Wijkman, 1977] Ohlin, Bertil, Per-Ove Hesselborn \& Per Magnus Wijkman (Hrsg.). The International Allocation of Economic Activity. London und Basingstoke 1977

[o.V., 2012] o.V. Bericht der Bund-/Länderarbeitsgruppe "Neukonzeption der Investmentbesteuerung”. Entwurf. Wiesbaden 24. Februar 2012. Online abrufbar unter: http://www.derbetrieb.de/content/pdfft,0,469318 (zuletzt abgerufen am 13. 03.2014)

[Overesch \& Wamser, 2009] Overesch, Michael \& Georg Wamser. Who Cares About Corporate Taxation? Asymmetric Tax Effects on Outbound FDI. In: The World Economy 32 (12), S. $1657-1684$

[Patzner \& Döser, 2012] Patzner, Andreas \& Achim Döser. InvG § 96. In: Handkommentar Investmentrecht: Aufsicht, Besteuerung. Hrsg. von Andreas Patzner, Achim Döser \& Ludger J. Kempf. Baden-Baden 2012

[Patzner, Döser \& Kempf, 2012] Patzner, Andreas, Achim Döser \& Ludger J. Kempf (Hrsg.). Handkommentar Investmentrecht: Aufsicht, Besteuerung. Baden-Baden 2012 
[Patzner \& Kempf, 2012] Patzner, Andreas \& Ludger J. Kempf. InvStG § 3. In: Handkommentar Investmentrecht: Aufsicht, Besteuerung. Hrsg. von Andreas Patzner, Achim Döser \& Ludger J. Kempf. Baden-Baden 2012

[Plesko, 2003] Plesko, George A. An evaluation of alternative measures of corporate tax rates. In: Journal of Accounting and Economics 35 (2), S. 201-226

[PwC, 2015] PwC. PwC Worldwide Tax Summaries. Corporate Taxes 2015/16. Juni 2015. Online abrufbar unter: http://www.pwc.com/gx/en/tax/corporate-tax/worldwide-taxsummaries/assets/pwc-worldwide-tax-summaries-corporate-2015-16.pdf (zuletzt abgerufen am 19.07.2016)

[Ramackers, 2010] Ramackers, Arnold. InvStG § 7. In: Investmentgesetz, Investmentsteuergesetz: Kommentar. Hrsg. von Hanno Berger, Kai-Uwe Steck \& Dieter Lübbehüsen. München 2010

[Ramb, 2007] Ramb, Fred. Corporate marginal tax rate, tax loss carryforwards and investment functions - empirical analysis using a large German panel data set. Discussion Paper 21/2007. Frankfurt am Main: Deutsche Bundesbank 2007

[Scheffler, 2013] Scheffler, Wolfram. Besteuerung von Unternehmen, Band III: Steuerplanung. Heidelberg, München, Landsberg, Frechen und Hamburg 2013

[Schmitz, 2010] Schmitz, Rainer. InvG § 30. In: Investmentgesetz, Investmentsteuergesetz: Kommentar. Hrsg. von Hanno Berger, Kai-Uwe Steck \& Dieter Lübbehüsen. München 2010

[Schmitz, 2010] Schmitz, Rainer. InvG Vorbemerkung zu $\S \S 30$ bis 45. In: Investmentgesetz, Investmentsteuergesetz: Kommentar. Hrsg. von Hanno Berger, Kai-Uwe Steck \& Dieter Lübbehüsen. München 2010

[Schreiber, 2012] Schreiber, Ulrich. Besteuerung der Unternehmen: Eine Einführung in Steuerrecht und Steuerwirkung. Berlin und Heidelberg 2012 
[Shevlin, 1987] Shevlin, Terry. Taxes and Off-Balance-Sheet Financing: Research and Development Limited Partnerships. In: The Accounting Review 62 (3), S. 480-509

[Shevlin, 1990] Shevlin, Terry. Estimating Corporate Marginal Tax Rates with Asymmetric Tax Treatment of Gains and Losses. In: Journal of the American Taxation Association 11 (2), S. $51-67$

[Spengel, Endres u.a., 2014] Spengel, Christoph, Dieter Endres, Katharina Finke \& Jost H. Heckemeyer. Effective Tax Levels Using the Devereux/Griffith Methodology. Techn. Ber. Project for the EU Commission (TAXUD/2013/CC/120), Final Report 2014. Mannheim: Zentrum für Europäische Wirtschaftsforschung Oktober 2014

[Spengel \& Lammersen, 2001] Spengel, Christoph \& Lothar Lammersen. Methoden zur Messung und zum Vergleich von internationalen Steuerbelastungen. In: Steuer und Wirtschaft 78 (3), S. $222-238$

[Spengel \& Zöllkau, 2012] Spengel, Christoph \& York Zöllkau. Common Corporate Tax Base $(\mathrm{CC}(\mathrm{C}) \mathrm{TB})$ and Determination of Taxable Income. An International Comparison. Berlin und Heidelberg 2012

[Destatis, 2012] Statistisches Bundesamt. Hebesätze der Realsteuern. Wiesbaden 2012. Online abrufbar unter: https://www.destatis.de/DE/Publikationen/Thematisch/FinanzenSteuern/ Steuern/Realsteuer/Realsteuervergleich.html (zuletzt abgerufen am 14.03.2014)

[Steinmüller, 2012] Steinmüller, Jens. Investmentsteuerrecht: Ende der eingeschränkten Transparenz? Entwurf eines Arbeitsgruppenberichts zur Neukonzeption. In: NWB - Steuer- und Wirtschaftsrecht $10(10)$, S. 808-819

[Swenson, 2000] Swenson, Deborah L. Transaction Type and the Effect of Taxes on the Distribution of Foreign Direct Investment in the United States. In: International Taxation and Multinational Activity. Hrsg. von James R. Hines. Chicago 2000, S. 89-112

[Tavares-Lehmann, Coelho \& Lehmann, 2012] Tavares-Lehmann, Ana Teresa, Angelo Coelho \& Frederick Lehmann. "Taxes and Foreign Direct Investment Attraction: A Literature Review “. 
In: New Policy Challenges for European Multinationals. 2012, S. 89-117. eprint: http://www. emeraldinsight.com/doi/pdf/10.1108/S1745-8862\%282012\%290000007007

[Thiems, 2013] Thiems, Stefan. Die Verwirklichung des Transparenzprinzips im deutschen und österreichischen Investmentsteuerrecht. Dissertation. Universität Ulm, Fakultät für Mathematik und Wirtschaftswissenschaften. Ulm 2013

[BEA, 2003-2013] U.S. Bureau of Economic Analysis. U.S. Direct Investment Abroad (USDIA). Washington, DC 2003-2013. Online abrufbar unter: http://www.bea.gov/internation al/di1usdop.htm (zuletzt abgerufen am 16.07.2016)

[Vorndamme, 2014] Vorndamme, Dorothea. Aufkommens-, Verteilungs- und Investitionswirkungen von Steuerreformen in Deutschland und der Europäischen Union. Dissertation. Universität Göttingen, Wirtschaftswissenschaftliche Fakultät. Göttingen 2014

[Wamser, 2011] Wamser, Georg. Foreign (in)direct investment and corporate taxation. In: Canadian Journal of Economics/Revue canadienne d'économique 44 (4), S. 1497-1524

[Wenzel, 2013] Wenzel, Alexander. InvStG § 2. In: Blümich Kommentar: Einkommensteuergesetz, Körperschaftsteuergesetz, Gewerbesteuergesetz. Hrsg. von Bernd Heuermann \& Peter Brandis. München 2013 
